Published as volume 5 in the Series B as part of the „Biodiversity and Ecology Series“

Mascha Jacob

\section{Productivity and nutrient relations of trees in deciduous forests differing in tree species diversity}

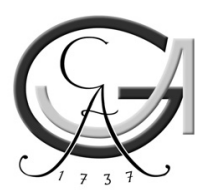

Georg-August-Universität Göttingen 2010

This work is licensed under the Creative Commons License 2.0 "by-nd", allowing you to download, distribute and print the document in a few copies for private or educational use, given that the document stays unchanged and the creator is mentioned.

You are not allowed to sell copies of the free version. 
Bibliographische Information der Deutschen Nationalbibliothek

Die Deutsche Nationalbibliothek verzeichnet diese Publikation in der Deutschen Nationalbibliographie; detaillierte bibliographische Daten sind im Internet über $<$ http://dnb.ddb.de $>$ abrufbar.

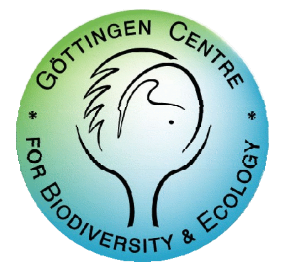

Editor Dr. Dirk Gansert

Göttingen Centre for Biodiversity and Ecology,

Georg-August-Universität Göttingen, www.biodiversitaet.gwdg.de

Dissertation zur Erlangung des Doktorgrades der

Naturwissenschaftlichen Fakultäten der

Georg-August-Universität Göttingen

vorgelegt von Mascha Jacob

Referent: Prof. Dr. Frank Thomas

Korreferent: Prof. Dr. Christoph Leuschner

Anscbrift des Autors

Mascha Jacob

e-mail: mjacob@uni-goettingen.de

Typesetting and layout: Mascha Jacob

Cover image: Mascha Jacob

DOI: http://dx.doi.org/10.3249/webdoc-2391

urn:nbn:de:gbv:7-webdoc-2391 
GÖTTINGER ZENTRUM

FÜR BIODIVERSITÄTSFORSCHUNG UND ÖKOLOGIE

- Göttingen Centre for Biodiversity And Ecology -

\title{
Productivity and nutrient relations of trees in deciduous forests differing in tree species diversity
}

\author{
Dissertation zur Erlangung des Doktorgrades der \\ Mathematisch-Naturwissenschaftlichen Fakultäten der \\ Georg-August-Universität Göttingen
}

\author{
vorgelegt von \\ Diplom - Geoökologin \\ Mascha Jacob \\ aus \\ Wilhelmshaven
}

Göttingen, Februar, 2009 
Referentin/Referent: Prof. Dr. Frank Thomas

Korreferentin/Korreferent: Prof. Dr. Christoph Leuschner

Tag der mündlichen Prüfung: 19.03.2009 


\section{Table of contents}

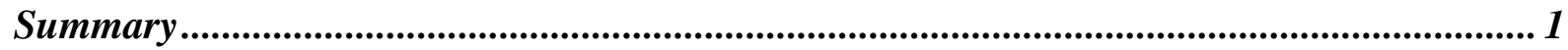

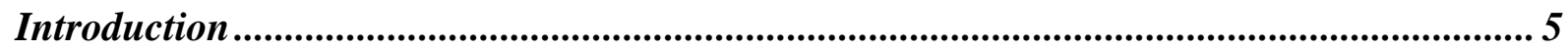

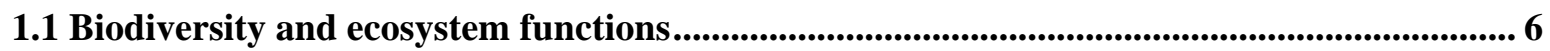

1.2 Relationship between biodiversity and ecosystems functions ............................................. 7

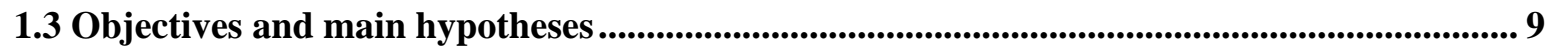

1.4 Study area - The Hainich National Park ........................................................................................... 10

1.5 Study design............................................................................................................................................. 11

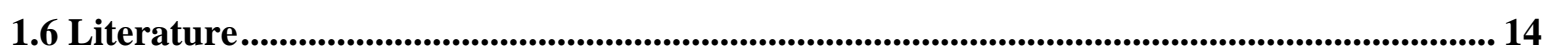

Acidity, nutrient stocks, and organic-matter content in soils of a temperate deciduous forest with different abundance of European beech (Fagus sylvatica L.) ........................................ 19

Productivity of temperate broad-leaved forest stands differing in tree species diversity...... 47

Leaf litter decomposition in temperate deciduous forest stands along a gradient of increasing tree species diversity.

Nutrient release from decomposing leaf litter of temperate deciduous forest trees along a gradient of increasing tree species diversity

Nutrient stocks of five deciduous forest tree species in monospecific and mixed species forest stands .................................................................................................................................................. 105

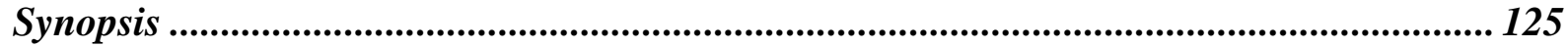

7.1 Differ monospecific stands from mixed species stands in ecosystem functions? ................ 126

7.2 Differ tree species regarding their ecosystem functions? ......................................................... 127

7.3 Differences between beech trees in pure compared to mixed species forest stands........... 131

7.4 Interactions between tree species and soil parameters ...................................................... 131

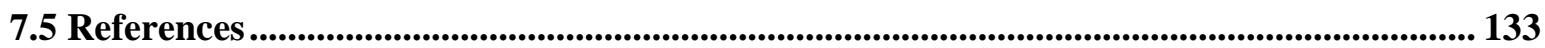

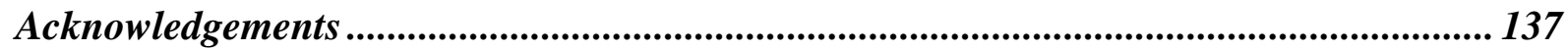

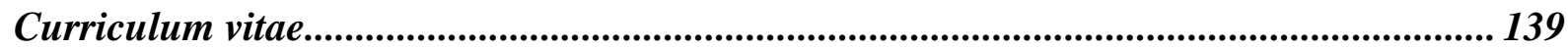





\section{Summary}

Effects of biodiversity on ecosystem functioning in forests ecosystems are of increasing interest. There is a vital debate about the influence of species numbers and plant functional traits for different ecosystem functions such as primary productivity, nutrient cycling and carbon storage. Only few studies on biodiversity effects were conducted in natural forest, despite their ecological and socioeconomic importance. Here we studied 12 forest stands in the Hainich National Park (Thuringia, Central Germany). The general objectives of this comparative study were (i) to quantify aboveground tree biomass and nutrient content, (ii) to assess total stand and species-specific productivity, and (iii) to examine decomposition rates and nutrient release patterns. The focus was to find and understand relations between tree species diversity and ecosystem functions such as productivity, decomposition and nutrient release.

Studied forest stands grew on similar soils (physical properties) and bedrock and differentiated by a gradient of increasing tree species from pure beech forest stands (Fagus sylvatica), to medium-diverse forests built by beech, ash (Fraxinus excelsior), and lime (Tilia cordata and T. platyphyllos), and to highly-diverse stands dominated by beech, ash, lime, maple (Acer pseudoplatanus and A. platanoides), and hornbeam (Carpinus betulus). Stem wood increment in 2006 and 2007 was measured using permanent measurement tapes. Leaf and fruits biomass from 2005 to 2007 were collected with litter samplers and a litterbag experiment was conducted over 22 months to obtain litter, lignin and nutrient release rates.

Total above-ground biomass decreased significantly with tree species diversity from 480 to $200 \mathrm{Mg} \mathrm{ha}^{-1}$. We found distinct differences between the main tree species of our study regarding total and seasonal production of biomass - e.g. Fraxinus exhibited the highest wood production, Fagus had higher basal area-related stem wood production than basal area-related leaf mass production and seasonal growth dynamics of Tilia apparently reacted most sensitive to actual climatic conditions. Total above-ground production did not differ significantly between the different forest stands, but exhibited a decreasing tendency with decreasing beech abundance (9.0, 8.5 and $\left.7.1 \mathrm{Mg} \mathrm{ha}^{-1}\right)$. Leaf biomass was constant for all forest stands and investigated years ranging from 3.1 to $3.9 \mathrm{Mg} \mathrm{ha}^{-1}$.

Leaf litter and lignin decomposition rates were higher in the mixed species forest stands than in pure beech stands. Correspondingly, rates of nutrient release from litter mixtures were significantly higher in the highly diverse stands. Litter decomposition of Fagus was enhanced in the mixed species stands. Among individual tree species, Fagus leaf litter exhibited slowest decomposition rates (decomposition rate constant $k=0.5$ ), whereas Fraxinus leaf litter decomposed fastest $(\mathrm{k}=2)$. The decomposition rate constants $\mathrm{k}$ were closely correlated 
with the thickness of the organic litter layer, soil $\mathrm{pH}$, soil fauna abundance and initial $\mathrm{C}: \mathrm{N}, \mathrm{Ca}$ and $\mathrm{N}$ values of leaf litter.

We found the highest nutrient foliar concentrations in Tilia $(\mathrm{N}, \mathrm{P}, \mathrm{K})$ and Fraxinus $(\mathrm{Ca}, \mathrm{K}$, $\mathrm{Mg}$ ). Beech foliage and leaf litter had the lowest nutrient concentration compared to the other deciduous tree species. Basal area-related nutrient stocks were comparable in the 'storage compartments' stem wood and branches. Species-specific differences are high within leaf litter and fruits for all nutrients. Higher basal area-related total nutrient storage of $\mathrm{K}, \mathrm{Mg}, \mathrm{Ca}$, $\mathrm{N}$, and $\mathrm{P}$ in mixed species stands compared to monospecific stands was found.

We found no evidence of complementary resource use associated with above-ground biomass production. Higher decomposition and nutrient release rates indicated a faster nutrient cycling in the mixed species stands. However, basal area-related productivity of the monospecific stands was not higher in the mixed than in the pure stands. Instead, mixed species stands revealed higher nutrients content in all tree compartments of the mixed species stands. The results suggest that at sites that allow production of broadleaf tree species with nutrient-rich, easily decomposable foliage the establishment and promotion of these species is an important silvicultural tool to counteract natural or anthropogenic soil acidification and to maintain soil productivity. In general, all ecosystem functions were strongly dependent on the characteristic physiological, morphological and architectural traits, rather than on tree species number per se. 


\section{Zusammenfassung}

Die Effekte der Biodiversität auf die Ökosystemfunktionen von Wäldern werden mit steigendem Interesse diskutiert. Ein Schwerpunkt der Debatte liegt dabei auf dem Einfluss der Artenzahlen als auch der funktionellen Gruppen auf verschiedene Ökosystemfunktionen, wie zum Beispiel der Primärproduktion, dem Nährstoffkreislauf oder dem Kohlenstoffhaushalt. In naturnahen Wäldern wurden trotz ihrer großen ökologischen und sozioökonomischen Bedeutung bisher nur wenige Studien über Biodiversitätseffekte durchgeführt. Daher haben wir in einer vergleichenden Studie zwölf Waldbestände im thüringischen Nationalpark Hainich mit der folgenden Zielsetzung untersucht: (1) die Quantifizierung der oberirdischen Biomasse und der Nährstoffgehalte der Bäume, (2) die Bestimmung der Bestandes- und der artspezifischen Produktivität und (3) die Zersetzungsraten und Nährstofffreisetzungsraten von Blättern zu ermitteln. Der Schwerpunkt lag dabei auf dem Verständnis der Beziehung zwischen der Baumartenvielfalt und den einzelnen Ökosystemfunktionen, wie der Produktivität, der Streuzersetzung und der Nährstofffreisetzung.

Die untersuchten Waldbestände haben vergleichbare physikalische Bodeneigenschaften, gleiches Ausgangsgestein und unterscheiden sich durch einen Gradienten mit zunehmender Baumartendiversität von reinen Buchenbeständen (Fagus sylvatica), über mittel-diversen Beständen aus Buche, Esche (Fraxinus excelsior) und Linde (Tilia cordata und $T$. platyphyllos) zu hoch-diversen Beständen aus Buche, Esche, Linde, Ahorn (Acer pseudoplatanus und $A$. platanoides) und Hainbuche (Carpinus betulus). Stammholzzuwächse wurden ab dem Jahr 2006 mit dauerhaft installierten Messbändern aufgenommen. Die Blatt und Fruchtmassen wurden von 2005 bis 2007 mit Streusammlern aufgefangen und gewogen und mittels eines Streuzersetzungsexperiments ('litterbag experiment') wurden 22 Monate lang die Abbauraten der Streu, des Ligningehaltes in der Streu und die Nährstofffreisetzungsraten bestimmt.

Die gesamte oberirdische Biomasse ist signifikant mit der Baumartendiversität von 480 auf $200 \mathrm{Mg} \mathrm{ha}^{-1}$ gesunken. Wir haben deutliche Unterschiede zwischen den Hauptbaumarten unserer Studie in dem saisonalen Zuwachsverhalten erkennen können - so hatte Fraxinus beispielsweise die höchste Holzproduktion, Fagus eine, auf die Basalfläche bezogen größere Stammholz- als Blattmasseproduktion und die saisonale Zuwachsdynamik von Tilia scheint am sensitivsten mit der aktuellen Witterung zusammenzuhängen. Die gesamte oberirdische Produktion hat sich zwischen den verschiedenen Waldbeständen nicht signifikant unterschieden, aber eine abnehmende Tendenz mit abnehmender Buchenhäufigkeit $(9,0$; 8,5 und 7,1 $\mathrm{Mg} \mathrm{ha}^{-1}$ ) ist erkennbar. Die Blattbiomasse war in allen Waldbeständen und in allen Untersuchungsjahren konstant (zwischen 3,1 und 3,9 $\mathrm{Mg} \mathrm{ha}^{-1}$ ). 
Die Streu- und Ligninzersetzungsraten waren höher in den Mischbeständen als in den reinen Buchenbeständen. Entsprechend waren auch die Nährstofffreisetzungsraten signifikant höher in den hoch-diversen Beständen. Die Streuzersetzung von Fagus war in den Mischbeständen deutlich erhöht. Bei den einzelnen Baumarten hatte die Buchenstreu allerdings die langsamste Streuzersetzungsrate ('decomposition rate constant' $k=0.5$ ), wohingegen die Eschenstreu als schnellste zersetzt wurde $(k=2)$. Die k-Werte der Zersetzungsraten waren eng mit der Mächtigkeit der organischen Auflage, dem pH-Wert des Oberbodens, der Anzahl der Bodenfauna und den Anfangsgehalten von $\mathrm{C}: \mathrm{N}, \mathrm{Ca}$ und $\mathrm{N}$ in der Streu korreliert.

Wir haben die höchsten Nährstoffkonzentrationen in frischen Blättern von Tilia $(N, P, K)$ und Fraxinus ( $\mathrm{Ca}, \mathrm{K}, \mathrm{Mg}$ ) gefunden. Buchenlaub und Buchenstreu hatte die geringsten Nährstoffkonzentrationen verglichen mit denen anderer Laubbaumarten. Auf die Basalfläche bezogene Nährstoffvorräte waren in den ,Speicherkompartimenten' Holz und Ästen vergleichbar hoch. Artspezifische Unterschiede sind bei allen Nährstoffen in der Streu und in den Früchten vorhanden. Höhere basalflächenbezogene Nährstoffvorräte von $\mathrm{K}, \mathrm{Mg}, \mathrm{Ca}, \mathrm{N}$ und $\mathrm{P}$ konnten in den Mischbeständen verglichen mit den reinen Buchenbeständen nachgewiesen werden.

Wir haben keinen Hinweis auf komplementären Ressourcenverbrauch in Verbindung mit der oberirdischen Biomasseproduktion gefunden. Höhere Zersetzungs- und Nährstofffreisetzungsraten weisen auf einen höheren Nährstoffkreislauf in den Mischbeständen hin. Jedoch ist die Produktivität bezogen auf die Basalfläche der Bäume in den Mischbeständen nicht höher verglichen mit den reinen Buchenbeständen. Wir haben sogar höhere Nährstoffgehalte in allen Baumkompartimenten in den Mischbeständen gefunden. Die Ergebnisse zeigen, dass vor allem für Standorte, die für den Anbau von Laubbaumarten mit ihrer nährstoffreichen und leicht zersetzbaren Streu geeignet sind, mit diesen Arten ein wichtiges forstwirtschaftliches Instrument gegeben ist, um natürlicher oder anthropogener Bodenversäuerung entgegen zu wirken und die Produktivität der Böden zu erhalten. Im Allgemeinen waren alle Ökosystemfunktionen stark abhängig von den für die jeweilige Baumart charakteristischen physiologischen, morphologischen und architektonischen Eigenschaften als nur von der Baumartenanzahl allein. 


\section{Chapter \\ 1}

Introduction 


\subsection{Biodiversity and ecosystem functions}

Biodiversity or biological diversity is defined as "the variability among living organisms from all sources including, inter alia, terrestrial, marine and other aquatic ecosystems and the ecological complexes of which they are part; this includes diversity within species, between species and of ecosystems" (CBD 2006). Biodiversity can also be described in terms of numbers (e.g. plant species, genes, ecosystems), the evenness of their distribution, the differences in their functional traits and the corresponding interactions (Hooper et al. 2005). During the past two decades, there was a vital debate about the effects of biodiversity on ecosystem functions such as primary productivity, nutrient cycling and carbon storage in managed and near-natural ecosystems (e.g., Loreau et al. 2002, Hooper et al. 2005, Hector et al. 2007).

Effects of biodiversity on ecosystem functioning were mainly studied with experiments in even-aged, short-lived systems such as grasslands. These experiments artificially create gradients in grassland plant diversity (Leuschner et al. 2009). Forest ecosystems with a high longevity of dominant trees and a complex stand structure were largely excluded from biodiversity experiments, despite their ecological and socioeconomic importance (SchererLorenzen et al. 2007). Most studies comparing species-poor and species-rich stands contrasted plots with one and two tree species (cf. Cannell et al. 1992). Only during the past decade, a few large-scale experimental designs with more tree species were established in forest biomes worldwide: e.g. in a neotropical forest in Panama (1-6 tree species), a palaeotropical forest in Malaysian Borneo (1-16 tree species), a boreal forest in Finland (1-5 tree species), and a mixed temperate forest in Germany (1-6 tree species) (SchererLorenzen et al. 2005a). The temperate forest experiment, BIOTREE, was planted in 2003 and is situated in Central Germany, Thuringia, close to the Hainich National Park. Response variables in this experiment also focus on productivity and biogeochemical cycles (SchererLorenzen et al. 2007).

Such experiments with artificially created gradients of even-aged and long-lived plants are important to detect underlying mechanisms of relationships between diversity and ecosystem processes, although they have shortcomings to transfer these results to multi-aged mature forest stands with its complex stand structure (Leuschner et al. 2009). Therefore, observational studies that compare diversity and ecosystem processes in different existing forest stands (e.g. Caspersen and Pacala 2001, Vilà et al. 2003, Vilà et al. 2007) are needed to complement manipulative experiments. Observational studies in mixed forests have the advantage to compare adult trees of stands with near-natural structure, intact food web structures and nutrient contents in biomass at a quasi steady state (Leuschner et al. 2009). $-6-$ 
However, covarying factors such as environmental conditions, land use history, or management may obscure potential effects of biodiversity on ecosystem processes and site conditions therefore have to be very similar (Mund and Schulze 2005, Vilà et al. 2005).

Due to the Ice Ages and geological barriers (the Alps), the tree species diversity of CentralEuropean forests is much lower than in the temperate zones of other continents. European beech (Fagus sylvatica L.) would dominate natural forest vegetation in Central Europe without anthropogenic interference, except for the upper montane regions (e.g. Ellenberg 1996). Because of climate change, which is expected to result in weather extremes and lowered precipitation in summer, silvicultural measures are undertaken to convert monospecific into mixed stands (e.g. BMVEL 2001) to strengthen the stability and resilience of the forest stands (cf. Scherer-Lorenzen et al. 2005b). In beech forests, management programs aim at increasing the portion of other broad-leaved tree species such as ash (Fraxinus excelsior L.), lime (Tilia spp.), maple (Acer spp.) and hornbeam (Carpinus betulus L.). However, the consequences of this conversion for productivity, biotic interactions and the fluxes of energy and matter as well as for ecosystem goods and services used by man are insufficiently known.

\subsection{Relationship between biodiversity and ecosystems functions}

\section{Biomass and productivity}

In synthetic grassland communities, mostly positive effects of plant species diversity on plant biomass production have been found (e.g. Tilman et al. 1997, Hector et al. 1999, Caldeira et al. 2001, van Ruijven and Berendse 2003, Roscher et al. 2005). In theory, increased biomass production in stands that are more diverse in plant species or plant functional groups may be a consequence of positive interactions among the species or may result from complementarity in resource use, e.g., increased depletion of light, water or nutrients by coexisting plant species (e.g. Hooper and Vitousek 1997). Positive mixture effect with increasing productivity of one or two of the investigated tree species compared to the corresponding pure stands, so called overyielding, can be explained with complementarity in resource use.

In forest ecosystems, observational studies addressing the biodiversity-functioning relation started only recently and have not yet found strong evidence for consistent mixture effects on productivity (e.g. Ewel et al. 1991, Cannell et al. 1992, Wright 1996, Vilà et al. 2003, SchererLorenzen et al. 2005b). A survey in Mediterranean-type forests across a broad range of environmental conditions found significantly higher wood production with increasing local tree species richness and no effect within functional species richness (Vilà et al. 2007). A 
previous study in this region found no significant effect of tree species richness on wood production, when environmental factors, such as climate, bedrock types, and radiation were included in the analysis (Vilà et al. 2003). For temperate North American forests, Casperson and Pacala (2001) reported an asymptotic increase in wood production with increasing tree species richness. A study on productivity - diversity relations of forests worldwide failed to yield relationships between tree species number and production of above-ground tree biomass (Enquist and Niklas 2001). Our study will show further results on the biodiversityrichness relation in temperate forests.

Foresters in European countries have conducted comparative studies mainly with pure and two-species stands on the effects of species mixtures on wood production for nearly a century (e.g. Cannell et al. 1992, Oltshoorn et al. 1999, Pretzsch 2005). Studies in temperate forests revealed that the productivity of mixed stands can decrease or increase by up to $30 \%$ compared to monospecies stands, depending on the specific physiology and growth potential of the species (Pretzsch 2005). Positive mixture effect with increasing productivity of one or two of the investigated tree species compared to the corresponding pure stands, so called overyielding, could be explained with complementarity in resource use (similar to results in grasslands) and decreased interspecific concurrence (e.g. Kennel 1965, Assmann 1970, Brown 1992, Morgan et al. 1992). No or negative effects of mixing species, due to competitive interactions where the inferior competitor can only be sustained by silvicultural interference are also for long known by foresters (e.g. Smith and Long 1992, Yanai 1992, Pretzsch 2005).

\section{Decomposition, nutrient release and mineralization}

Plant species composition affects ecosystem nutrient cycling through plant-nutrient uptake and use, amount and chemical composition of the leaf litter, rhizosphere interactions and microenvironmental changes (Hättenschwiler et al. 2005, Hättenschwiler and Gasser 2005). Grassland experiments mainly focused on primary productivity, ecosystem nutrient retention and to a lower extent on decomposition and nutrient cycling (e.g. Hooper et al. 2005, Spehn et al. 2005). About 40 studies on the relationship between tree species diversity and litter decomposition and/or $\mathrm{N}$ mineralization showed no coherent pattern (Schmid et al. 2001, Balvanera et al. 2006, Roscher et al. 2008).

There also seems to be no general relation between biodiversity and nutrient cycling in boreal and temperate forests (Rothe and Binkley 2001), although niche partitioning and complementarity models would lead one to expect so (Tilman 1999, Chesson et al. 2002). Again, some mixtures show, for example, enhanced nutrient uptake in comparison to the 
corresponding monospecific stands, and others do not. Diversity effects on decomposition and nutrient mineralization are known for some litter mixtures due to inter- and intraspecific variations in litter quality (Hättenschwiler 2005, Hättenschwiler and Gasser 2005). However, the relationship between litter species diversity and process rate does not yet appear to be predictable, and species identity within a mixture seems to be more important than the mere number of species (Scherer-Lorenzen et al. 2005, Hättenschwiler et al. 2005). Generally, in temperate forest ecosystems, the existence of species-specific traits of the trees seem to render the effects of litter mixing and effects on the decomposition rates are hardly predictable (Hättenschwiler et al. 2005, Madritch and Cardinale 2007, De Deyn et al. 2008).

\subsection{Objectives and main hypotheses}

This study was conducted in the framework of the Graduiertenkolleg 1086 about "The role of biodiversity for biogeochemical cycles and biotic interactions in temperate deciduous forests", which includes $14 \mathrm{PhD}$-students working in the same study area. The main project has been divided into three parts: A - Biodiversity analysis and biotic interactions, B Biogeochemical cycles, and C - Synthesis.

I investigated the role of tree species diversity in forest stands for the following ecosystem functions: productivity, litter decomposition and nutrient release (Project B1). The general objectives of this study are:

- to quantify aboveground tree biomass

- to assess stem wood production, leaf production and fruit production

- to investigate temporal stem growth patterns

- to examine decomposition rates and nutrient release patterns

- to quantify nutrient stocks in different tree compartments

In particular, we examined the following hypothesis:

(1) Tree litter composition is one pivotal factor to govern variability of surface soil acidity and nutrient status, and of the amount and distribution of soil organic matter (Chapter 2).

(2) Productivity of mixed stands is higher than that of pure beech stands because tree species in mixed stands differ in their seasonal growth dynamics (Chapter 3).

(3) Productivity of European beech is higher in mixed stands than in pure beech stands (Chapter 3).

(4) in multi-specific stands, the bulk litter and the litter of the individual tree species is faster decomposed than in pure beech stands (Chapter 4,5 ) 
(5) The nutrient release rates of each diversity level and of all single tree species are higher in the multi-specific stands compared to monospecific beech stands (Chapter 5)

(6) Total nutrient amounts in monospecific beech stands are higher than in the mixed stands (Chapter 6)

(7) basal area-related beech nutrient stocks are highest in the mixed species stands (Chapter 6)

\subsection{Study area - The Hainich National Park}

We conducted the study in the Hainich National Park, Thuringia, Central Germany - an outstanding example of a highly diverse European temperate broad-leaved forest. All research plots are situated at an elevation of about $350 \mathrm{~m}$ a.s.l. near the village of Weberstedt $\left(51^{\circ} 06^{\prime} \mathrm{N}, 10^{\circ} 31^{\prime} \mathrm{E}\right)$. The mean annual temperature at the Weberstedt meteorological station is $7.5^{\circ} \mathrm{C}$ and the mean annual precipitation is $670 \mathrm{~mm}$. Soils are Luvisols with stagnic properties, developed from Pleistocene loess and underlain by limestone (Triassic Upper Muschelkalk formation) (FAO 2006). They are characterized by high silt contents (about 75\%), and have a loess cover of at least $60 \mathrm{~cm}$ (Guckland et al. 2009). Dominant forest communities are the Galio-Fagetum, the Hordelymo-Fagetum, and the Stellario-Carpinetum (Mölder et al. 2008).

Mean stand age of canopy trees ranged between 90 and 150 years (Schmidt et al. 2008). All research sites have been permanently covered by deciduous forest for at least 200 years. Historic forest utilization from the middle of the $19^{\text {th }}$ century until the early $20^{\text {th }}$ century included initial coppice with standards system (Mittelwald), and later high forest (Hochwald) and the multiple aged forest system Plenterwald (Schmidt et al. 2009). For the past four decades, the studied stands could develop a near-natural structure, since there was no more harvesting and thinning when the military training area was founded in 1964 and the national park was established in 1997 (Mölder et al. 2008). 


\subsection{Study design}

Three stand types differing in the diversity level (DL) of tree genera with increasing abundance of beech were selected in the north-eastern part of the national park:

- a stand type with European beech (Fagus sylvatica L.) as the predominating tree species (DL 1);

- a stand type mainly consisting of beech, lime (Tilia cordata Mill. and T. platyphyllos Scop.) and ash (Fraxinus excelsior L.) (DL 2); and

- a stand type with beech, lime, ash, hornbeam (Carpinus betulus L.) and maple (Acer pseudoplatanus L. and A. platanoides L.) as the dominant tree taxa (DL 3).

Other tree species with less than $5 \%$ of total plot basal area in our stands are Quercus robur, Acer campestre, Prunus avium, Ulmus glabra, and Sorbus torminalis. Quercus petraea occurs on a single plot with $10 \%$ of total plot basal area.

The study plots were located within a radius of about $4 \mathrm{~km}$, and were comparable with respect to slope, physical soil conditions and climate. At each diversity level (stand type), three plots $(\mathrm{a}, \mathrm{b}, \mathrm{c})$ of $50 \mathrm{~m} \times 50 \mathrm{~m}$ size were selected for study, and fenced to exclude wild boar and game. Within each plot, three 30-m transects with two randomly selected subplots $(6 \mathrm{~m} \times 5 \mathrm{~m})$ for vegetation studies and zoological investigations were installed. Detailed description on selection criteria for all plots and the study design are shown in Leuschner et al. (2009) and chapter 2.

In this study we investigated the following parameters:

\section{- Stand structure}

All trees with a diameter at breast height $(d b h)$ of at least $7 \mathrm{~cm}$ were recorded in spring and summer 2005. In winter 2005/2006, tree height of all single trees was measured using a Vertex sonic clinometer and transponder (Haglöf Sweden AB, Långsele, Sweden). Crown area was determined by 8-point canopy projection with a sighting tube equipped with a $45^{\circ}$ mirror (constructed in the Department of Remote Sensing, University of Göttingen, Germany) from all members of the Graduiertenkolleg (GRK) 1086.

\section{- Biomass and productivity}

The production of leaf and fruit biomass was determined on the basis of litter traps. On each plot, 15 litter collectors (aperture: $0.29 \mathrm{~m}^{2}$ ) were arranged at a minimum distance of $2 \mathrm{~m}$ along the three $30-\mathrm{m}$ transects (five collectors per transect). Collectors were emptied from the beginning of September to the end of December 2005 - 2007. From August 2005 to 


\section{Chapter 1}

December 2007, stem diameter increment was measured in about 900 trees with different dbh-classes $(7-20,20-40,40-60,>60 \mathrm{~cm})$ using increment measurement tapes (D1 permanent measurement tape, UP, Cottbus, Germany). Annual wood production at the plot level (in $\mathrm{Mg} \mathrm{ha}^{-1} \mathrm{a}^{-1}$ ) was calculated from the relative annual increment of wood biomass of all tree species present (Chapter 3).

\section{- Decomposition}

To determine decomposition rates of single tree species litter and stand-characteristic litter mixtures, a litterbag experiment was set up in November 2005 for two years (Chapter 4, 5).

\section{- Nutrient release}

Lignin was measured in all fresh leaf samples and subsamples of tree cores and leaf litter from the main tree species (all from 2006), as well as in litterbag samples from mono and mixed litterbags. Mono litterbags contained only tree species litter of Fagus, Fraxinus, Tilia, Carpinus, Acer platanoides and Acer pseudoplatanus. Mixed litterbags represent standspecific tree litter mixtures. The bulk of the samples was analysed for lignin concentration using near-infrared spectroscopy (NIRS) and acetylbromide method (Chapter 4). Other samples of monospecific and mixed species litterbags were used to determine nutrient release rates.

\section{- Nutrient stocks}

Nutrient concentrations of $\mathrm{N}, \mathrm{P}, \mathrm{S}, \mathrm{K}, \mathrm{Ca}, \mathrm{Mg}$ in samples of green leaves, leaf litter, fruits wood cores and stem bark were measured. All samples were taken in 2006. Nutrient stocks were calculated as nutrient concentration $\mathrm{x}$ biomass of tree compartment (Chapter 6 ). 


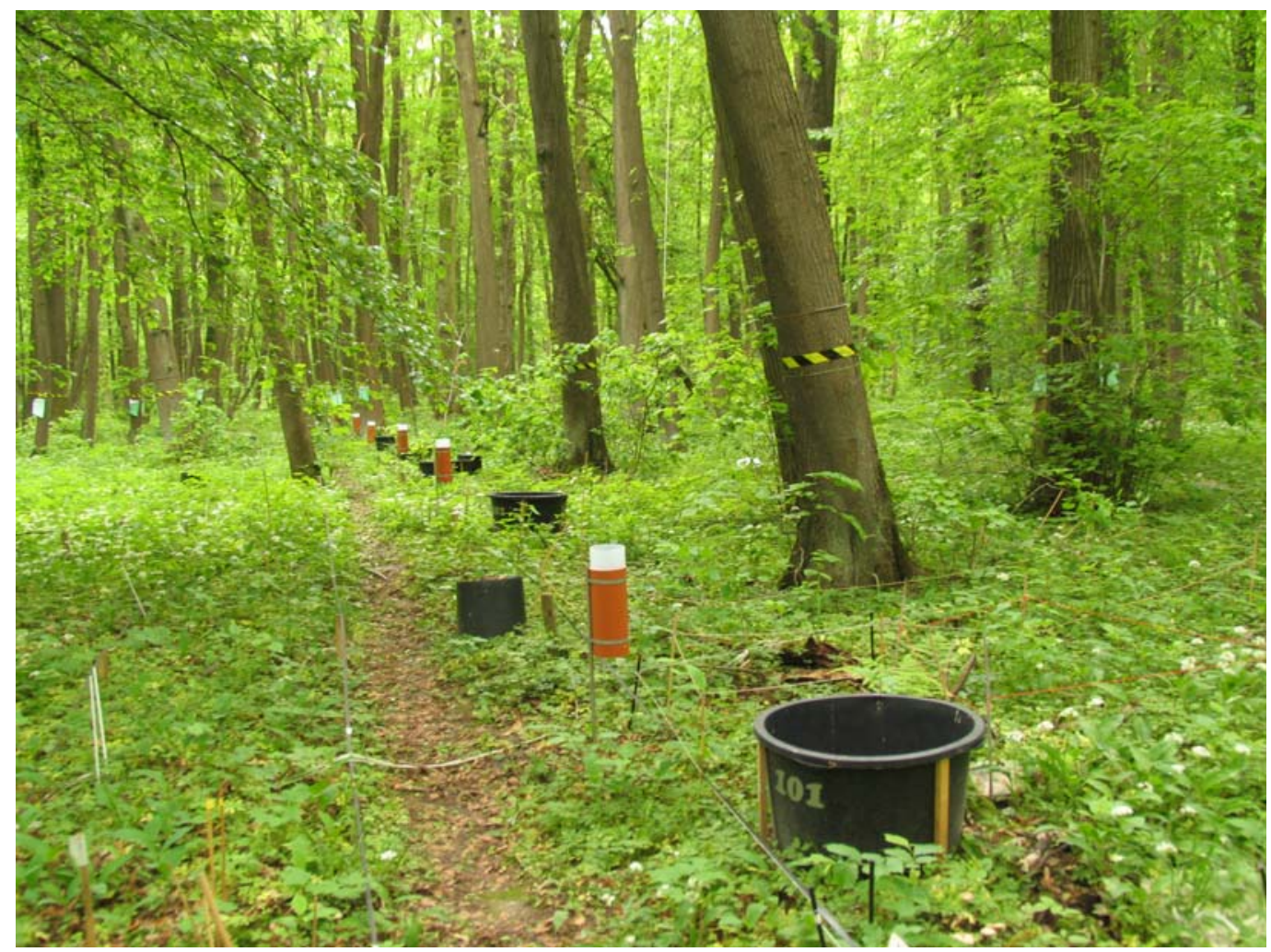

Transect with leaf litter samplers and rain gauge in a highly diverse forest stand (Foto: M. Jacob). 


\subsection{Literature}

Assmann E, 1970. The Principles of Forest Yield study: Studies in the Organic Production, Structure, Increment and Yield of Forest Stands. Pergamon Press, Oxford etc. 506 pp.

Balvanera P, Pfisterer AB, Buchmann N, He J-S, Nakashizuka T, Raffaelli D, Schmid B, 2006. Quantifying the evidence for biodiversity effects on ecosystem functioning and services. Ecology Letters 9: 1146-1156.

BMVEL (Bundesministerium für Verbraucherschutz, Ernährung und Landwirtschaft), ed., 2001. Gesamtwaldbericht der Bundesregierung. BMVEL, Bonn.

Brown AFH, 1992. Functioning of mixed-species stands at Gisburn, N.W. England. In: Cannell MGR, Malcolm DC, Robertson PA (eds.). The ecology of mixed-species stands of trees. Blackwell, Oxford, pp. 125-150.

Caldeira MC, Ryel RJ, Lawton JH, Pereira JS, 2001. Mechanisms of positive biodiversityproduction relationships: insights provided by $\delta^{13} \mathrm{C}$ analysis in experimental Mediterranean grassland plots. Ecology Letters 4: 439-443.

Cannell MGR, Malcolm DC, Robertson PA (eds.), 1992. The ecology of mixed-species stands of trees. Blackwell, Oxford.

Caspersen JP, Pacala SW, 2001. Successional diversity and forest ecosystem function. Ecological Research 16: 895-903.

CBD, 2006. Global Biodiversity Outlook 2, Convention on biological diversity, http://www.biodiv.org/GB02.

Chesson P, Pacala S, Neuhauser C, 2002. Environmental niches and ecosystem functioning. In: Kinzig AP, Pacala SW, Tilman D (eds.). The functional consequences of biodiversity. Empirical progress and theoretical extensions. Princeton Univ. Press, Princeton, 213-245.

De Deyn GB, Cornelissen JHC, Bardgett RD, 2008. Plant functional traits and soil carbon sequestration in contrasting biomes. Ecol Letters 11:516-531.

Ellenberg H, 1996. Vegetation Mitteleuropas mit den Alpen, 5th edn. Ulmer, Stuttgart.

Enquist BJ, Niklas KJ, 2001. Invariant scaling relations across tree-dominated communities. Nature 410: 655-660. 
Ewel JJ, Mazzarino MJ, Berish CW, 1991. Tropical soil fertility changes under monocultures and successional communities of different structure. Ecological Applications 1: 289-302.

Guckland A, Jacob M, Flessa H, Thomas FM, Leuschner C, 2009. Acidity, nutrient stocks, and organic-matter content in soils of a temperate deciduous forest with different abundance of European beech (Fagus sylvatica L.). J Plant Nutr Soil Sci 172:200-511.

Hättenschwiler S, 2005. Effects of tree species diversity on litter quality and decomposition. In: Scherer-Lorenzen M, Körner Ch, Schulze ED, eds. Forest diversity and function temperate and boreal systems. Ecological Studies 176. Springer, Berlin. pp 149-164.

Hättenschwiler S, Tiunov AV, Scheu S, 2005. Biodiversity and litter decomposition in terrestrial ecosystems. Annu Rev Ecol Evol Syst 36:191-218.

Hättenschwiler S, Gasser P, 2005. Soil animals alter plant litter diversity effects on decomposition. PNAS 102:1519-1524.

Hector A, Joshi J, Scherer-Lorenzen M, Schmid B, Spehn EM, Wacker L, Weilenmann M, Bazeley-White E, Beierkuhnlein C, Caldeira MC, Dimitrakopoulos PG, Finn JA, HussDanell K, Jumpponen A, Leadley PW, Loreau M, Mulder CHP, Neßhöver C, Palmborg C, Read DJ, Siamantziouras ASD, Terry C, Troumbis AY, 2007. Plant diversity and productivity experiments in European grasslands. Science 286:1123-1127.

Hector A, Schmid B, Beierkuhnlein C, Caldeira MC, Diemer M, Dimitrakopoulos PG, Finn JA, Freitas H, Giller PS, Good J, Harris R, Högberg P, Huss-Danell K, Joshi J, Jumpponen A, Körner C, Leadley PW, Loreau M, Minns A, Mulder CPH, O'Donovan G, Otway SJ, Pereira JS, Prinz A, Read DJ, Scherer-Lorenzen M, Schulze ED, Siamantziouras ASD, Spehn EM, Terry AC, Troumbis AY, Woodward FI, Yachi S, Lawton JH, 1999. Plant diversity and productivity experiments in European grasslands. Science 286:1123-1127.

Hooper DU, Chapin FS, Ewel JJ, Hector A, Inchausti P, Lavorel S, Lawton JH, Lodge DM, Loreau M, Naeem S, Schmid B, Setälä H, Symstad AJ, Vandermeer J, Wardle DA, 2005. Effects of biodiversity on ecosystem functioning: A consensus of current knowledge. Ecological Monographs 75:3-35.

Hooper DU, Vitousek PM, 1997. The effects of plant composition and diversity on ecosystem processes. Science 277:1302-1305.

Kennel, R. 1965. Untersuchungen über die Leistung von Fichte und Buche im Rein- und Mischbestand. Allgemeine Forst- und Jagdzeitung 136:149-161; 173-189. 


\section{Chapter 1}

Leuschner C, Jungkunst HF, Fleck S, 2009. Functional role of forest diversity: pros and cons of synthetic stands and across-site comparisons in established forests. Basic Appl Ecol 10, 1-9.

Loreau M, Naeem S, Inchausti P, 2002. Perspectives and challenges. In: Loreau M, Naeem $\mathrm{S}$, Inchausti $\mathrm{P}$, eds. Biodiversity and ecosystem functioning - Synthesis and perspectives. Oxford: Blackwell Oxford, pp 237-242.

Madritch MD, Cardinale BJ, 2007. Impacts of tree species diversity on litter decomposition in northern temperate forests of Wisconsin, USA: a multi-site experiment along a latitudinal gradient. Plant Soil 292:147-159.

Mölder A, Bernhardt-Römermann M, Schmidt W, 2008. Herb-layer diversity in deciduous forests: Raised by tree richness or beaten by beech? For Ecol Manage 256:272-281.

Morgan JL, Campbell JM, Malcolm DC, 1992. Nitrogen relations of mixed-species stands on oligotrophic soils. In: Cannell MGR, Malcolm DC, Robertson PA (eds.) The ecology of mixed-species stands of trees. Blackwell, London, pp. 65-85.

Mund M, Schulze ED, 2005. Silviculture and its interactions with biodiversity and the carbon balance of forest soils. In: Scherer-Lorenzen M, Körner Ch, Schulze ED, eds. Forest diversity and function - temperate and boreal systems. Ecological Studies 176. Springer, Berlin, pp 185-210.

Olsthoorn AFM, Bartelink HH, Gardiner JJ, Pretzsch H, Hekhuis HJ, Franc A, 1999. Management of mixed-species forest: silviculture and economics. IBN Scient. Contrib. 15: 1-389.

Roscher C, Temperton VM, Scherer-Lorenzen M, Schmitz M, Schumacher J, Schmid B, Buchmann N, Weisser WW, Schulze ED, 2005. Overyielding in experimental grassland communities - irrespective of species pool or spatial scale. Ecology Letters 8: 419-429.

Roscher C, Thein S, Schmid B, Scherer-Lorenzen M, 2008. Complementary nitrogen use among potentially dominant species in a biodiversity experiment varies between two years. Journal of Ecology 96: 477-488.

Rothe A, Binkley D, 2001. Nutritional interactions in mixed species forests: a synthesis. Canadian Journal of Forest Research 31: 1855-1870. 
Pretzsch H, 2005. Diversity and productivity in forests: evidence from long-term experimental plots. In: Scherer-Lorenzen M, Körner Ch, Schulze ED, eds. Forest diversity and function temperate and boreal systems. Ecological Studies 176. Berlin: Springer Berlin. pp 41-64.

Scherer-Lorenzen M, Potvin C, Koricheva J, Schmid B, Hector A, Bornik Z, Reynolds G and Schulze ED, 2005a. The design of experimental tree plantations for functional biodiversity research. In: Scherer-Lorenzen M, Körner Ch, Schulze ED, eds. Forest diversity and function - temperate and boreal systems. Ecological Studies 176. Springer, Berlin, pp 347-376.

Scherer-Lorenzen M, Körner C, Schulze ED, 2005b. The functional significance of forest diversity: a synthesis. In: Scherer-Lorenzen M, Körner Ch, Schulze ED, eds. Forest diversity and function - temperate and boreal systems. Ecological Studies 176. Springer, Berlin, pp 377-389.

Scherer-Lorenzen M, Schulze ED, Don A, Schumacher J, Weller E, 2007. Exploring the functional significance of forest diversity: A new long-term experiment with temperate tree species (BIOTREE). Perspectives in Plant Ecology, Evolution and Systematics 9, 53-70

Schmid B, Joshi J, Schläpfer F, 2001. Empirical evidence for biodiversity-ecosystem functioning relationships. In: Kinzig AP, Pacala SW, Tilman D (eds.) The functional consequences of biodiversity: empirical progress and theoretical extensions. Monographs in Population Biology 33, Princeton University Press, Princeton and Oxford, pp. 120-150.

Schmidt I, Leuschner C, Mölder A, Schmidt W, 2009. Structure and composition of the seed bank in monospecific and tree species-rich temperate broad-leaved forests. Forest Ecology and Management, 257: 695-702.

Smith FW, Long JN, 1992. A comparison of stemwood production in monocultures and mixtures of Pinus contorta var. latifolia and Abies lasiocarpa. In: Cannell MGR, Malcolm DC, Robertson PA (eds.) The ecology of mixed-species stands of trees. Blackwell, London, pp. 87-98.

Spehn EM, Hector A, Joshi J, Scherer-Lorenzen M, Schmid B, Bazeley-White E, Beierkuhnlein C, Caldeira MC, Diemer M, Dimitrakopoulos PG, Finn JA, Freitas H, Giller PS, Good J, Harris R, Högberg P, Huss-Danell K, Jumpponen A, Koricheva J, Leadley PW, Loreau M, Minns A, Mulder CPH, O'Donovan G, Otway SJ, Palmborg C, Pereira JS, Pfisterer AB, Prinz A, Read DJ, Schulze ED, Siamantziouras ASD, Terry AC, Troumbis AY, Woodward FI, Yachi S, Lawton JH, 2005. Ecosystem effects of biodiversity manipulations in European grasslands. Ecological Monographs 75: 37-63. 


\section{Chapter 1}

Tilman D, Knops J, Wedin D, Reich P, Ritchie M, Sieman E, 1997. The influence of functional diversity and composition on ecosystem processes. Science 277:1300-1302.

Tilman D, 1999. The ecological consequences of changes in biodiversity: a search for general principles. Ecology 80:1455-1474

Van Ruijven J, Berendse F, 2003. Positive effects of plant species diversity on productivity in the absence of legumes. Ecology Letters 6:170-175.

Vilà M, Vayreda J, Gracia C, Ibáñez JJ, 2003. Does tree diversity increase wood production in pine forests? Oecologia 135: 299-303.

Vilà M, Inchausti P, Vayreda J, Barrantes O, Gracia C, Ibáñez JJ, Mata T, 2005. Confounding factors in the observed productivity-diversity relationship in forests. In: Scherer-Lorenzen M, Körner Ch, Schulze ED, eds. Forest diversity and function temperate and boreal systems. Ecological Studies 176. Springer, Berlin, pp 65-86.

Vilà M, Vayreda J, Comas L, Ibáñez JJ, Mata T, Obón B, 2007. Species richness and wood production: a positive association in Mediterranean forests. Ecology Letters 10: 241-250.

Wright J, 1996. Plant species diversity and ecosystem functioning in tropical forests. In: Orians GH, Dirzo A, Cushman JH (eds.) Biodiversity and ecosystem processes in tropical forests. Ecological Studies Vol. 122. Springer, Berlin. pp. 11-31.

Yanai RD, 1992. Competitive interactions between Norway spruce and Scots pine at Gisburn Forest, NW England. Forestry 65: 435-451. 


\section{Chapter}

2

Acidity, nutrient stocks, and organic-matter content in soils of a temperate deciduous forest with different abundance of European beech (Fagus sylvatica L.)

Anja Guckland, Mascha Jacob, Heiner Flessa, Frank M Thomas, Christoph Leuschner 


\subsection{Abstract}

The production and composition of leaf litter, soil acidity, exchangeable nutrients, and the amount and distribution of soil organic matter were analyzed in a broad-leaved mixed forest on loess over limestone in Central Germany. The study aimed at determining the current variability of surface soil acidification and nutrient status, and at identifying and evaluating the main factors that contributed to the variability of these soil properties along a gradient of decreasing predominance of European beech (Fagus sylvatica L.) and increasing tree species diversity. Analyses were carried out in a) mature monospecific stands with a predominance of beech ( $\mathrm{DL} 1$ ), b) mature stands dominated by three deciduous tree species (DL 2: beech, ash (Fraxinus excelsior L.), lime (Tilia cordata Mill. and/or T. platyphyllos Scop.)), and c) mature stands dominated by five deciduous tree species (DL 3: beech, ash, lime, hornbeam (Carpinus betulus L.), maple (Acer pseudoplatanus L. and/or A. platanoides L.)).

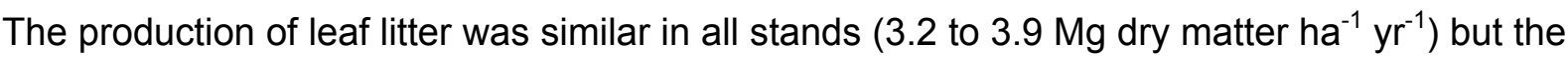
total quantity of $\mathrm{Ca}$ and $\mathrm{Mg}$ deposited on the soil surface by leaf litter increased with increasing tree species diversity and decreasing abundance of beech (47 to $88 \mathrm{~kg} \mathrm{Ca} \mathrm{ha}^{-1}$ $\mathrm{yr}^{-1} ; 3.8$ to $\left.7.9 \mathrm{~kg} \mathrm{Mg} \mathrm{ha}^{-1} \mathrm{yr}^{-1}\right)$. The soil $\mathrm{pH}\left(\mathrm{H}_{2} \mathrm{O}\right)$ and base saturation (BS) measured at three soil depths down to $30 \mathrm{~cm}(0-10 \mathrm{~cm}, 10-20 \mathrm{~cm}, 20-30 \mathrm{~cm})$ were lower in stands dominated by beech ( $\mathrm{pH}=4.2$ to $4.4, \mathrm{BS}=15$ to $20 \%$ ) than in mixed stands $(\mathrm{pH}=5.1$ to 6.5 , $\mathrm{BS}=80$ to $100 \%$ ). The quantities of exchangeable $\mathrm{Al}$ and $\mathrm{Mn}$ increased with decreasing $\mathrm{pH}$ and were highest beneath beech. Total stocks of exchangeable Ca $(0-30 \mathrm{~cm})$ were 12 to 15 times larger in mixed stands (6660 to $\left.9650 \mathrm{~kg} \mathrm{ha}^{-1}\right)$ than in beech stands $\left(620 \mathrm{~kg} \mathrm{ha}^{-1}\right)$. Similar results were found for stocks of exchangeable Mg that were 4 to 13 times larger in mixed stands (270 to $\left.864 \mathrm{~kg} \mathrm{ha}^{-1}\right)$ than in beech stands $\left(66 \mathrm{~kg} \mathrm{ha}^{-1}\right)$. Subsoil clay content and differences in litter composition were identified as important factors that contributed to the observed variability of soil acidification and stocks of exchangeable $\mathrm{Ca}$ and $\mathrm{Mg}$. Organic carbon accumulation in the humus layer was highest in beech stands $\left(0.81 \mathrm{~kg} \mathrm{~m}^{-2}\right)$ and lowest in stands with the highest level of tree species diversity and the lowest abundance of beech $\left(0.27 \mathrm{~kg} \mathrm{~m}^{-2}\right)$. The results suggest that redistribution of nutrients via leaf litter has a high potential to increase base saturation in these loess-derived surface soils that are underlain by limestone. Species-related differences of the intensity of soil-tree cation cycling can thus influence the rate of soil acidification and the stocks and distribution of nutrients. 


\subsection{Introduction}

Natural forest vegetation in Central Europe is unique due to the widespread occurrence of quasi-monospecific beech forests (Fagus sylvatica L.) in which this single species is occupying 80 to $100 \%$ of the canopy area. Land use changes and forest management have greatly reduced the area coverage of these beech forests. Transformation to even-aged monospecific coniferous forests has even resulted in a substantial decrease of forest structural diversity. However, the conversion to mixed stands of beech with other broadleaved or coniferous species increased structural and species diversity.

Changes of tree species can have a pronounced influence on various chemical, physical, and biological soil properties due to differences in nutrient uptake from soil, litter chemistry, root activity, canopy interception and growth (Alriksson and Eriksson, 1998; Binkley and Giardina, 1998). Several studies have shown that the composition of the forest overstory can influence soil nutrient status (Dijkstra, 2003; Berger et al., 2004), mineralization processes on and Lee, 1997), soil acidity (Binkley and Valentine, 1991; Reich et al., 2005) and mineral weathering (Augusto et al., 2000). In addition, tree species can influence the mass of organic carbon stored in the humus layer and in the mineral soil (Raulund-Rasmussen and Vejre, 1995), the composition and activity of soil fauna and microflora (Saetre et al., 1999; Neirynck et al., 2000) and soil structure (Graham et al., 1995). Distinctive differences were found between conifers and hardwood species in affecting soil chemistry or ecosystem biogeochemistry (Rothe et al., 2002; Augusto et al., 2002), but even among hardwood species striking differences can occur (Norden, 1994). Comprehensive reviews on the impact of several common European and American tree species on soil properties were published by Augusto et al. (2002) and Binkley (1995).

Use and management of beech forests in limestone areas of Central Europe often resulted in an admixture of different proportions of other broad-leaved species and an increase of tree species diversity. One outstanding example of a temperate broad-leaved forest with large gradients in beech abundance and tree species diversity is found in the Hainich National Park in Central Germany. Here, different forest ownerships have generated a small-scale stand mosaic of species-poor, beech-dominated forest patches and stands with up to 14 deciduous tree species per hectare that are all growing under similar climate and on the same geological substrate (Triassic limestone (Muschelkalk) covered by loess). In 2005, a long-term study on biogeochemical cycles and biotic interactions in stands with decreasing abundance of beech and associated increasing tree species diversity has been initiated in the Hainich National Park (http://www.forest-diversity.uni-goettingen.de). This study compares i) mature monospecific stands with predominance of European beech (Fagus 
sylvatica L.) to ii) mature stands dominated by three deciduous tree species (beech, ash (Fraxinus excelsior L.), lime (Tilia cordata Mill. and/or T. platyphyllos Scop.) and to iii) mature stands dominated by five deciduous tree species (beech, ash, lime, hornbeam (Carpinus betulus L.), maple (Acer pseudoplatanus L. and/or A. platanoides L.).

Here, we present and discuss results on soil properties in these stands. The objectives of our study were to determine soil acidification, soil nutrient status and the amount and distribution of soil organic matter (SOM) in these stands with different abundance of beech and tree species diversity and to identify and evaluate the main factors that contributed to the variability of these soil properties. Special attention is given to the effects of tree litter composition and to the small scale heterogeneity of soil parent material. We hypothesize that these are pivotal factors in governing the current variability of the surface soil acidity and nutrient status, and of the amount and distribution of SOM.

We like to point out that such an observational study that compares soil properties in existing forest stands with different mixtures of tree species in general has strong limitations with regard to the analysis of putative causal relationships between tree species and soil properties or ecosystem functions because there are no exact replicates of treatments as it is the case in planted experimental stands. In addition, the natural variability of edaphic, climate and soil parent material properties or differences in land use history can introduce several covarying factors (Leuschner et al., 2009). Despite these shortcomings, such observational studies are indispensable to gain an insight into long-term effects of tree species and species diversity on soil properties since planted large-scale biodiversity experiments with trees have been initiated just recently (Scherer-Lorenzen, 2005) and do not yet allow the analysis of long-term effects.

\subsection{Materials and methods}

\subsubsection{Study sites}

The study was conducted in multiple-aged stands of deciduous forest in the Hainich National Park, Thuringia, Central Germany, at an elevation of approximately $350 \mathrm{~m}$ a.s.l. All stands had a high proportion of mature trees with an age of 100 to $200 \mathrm{y}$ and a long-term forest history of at least $200 \mathrm{y}$. Historic forest utilization includes coppice-with-standards systems and selective cutting. Details of stand characteristics are given in Table 1. The mean annual temperature is $7.5^{\circ} \mathrm{C}$ and the mean annual precipitation is $670 \mathrm{~mm}$. The geological substrate of the study sites is Triassic limestone covered by loess. The forest has not been managed since 1990; before that time, it had been used for military training since the 1960s. In December 1997, it became a National Park. In the NE part of the National Park, study plots 
that belong to three different diversity levels ( $D L)$ of tree species were selected: a) monospecies stands with European beech (Fagus sylvatica L.) as predominant tree species (diversity level 1, DL 1), b) three-species stands with beech, ash (Fraxinus excelsior L.) and lime (Tilia cordata Mill. and T. platyphyllos Scop.) as predominant species (diversity level 2, DL 2), and c) five-species stands with beech, ash, lime, hornbeam (Carpinus betulus L.) and maple (Acer pseudoplatanus L., A. platanoides L., A. campestre L.) as predominant species (diversity level 3, DL 3). The mean abundance of beech decreased in the order DL $1>\mathrm{DL} 2$ > DL3 (Table1). Within a radius of approximately $4 \mathrm{~km}$ four replicate plots were selected for each stand type and numbered from a to $d$ (Fig. 1). The main species of the herbaceous layer that were found in all stands were Anemone nemorosa, Hordelymus europaeus, Carex sylvatica, Deschampsia caespitosa, and Milium effusum. Anemone ranunculoides and Asarum europaeum were found in stands of diversity level 2 and 3, and Allium ursinum was typical for stands of the highest diversity level (DL 3) (Mölder et al, 2006).

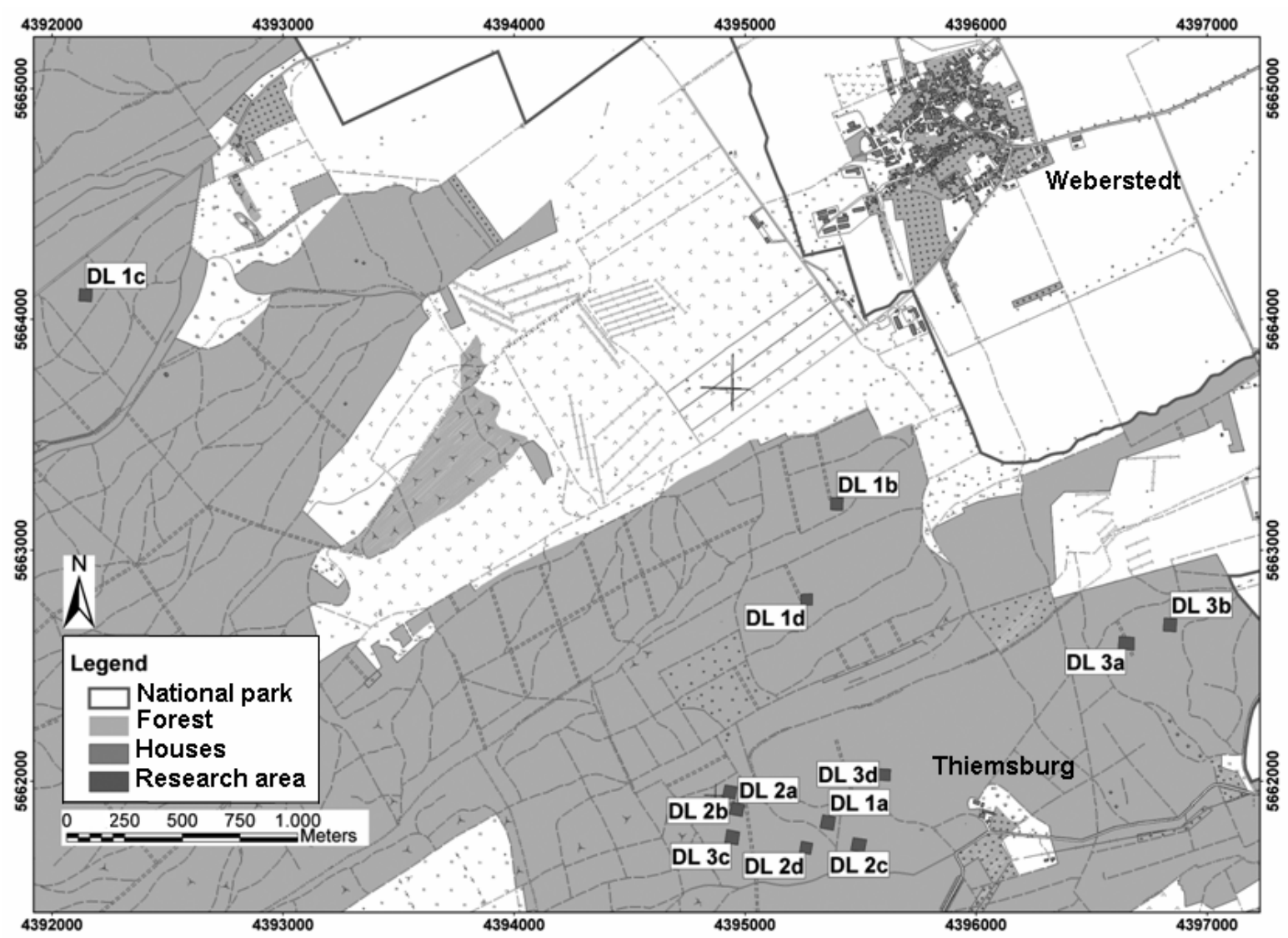

Figure 1: Location of the study plots in the forested (in gray) area of the Hainich National Park (Central Germany). The replicate plots (a to d) are located in stands with different diversity levels of deciduous tree species (DL 1, DL 2, DL 3). 
Chapter 2

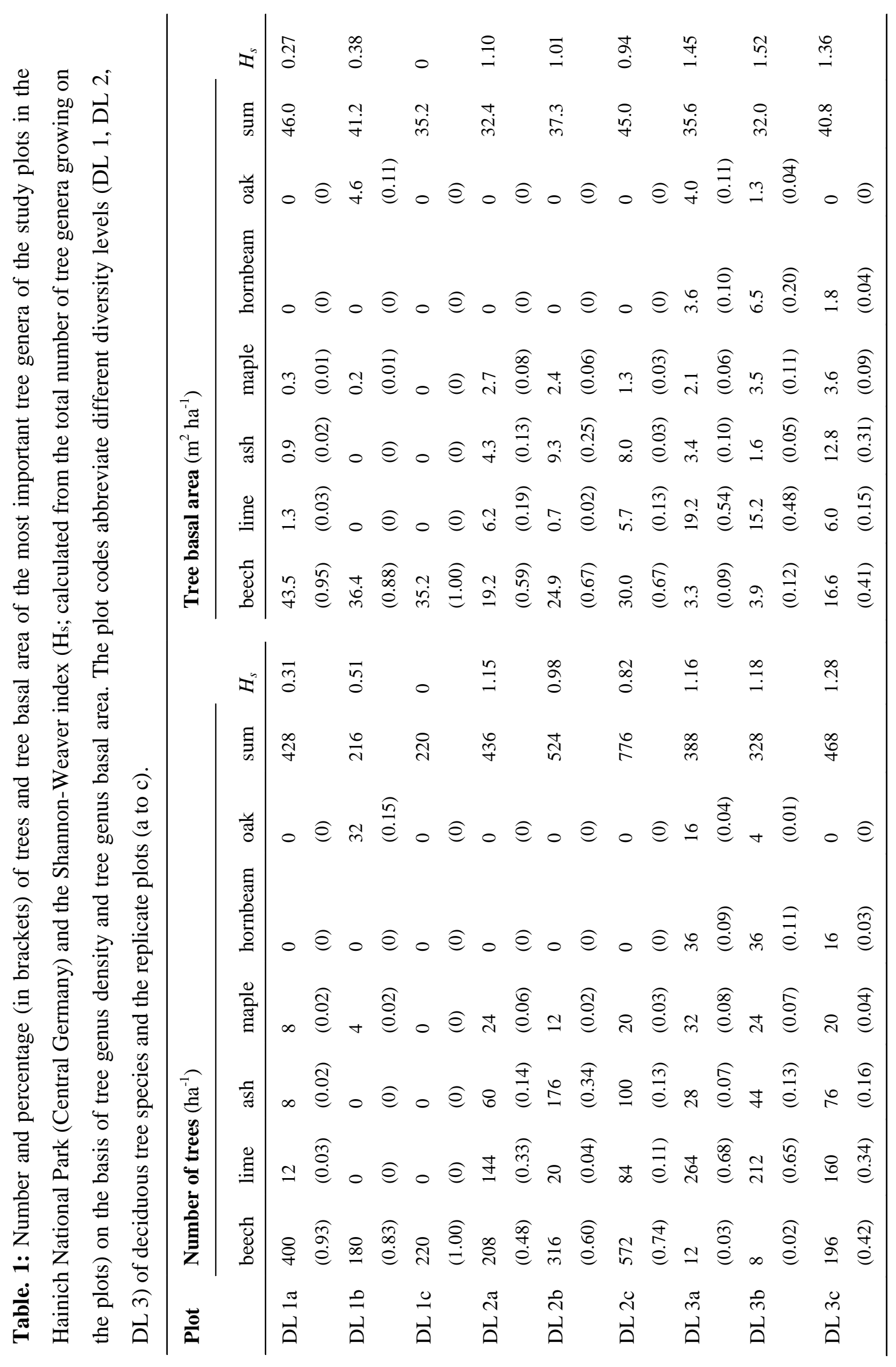


The study sites are close to a meteorological station (Meteomedia, station Weberstedt/Hainich; $51^{\circ} 06^{\prime} \mathrm{N}, 10^{\circ} 31^{\prime} \mathrm{E} ; 270 \mathrm{~m}$ a.s.I.). All plots had to fulfil the following criteria: level or only slightly inclined terrain (inclination $<5 \%$ ) on eutrophic soils formed on limestone with a loess cover of at least $60 \mathrm{~cm}$; near-natural stands without distinct anthropogenic impact on their structure during the last several decades; closed canopy; homogeneous stand structure among all plots. In each stand type, three plots ( $a, b, c)$ met all of the above-mentioned requirements. These were considered core plots, and an area of 54 $\mathrm{m} \times 54 \mathrm{~m}$ around a previously designated central tree was fenced. Within this area, investigations were performed on the innermost $50 \mathrm{~m} \times 50 \mathrm{~m}$ area, which is only walked on for measurement purposes. On each plot, all trees with a diameter at breast height (dbh) of at least $7 \mathrm{~cm}$ were recorded in spring 2005. To evaluate the tree species diversity we computed the Shannon-Weaver index $\left(H_{s}\right)$. This index $\left(H_{s}\right)$ was calculated for both density (number of stems with a $\mathrm{dbh}>7 \mathrm{~cm}$ ) and stem basal area per hectare: $H_{s}=-\Sigma \mathrm{pi}$ In pi, where pi $=$ proportion of total density or of total basal area of tree genus i. $H_{s}$ based on density and $H_{s}$ based on basal area increased in the order DL $1<\mathrm{DL} 2<\mathrm{DL} 3$ (Table 1).

The soil type was a Luvisol developed from loess which is underlain by limestone (FAO, 1998). Soil texture in the upper mineral soil $(0-30 \mathrm{~cm})$ of all plots was characterized by high silt content (mean silt content of $74 \pm 8 \%$ (mean \pm standard deviation)) and low sand content $(<5 \%$ ) (silt loam to silt clay loam, Table 2). The thickness of the loess cover that was generally free of carbonates varied between 60 and $120 \mathrm{~cm}$ (Table 2); it was on average 72 $\mathrm{cm}$ on DL 3 plots, $80 \mathrm{~cm}$ on DL 2 plots and $87 \mathrm{~cm}$ on DL 1 plots. The clay content in 20 to 30 $\mathrm{cm}$ differed depending on the thickness of the clay-depleted $\mathrm{E}$ horizon (Al according to the German classification system) and the depth of the underlying Bt horizon. The mean clay content in 20 to $30 \mathrm{~cm}$ was higher in DL 3 stands (30\%) than in DL 1 stands (15\%) (Table 2) and it was in-between in DL 2 stands (26\%). Tree roots easily reached the calcareous subsoil horizons developed from limestone at each study plot. The two-layer soils (loess over limestone) showed stagnic properties during winter and spring, and they were dry during summer. The soil physical properties of the experimental plots are summarized in Table 2.

\subsubsection{Sampling design}

For soil inventory and sampling within plots a grid of $12 \mathrm{~m} \times 12 \mathrm{~m}$ (12 sampling points per plot) was established within a radius of $25 \mathrm{~m}$ around the central tree. In addition, a soil-profile pit was dug adjacent to each plot. Further, on all plots randomly distributed sampling subplots have been established as follows: Three transects ( $30 \mathrm{~m}$ long and $3 \mathrm{~m}$ wide) were randomly distributed over each plot by randomly determining a) their starting point within a 2 $\mathrm{m} \times 2 \mathrm{~m}$ grid and $b$ ) their angle to the $\mathrm{x}$-axis of this grid. If the transects were not completely located within the $50 \mathrm{~m} \times 50 \mathrm{~m}$ area of the plot or in the case of overlapping, they were 
shifted along the $x$ - and the $y$-axis of the grid to the smallest possible extent. The minimum distance between two transects was $1 \mathrm{~m}$. Along each transect, 31 points (including starting and end point) that were separated by distances of $1 \mathrm{~m}$ were marked. Five of these points were randomly selected for the installation of litter collectors, resulting in a total number of 15 litter collectors per plot.

Table 2: Thickness of the loess cover, soil texture, and soil bulk density of the replicated (a to c) plots with different diversity levels (DL 1, DL 2, DL 3 ) of deciduous tree species.

\begin{tabular}{|c|c|c|c|c|c|c|c|}
\hline \multirow[t]{2}{*}{ Plot } & \multirow{2}{*}{$\begin{array}{l}\text { Thickness } \\
\text { of loess } \\
\text { cover }(\mathrm{cm})\end{array}$} & \multicolumn{3}{|c|}{ Soil texture (sand / silt / clay) (\%) } & \multicolumn{3}{|c|}{ Bulk density $\left(\mathrm{g} \mathrm{cm}^{-3}\right)$} \\
\hline & & $0-10 \mathrm{~cm}$ & $10-20 \mathrm{~cm}$ & $20-30 \mathrm{~cm}$ & $0-10 \mathrm{~cm}$ & $10-20 \mathrm{~cm}$ & $20-30 \mathrm{~cm}$ \\
\hline DL 1a & 120 & $4 / 78$ / 18 & $3 / 82$ / 15 & $4 / 80$ / 16 & 0.9 & 1.1 & 1.4 \\
\hline DL 1b & 70 & $3 / 83$ / 14 & $3 / 83 / 14$ & 4 / 82 / 14 & 1.2 & 1.3 & 1.5 \\
\hline DL 1c & 75 & $3 / 82$ / 15 & $2 / 83 / 15$ & $2 / 83 / 15$ & 1.3 & 1.3 & 1.4 \\
\hline DL 2a & 60 & $2 / 73 / 25$ & $2 / 77 / 21$ & $3 / 73$ / 24 & 1.1 & 1.2 & 1.5 \\
\hline DL 2b & 60 & $3 / 64$ / 33 & 2 / 68 / 30 & 2 / 63 / 35 & 1.0 & 1.3 & 1.4 \\
\hline DL 2c & 120 & $2 / 78 / 20$ & $3 / 80 / 17$ & $3 / 79$ / 18 & 1.2 & 1.4 & 1.6 \\
\hline DL 3a & 75 & $3 / 74 / 23$ & $2 / 74 / 24$ & $2 / 74 / 24$ & 1.0 & 1.2 & 1.3 \\
\hline DL 3b & 80 & 2 / 76 / 22 & $3 / 75 / 22$ & $3 / 75$ / 22 & 1.2 & 1.3 & 1.3 \\
\hline DL 3c & 60 & 2 / 66 / 32 & $3 / 65 / 32$ & $2 / 53 / 45$ & 1.2 & 1.3 & 1.4 \\
\hline
\end{tabular}

\subsubsection{Litter sampling and analyses}

For tree litter sampling, $35 \mathrm{~L}$ buckets with a surface of $0.29 \mathrm{~m}^{2}$ were placed on wooden frames above the forest floor at randomly selected sampling points (see section 2.2). From September to December 2005, the buckets were cleared at monthly intervals. The biomass of leaf litter was determined after drying at $70{ }^{\circ} \mathrm{C}$. Leaf litter from all litter collectors of the same transect line (see 2.2) was mixed resulting in three mixed samples per plot. These mixed samples were ground and used to determine the mean quantity and the mean composition of leaf litter within a plot. Total $\mathrm{C}$ and $\mathrm{N}$ contents were determined by an automated $\mathrm{C}$ and $\mathrm{N}$ analyzer (Heraeus Elementar Vario EL, Hanau, Germany). Concentrations of $\mathrm{Ca}, \mathrm{Mg}, \mathrm{P}$, and $\mathrm{Mn}$ in the litter were determined by ICP-AES (Spectro, Kleve, Germany) after pressure digestion with concentrated nitric acid. The ash alkalinity of leaf litter was determined by titration using the method described by Jungk (1968). 


\subsubsection{Soil sampling and analyses}

In the winter of $2004 / 2005$, soil cores with a diameter of $6.4 \mathrm{~cm}$ were taken from the upper 30 $\mathrm{cm}$ of the soil at all 12 sampling points per plot (see 2.2), and the thickness of the loess cover was determined using a soil auger. Additionally, samples of the organic surface layer were collected at each sampling point (sampled surface of $300 \mathrm{~cm}^{2}$ ). The soil cores were divided into three parts representing the soil depths of 0 to $10 \mathrm{~cm}, 10$ to $20 \mathrm{~cm}$ and 20 to $30 \mathrm{~cm}$. Samples were dried at $40{ }^{\circ} \mathrm{C}$ and passed through a $2 \mathrm{~mm}$ sieve.

Soil $\mathrm{pH}$ was measured in a suspension with distilled $\mathrm{H}_{2} \mathrm{O}$ and $1 \mathrm{M} \mathrm{KCl}(5 \mathrm{~g}$ of soil, $15 \mathrm{ml}$ of $\mathrm{H}_{2} \mathrm{O}$ or $\mathrm{KCl}$ solution). Organic carbon (SOC) and total $\mathrm{N}\left(\mathrm{N}_{\mathrm{t}}\right)$ contents of soil and forest floor samples were determined by an automated $\mathrm{C}$ and $\mathrm{N}$ analyzer (Heraeus Elementar Vario EL, Hanau, Germany) after grinding the samples (all samples were free of carbonates). Cationexchange capacity (CEC) of mineral soil samples was determined at three sampling points per plot. These points were randomly selected from the grid of 12 sampling points (depths of sampling: $0-10,10-20,20-30 \mathrm{~cm}$ ). Soil samples were leached with $100 \mathrm{ml}$ of $1 \mathrm{M}$ ammonium chloride $\left(\mathrm{NH}_{4} \mathrm{Cl}\right)$ for $4 \mathrm{~h}$ as described by König and Fortmann (1996). Cations in the extract were quantified by atomic absorption spectroscopy, and exchangeable protons were calculated from $\mathrm{pH}$ of the $\mathrm{NH}_{4} \mathrm{Cl}$ solution before and after percolation. The CEC was calculated as the equivalent sum of the exchangeable $\mathrm{Na}, \mathrm{K}, \mathrm{Ca}, \mathrm{Mg}, \mathrm{Mn}, \mathrm{Fe}, \mathrm{Al}$ and $\mathrm{H}$ ions. Base saturation was defined as the equivalent sum of base cations ( $\mathrm{Na}, \mathrm{K}, \mathrm{Ca}$ and $\mathrm{Mg}$ ) as percent of CEC. The soil texture was determined using the sieving and pipette method (Schlichting et al., 1995). The texture analysis was performed on all samples that were used for CEC determination. After drying at $105^{\circ} \mathrm{C}$, soil bulk density was determined gravimetrically from undisturbed soil cores $\left(125 \mathrm{~cm}^{3}, \mathrm{n}=3\right)$ taken from the adjacent soilprofile pit.

\subsubsection{Statistical analyses}

To examine differences among the stands ( $D L$ 1, DL 2, DL 3) with regard to (1) the production and composition of tree leaf litter, (2) soil acidification and amount of exchangeable cations, (3) the stocks of soil organic carbon and total nitrogen, (4) the thickness of loess cover, and (5) the clay content we performed an analysis of variance (ANOVA) followed by the Tukey test for all pairwise mean comparisons of diversity level effects. The assumptions of normality and homogeneity of variance were met in nearly all cases ( $p>0.05$; Shapiro-Wilk's test, Levene's test). Only in a few cases (base saturation, stocks of exchangeable $\mathrm{Ca}$ and $\mathrm{Mg}$ ) the $\mathrm{p}$-level of these assumptions were lower $(\mathrm{p}>0.01)$. Differences among species mixtures were analyzed separately for each soil depth. Significant differences were evaluated at the $p<0.05$ level. Correlation (Pearson) and regression analyses were used to analyse the relationship between (1) different soil 
properties, (2) the Shannon index and soil properties, (3) the relative abundance of beech and soil properties, (4) litter $\mathrm{Ca}$ and $\mathrm{Mg}$ contents and soil properties, and (5) the thickness of loess cover and soil properties.

\subsection{Results}

\subsubsection{Production and composition of tree litter}

There was no significant influence of the level of tree species diversity on tree basal area (Table 1) and leaf litter production (Table 3). The $\mathrm{C}: \mathrm{N}$ ratio of litter decreased with increasing tree species diversity from 62 in DL 1 stands to 49 in DL 3 stands (Table 3). Total N input via leaf litter increased with increasing level of tree species diversity (from 26 to $40 \mathrm{~kg} \mathrm{ha}^{-1}$ ). Concentrations of $\mathrm{Ca}$ and $\mathrm{Mg}$ in leaf litter were nearly twice as high 1 in $\mathrm{DL} 3$ stands than in DL 1 stands (Table 3 ) and they were in between in DL 2 stands. Thus, the total quantity of $\mathrm{Ca}$ and $\mathrm{Mg}$ deposited yearly on the soil surface by leaf litter increased in the order DL 1 (47 $\mathrm{kg} \mathrm{Ca}$ and $3.8 \mathrm{~kg} \mathrm{Mg} \mathrm{ha}^{-1}$ ), DL 2 (77 kg Ca and $5.8 \mathrm{~kg} \mathrm{Mg} \mathrm{ha}^{-1}$ ), DL 3 (88 kg Ca and $7.9 \mathrm{~kg}$ $\left.\mathrm{Mg} \mathrm{ha}^{-1}\right)$. There was a close linear relationship between the annual input of $\mathrm{Ca}$ and $\mathrm{Mg}$ via leaf litter and the stocks of exchangeable $\mathrm{Ca}$ and $\mathrm{Mg}$ in the upper $20 \mathrm{~cm}$ of the soils (Fig. 2). The concentration of $P$ in the tree litter was not affected by tree species diversity (Table 3 ). The concentration of $\mathrm{Mn}$ in leaf litter was three to five times higher in beech dominated stands than in mixed stands (Table 3). The ash alkalinity of freshly fallen leaf litter was higher in DL 2 and DL 3 stands than in beech-dominated stands (Table 3).

\subsubsection{Soil organic matter}

Organic-C stocks in the organic surface layer were higher in beech-dominated stands than in mixed stands (Figure 3). Samples of the organic surface layer exhibited a C:N ratio of approximately 30, and $\mathrm{C}: \mathrm{N}$ did not differ among stands with different species diversity level (Table 4). There was mull type humus at all sites, but it exhibited distinct differences. The thin surface layer of mixed stands ( $D L 2, D L 3$ ) consisted primarily of leaf litter from the previous year, whereas in beech-dominated stands (DL 1) litter from several years accumulated and formed a permanent thin layer of partly decomposed tree remains. According to the German classification system, the humus type was L-Mull in DL 2 and DL 3 stands and F-Mull in DL 1 stands (Anonymous, 2005). The mean ratio of C stocks in the organic surface layer to annual $C$ input via tree leaf litter was 5.2 for the beech-dominated sites, 1.8 for stands with diversity level DL 2 and 1.6 for stands with the highest species diversity level ( $D L 3$ ). There was a positive relationship between forest floor $C$ and the relative abundance of beech $\left(R^{2}=0.66\right)$ (Figure 4$)$. 


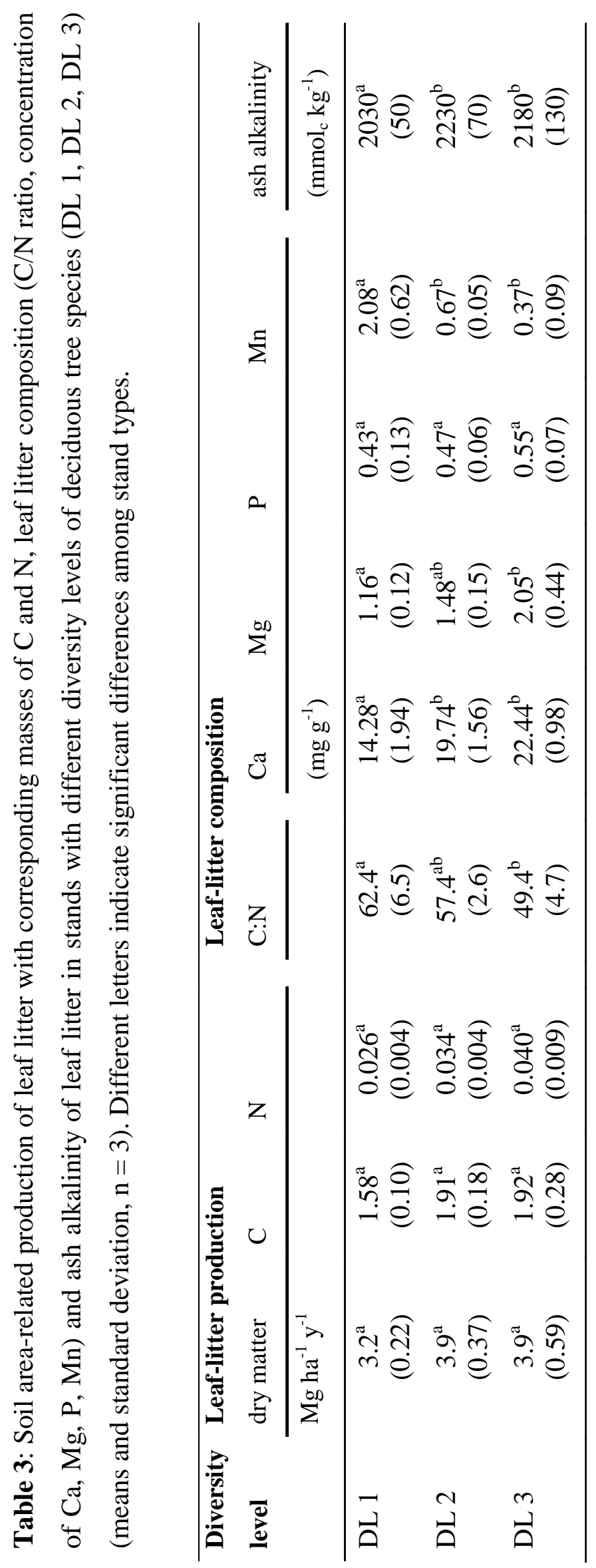


Organic $C$ stocks in the $A$ horizon $\left(0\right.$ to $10 \mathrm{~cm}$ ) ranged from 2.9 to $3.7 \mathrm{~kg} \mathrm{~m}^{-2}$ without significant differences among stand types (Figure 3). Below the A horizon (depths: 10 to 20 and 20 to $30 \mathrm{~cm}$ ), organic matter (OM) contents were higher in mixed stands than in beechdominated stands. However, the close relationship between SOC concentration and clay content $\left(R^{2}=0.87\right.$ and 0.79 in 10 to 20 and 20 to $30 \mathrm{~cm}$, respectively) indicates that these differences were mainly a result of the higher clay content in the subsoil of mixed stands. There was no difference among stand types if the carbon content was related to a unit clay fraction (total soil organic carbon (g clay) ${ }^{-1}$ ).
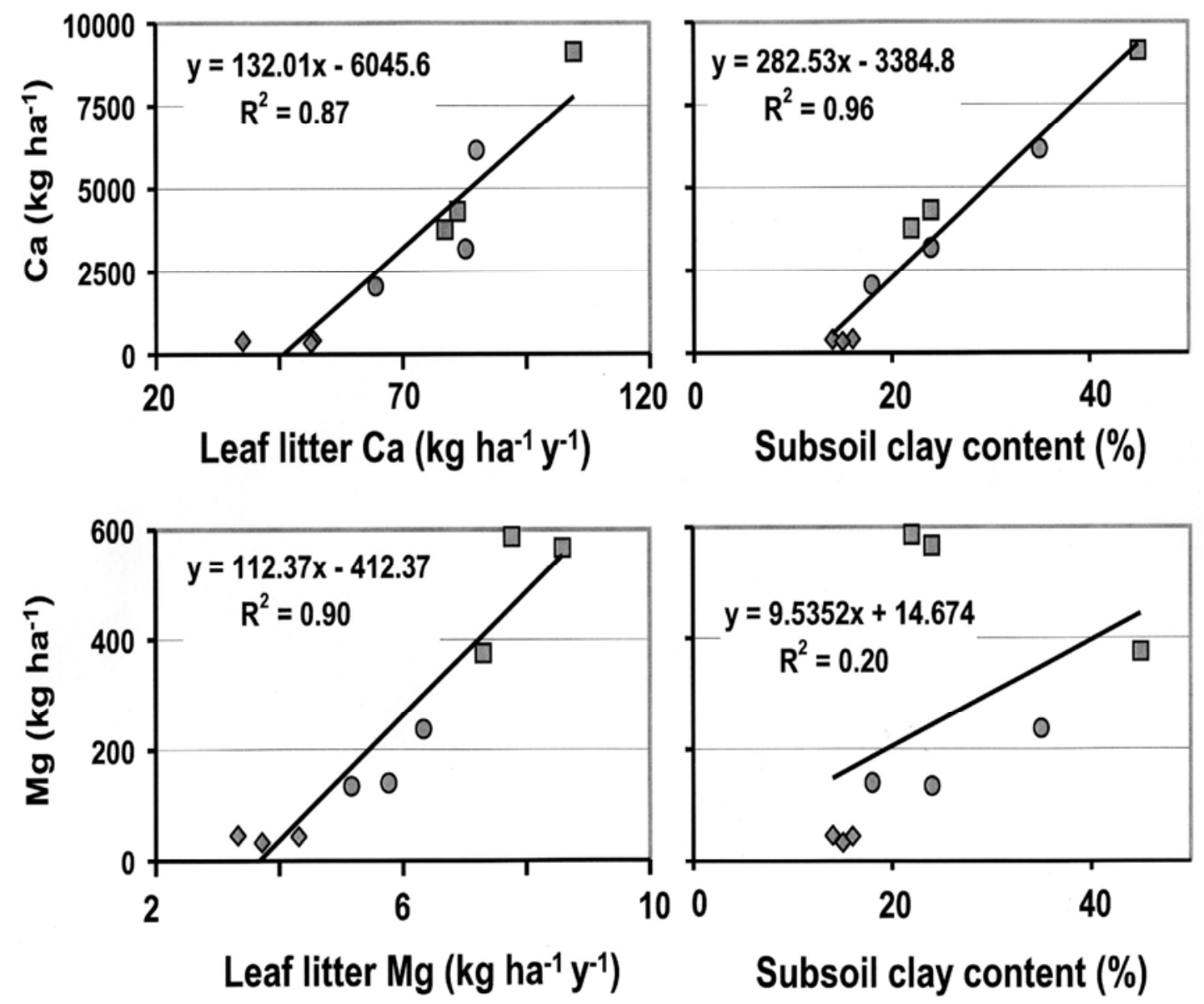

Figure 2: Relationship between the quantity of exchangeable $\mathrm{Ca}$ or $\mathrm{Mg}$ (0 to $20 \mathrm{~cm}$ ) and (1) $\mathrm{Ca}$ and $\mathrm{Mg}$ in leaf litter (left) and (2) the clay content in 20 to $30 \mathrm{~cm}$ (right). The different symbols represent stands with different levels of tree species diversity: $\bullet \mathrm{DL} 1, \bullet \mathrm{DL} 2, \bullet \mathrm{DL} 3$. 


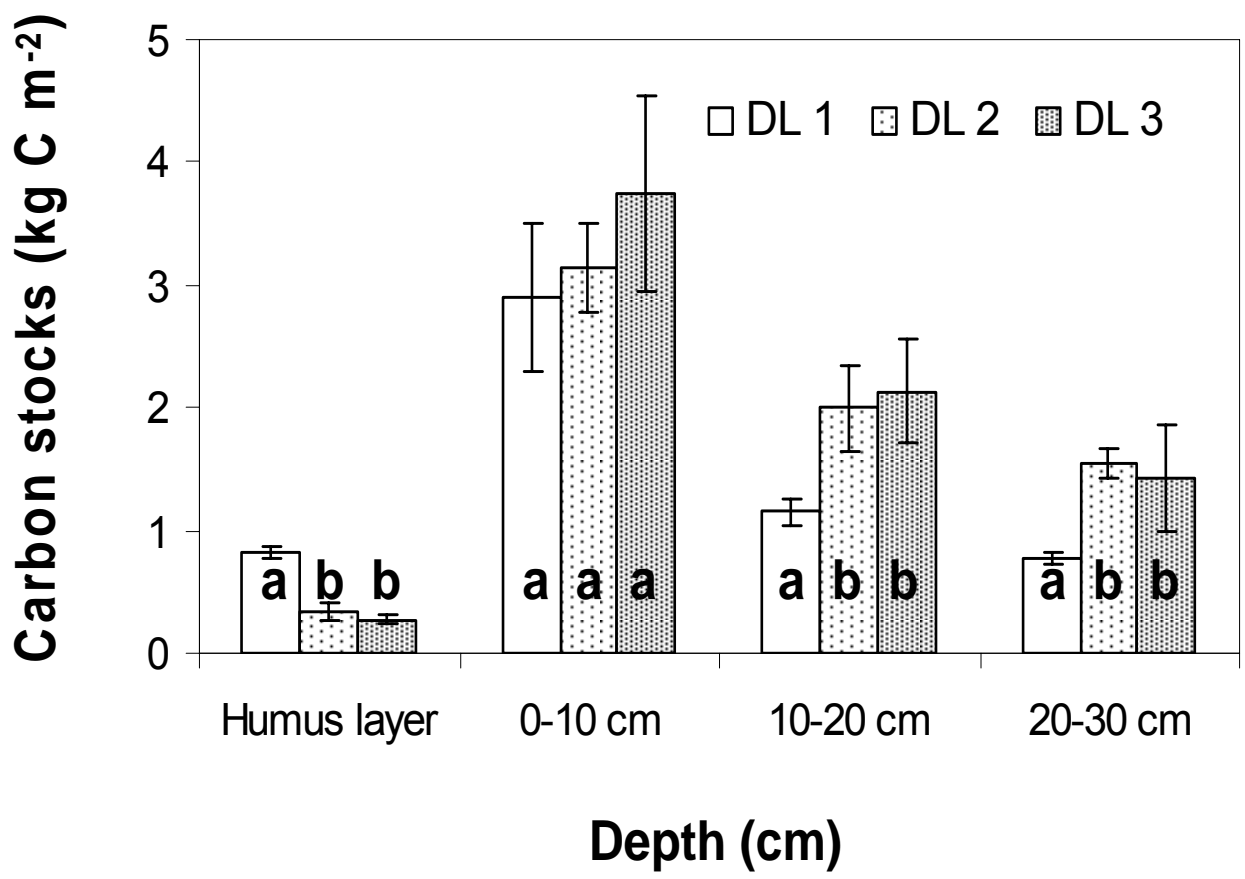

Figure 3: Organic-C stocks in the organic surface layer and at different depths in the mineral soil of stands with different diversity levels of deciduous tree species (DL 1, DL 2, DL 3). (Means and standard deviation, $n=3$ ). Different letters specify significant differences among the diversity levels within a given soil layer.

\subsubsection{Soil acidity and exchangeable cations}

Soil $\mathrm{pH}_{(\mathrm{H} 2 \mathrm{O})}$ was lower in beech stands (DL 1) than in DL 2 or DL 3 stands (Figure 5). It generally increased with soil depth; however, this increase was more pronounced in mixed stands than in beech-dominated stands. There was no significant relationship between the thickness of the loess cover and the $\mathrm{pH}$ of the surface soil $(0-10 \mathrm{~cm})$. However, $\mathrm{pH}$ of the surface soil tended to increase with increasing clay content of the subsoil $(20-30 \mathrm{~cm})\left(\mathrm{R}^{2}=\right.$ $0.41)$.

The CEC of the soil varied considerably within the same stand type (Table 5). It was primarily related to the clay content $\left(R^{2}=0.89\right)$, and its variability could be explained to a large extent by differences in clay content, organic matter concentration and soil pH (Figure $6, \mathrm{R}^{2}=0.93$ ). The specific CEC of soil organic matter (SOM) differed in stands with different tree-species diversity. If we consider the well-established positive relationship between soil $\mathrm{pH}$ and $\mathrm{CEC}$ to SOM in temperate humid climates (Anonymous, 2005), the mean total contribution of SOM to CEC down to a depth of $30 \mathrm{~cm}$ was $2.6 \mathrm{~mol}_{\mathrm{c}} \mathrm{m}^{-2}$ in the beech-dominated soil (DL 1); it was $6.9 \mathrm{~mol}_{\mathrm{C}} \mathrm{m}^{-2}$ in the soil of DL 2 stands; and it was highest under stands with the highest level of tree species diversity (DL 3; $9.9 \mathrm{~mol}_{\mathrm{c}} \mathrm{m}^{-2}$ ) (Figure 7). 

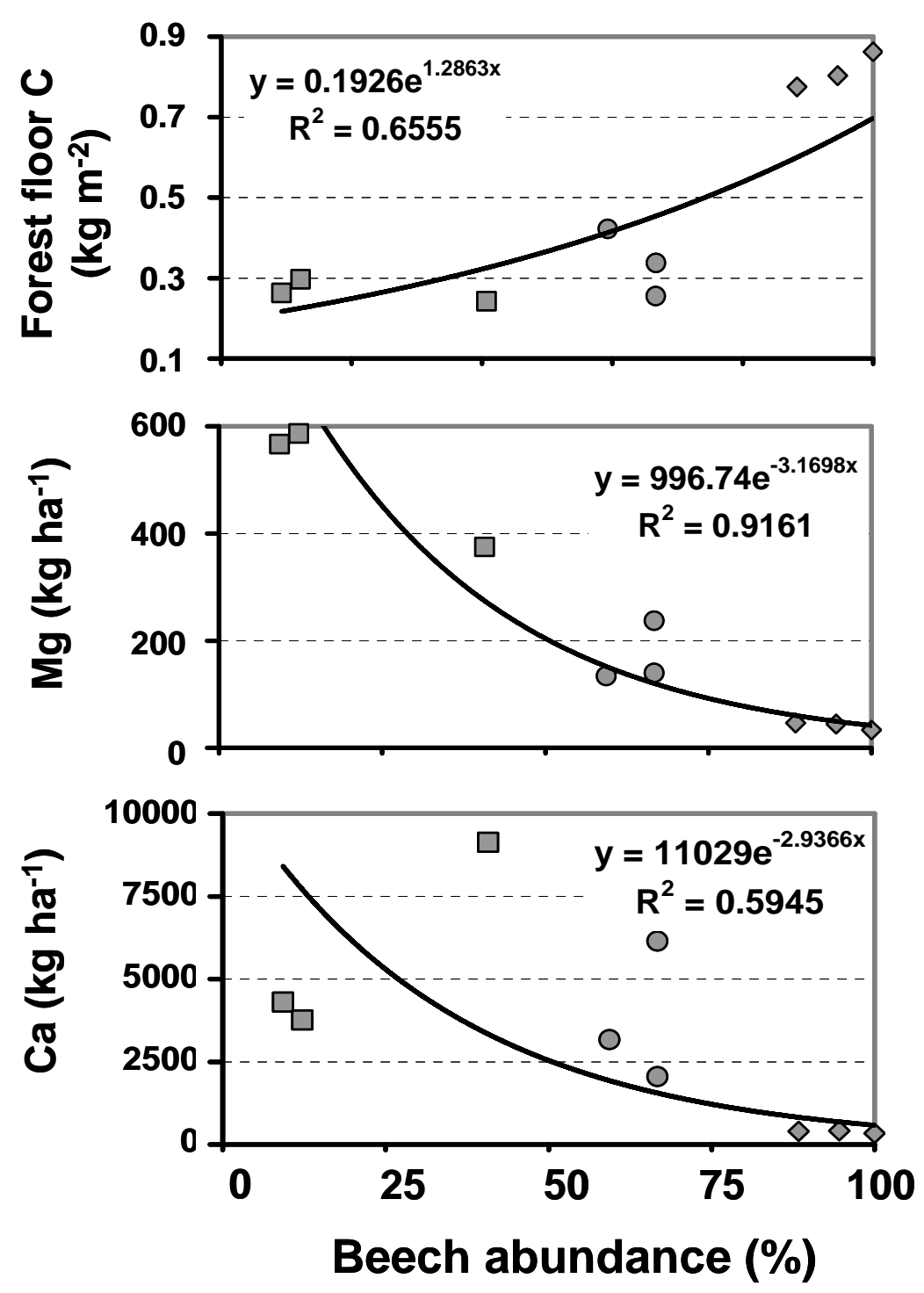

Figure 4: Relationship between the abundance of beech expressed as percentage of the total tree basal area and (1) the $\mathrm{C}$ stocks of the organic surface layer, (2) the quantity of exchangeable $\mathrm{Mg}(0-$ $20 \mathrm{~cm}$ ), and (3) the quantity of exchangeable $\mathrm{Ca}(0-20 \mathrm{~cm})$. The different symbols represent stands with different levels of tree species diversity: $\bullet \mathrm{DL} 1, \bullet \mathrm{DL} 2, \square \mathrm{DL} 3$.

Base saturation in the upper $30 \mathrm{~cm}$ of the mineral soil was much lower in DL 1 stands (< $20 \%$ ) than in mixed stands with several deciduous tree species (DL 2, DL $3>75 \%$ ) (Fig. 5). Exchangeable Al percentage in soil was highest under beech (DL 1) in all soil horizons and lowest in mixed stands with the highest level of species diversity (DL 2, DL 3) (Table 5). Exchangeable Al was generally low in soil samples with $\mathrm{pH}>5$. In contrast, at $\mathrm{pH}<5$ it strongly increased with decreasing $\mathrm{pH}$. Exchangeable $\mathrm{Mn}$ percentage was also higher under beech than in the soil of DL 3 stands, and it also increased with decreasing soil pH. 

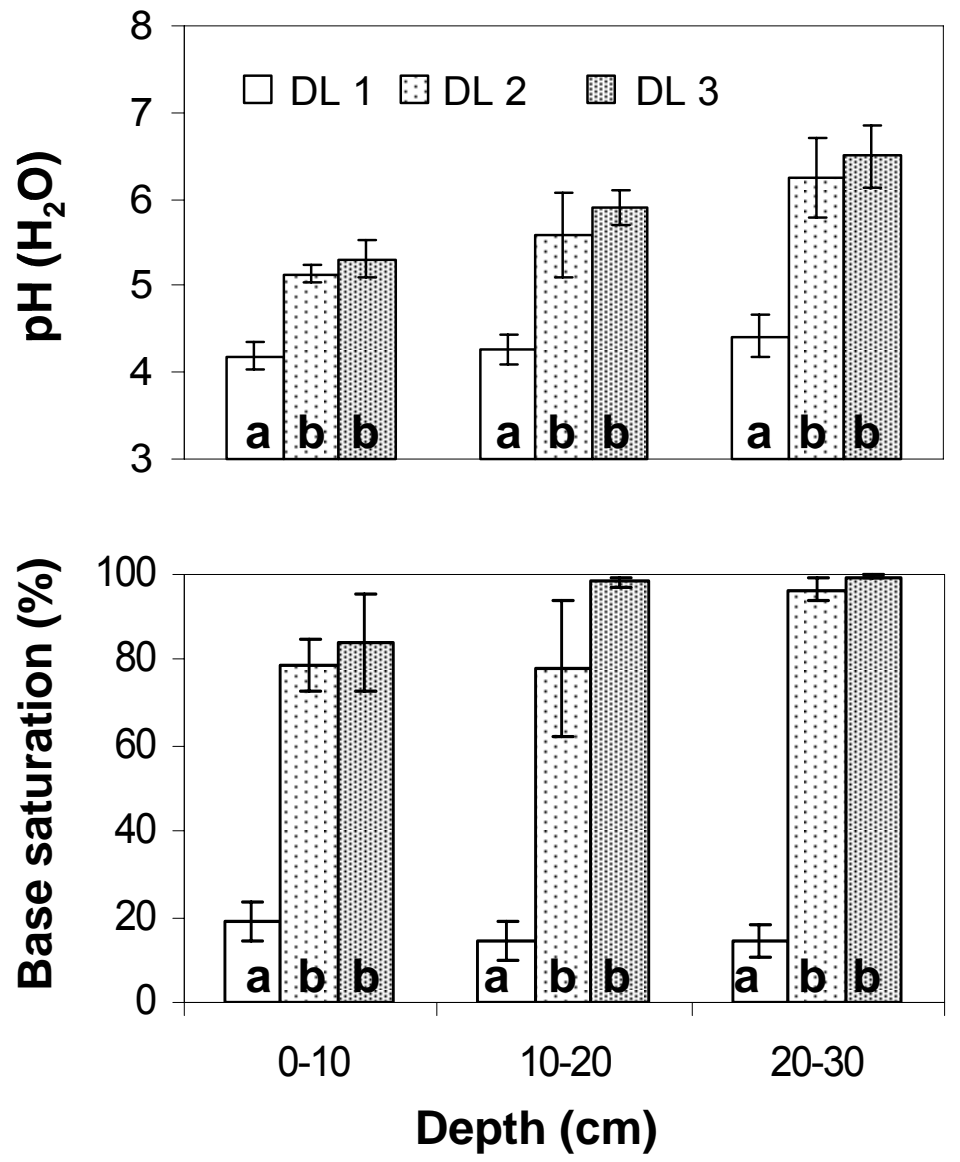

Figure 5: $\mathrm{pH}_{(\mathrm{H} 2 \mathrm{O})}$ and base saturation at different soil depths in stands with different diversity levels of deciduous tree species (DL 1, DL 2, DL 3). (Means and standard deviation, $n=3$ ). Different letters specify significant differences among stands with different diversity level.

Table 4: $\mathrm{C}: \mathrm{N}$ ratio in the organic surface layer and the mineral soil (mean and standard deviation, $\mathrm{n}=3$ ) in stands with different diversity levels of deciduous tree species (DL 1, DL 2, DL 3). Different letters indicate significant differences between stand types within a given soil depth.

\begin{tabular}{lllll} 
Diversity & $\mathbf{C}: \mathbf{N}$ & \multicolumn{3}{l}{$\mathbf{C}: \mathbf{N}($ mineral soil) } \\
\cline { 3 - 5 } level & (organic surface layer) & $0-10 \mathrm{~cm}$ & $10-20 \mathrm{~cm}$ & $20-30 \mathrm{~cm}$ \\
\hline DL 1 & $28.7(1.5)^{\mathrm{a}}$ & $17.2(1.0)^{\mathrm{a}}$ & $13.7(1.0)^{\mathrm{a}}$ & $10.3(0.6)^{\mathrm{a}}$ \\
DL 2 & $31.1(2.7)^{\mathrm{a}}$ & $13.9(0.7)^{\mathrm{b}}$ & $11.8(1.0)^{\mathrm{a}}$ & $9.8(0.3)^{\mathrm{a}}$ \\
DL 3 & $30.9(3.8)^{\mathrm{a}}$ & $14.5(0.7)^{\mathrm{b}}$ & $12.3(0.5)^{\mathrm{a}}$ & $10.5(0.7)^{\mathrm{a}}$
\end{tabular}




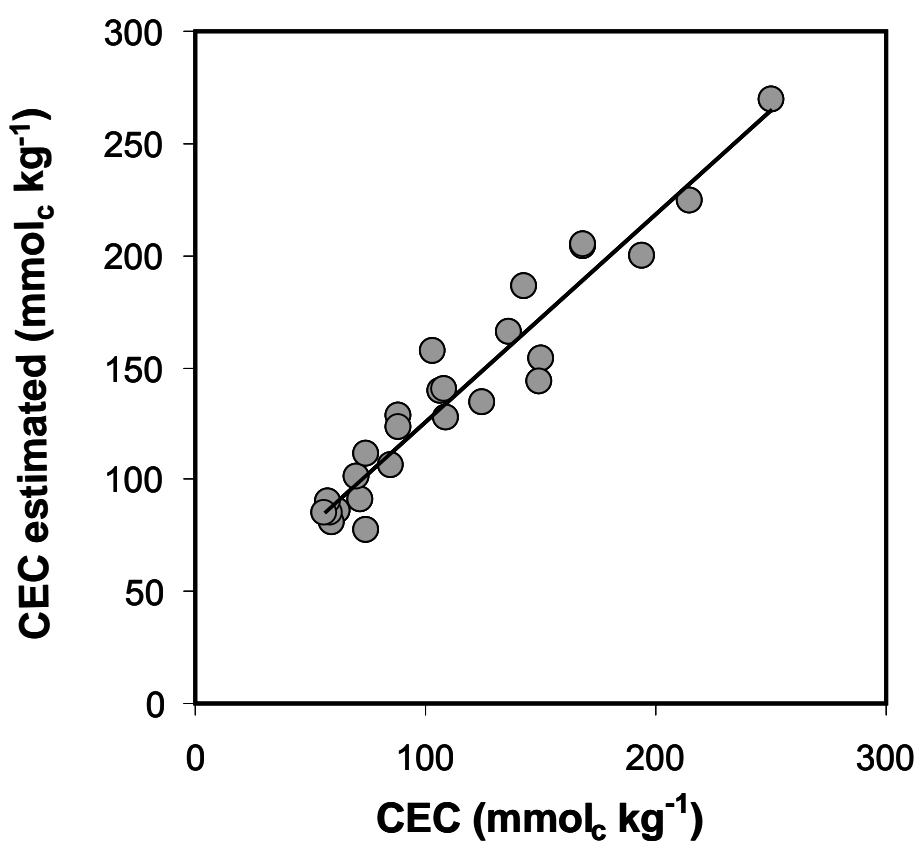

Figure 6: Measured versus estimated cation-exchange capacity (CEC) of soil samples from the experimental plots $\left(R^{2}=0.93\right)$. CEC was estimated from the humus content, clay content and $p H$ using the following equation: CEC $\left(\mathrm{mmol}_{\mathrm{c}} \mathrm{kg}^{-1}\right)=$ [organic matter content $\left(\mathrm{g} \mathrm{kg}^{-1}\right) \times 2 \times f$ ] + [clay content $\left.\left(\mathrm{g} \mathrm{kg}^{-1}\right) \times 0.534\right]$. The reduction factor $f$ depends on soil $\mathrm{pH}$ as shown by "Bodenkundliche Kartieranleitung" (Anonymous, 2005) and describes the decrease of CEC of soil organic matter with decreasing $\mathrm{pH}$.

Total quantities of exchangeable $\mathrm{Ca}$ in the A horizon $(0-10 \mathrm{~cm})$ were approx. 10 times higher in mixed stands (1860-2470 kg ha-1) than under beech (230 kg ha-1) (Table 5). Differences among stands were even more pronounced if exchangeable-Ca stocks were calculated for the upper $30 \mathrm{~cm}$ of soil: it was $620 \mathrm{~kg} \mathrm{Ca} \mathrm{ha}^{-1}$ for DL 1 stands, $6660 \mathrm{~kg} \mathrm{Ca} \mathrm{ha}^{-1}$ for DL 2 stands and $9650 \mathrm{~kg} \mathrm{Ca} \mathrm{ha}^{-1}$ for DL 3 stands. Similar results were found for exchangeable Mg. The stocks of exchangeable Mg were smallest under beech (DL 1) and largest in mixed stands with the highest species diversity level (DL 3). Calculated for the soil layer $0-30 \mathrm{~cm}$, it amounted to $66 \mathrm{~kg} \mathrm{ha}^{-1}$ for DL 1, $270 \mathrm{~kg} \mathrm{ha}^{-1}$ for DL 2 and $864 \mathrm{~kg} \mathrm{ha}^{-1}$ for DL 3 (Table 5). Stocks of exchangeable Mg were particularly high in the soils of the DL $3 a$ and $D L 3 b$ stands where abundance of beech was lowest and where Mg concentration of leaf litter was highest (2.3 $\left.\mathrm{mg} \mathrm{g}^{-1}\right)$. Correlation analysis indicates a close relationship between stocks of exchangeable base cations and the abundance of beech expressed as percentage of the total basal area $\left(R^{2}=0.92\right.$ and 0.59 for $\mathrm{Mg}$ and $\mathrm{Ca}$, respectively) (Figure 4). However, we also found a close relationship between the subsoil $(20-30 \mathrm{~cm})$ clay content and the stock of exchangeable $\mathrm{Ca}$ in the upper $20 \mathrm{~cm}$ of the soil $\left(R^{2}=0.96\right.$, Figure 2$)$. In contrast, there was no close relation between the subsoil $(20-30 \mathrm{~cm})$ clay content and the content of exchangeable $\mathrm{Mg}$ (Figure 2). Stocks of exchangeable $\mathrm{Ca}$ and $\mathrm{Mg}$ in the upper $20 \mathrm{~cm}$ were not related to the thickness of the loess cover. 


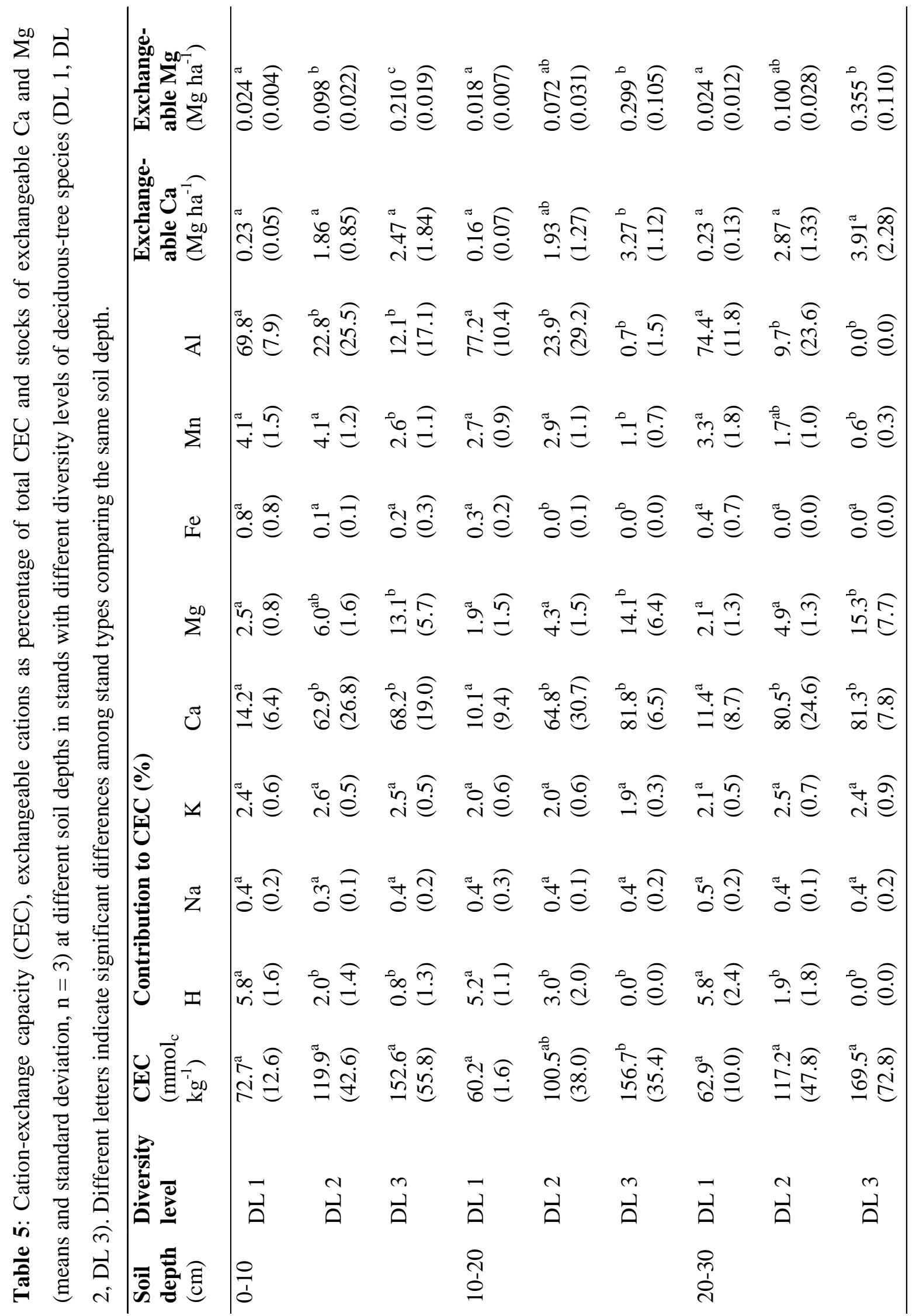




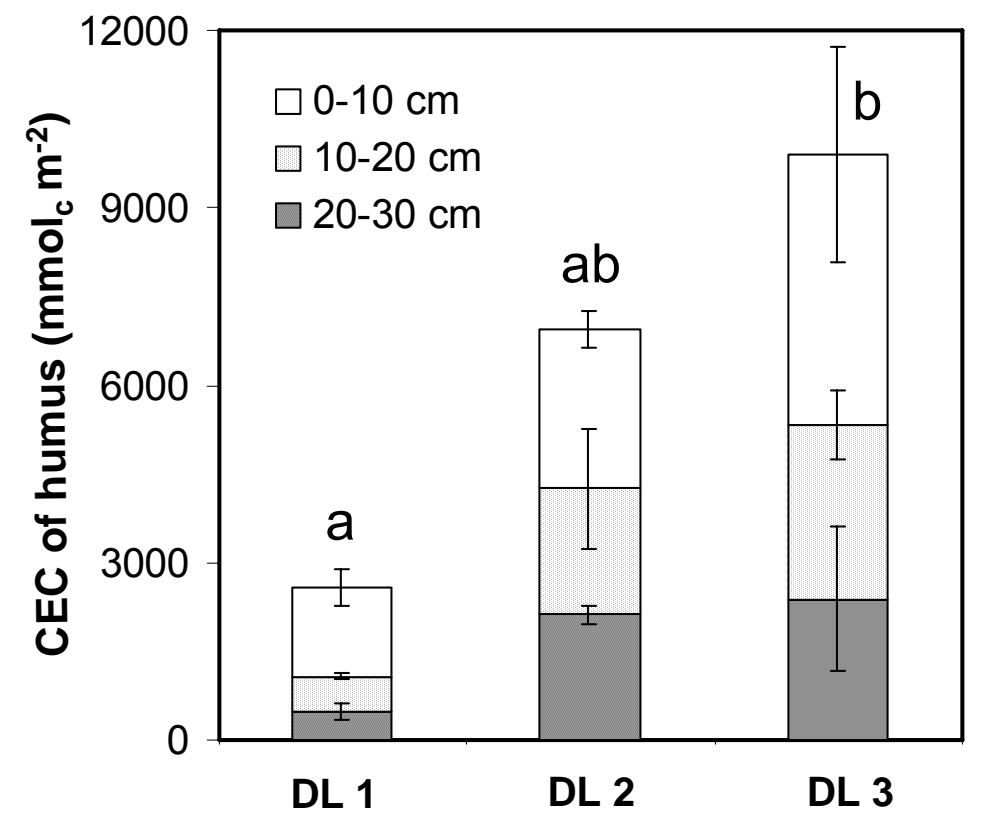

Figure 7: Cation-exchange capacity (CEC) of soil organic-matter stocks down to a depth of $30 \mathrm{~cm}$ in stands with different diversity levels of deciduous tree species (DL 1, DL 2, DL 3) (means and standard deviation, $n=3$ ). Different letters specify significant differences among stands with different diversity level.

\subsection{Discussion}

\subsubsection{Soil acidity and exchangeable cations}

There were large differences in soil $\mathrm{pH}$, BS, and quantity of exchangeable cations among the stands with different diversity levels of deciduous tree species. Differences were significant between beech-dominated stands (DL 1) and mixed stands (DL 2, DL 3), and small or absent if mixed stands with different diversity level were compared. Several factors could have contributed to the result that soil acidification was greater and base saturation was lower in DL 1 stands than in mixed ones (DL 2 and DL 3): (1) differences in the mineral composition of the parent material, in particular variations in the content and composition of the clay fraction among stand types, (2) effects related to the presence of different tree species, in particular effects induced by litter composition and decomposition, the accumulation of inorganic cations in excess of anions in tree biomass and forest floor, and species dependent differences in acid deposition, and (3) differences in the historical land use, in particular if it involved export of biomass and nutrients. 
Due to these manifold factors that might have contributed to the observed differences in soil chemistry and that even interact in their potential effects on soil nutrient status, it is not possible to quantify exactly the effects of single factors in our observational study. However, our results help to assess the potential importance of at least some of these factors.

\subsubsection{Effect of soil parent material}

Soil parent material is a main factor determining nutrient uptake of trees, litter composition and soil acidification (Sariyildiz and Anderson, 2005; Meier et al., 2005). Although we put much effort into the selection of stands with similar parent material and only sites on limestone with a significant loess cover were included (see 2.1), differences in soil parent material, such as thickness of the loess layer, differences in clay content or clay mineralogy might have influenced the degree of soil acidification in the analyzed stands. We found no evidence of a significant influence of the thickness of the loess cover $(60-120 \mathrm{~cm})$ on nutrient stocks or acidity of the surface soil. This is in line with the field observation that tree roots reached the calcareous subsoil in all stands. The results indicate that the loess layer did not act as a significant barrier that hampers nutrient uptake from the calcareous bedrock. The close relationship between clay content and CEC suggests that mineral composition of the clay fraction was similar in all soil samples even if the clay content differed considerably. Thus, differences in soil chemistry cannot be explained by a different mineralogy of the clay fraction. The observed CEC of the clay fraction $\left(0.534 \mathrm{mmol}_{\mathrm{c}} \mathrm{g}^{-1}\right.$, regression equation in the title of Figure 6) is typical for loess-derived soils in Central and Northern Germany (Renger, 1965).

Our results suggest that the subsoil $(20-30 \mathrm{~cm})$ clay content was a decisive factor that determined the variability of the exchangeable $\mathrm{Ca}$ content in the surface soil. The highly significant relationship between these soil properties indicates that an increasing subsoil clay content reduced soil acidification and losses of exchangeable base cations probably by providing increasing subsoil nutrient stocks and acid neutralization capacity. However, differences in clay content were relatively small if compared with the observed large variability of exchangeable-Ca and -Mg stocks in the upper $20 \mathrm{~cm}$ that were 12 and 15 times higher in DL 3 stands than DL 1 stands. In addition, differences in subsoil clay content only partly explained the variability of exchangeable $\mathrm{Mg}$ in the surface soil. The results suggest that the subsoil clay content was an important but not the only factor that contributed to the observed differences of soil acidification and stocks of exchangeable nutrients. 


\subsubsection{Effects related to tree species}

The evaluation of tree species effects is hampered by the fact that clay content was higher in mixed stands (DL 2, DL 3) than in beech stands (DL 1) and that both factors (i.e. soil texture and tree species) have probably contributed to the observed differences in soil chemistry. Nevertheless, the results on nutrient recycling via leaf litter provide insight into the potential of the investigated species mixtures to influence soil acidity and stocks of exchangeable cations.

The quantity of litterfall was similar in all stands, but annual deposition of $\mathrm{Ca}, \mathrm{Mg}$ and alkalinity to the soil surface via leaf litter increased with increasing species diversity and decreasing abundance of beech. Calculated for a period of $50 \mathrm{y}$ total $\mathrm{Ca}$ and $\mathrm{Mg}$ deposition via leaf litter of trees was by $2057 \mathrm{~kg} \mathrm{Ca} \mathrm{ha}^{-1}$ and $205 \mathrm{~kg} \mathrm{Mg} \mathrm{ha}^{-1}$ higher in DL 3 stands than DL1 stands. This is in the same order of magnitude as the observed differences of exchangeable $\mathrm{Ca}$ and $\mathrm{Mg}$ in the Ah horizon of these stands and shows the great potential of tree litter composition to influence stocks of exchangeable cations in the upper soil horizon. The close relationships between litter $\mathrm{Ca}$ and $\mathrm{Mg}$ and stocks of exchangeable $\mathrm{Ca}$ and $\mathrm{Mg}$ in the surface soil $(0-20 \mathrm{~cm})$ supports this conclusion even if the results raise the question about the cause-effect chain. Are stocks of exchangeable $\mathrm{Ca}$ and $\mathrm{Mg}$ large because of high $\mathrm{Ca}$ and $\mathrm{Mg}$ inputs via leaf litter or are litter concentrations high because of the high nutrient availability? Both factors are closely linked and cannot be separated. However, long-term changes of the surface soil nutrient status are strongly influenced by the ability of different tree species to improve or maintain soil productivity via nutrient uptake and redistribution (Neirynck et al., 2000). Differences in subsoil clay content have probably contributed to the higher litter $\mathrm{Ca}$ and $\mathrm{Mg}$ concentrations in mixed stands than beech stands. However, the effect of clay content on litter composition was probably minor because we found no relationship between subsoil clay content and litter $\mathrm{Ca}$ and $\mathrm{Mg}$ within mixed stands. Moreover, the mixed stands with relatively low subsoil clay content (DL 2c, DL 3b) also showed much higher leaf litter $\mathrm{Ca}$ and $\mathrm{Mg}$ contents than beech stands. The results suggest that the differences in litter $\mathrm{Ca}$ and $\mathrm{Mg}$ were largely driven by species-specific differences in litter quality. This conclusion is also supported by first results on leaf litter composition of different tree species in the mixed stands DL 2 and DL 3 that indicate lowest $\mathrm{Ca}$ and $\mathrm{Mg}$ concentrations in beech and oak litter (Jacob, personal communication).

Our results support the observation that litter quality of different species and the associated nutrient recycling through the soil-tree system can have significant implications for the pattern of soil fertility and soil acidity in mixed stands (Norden, 1994; Finzi et al., 1998a; Rothe and Binkley, 2001). The striking differences between beech-dominated stands (DL 1) 
and mixed stands (DL 2, DL 3) suggest that the presence and abundance of beech contributed to the observed differences in soil acidity and availability of $\mathrm{Ca}$ and $\mathrm{Mg}$. This assumption is supported by the significant negative correlation between the percentage of beech expressed as proportion of tree basal area and the stocks of exchangeable $\mathrm{Ca}$ and $\mathrm{Mg}$ and the positive relationship between the abundance of beech and the accumulated soil acidity in the form of exchangeable Al. Several studies have reported distinct differences among deciduous tree species in their ability to acidify the upper mineral soil in terms of a decrease of exchangeable base cation pools and increase of exchangeable Al. In deciduous forests in Sweden, Tilia cordata acidified the soil the least, whereas sites covered by Fagus sylvatica exhibited considerably lower pH values and base saturation (Norden, 1994). Similar results were reported by Finzi et al. (1998a) and Neirynck et al. (2000), who found much lower $\mathrm{pH}$ and base saturation beneath canopies of Fagus species than under Tilia, Fraxinus and Acer species. In these studies, the largest differences in soil acidification occurred beneath Acer sacccharum and Fagus grandifolia, and Tilia platyphyllos and Fagus sylvatica, respectively. Augusto et al. (2002) summarized effects of tree species on soil fertility in European temperate forests and concluded that the acidifying ability of Fagus sylvatica and Quercus species was higher than that of all other deciduous tree species. The ability of tree species to change chemical soil properties related to acidity and exchangeable cations was shown to be largely mediated by litter $\mathrm{Ca}$ and $\mathrm{Mg}$ concentrations and litter ash alkalinity (Noble and Randall, 1999; Dijkstra, 2003; Reich et al., 2005), which fits to our results on litter quality and soil acidity in stands of different diversity levels. Differences among tree species growing under similar soil and climate conditions in nutrient uptake and leaf litter chemistry are considered as intrinsic species-specific traits, and several mechanisms of enhanced nutrient acquisition that are primarily related to growth and activity of roots or mycorrhiza have been described (Washburn and Arthur, 2003; Reich et al., 2005). The redistribution of $\mathrm{Ca}, \mathrm{Mg}$ and alkalinity in the soil profile by different tree species through nutrient uptake, litter deposition and mineralization and the induced changes in soil chemistry depend on the nutrient availability and buffer capacity in different soil depths (Noble and Randall, 1999; Augusto et al., 2002; Meier et al., 2005). At our experimental plots, this process of "biological pumping" had a highly beneficial effect since it enabled the translocation of base cations and alkalinity from the alkaline subsoil (limestone) to the surface parent material (loess), which has a rather low buffer capacity and thus tends to form strongly acid forest soils. This ameliorating effect obviously differed due to the abundance of different tree species. It counteracted the accumulation of acidic cations such as $\mathrm{Al}^{3+}, \mathrm{Mn}^{2+}$ and $\mathrm{Fe}^{3+}$ at the exchange complex and, thus, reduced the replacement of exchangeable "base" cations, in particular $\mathrm{Ca}^{2+}$. 
Even if it was not possible in our study to clearly separate effects of clay content and tree species mixtures, the results show that differences in litter composition in the analyzed stands have a high potential to change the soil nutrient status. Thus, we consider tree litter composition as an important factor that contributed to the observed differences of base saturation and acidification of the surface soil.

Decomposition of litter can contribute to soil acidification by the production of organic acids or by providing substrate for nitrification (if nitrate is leached) (Finzi et al., 1998a). There is no evidence that these processes were important at our sites since high organic acid production occurs if litter decomposition is slow and a thick forest floor developed (this was not the case at our sites), and first results on $\mathrm{N}$ mineralization indicated that nitrification was very low in all stands (data not shown).

Soil acidity and stocks of exchangeable "base" cations in different stands can also be influenced by the accumulation of inorganic cations in excess of anions in tree biomass (Bredemeier et al., 1990; Norden, 1994). The internal net proton production by this process in different German forests was between 0.3 and $1 \mathrm{kmol}_{\mathrm{C}} \mathrm{ha}^{-1} \mathrm{y}^{-1}$ (Bredemeier et al., 1990). The higher values were associated with high contents of "base" cations in tree biomass. Norden (1994) reported similar results for deciduous forests in South Sweden and showed that differences between deciduous tree species (Fagus, Quercus, Tilia, Acer) growing at the same site were small. If these results are considered, it is unlikely that this process can explain the large difference of stored acidity in the analyzed soils. Even if we consider soil acidity solely in the form of exchangeable $\mathrm{Al}$ in the upper $20 \mathrm{~cm}$, it was much higher in beech-dominated stands ( $D L 1 ; 109 \mathrm{kmol}_{\mathrm{c}} \mathrm{ha}^{-1}$ ) than in stands with higher tree species diversity (DL2: $61 \mathrm{kmol}_{\mathrm{c}} 28 \mathrm{ha}^{-1}$; DL 3: $22 \mathrm{kmol}_{\mathrm{c}} \mathrm{ha}^{-1}$ ).

Deposition effects may also be important since the capacity of tree species to intercept atmospheric deposition is known to influence soil acidity and nutrient leaching (Augusto et al., 2002). Crown surface properties of the trees determine deposition rates, and it is well documented that interception is higher in stands of coniferous species than in stands of deciduous species because of the higher leaf area index and, in most cases, persistent foliage (Augusto et al., 2002). There are only a few studies that have determined the influence of different deciduous tree species on atmospheric deposition (review by Augusto et al., 2002). Norden (1991) analyzed acid deposition and throughfall fluxes for five deciduous tree species (Fagus sylvatica, Quercus robur, Carpinus betulus, Tilia cordata, Acer platanoides) in S Sweden and found only small differences of the total acid input: the mean $( \pm \mathrm{sd})$ acid input calculated over all species was $2.0( \pm 0.2) \mathrm{kmol}_{\mathrm{c}} \mathrm{ha}^{-1} \mathrm{y}^{-1}$. Thus, there 
is no evidence of large species-related differences of atmospheric deposition that could explain the different acidification in the analyzed soils.

\subsubsection{Land-use history}

The forest history, in particular if it involved biomass and nutrient export as charcoal production, litter raking or grazing can significantly increase soil acidification and decrease base saturation (Hüttl and Schaaf, 1995). The present composition and diversity of tree species in the Hainich National Park is strongly determined by former forest use and management. It indicates that former management of the investigated stands differed. Although historical documents provide no evidence of different biomass export from our experimental sites or former agricultural use, we cannot exclude the possibility that present soil conditions might be influenced by historical land use since such effects can persist for very long periods. We consider historical land use as the main factor of uncertainty that might have contributed to the observed differences in base saturation and acidification of the surface soil.

\subsubsection{Soil organic matter}

There was a striking effect of tree species on $\mathrm{C}$ and $\mathrm{N}$ stocks in the forest floor. The larger $\mathrm{C}$ and $\mathrm{N}$ accumulation in the organic surface layer of beech-dominated stands (DL 1) compared to DL 2 and DL 3 stands was not due to higher litter production, but to lower decay rates in the DL 1 stands. This can be explained by the relatively high recalcitrance of beech litter that was found to depend on the lower nutrient concentrations and on the higher lignin to $\mathrm{N}$ ratio compared with litter of Acer and Fraxinus species (Melillo et al., 1982; Finzi et al., 1998b). In addition, litter decomposition probably was hampered by the lower soil pH. Our findings are in accordance with the results of other studies that showed that the organic surface layer generally is thicker beneath beech than beneath other hardwood species with the exception of oak (Finzi et al., 1998b; Neirynck et al., 2000). Neirynck et al. (2000) concluded that Fagus and Quercus belong to mullmoder-forming species, whereas Tilia, Acer and Fraxinus are mull-forming trees. The results suggest that the abundance of beech was the key factor that determined the mass of the organic surface layer at our experimental sites. This conclusion is supported by the significant positive correlation between the percentage of beech expressed as the proportion of tree basal area and the quantity of $C$ stocks in the organic surface layer. Similar forest floor $C$ stocks under beech were reported for other limestone areas in Central Europe (Leuschner et al., 2006). Differences in the $C$ to $\mathrm{N}$ ratio were found for leaf litter of different stands but not for forest floor samples. This might be explained by the accumulation of more decomposed tree remains under beech that have very likely a narrower $\mathrm{C} / \mathrm{N}$ ratio compared with the fresh litter material in mixed stands. 
Differences in the organic carbon content of the mineral soil (comparing the same soil depth) resulted mainly from differences in the clay content and there was no evidence of a significant effect of the tree species diversity.

The results show that the quality of soil organic matter in terms of its ability to bind and store exchangeable cations was lower in beech-dominated stands than in stands with higher portions of lime, ash and maple. This was due to the strong effect of $\mathrm{pH}$ on the surface charge soil organic matter and, thus, on the factors that contributed to the variability of soil acidification (see 4.1).

\subsection{Conclusion}

We found distinct differences in surface soil acidification, stocks of exchangeable base cations and carbon accumulation in the humus layer in temperate broad-leaved mixed forest stands on loess over limestone. Subsoil clay content and differences in litter composition were identified as important factors that contributed to the variability of these soil properties. The redistribution of $\mathrm{Mg}, \mathrm{Ca}$ and alkalinity via tree litter has a high potential to increase base saturation in these loess-derived surface soils that are underlain by limestone. Our results suggest that this process of "biological pumping" of base cations increased with decreasing abundance of beech. In addition, beech abundance influenced litter decomposition rate and nutrient accumulation in the organic surface layer. Thus, the conversion of quasi monospecific beech forests to mixed stands of beech with other broad-leaved species appeared to increase the intensity of soil-tree cation cycling and as a consequence it can influence the rate of soil acidification and nutrient stocks in the surface soil. The results suggest that at sites that allow production of broadleaf tree species with nutrient-rich, easily decomposable foliage the establishment and promotion of these species is an important silvicultural tool to counteract natural or anthropogenic soil acidification and to maintain soil productivity.

However, the significance of our results is impaired by the interfering effects of soil texture and tree species composition, and in addition, by the uncertainty associated with the historical land use. A follow-up study will be conducted in clusters of single tree species within the selected stands to reduce these factors of uncertainty and to constrain the effects of tree species composition on soil properties. 


\section{Acknowledgements}

The study was funded by the Deutsche Forschungsgemeinschaft (DFG; Graduiertenkolleg 1086). We thank Inga Mölder for helpful discussion on historical land use.

\subsection{References}

Alriksson, A., Eriksson, H. M., 1998. Variations in mineral nutrient and C distribution in the soil and vegetation compartments of five temperate tree species in NE Sweden. For. Ecol. Manage. 108, 261-273.

Anonymous, 2005. Bodenkundliche Kartieranleitung. Bodenkundliche Kartieranleitung. Bundesanstalt für Geowissenschaften und Rohstoffe und Geologische Landesämter der Bundesrepublik Deutschland (Eds), Schweizerbart'sche Verlagsbuchhandlung, Stuttgart, Germany.

Augusto, L., Turpault, M.P., Ranger, J., 2000. Impact of tree species on feldspar weathering rates. Geoderma 96, 215-237.

Augusto, L., Ranger, J., Binkley, D., Rothe, A., 2002. Impact of several common tree species of European temperate forests on soil fertility. Ann. For. Sci. 59, 233-253.

Berger, T.W., Köllensperger, G., Wimmer, R. 2004. Plant-soil feedback in spruce (Picea abies) and mixed spruce-beech (Fagus sylvatica) stands as indicated by dendrochemistry. Plant Soil 264, 69-83

Binkley, D., 1995. The influence of tree species on forest soils: Processes and patterns. In: Mead, D.J., Cornforth, I.S. (Eds.), Proceedings of the Trees and Soils Workshop, Lincoln University 28 February-2 March 1994. Agronomy Society of New Zealand, Special Publications No. 10, Lincoln University Press, Canterbury, New Zealand.

Binkley D., Giardina, C., 1998. Why do tree species affect soils? The warp and woof of tree soil interactions. Biogeochemistry 42, 89-106.

Binkley D., Valentine, D., 1991. Fifty-year biogeochemical effects of green ash, white pine and Norway spruce in a replicated experiment. For. Ecol. Manage. 40, 13-25.

Bredemeier, M., Matzner, E., Ulrich, B., 1990. Internal and external proton load to forest soils in Northern Germany. J. Environ. Qual. 19, 469-477. 
Dijkstra, F.A., 2003. Calcium mineralization in the forest floor and surface soil beneath different tree species in the northeastern US. For. Ecol. Manage. 175, 185-194.

FAO, 1998. FAO, ISRIC, ISSS World Reference Base for Soil Resources. World Soil Resources Reports 84. Rome, Italy.

Finzi, A.C., Canham, C.D., Van Breemen, N., 1998a. Canopy tree-soil interactions within temperate forests: Species effects on $\mathrm{pH}$ and cations. Ecol. Appl. 8, 447-454.

Finzi, A.C., Canham, C.D., Van Breemen, N., 1998b. Canopy tree-soil interactions within temperate forests: Species effects on soil carbon and nitrogen. Ecol. Appl. 8, 440-446.

Graham, R.C., Ervin, J.O., Wood, H.B., 1995. Aggregate stability under oak and pine after four decades of soil development. Soil. Sci. Soc. Am. J. 59, 1740-1744.

Hüttl, R.E., Schaaf, W., 1995. Nutrient supply of forest soils in relation to management and site history. Plant Soil 168-169, 31-41.

Jungk, A., 1968. Die Alkalität der Pflanzenasche als Maß für den Kationenüberschuß in der Pflanze. Z. Pflanzenernähr. Bodenk. 120, 99-105.

König, N., Fortmann, H., 1996. Probenvorbereitungs-, Untersuchungs- und Elementbestimmungsmethoden des Umweltanalytiklabors der Niedersächsischen Forstlichen Versuchsanstalt und des Zentrallabor 2 des Forschungszentrums Waldökosysteme. Berichte des Forschungszentrums Waldökosysteme, Reihe B, Band 49, Göttingen, Germany.

Leuschner, C., Jungkunst, H.F., Fleck, S., 2009 Functional role of forest diversity: pros and cons of synthetic stands and across-site comparisons in established forests. Basic and Applied Ecology, 10, 1-9

Leuschner, C., Meier, I.C., Hertel, D., 2006. On the niche breadth of Fagus sylvatica: soil nutrient status in 50 Central European beech stands on a broad range of bedrock types. Plant Ann. For. Sci. 63, 355-368.

Meier, I.C., Leuschner, C., Hertel, D., 2005. Nutrient return with litter fall in Fagus sylvatica forests across a soil fertility gradient. Plant Ecology $177,99-112$.

Melillo, J.M., Aber, J.D., Muratore, J.F., 1982. Nitrogen and lignin control of hardwood leaf litter decomposition dynamics. Ecology 63, 621-626. 
Mölder, A., Bernhardt-Römermann M., Schmidt, W. 2006. Forest ecosystem research in the Hainich National Park (Thuringia): First results on flora and vegetation in stands with contrasting tree species diversity. Waldökologie-Online 3, 83-99

Neirynck, J., Mirtcheva, S., Sioen, G., Lust, N., 2000. Impact of Tilia platyphyllos Scop., Fraxinus excelsior L., Acer pseudoplatanus L., Quercus robur L. and Fagus sylvatica L. on earthworm biomass and physico-chemical properties of a loamy soil. For. Ecol. Manage. 133, 8 275-286.

Noble, A.D., Randall, P.J., 1999. Alkalinity effects of different tree litters 2 incubated in an acid soil of N.S.W., Australia. Agrofor. Syst. 46, 147-160.

Nordén, U., 1991. Acid deposition and throughfall fluxes of elements as related to tree species in deciduous forests of South Sweden. Water Air Soil Poll. 60, 209-230.

Nordén, U., 1994. Influence of tree species on acidification and mineral pools in deciduous forest soils of South Sweden. Water Air Soil Poll. 76, 363-381.

Raulund-Rasmussen, K., Vejre, H., 1995. Effect of tree species and soil properties on nutrient immobilization in the forest floor. Plant Soil 168, 345-352.

Reich, P.B., Oleksyn, J., Modrzynski, J., Mrozinski, P., Hobbie, S.E., Eissenstat, D.M., Chorover, J., Chadwick, O., Hale, C.M., Tjoelker, M.G., 2005. Linking litter calcium, earthworm and soil properties: a common garden test with 14 tree species. Ecol. Letters 8, 811-818.

Renger, M., 1965. Berechnung der Austauschkapazität der organischen und anorganischen Anteile der Böden. Zeitschrift für Pflanzenernährung Düngung Bodenkunde 110,10-26.

Rothe, A., Binkley, D., 2001. Nutritional interactions in mixed species forests: a synthesis. Can. J. For. Res. 31, 1855-1870.

Rothe, A., Huber, C., Kreutzer, K., Weis, W., 2002a. Deposition and soil leaching in stands of Norway spruce and European beech: Results from the Höglwald research in comparison with other European case studies. Plant Soil 240, 33-45.

Saetre, P., Brandtberg, P.-O., Lundkvist, H., Bengtsson, J., 1999. Soil organisms and carbon, nitrogen and phosphorus mineralisation in Norway spruce and mixed Norway spruce - birch stands. Biol. Fertil. Soils 28, 382-388. 


\section{Chapter 2}

Sariyildiz, T., Anderson, J.M., 2005. Variation in the chemical composition of green leaves and leaf litters from three deciduous tree species growing on different soil types. For. Ecol. Manage. 210, 303-319.

Scherer-Lorenzen, M., Potvin, C., Koricheva, J., Schmidt, B., Hector, A., Bornik, Z., Reynolds, G., Schulze, E.-D. 2005. The design of experimental tree plantations for functional biodiversity research. In M. Scherer-Lorenzen, Ch. Körner \& E.-D. Schulze (Eds.), Forest Diversity and Function (pp. 347-376). Ecol. Stud. 176. Berlin, Springer, pp.347-376.

Schlichting, E., Blume, H.-P., Stahr, K., 1995. Bodenkundliches Praktikum. Pareys Studientexte 81. Blackwell Wissenschafts-Verlag, Wien, pp. 112-116.

Son, Y., Lee, I.K., 1997. Soil nitrogen mineralization in adjacent stands of larch, pine and oak in central Korea. Ann. Sci. For. 54, 1-8.

Washburn, C.S.M., Arthur, M.A., 2003. Spatial variability in soil nutrient availability in an oakpine forest: potential effects of tree species. Can. J. For. Res. 33, 2321-2330. 


\section{Chapter}

3

Productivity of temperate broad-leaved forest stands differing in tree species diversity

Mascha Jacob, Christoph Leuschner, Frank M. Thomas

(Published in: Annals of Forest Science, in press) 


\subsection{Abstract}

Understanding the effects of tree species diversity on stocks and production of tree biomass in forests is fundamental for developing strategies for carbon sequestration strategies, particularly in the perspective of the current climate change. However, the diversityproductivity relationship in old-growth forests is not well understood. We quantified biomass and above-ground production in nine forest stands with increasing tree species diversity from monocultures of beech to stands consisting of up to five deciduous tree species (Fagus sylvatica, Fraxinus excelsior, Tilia spp., Carpinus betulus, Acer spp.) to examine (a) if mixed stands are more productive than monospecific stands, (b) how tree species differ in the productivity of stem wood, leaves and fruits, and (c) if beech productivity increases with tree diversity due to a lower intraspecific competition and complementary resource use. Total above-ground biomass and wood production decreased with increasing tree species diversity. In Fagus and Fraxinus, the basal area-related wood productivity exceeded those of the co-occuring tree species, while Tilia had the highest leaf productivity. Fagus trees showed no elevated production per basal area in the mixed stands. We found no evidence of complementary resource use associated with biomass production. We conclude that aboveground productivity of old-growth temperate deciduous forests depend more on tree speciesspecific traits than on tree diversity itself.

\subsection{Introduction}

The role of plant species diversity for ecosystem processes such as biomass production, sequestration of nutrients, and the fluxes of energy and matter belongs to the most challenging topics of current ecological research, especially on the background of the current climate change (e.g. Yachi and Loreau, 2007; Fornara and Tilman, 2008). Whilst, during the past two decades, extensive studies have been conducted on the effects of plant species diversity on biomass production in grasslands (e.g. Hooper et al., 2005; Spehn et al., 2005), such studies have been performed to a much smaller extent in forest ecosystems. In theory, increased biomass production in stands that are more diverse in plant species or plant functional groups may be a consequence of positive interactions among the species or may result from complementarity in resource use, e.g., increased depletion of light, water or nutrients by coexisting plant species (e.g. Hooper and Vitousek, 1997). In forest ecosystems, most studies comparing species-poor and species-rich stands contrasted plots with one and two tree species (cf. Cannell et al., 1992). Hitherto, the number of studies on the effects of tree species diversity on tree biomass production is too small to allow general conclusions on systematic productivity differences between monospecific tree stands and stands with more than one tree species (Rothe and Binkley, 2001; Rothe et al., 2002). 
Due to the Ice Ages, the tree species diversity of Central-European forests, which - without anthropogenic interference - would be dominated by the European beech (Fagus sylvatica L.) except for very dry, wet or acidic sites and the upper montane regions, is much lower than in the temperate zones of other continents. Anthropogenic use during the past two millennia, including the establishment of fast-growing monospecific coniferous stands outside their natural habitats, has lowered tree species diversity even more. Currently, Central-European forestry is conducting a conversion of monospecific into mixed stands in part of the forested area (e.g. BMVEL 2001). However, the consequences of this conversion for productivity, biotic interactions and the fluxes of energy and matter as well as for ecosystem goods and services used by man are insufficiently known. Therefore, a long-term study on the role of biodiversity for biogeochemical cycles and biotic interactions has been established in the Hainich National Park (Thuringia, Central Germany), which is richer in tree species (up to 14 deciduous tree species per hectare) than most other forest ecosystems in Central Europe. In the context of the Hainich Tree Diversity Matrix Project, mature monospecific stands built by European beech are being compared to mature stands consisting of three or five deciduous tree species (Guckland et al., 2009; Leuschner et al., 2009). One of the foci of the study is to analyze the relationship between tree species diversity and above-ground biomass production, which is not fully understood. The results of field studies (Cannell et al., 1992; Vilà et al., 2003) and of a meta-analysis (Augusto et al., 2002) failed to yield general relationships between tree species number and production of above-ground tree biomass (Enquist and Niklas, 2001). However, a possibility not investigated so far is that the productivity of mixed stands is higher than that of pure beech stands because different tree species in mixed stands differ in their seasonal growth dynamics. In this case, complementarity would be due to temporal rather than spatial partitioning of essential resources such as light, water and nutrients, and one would expect that the productivity of European beech is higher in mixed stands than in pure beech stands. In addition, the productivity of the beech in mixed stands may be higher in pure beech stands due to the alleviation of intraspecific competition (cf. Pretzsch and Schütze, 2009). We tested these hypotheses by analyzing stem increment and biomass production of leaves and fruits, and by relating productivity to tree species diversity. This comparative study in the old-growth stands of the Hainich Tree Diversity Matrix is viewed as a complementary research approach to recently initiated experiments with planted stands differing in tree diversity (e.g. SchererLorenzen et al., 2005). 


\subsection{Materials and methods}

\section{Study area and sampling design}

We conducted the study in the Hainich National Park, Thuringia, Central Germany, in oldgrowth deciduous forest stands that differ in tree species diversity. All research sites are situated at an elevation of about $350 \mathrm{~m}$ a.s.I. near the village of Weberstedt $\left(51^{\circ} 06^{\prime} \mathrm{N}\right.$, $\left.10^{\circ} 31^{\prime} \mathrm{E}\right)$. The mean annual temperature at the Weberstedt meteorological station is $7.5^{\circ} \mathrm{C}$ and the mean annual precipitation is $670 \mathrm{~mm}$. Soils are Luvisols with a loess cover of at least $60 \mathrm{~cm}$ and stagnic properties, and are underlain by limestone (Guckland et al., 2009). The studied stands have been managed only with stem wise extraction for the past four decades and have developed a near-natural structure. A small-scale mosaic of forest ownership with different forest management systems including coppice with standards and selective tree cutting has resulted in the existence of tree species-poor and tree species-rich stands in close neighborhood (Leuschner et al., 2009).

In April 2005, forest stands differing in tree taxa diversity were selected in the north-eastern part of the national park and grouped into three diversity levels (DL): (i) four forest stands of European beech (Fagus sylvatica L.) contributing with $85 \%$ to $100 \%$ to the total tree basal area (DL 1); (ii) four stands mainly consisting of beech, lime (Tilia cordata Mill. and $T$. platyphyllos Scop.) and ash (Fraxinus excelsior L.) (DL 2); and (iii) four stands with five dominant tree taxa (beech, lime, ash, hornbeam (Carpinus betulus L.) and maple (Acer pseudoplatanus L. and A. platanoides L.)) (DL 3). The dominant trees had an average age of 85-148 years (in 2006) according to wood core analysis conducted by Schmidt et al. (2009). The plot size within a forest stand was $50 \mathrm{~m} \times 50 \mathrm{~m}$. At each $\mathrm{DL}$, all forest stands were located within a radius of about $4 \mathrm{~km}$, and were comparable with respect to slope, physical soil conditions and climatic conditions. The fenced plots also exhibited the same soil physical conditions. Their stand characteristics are presented in Table 1. 
Tab.1: Study sites description. Given are means \pm 1 SE of data from three plots. Different letters indicate significant differences between the diversity levels; $p<0.05$.

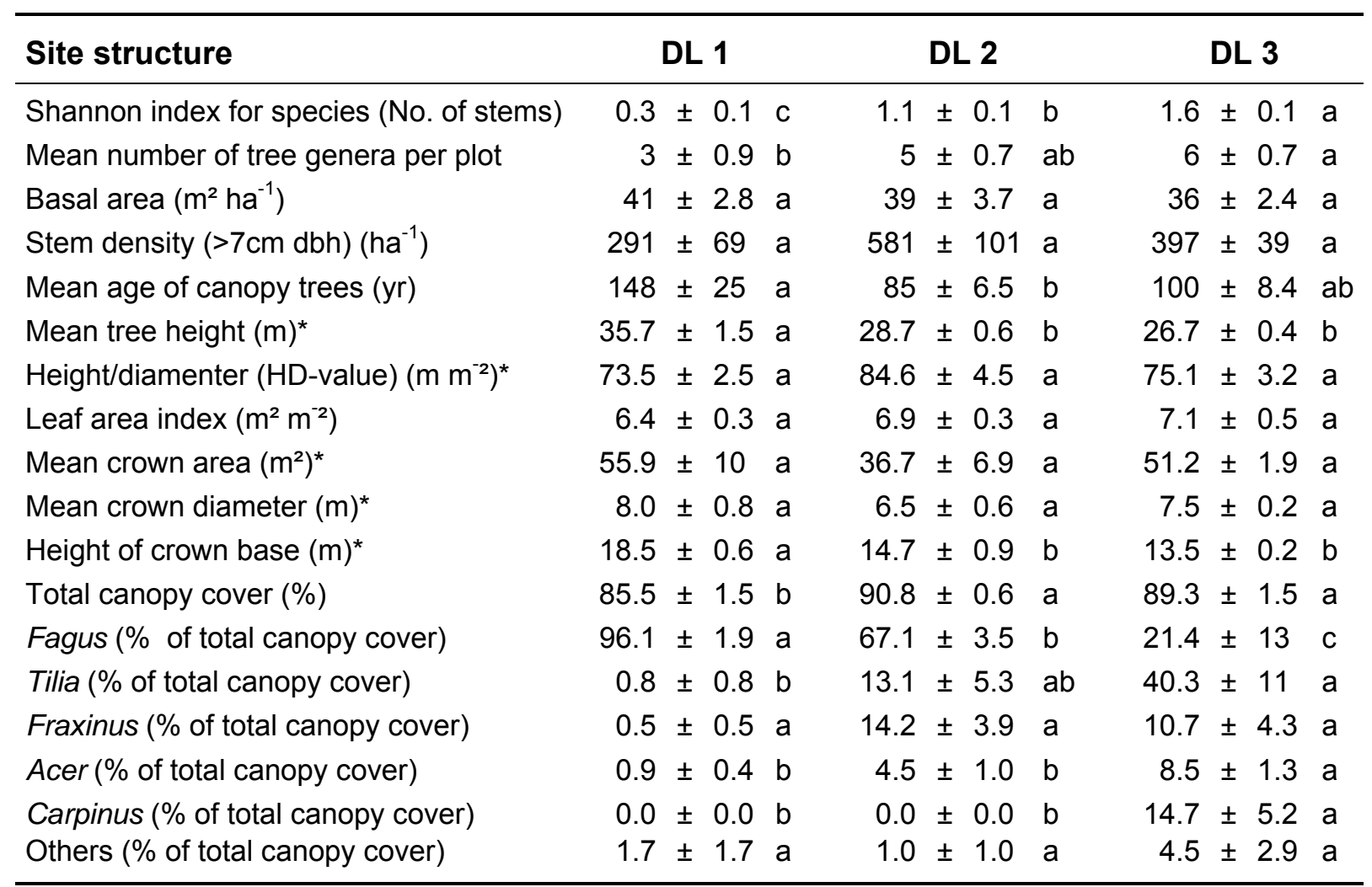

* dominant and co-dominant trees, class 1 and 2 after Kraft 1884

\section{Determination of biomass and productivity}

In summer 2005, the diameter at breast height ( $\mathrm{dbh}$ ) was recorded using measurement tapes in all trees of the 12 forest stands with a dbh exceeding $7 \mathrm{~cm}$. For all calculations, however, the values of the nine finced plots were used. In winter 2005/2006, tree height was measured using a Vertex sonic clinometer and transponder (Haglöf Sweden AB, Långsele, Sweden), and crown area was determined by 8-point canopy projection with a sighting tube equipped with a $45^{\circ}$ mirror (constructed in the Department of for Remote Sensing, University of Göttingen, Germany). Mean tree height was calculated from dominant and co-dominant trees according to class 1 and 2 after Kraft (1884) to minimize e.g. the influence of self-thinning processes or the regeneration differences of the stands. Species-specific allometric biomass equations were used to calculate above-ground woody biomass of the trees. Biomass of Fagus and Carpinus was computed using linear equations with natural logarithmic transformation based on dbh and tree height (Wirth et al., 2004):

$$
\ln (\mathrm{y})=\mathrm{a}+\mathrm{b} \cdot \ln (\mathrm{dbh})+\mathrm{c} \cdot \ln (\mathrm{dbh})^{2}+\mathrm{d} \cdot \ln (\mathrm{h})+\mathrm{e} \cdot \ln (\mathrm{h})^{2}
$$

where $y=$ biomass (kg dry mass); $a=-3.4719, b=1.90119, c=0, d=0.98218, e=0$ for stems; $a=-0.92263, b=2.68122, c=0.09993, d=-1.91638, e=0.14018$ for branches and 
twigs; $\mathrm{dbh}=$ diameter at breast height $(\mathrm{cm}), \mathrm{h}=$ tree height $(\mathrm{m})$. Total above-ground woody biomass was calculated by summing up the biomasses of stem, branches and twigs.

The woody biomass of $T$. cordata, A. pseudoplatanus, and F. excelsior was determined according to Bunce (1968) (see also Zianis et al., 2005):

$$
\ln (A B W)=a+b \cdot \ln (d b h)
$$

where $a=-2.6788$ and $b=2.4542$ in the Tilia species; $a=-2.7606$ and $b=2.5189$ in the Acer species; $a=-2.4598$ and $b=2.4882$ for $F$. excelsior; $A B W=$ above-ground woody biomass (kg dry mass), dbh = diameter at breast height $(\mathrm{cm})$. For all forest stands, the soil surface area-related woody biomass (in $\mathrm{Mg} \mathrm{ha}^{-1}$ ) was calculated.

From August 2005 to December 2007, stem diameter increment was measured at a height of $130 \mathrm{~cm}$ in all trees with $\mathrm{dbh} \geq 40 \mathrm{~cm}$ using increment measurement tapes (D1 permanent measurement tape, UP, Cottbus, Germany). Trees with a smaller dbh were assigned to two stem diameter classes ( 7 to $<20 \mathrm{~cm}$ and 20 to $<40 \mathrm{~cm}$ ), and subsamples of these classes were considered for growth increment measurements according to their share in total stem number. Annual wood production at the plot level (in $\mathrm{Mg} \mathrm{ha}^{-1} \mathrm{yr}^{-1}$ ) was calculated from the relative annual increment of wood biomass of all tree species present. Two plots (DL 1c and DL 3a) were partly destroyed by storms in summer 2006 and winter 2007/2008. These plots were excluded from the increment measurements and in these cases, wood productivity was calculated from the unfenced plots DL 1d and DL 3d.

In the nine fenced forest stands, we determined the production of leaf and fruit biomass using litter traps. In each forest stand, 15 litter collectors (aperture: $0.29 \mathrm{~m}^{2}$ ) were arranged at a minimum distance of $2 \mathrm{~m}$ along randomly positioned $30-\mathrm{m}$ transects. Water was allowed to drain from the collectors through 8-mm holes drilled through the bottom. Leaf litter was sampled every two to three weeks during September to December 2005-2007 and, additionally, once in spring and once in late summer of 2006. All samples were separated into leaves, fruits, flowers and twigs. Leaves and fruits were assigned to the different tree species, oven-dried at $70{ }^{\circ} \mathrm{C}$ for $48 \mathrm{~h}$, and weighed. Tilia cordata and T. platyphyllos were considered as one taxon as they hybridize and could not be separated into species. Soil surface area-related annual leaf production was calculated as the sum of the collected mass of leaf litter divided by the surface area of the collector. The leaves were scanned and the surface area was calculated using WinFolia software (Regent Instruments, Quebec, Canada). LAI was obtained by multiplying stand leaf biomass per species with the speciesspecific average of specific leaf area (SLA). 


\section{Statistical analyses}

Statistical data analysis and regression analyses were conducted using the software packages R, version 2.8.1 (R Development Core Team, Vienna, Austria) and SigmaPlot, version 10.0 (Systat Software Inc., San Jose, USA). To examine differences among the diversity levels ( $D L 1-3$ ) between the study years and between tree species within one diversity level, we performed an analysis of variance (ANOVA) followed by the Tukey test for all pairwise comparisons of means when assumptions of normality and homogeneity were met $(p<0.05$; Shapiro-Wilk test, Levene test). In the case of non-normally distributed data, a Kruskal-Wallis single factor analysis of variance followed by non-parametric Mann-Whitney two sample U-tests was applied ( $p<0.05$ in all analyses).

Simple regression analyses were used to analyze the relationship between tree species diversity (Shannon Index H') on the one hand, and total above-ground biomass, LAI, and variables of productivity, on the other. We conducted a multiple regression analysis after zero mean - unit variance standardisation of the explanatory variables Shannon Index H' and stand age to consider the effects of these factors on the productivity of leaves, fruits, wood and total above-ground productivity (sum of leaves, fruits and wood) simultaneously. Autocorrelation between the explanatory variables was moderate $\left(R^{2}=0.45\right)$ and the variance inflation factor of the models was considerably low (VIF $=2.046$ ). The fit of the model was checked graphically on normal distribution and heteroscedasticity of the model residuals. Akaike's Information Criterion (AIC) of each model were given.

Within a given diversity level, we performed a Kruskal-Wallis single factor analysis and nonparametric Mann-Whitney two sample U-tests to examine differences between tree species in the cumulative relative diameter growth. Trees with no basal area increment in the specific year were excluded.

\subsection{Results}

\section{Stand structure}

The forest stands of the three diversity levels (DL) did not differ significantly in basal area, stem density, height:diameter ratio (HD value), LAI, mean crown area or mean crown diameter (Table 1). Significant differences between the diversity levels existed for tree age, tree height and height of crown base, which were higher in the monospecific forest stands, and for total canopy cover. The absolute differences between the three levels were rather small, however. Thus, the forest stands were comparable with regard to fundamental characteristics of their stand and canopy structure. The differences in the tree species composition among the three $\mathrm{DL}$ are reflected by a significantly decreasing fraction of Fagus and increasing fractions of Tilia, Acer and C. betulus in the total canopy cover, and by a concomitant increase from DL 1 to DL 3 in the tree genus-related Shannon index, as calculated for tree species and based on stem numbers (Table 1). 


\section{Above-ground biomass and productivity}

The total above-ground tree biomass of the nine forest stands ranged from 200 to $480 \mathrm{Mg} \mathrm{ha}^{-1}$ (Fig. 1). The highest figure was determined in an almost pure Fagus stand. The above-ground biomass decreased significantly with increasing Shannon diversity H' of the tree layer.

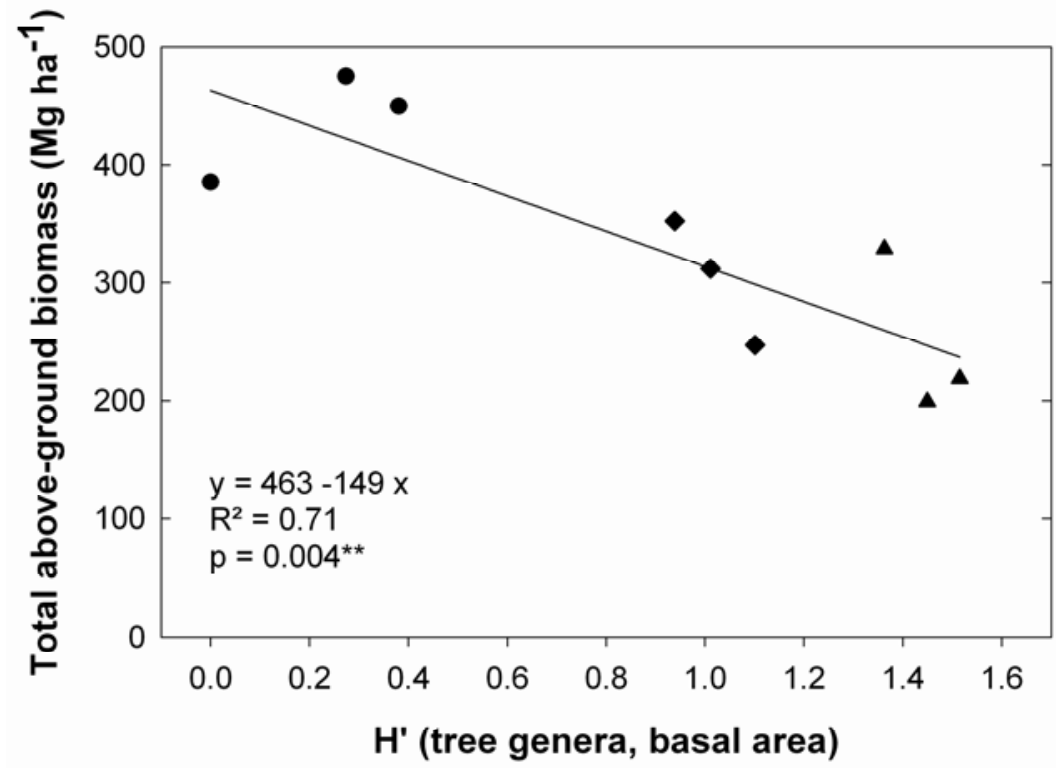

Fig. 1: Relationship between total above-ground biomass (stem and branch wood, leaves, fruits) and the Shannon Index H' of the tree layer (calculated from the basal area of all tree genera). $\mathrm{N}=3$ plots per diversity level, $\bullet \mathrm{DL} 1 ; \bullet \mathrm{DL} 2 ; \boldsymbol{\Delta} \mathrm{DL} 3$.

The production of leaves and fruits did not correlate with the tree diversity (Fig. 2). In 2006, which was a mast year in beech, the mass of produced fruits reached almost $3 \mathrm{Mg} \mathrm{ha}^{-1}$ in the DL 1 and DL 2 forest stands and, thus, was nearly as high as leaf production.

The production of wood and total above-ground biomass was highest in the pure Fagus stands and decreased with increasing tree species diversity H' (significant in 2007). The results of the regression analysis showed a higher influence of $\mathrm{H}^{\prime}$ than of stand age or the interaction of both factors on productivity measures (Tab. 2). The coefficients can be directly compared because the explanatory variables were standardised to zero mean and unit variance.

When relating the production of wood, leaves and fruits to the tree basal area instead of the plot area, a similar picture of species-specific and DL-specific production patterns appeared (Electronic supplementary material (ESM) S1) as in the plot-area related data (ESM S2). 
The calculation of the LAl allowed a year-wise comparison among DL. Mean LAl values ranged between 6.4 and $7.1 \mathrm{~m}^{2} \mathrm{~m}^{-2}$ without exhibiting significant differences among the $\mathrm{DL}$ or between the years (Tab. 1).

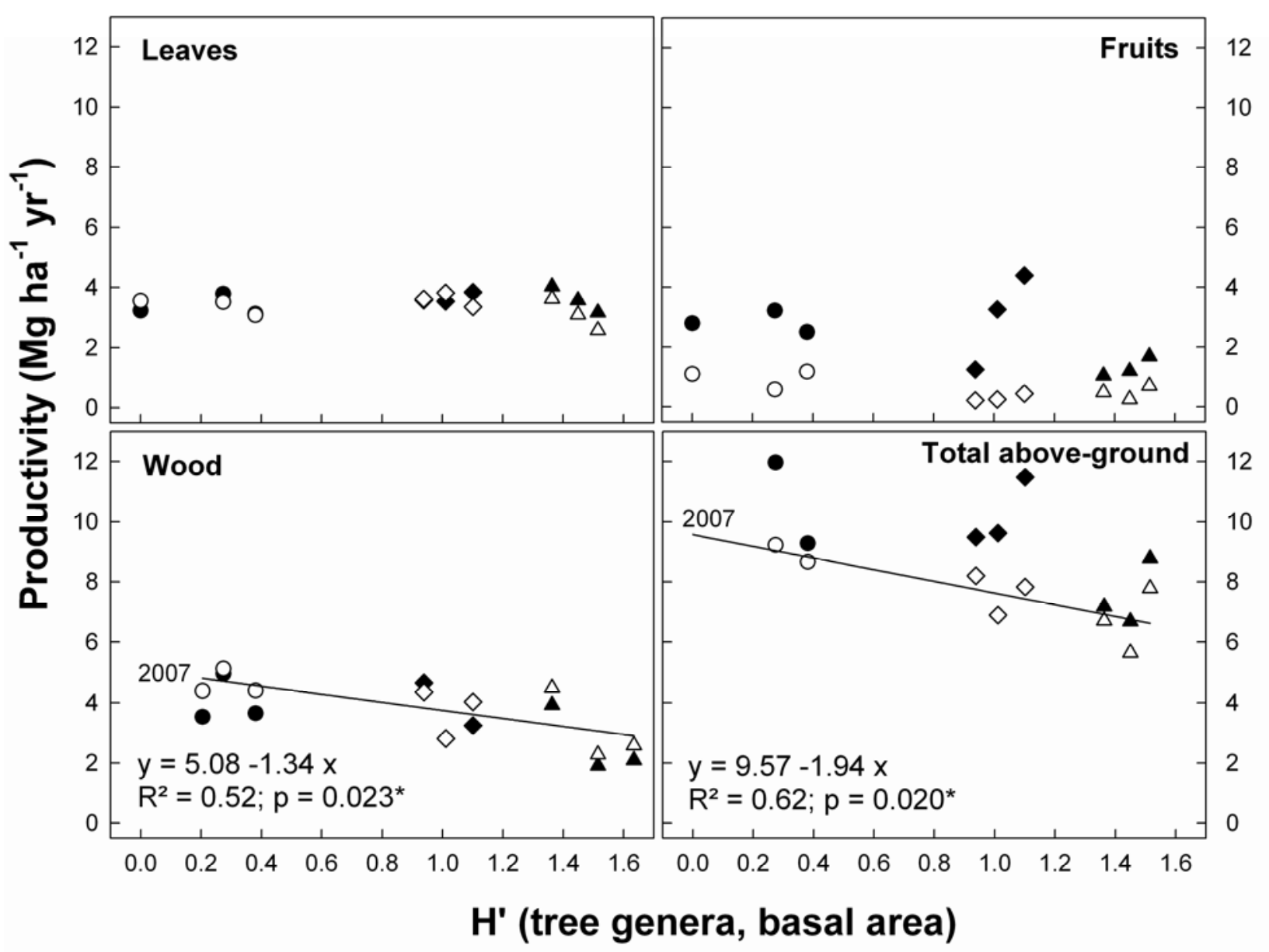

Fig. 2: Productivity of leaves, fruits, wood and total above-ground biomass plotted against the Shannon Index H' of the tree layer (calculated from the basal area of all tree genera). - DL 1; $\downarrow$ DL 2; D DL 3. Data of 2006, closed symbols; data of 2007, open symbols.

\section{Species-specific productivity}

The basal area-related production of wood, leaves and fruits of Fagus was independent from the tree species diversity H' (Fig. 3). Regarding only the dominant and co-dominant Fagus trees, the differences in the relative basal area increment were not significant among the diversity levels (Tab. 3). In the other species, the diversity level had no significant influence on the relative basal area increment as well. The highest rates of relative increment were found in Fraxinus, and lowest in Acer. 


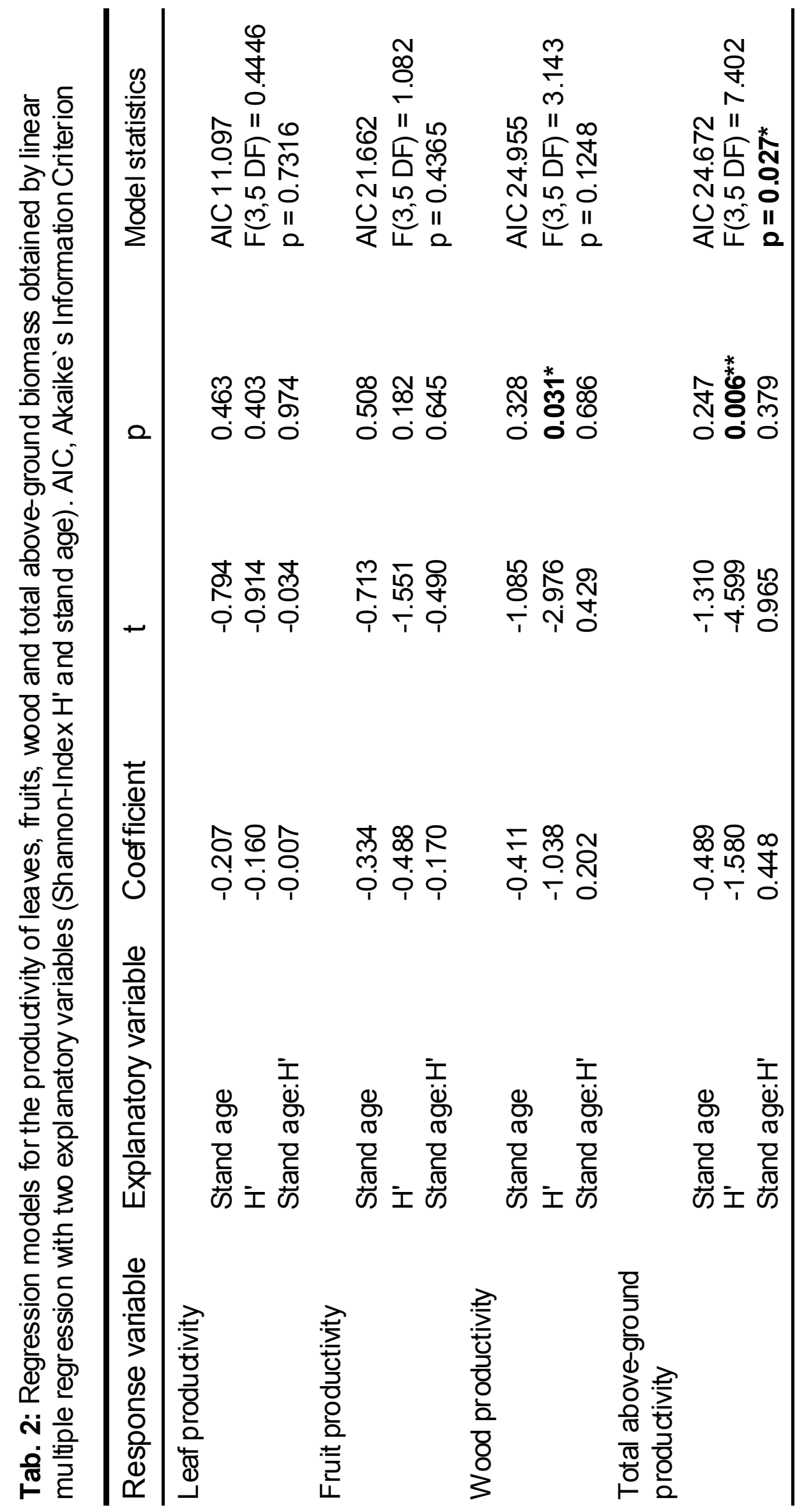


Tilia and Fraxinus occur in the mixed species forest stands of DL 2 and DL 3. Related to the basal area, Tilia produced significantly more basal area-related leaf biomass, while wood productivity of ash was significantly higher compared to the other species (Fig. 4). In the mast year of 2006, only Carpinus reached values of fruit production that were similar to those of Fagus (ESM S2).

The relative basal area increment of dominant and co-dominant Fagus trees tended to be higher at DL 2 and DL 3 than in DL 1, but the differences were not significant (Table 4). In the other species, the diversity level had no significant influence on relative basal area increment as well. The highest rates of relative increment were found in Fraxinus, and the lowest in Acer.

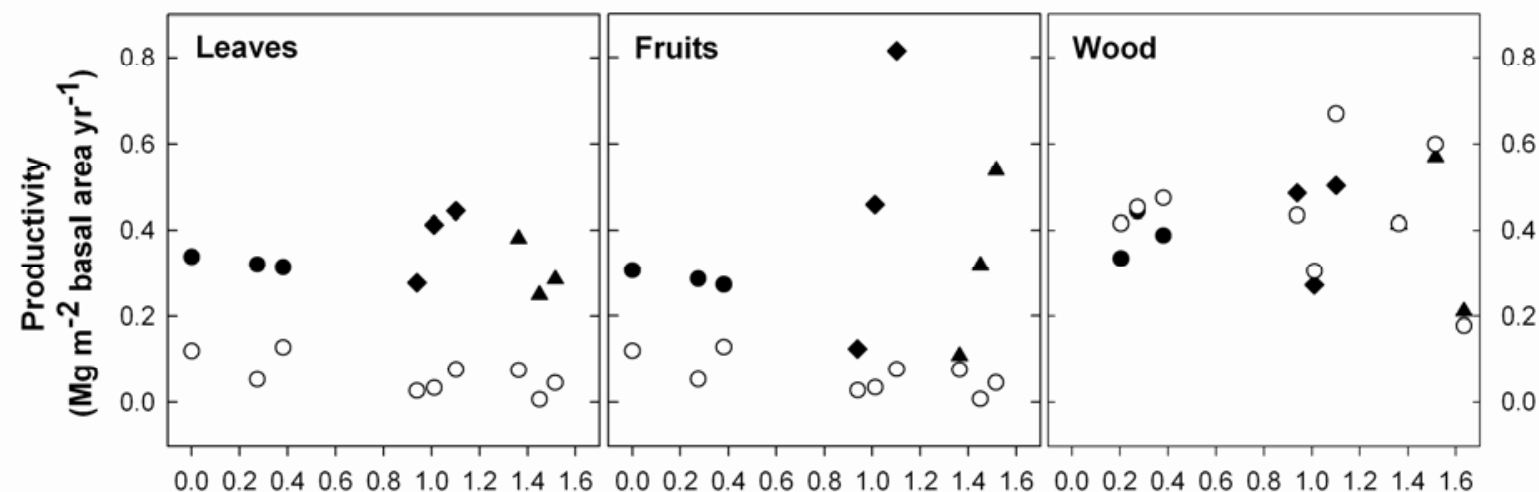

\section{H' (tree genera, basal area)}

Fig. 3: Relationship between the basal area-related productivity of leaves, fruits, and wood in Fagus sylvatica and the Shannon Index H' of the tree layer (calculated from the basal area of all tree genera).

- DL 1; DL 2; A DL 3. Data of 2006, closed symbols; data of 2007, open symbols.

Tab. 3: Relative basal area-increment of dominant and co-dominant trees (in $\% \mathrm{yr}^{-1}$ ) (means $\pm 1 \mathrm{SE}$ of data from 3 plots). Different lower-case letters indicate significant differences between the three diversity levels, capital letters indicate significant differences between different years.

\begin{tabular}{lcccccc}
\hline & \multicolumn{2}{c}{ DL 1 } & \multicolumn{2}{c}{ DL 2 } & \multicolumn{2}{c}{ DL3 } \\
& 2006 & 2007 & 2006 & 2007 & 2006 & 2007 \\
\hline Fagus sylvatica & $0.90 \pm 0.11$ & $1.08 \pm 0.07$ & $1.25 \pm 0.23$ & $1.47 \pm 0.24$ & $1.01 \pm 0.23$ & $1.11 \pm 0.18$ \\
& $\mathrm{a} \mathrm{A}$ & $\mathrm{a} \mathrm{A}$ & $\mathrm{a} \mathrm{A}$ & $\mathrm{a} \mathrm{A}$ & $\mathrm{a} \mathrm{A}$ & $\mathrm{a} \mathrm{A}$ \\
Fraxinus excelsior & & & $1.92 \pm 0.24$ & $1.67 \pm 0.06$ & $1.78 \pm 0.33$ & $2.04 \pm 0.20$ \\
& & & $\mathrm{a} \mathrm{A}$ & $\mathrm{a} \mathrm{A}$ & $\mathrm{a} \mathrm{A}$ & $\mathrm{a} \mathrm{A}$ \\
Tilia sp. & & & $0.69 \pm 0.24$ & $1.12 \pm 0.12$ & $0.80 \pm 0.09$ & $1.43 \pm 0.15$ \\
& & & $\mathrm{a} \mathrm{A}$ & $\mathrm{a} \mathrm{A}$ & $\mathrm{a} \mathrm{A}$ & $\mathrm{a} \mathrm{B}$ \\
Acer sp. & & & & $0.57 \pm 0.17$ & $0.76 \pm 0.25$ \\
& & & & & $\mathrm{~A}$ & $\mathrm{~A}$ \\
Carpinus betulus & & & & & $0.89 \pm 0.22$ & $0.92 \pm 0.33$ \\
& & & & & & $\mathrm{~A}$ \\
\hline
\end{tabular}




\section{Seasonal course of biomass production}

The seasonal course of the basal area-related cumulative stem increment ("cumulative relative diameter increment", CDI) demonstrates different growth dynamics of the individual species during each vegetation period (Fig.5). In 2006, when cool and humid weather predominated until the beginning of June, the trees exhibited sigmoid increment curves with the largest increment between June and August. One exception is Fraxinus showing a saturation curve with maximum growth rates already occurring between April and June. In the year 2007, which was characterized by an exceptionally warm and dry April, we detected near-linear increments from April to June or August in all tree species.

In Fagus, CDI was significantly lower from April to June than in Fraxinus (Fig. 5). From April to June 2006, CDI was significantly lower in Acer than in all other investigated tree genera. In that year, Acer, Carpinus, Tilia and Fagus displayed a steep increase in CDI from June to August. The rapid diameter increase in Tilia partly was caused by a decrease in diameter from April to June 2006. In 2007, we find very similar growth patterns in Fagus and Tilia as well as in Carpinus and Acer.

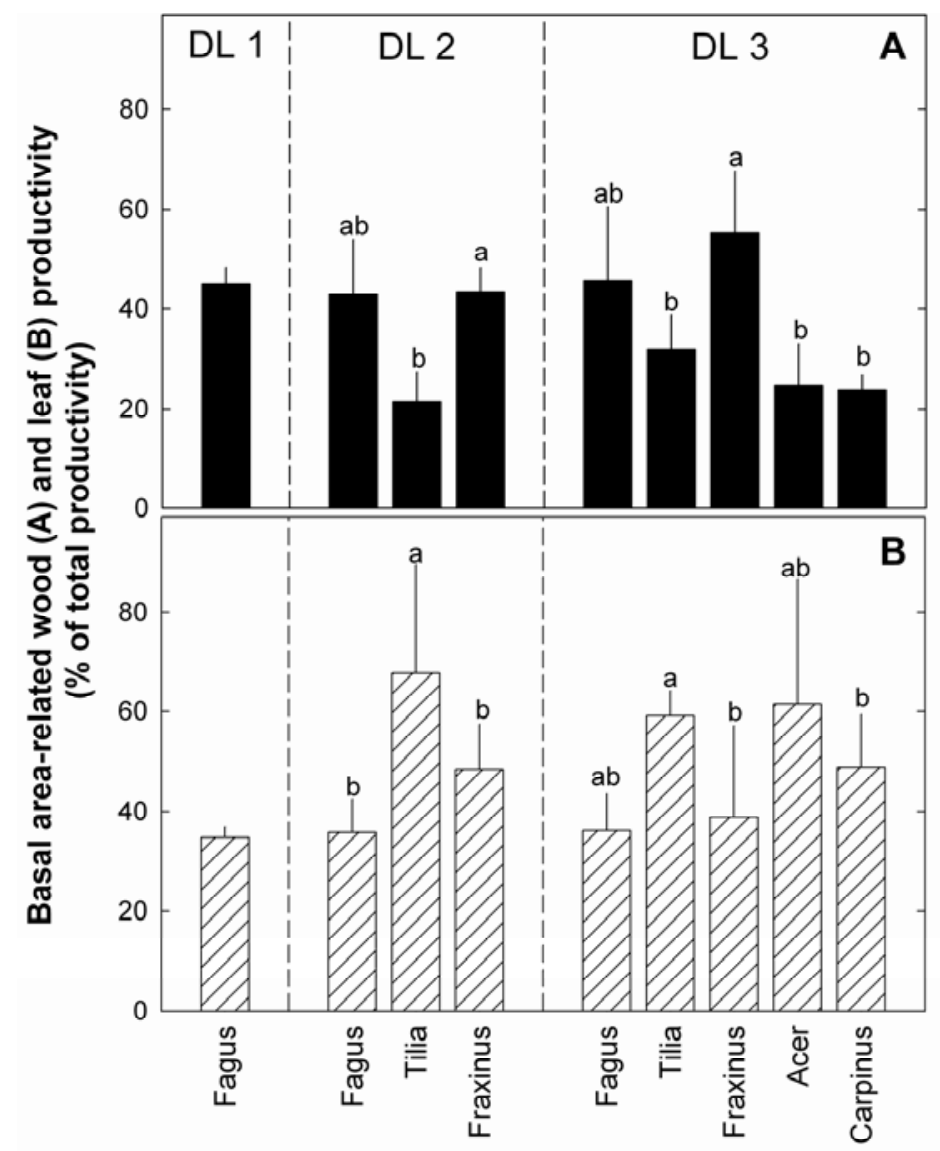

Fig. 4: Basal area-related leaf and wood productivity in \% of total above-ground productivity. Given are mean values of 2006 and 2007 and standard error $(N=3)$. Significant differences between species in one diversity level are indicated with small Latin letters. 

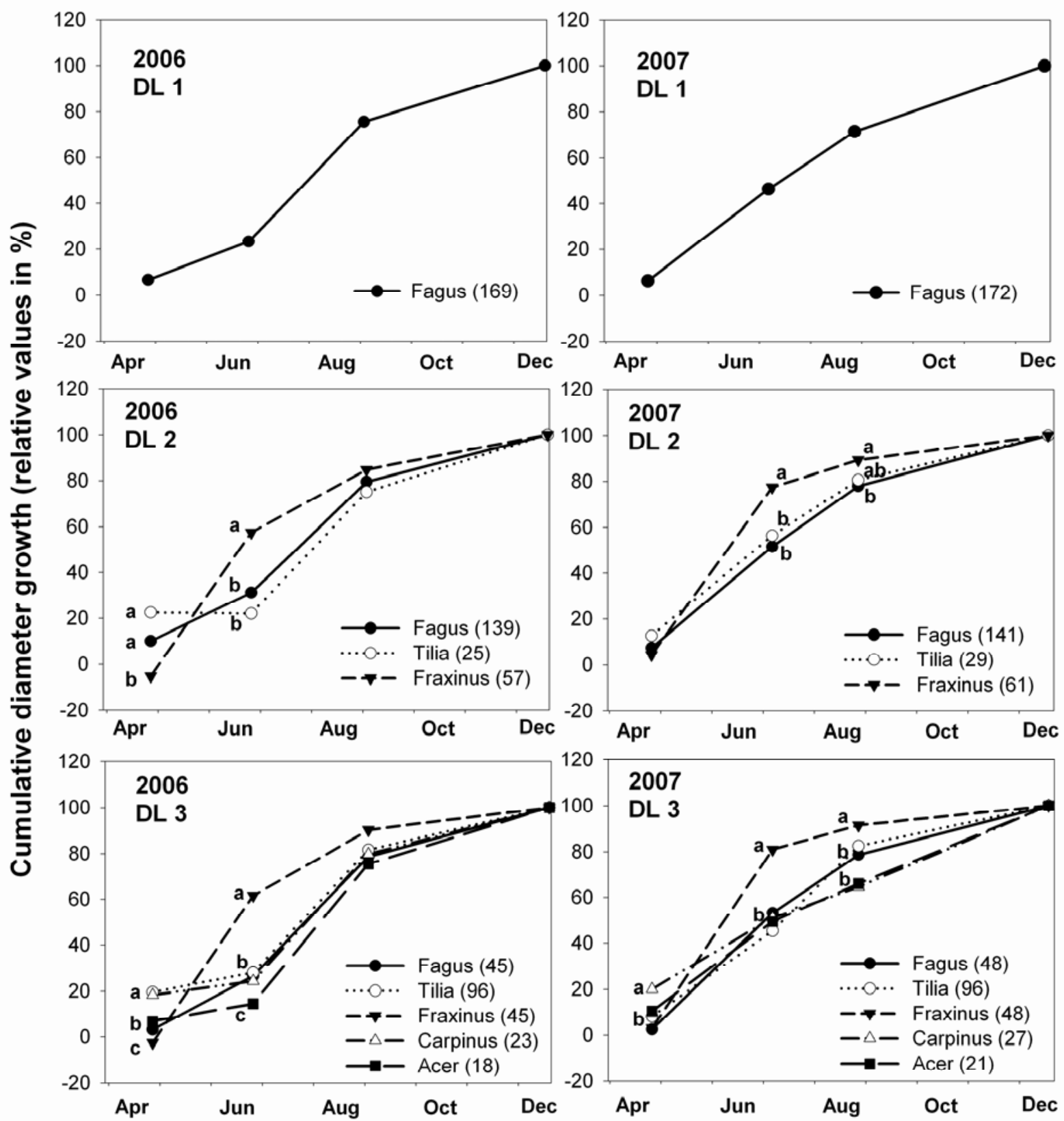

Fig. 5: Relative cumulative seasonal diameter growth for the dominant species in the three diversity levels in the year 2006 and 2007. Significant differences between species in one diversity level are indicated with small Latin letters. The number of trees per diversity level is shown in brackets. 


\subsection{Discussion}

In nine old-growth forest stands with increasing tree species diversity of broad-leaved Central-European tree species, we found no increase in above-ground productivity with increasing tree species diversity. Rather, there was a decline of wood and total aboveproductivity with increasing diversity of tree genera. This finding is in contrast to the results of several other studies on forests. Whilst model simulations predict that the productivity of mixed stands will generally be intermediate between that of the respective monospecies stands (Bartelink, 2000), field studies revealed that, compared to monospecies stands, the productivity of mixed stands can decrease or increase by up to $30 \%$, depending on the specific physiology and growth potential of the species (Pretzsch, 2005). In Southern Germany, mixed stands of Fagus sylvatica and Picea abies produced up to $59 \%$ more above-ground biomass than adjacent pure stands (Pretzsch and Schütze, 2009). The authors explained this finding by a reduction in intraspecific competition among Fagus trees (which, for beech, is more severe than interspecific competition with spruce), and by facilitation brought about by Fagus to the benefit of Picea through an improvement of nutrient supply by deeper soil exploitation, higher nutrient turnover, and activation of the humus layer.

In contrast, wood production did not differ significantly among monospecies and mixed forests dominated by Pinus sylvestris or P. halepensis in Southeastern Spain when environmental factors, such as climate, bedrock types, and radiation were included in the analysis (Vilà et al., 2003). However, in early-successional Mediterranean-type forests in Northeastern Spain, Vilà et al. (2007) detected a significant increase of wood production with increasing tree species richness across a broad range of environmental conditions. Agedependent growth patterns of juniper woodlands in Spain result from differences in the management system. Rozas et al. (2008) found that Juniper productivity did change abruptly with the transformations of the traditional management system. A livestock decrease, however, could also have led to higher plant species diversity. Most differences observed in above-ground productivity among forest stands differing in tree species richness could be attributed to species-specific traits or contrasting site conditions rather than to the number of tree species present (Kerr et al., 1992; Vilà et al., 2003; Pretzsch, 2005; Sánchez-Gómez et al. 2008).

The decline of wood productivity with increasing diversity of tree genera of our study is probably related to the observed decrease in total above-ground tree biomass. Similar results were obtained in a study conducted in a variety of unmanaged forest stands in the Czech Republic, Poland and Slovakia, which covered stands composed of one to eight tree species (Szwagrzyk and Gazda, 2007). That study revealed a negative (yet insignificant) 
trend of above-ground biomass with increasing tree species richness within a range of above-ground biomass (169-536 $\mathrm{Mg} \mathrm{ha}^{-1}$ ) that was similar to our study (200-480 Mg ha ${ }^{-1}$ ). With regard to biomass accumulation by Fagus sylvatica, the results obtained in the study by Szwagrzyk and Gazda (2007) fit our findings well: the share of beech was positively correlated with biomass accumulation, and the highest above-ground biomass was found in pure stands of Fagus. However, in our study, this result cannot be explained by the "sampling effect", i.e. the effect that the most productive species of a given community determines the level of productivity (cf. Hooper et al., 2005). In our study, the trend towards a higher biomass in the pure beech stands could be due to the increased tree age of the canopy trees. However, multiple regression analysis revealed a higher influence of the tree diversity compared to stand age or the interaction of both factors. Furthermore, the higher biomass accumulation in beech stands cannot be attributed to a better nutrient supply: compared to the mixed species stands, the Fagus stands exhibited a significantly lower soil $\mathrm{pH}$ and base saturation, and tended towards a lower cation exchange capacity and higher C:N ratios (Guckland et al., 2009), which is believed to be mainly a result of Fagus leaf and root litter effects on the soil.

In the investigated forest stands, the annual production of wood and leaves was similar to that of a highly diverse (eight predominating tree species) mesic temperate deciduous forest in the Southeast of North America (Newman et al., 2006). In contrast to Newman et al. (2006), the total production of wood and leaves in our study did not differ significantly in most cases, despite distinct differences in the weather conditions between the study years. The increase in the leaf area index ( $\mathrm{LAl}$ ) with increasing tree species diversity can be explained with a larger biomass investment into the leaves (compared to wood) in Tilia, Carpinus and Acer that, in addition, also display a high specific leaf area (SLA) (data on request).

Different tree species are capable of using the water and nutrient resources from the soil in a complementary manner due to differences in root architecture (cf. Köstler et al., 1968; Polomski and Kuhn, 1998; Kutschera and Lichtenegger, 2002). In the present study, we did not find such positive effects of complementarity on the production and accumulation of biomass as there were no significant species differences in rooting patterns among the three diversity levels (Meinen, 2009). Complementarity could also be possible with regard to temporal differences in the use of below-ground or above-ground resources. In the mixed species forest stands of our study, Fraxinus had reached $60-80 \%$ of its annual increment in basal area already at the end of June, whereas the seasonal growth dynamics of Tilia seemed to be more dependent on the weather: growth of Tilia was slow in the cool and moist spring of 2006, but much faster in the warm spring of 2007. Fraxinus, the only ring-porous 
tree species of our study, leaves out later than the other tree species. Therefore, its early stem growth cannot be explained by higher photosynthesis rates but rather by the formation of early wood and of the main conducting vessels for water transport (Leuschner et al., in revision).

The growth of Fagus was slower than that of Fraxinus in the mixed forest stands. Most likely, rapid early stem growth of Fraxinus can be tolerated by Fagus because the slender crowns of Fraxinus, which can utilize even small gaps within a closed forest stand, only have a small shading effect on the surrounding trees. On the other hand, Fagus is competitively superior to other Central European deciduous forest tree species due to its higher shade tolerance in juvenile stages (Ellenberg, 1996), its low crown transmissivity of photosynthetically active radiation that causes severe shading of competing species (Leuschner, 1998), and its capability of efficiently exploring the crown space by its foliage mass and its annual branch volume increment (Reiter et al., 2005). However, differential seasonal growth patterns among the species did not result in increased productivity at the plot level compared to the monospecific stands.

We summarize that above-ground productivity of the investigated mature temperate deciduous forest stands is remarkably constant not only for different levels of tree species diversity but also over subsequent years, if water availability is sufficient. Tilia, Acer and Carpinus invest a large fraction of carbon into the production of foliage and, thus, enhance carbon cycling in mixed species stands, whereas the production of stem wood in Fagus trees exceeds leaf production and results in longer carbon storage in monospecific stands. Our data suggest that above-ground net primary production is much more under the control of climate and edaphic factors than dependent on tree species diversity. Furthermore, characteristic physiological, morphological and architectural traits, which control productivity, seem to be more influential than the mere number of species present.

\section{Acknowledgements}

We thank the German Research Council (DFG) for funding within the Research Training Group (Graduiertenkolleg) 1086. Many colleagues from the Research Training Group supported our studies with data and comments. 


\subsection{References}

Augusto L., Ranger J., Binkley D., Rothe A., 2002. Impact of several common tree species of European temperate forests on soil fertility. Ann. For. Sci. 59: 233-253.

Bartelink H.H., 2000. Effects of stand composition and thinning in mixed-species forests: a modeling approach applied to Douglas-fir and beech. Tree Physiol 20: 399-406.

BMVEL, 2001. Gesamtwaldbericht der Bundesregierung. BMVEL (Bundesministerium für Verbraucherschutz, Ernährung und Landwirtschaft), Bonn, $141 \mathrm{p}$.

Bunce R.G.H., 1968. Biomass and production of trees in a mixed deciduous woodland: I. Girth and height as parameters for estimation of tree dry weight. J Ecol 56: 759-775.

Cannell M.G.R., Malcolm D.C., Robertson P.A. (Eds.), 1992. The ecology of mixed-species stands of trees. Blackwell, Oxford, $312 \mathrm{p}$.

Ellenberg H., 1996. Vegetation Mitteleuropas mit den Alpen, Ulmer, Stuttgart, 981 p.

Enquist B.J., Niklas K.J., 2001. Invariant scaling relations across tree-dominated communities. Nature 410: 655-660.

Fornara D.A., Tilman D., 2008. Plant functional composition influences rates of soil carbon and nitrogen accumulation. J Ecol 9: 314-322.

Guckland A, Jacob M, Flessa H, Thomas FM, Leuschner C. 2009. Acidity, nutrient stocks, and organic-matter content in soils of a temperate deciduous forest with different abundance of European beech (Fagus sylvatica L.). J Plant Nut Soil Sci, 172:500-511.

Hooper D.U., Chapin F.S., Ewel J.J., Hector A., Inchausti P., Lavorel S., Lawton J.H., Lodge D.M., Loreau M., Naeem S., Schmid B., Setälä H., Symstad A.J., Vandermeer J., Wardle D.A., 2005. Effects of biodiversity on ecosystem functioning: A consensus of current knowledge. Ecol Monogr 75: 3-35.

Hooper D.U., Vitousek P.M., 1997. The effects of plant composition and diversity on ecosystem processes. Science 277: 1302-1305.

Kerr G., Nixon C.J., Matthews R.W., 1992. Silviculture and yield of mixed-species stands: the UK experience. In: Cannell M.G.R., Malcolm D.C., Robertson P.A. (Eds). The ecology of mixed-species stands of trees. Oxford: Blackwell Oxford, pp. 35-51. 
Kraft G., 1884. Beiträge zur Lehre von den Durchforstungen, Schlagstellungen und Lichtungshieben. Klindworth's Verlag, Hannover.

Köstler J.N., Brückner E., Bibelriether H., 1968. Die Wurzeln der Waldbäume. Parey, Hamburg, 284 p.

Kutschera L., Lichtenegger E., 2002. Wurzelatlas mitteleuropäischer Waldbäume und Sträucher. Leopold Stocker Verlag, Graz, 604 p.

Leuschner C., 1998. Mechanismen der Konkurrenzüberlegenheit der Rotbuche. Berichte der Reinhold-Tüxen-Gesellschaft 10: 5-18.

Leuschner C., Gebauer T., Horna V., 2009. Canopy transpiration in temperate broad-leaved forests of low, moderate and high tree species diversity. In revision.

Leuschner C., Jungkunst H., Fleck S., 2009. Functional role of forest diversity: Pros and cons of synthetic stands and across-site comparisons in established forests. Basic Appl. Ecol. 10, 1-9.

Lindner M., Karjalainen T., 2007. Carbon inventory methods and carbon mitigation potentials of forests in Europe: a short review of recent progress. Eur J Forest Res 126: 149-156.

Meinen C.,Hertel D., Leuschner C., 2009. Biomass and morphology of fine roots in temperate broad-leaved forests differing in tree species diversity: is there evidence of below-ground overyielding? Oecologia, 161:99-11.

Newman G.S., Arthur M.A., Muller R.N., 2006. Above- and belowground net primary production in a temperate mixed deciduous forest. Ecosystems 9: 317-329.

Pretzsch H., 2005. Diversity and productivity in forests: evidence from long-term experimental plots. In: Scherer-Lorenzen M., Körner Ch., Schulze E.D. (Eds). Forest Diversity and Function - Temperate and Boreal Systems. Ecological Studies 176. Berlin: Springer Berlin, pp. 41-64.

Pretzsch H., Schütze G., 2009. Transgressive overyielding in mixed compared with pure stands of Norway spruce and European beech in Central Europe: evidence on stand level and explanation on individual tree level. Eur J Forest Res 128:183-204.

R Development Core Team, 2008. R: A language and environment for statistical computing. R Foundation for Statistical Computing, Vienna, Austria. ISBN 3-900051-07-0, URL http://www.R-project.org. 
Reiter I.M., Häberle K.H., Nunn A.J., Heerdt C., Reitmayer H., Grote R., Matyssek R., 2005. Competitive strategies in adult beech and spruce: space-related foliar carbon investment versus carbon gain. Oecologia 146: 337-349.

Rothe A., Binkley D., 2001. Nutritional interactions in mixed species forests: a synthesis. Can J Forest Res 31: 1855-1870.

Rothe A., Kreutzer K., Küchenhoff H., 2002. Influence of tree species composition on soil and soil solution properties in two mixed spruce-beech stands with contrasting history in Southern Germany. Plant Soil 240: 47-56.

Rozas V., Olano J.M., De Soto L., Bartolomé D., 2008. Large-scale structural variation and long-term growth dynamics of Juniperus thurifera trees in a managed woodland in Soria, central Spain. Ann. For. Sci. 65:809p1-809p10

Sánchez-Gómez D., Zavala M.A., Van Schalkwijk D.B., Urbieta I.R., Valladares F., 2008. Rank reversals in tree growth along tree size, competition and climatic gradients for four forest canopy dominant species in Central Spain. Ann. For. Sci. 65:605p1-605p9

Scherer-Lorenzen M., Körner Ch., Schulze E.D., 2005. The functional significance of forest diversity: a synthesis. In: Scherer-Lorenzen M., Körner Ch., Schulze E.D. (Eds). Forest Diversity and Function - Temperate and Boreal Systems, Ecological Studies 176, Springer Berlin, pp. 377-389.

Schmidt I., Leuschner C., Mölder A., Schmidt W., 2009. Structure and composition of the seed bank in monospecific and tree species-rich temperate broad-leaved forests. Forest Ecology and Management, 257: 695-702.

Spehn E.M., Hector A., Joshi J., Scherer-Lorenzen M., Schmid B., Bazeley-White E., Beierkuhnlein C., Caldeira M.C., Diemer M., Dimitrakopoulos P.G., Finn J.A., Freitas H., Giller P.S., Good J., Harris R., Högberg P., Huss-Danell K., Jumpponen A., Koricheva J., Leadley P.W., Loreau M., Minns A., Mulder C.P.H., O'Donovan G., Otway S.J., Palmborg C., Pereira J.S., Pfisterer A.B., Prinz A., Read D.J., Schulze E.D., Siamantziouras A.S.D., Terry A.C., Troumbis A.Y., Woodward F.I., Yachi S., Lawton J.H., 2005. Ecosystem effects of biodiversity manipulations in European grasslands. Ecol Monogr 75: 37-63.

Szwagrzyk J., Gazda A., 2007. Above-ground standing biomass and tree species diversity in natural stands of Central Europe. J Veg Sci 18: 555-562.

Vilà M., Vayreda J., Gracia C., Ibáñez J.J., 2003. Does tree diversity increase wood production in pine forests? Oecologia 135: 299-303. 
Chapter 3

Vilà M., Vayreda J., Comas L., Ibáñez J.J., Mata T., Obón B., 2007. Species richness and wood production: a positive association in Mediterranean forests. Ecol Lett 10: 241-250.

Wirth C., Schulze E.D., Schwalbe G., Tomczyk S., Weber G., Weller E., 2004. Dynamik der Kohlenstoffvorräte in den Wäldern Thüringens. Thüringer Landesanstalt für Wald, Jagd und Fischerei, Mitteilungen 23/2004. Gotha.

Yachi S., Loreau M., 2007. Does complementary resource use enhance ecosystem functioning? A model of light competition in plant communities. Ecol Lett 10: 54-62.

Zianis D., Muukkonen P., Mäkipää R., Menuccini M., 2005. Biomass and stem volume equations for tree species in Europe. Silva Fenn Monogr 4. 


\section{Supplementary material}




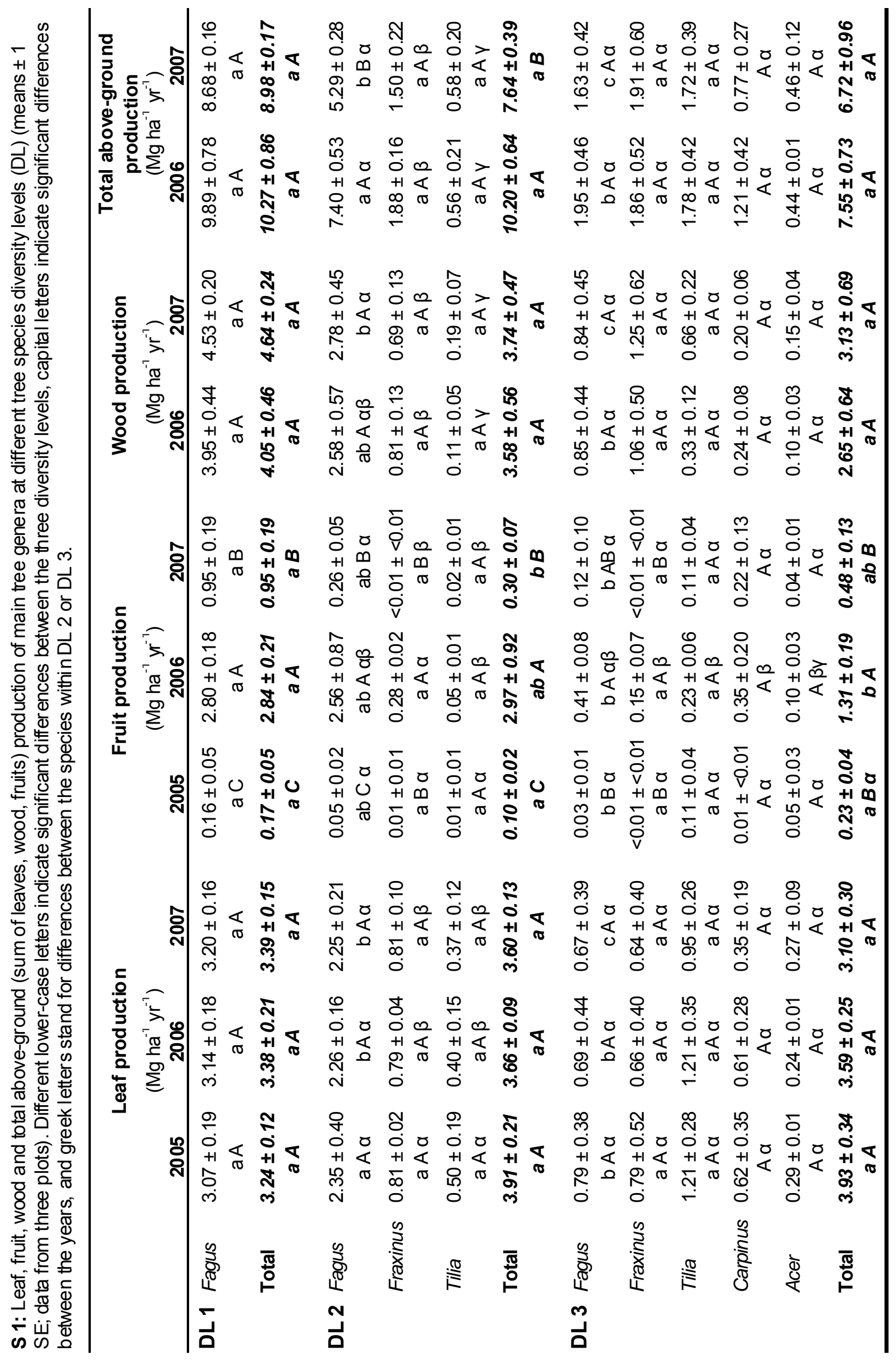




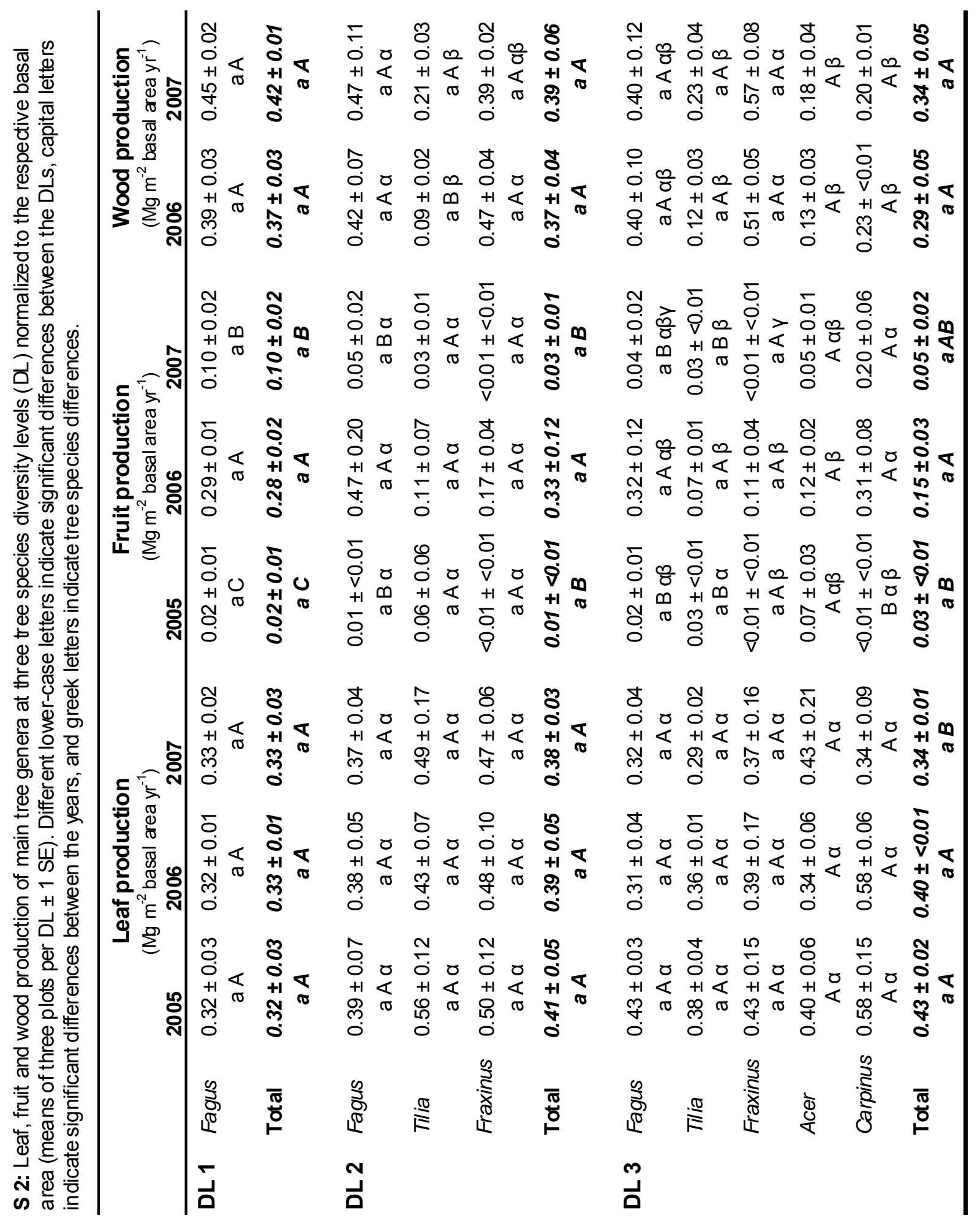


- 70 - 


\section{Chapter \\ 4}

\section{Leaf litter decomposition in temperate deciduous forest stands along a gradient of increasing tree species diversity}

Mascha Jacob, Karin Viedenz, Andrea Polle, Frank M. Thomas

(In revision) 


\subsection{Abstract}

We hypothesised that the decomposition rates of leaf litter will increase along a gradient of increasing tree species diversity in the generally bech-dominated Central-European temperate deciduous forests due to an increase in the quality of the litter. We studied the decomposition of litter and lignin in stands composed of European beech (Fagus sylvatica; DL 1); beech, ash (Fraxinus excelsior L.) and lime (Tilia spp.) (DL 2); or beech, ash, lime, maple (Acer spp.) and hornbeam (Carpinus betulus L.) (DL 3) for up to 22 months. We measured mass loss from mesh bags filled with representative bulk litter (MIX bags) from stands DL 1, DL 2 or DL 3. In addition, we incubated bags containing litter from only one of the five tree species (MONO bags) in replicated plots at all diversity levels. In the MIX bags, litter and lignin decomposition was faster at DL 2 and DL 3 than at DL 1. In the MONO bags, litter and lignin decomposition of the individual species litter (except for beech) did not differ among DL, but was most rapid in ash and slowest in beech in an interspecific comparison. In the litter mixtures, decomposition was not significantly more rapid than predicted by MONO bags. Leaf litter decomposition rates were positive correlated with the initial $\mathrm{N}$ and $\mathrm{Ca}$ concentrations of the litter, and negatively, with the initial $\mathrm{C}: \mathrm{N}, \mathrm{C}: \mathrm{P}$ and lignin: $\mathrm{N}$ ratios, but not with the initial lignin concentrations. The results support our hypothesis that the decomposition rates are controlled by the chemical composition of the individual litter species and not by synergistic effects assignable to mixtures of litter composed of different tree species. Thus, the presence of individual tree species in an ecosystem seems to be more important for the litter decomposition rates than the tree species diversity itself.

\subsection{Introduction}

The significance of plant species diversity for ecosystem functions is a central issue in current ecological research (Hooper et al. 2005; Balvanera et al. 2006). To date most studies have focused on diversity-productivity relationships in experimental grasslands or forest plantations (Scherer-Lorenzen et al. 2005; Spehn et al. 2005). In these studies, positive relationships have generally been found between primary productivity and plant-species diversity (Hooper et al. 2005; Spehn et al., 2005). Less is known on biodiversity effects on other key ecosystem processes such as decomposition and nutrient cycling. The decomposition process of plant litter controls the release of essential plant nutrients such as nitrogen $(\mathrm{N})$ and, thereby, exerts a large influence on the growth rates of plant species (e.g., Cotrufo et al. 2000; Parton et al. 2007).

Most studies on litter decomposition in forests have included only two or three tree litter species and compared monocultures with just one mixing treatment. According to 
Hättenschwiler et al. (2005), this narrow range of methodical approaches strongly limits the thorough assessment of diversity effects and is one reason why generalisations of litter-mass loss as a function of litter diversity are not yet possible.

A substantial fraction of studies performed indicates that mass loss from various litter mixtures is more rapid than would have been predicted from the decay rates of the individual species included in the mixture. Accordingly, it exhibits non-additive characteristics, which is in contrast to additive responses that can be predicted from the decay of the individual litter species (Gartner \& Cardon 2004). The potential mechanisms underlying the non-additive effects result from the different physical and chemical traits of litter species such as leaf toughness, the concentrations of nutrients and lignin, and lignin:nutrient ratios (Hättenschwiler et al. 2005). The decomposition of litter from deciduous woody species of temperate regions was non-additive in its $\mathrm{N}$ dynamics, but was additive in its mass loss (Ball et al. 2008). To date, however, no general pattern of litter-diversity effects on the mass loss from litter during decomposition has emerged (e.g., Wardle et al. 1997; Wardle et al. 2009).

Effects exerted by litter mixtures can be influenced by the quality of the component litter species (e.g., Meier \& Bowman 2008). In general, decomposition rates increase with a decrease in the ratio of carbon to $\mathrm{N}$ (C:N ratio), which is therefore an important indicator of litter quality (e.g., Heal et al. 1997). Another constituent limiting the rate of litter degradation is lignin (e.g., Melillo et al. 1982; Osono \& Takeda 2005), a complex aromatic heteropolymer in cell walls (Boerjan et al. 2003), which is one of the litter components that are most recalcitrant to decomposition (Osono 2007, Berg \& McClaugherty 2008). Therefore, not only the species mixture of the litter per se, but also the presence or absence of individual litter species can influence the decomposition rate within a mixture.

In temperate forests, several studies have already been conducted on the effects of litter diversity on litter decomposition (cf. Gartner \& Cardon 2004; Hättenschwiler et al. 2005), but investigations covering a broader gradient of deciduous tree species including the European beech (Fagus sylvatica L.), the predominant tree species in the temperate deciduous forests of Central Europe (e.g., Ellenberg 1996), are relatively scarce. As a consequence of land use history, monospecific stands with beech, whose litter exhibits slow decomposition rates (e.g., Wise \& Schaefer 1994, Hättenschwiler \& Gasser 2005), are abundant in Central Europe. In beech forests, silvicultural management programs attempt to increase the fractions of other broad-leaved tree species such as ash (Fraxinus excelsior L.), lime (Tilia spp.), maple (Acer spp.) and hornbeam (Carpinus betulus L.). However, the effects of elevated tree species 
diversity on leaf litter decomposition and the ecosystem fluxes of carbon and mineral nutrients still are largely unknown.

To investigate whether litter decomposition in Central European forests is controlled by tree identity or diversity, we investigated mass loss, lignin and nutrient element composition in litter mixtures of one (beech), three (beech, ash, lime) and five tree species (beech, ash, lime, hornbeam, maple) as well as in single-species litter samples incubated on-site in litterbags. The study was performed in a temperate deciduous forest of Central Germany, which is exceptionally rich in tree species (up to 14 species per hectare) compared to the majority of Central European forests that are poor in tree species due to the impact of the ice age. We hypothesised that the decomposition rates of (i) stand-specific litter mixtures and (ii) of litter of the individual tree species increase along the gradient of increasing tree species diversity due to increasing fractions of litter species with a higher litter quality in the mixture or in the surroundings of the incubated litterbags. We expected that the higher decomposition rates of litter mixtures can sufficiently be explained by additive effects on the basis of the quality of the individual litter species rather than by mixture-specific, non-additive effects.

\subsection{Materials and methods \\ Study site}

The study was conducted in semi-natural, old-growth forest stands (85 to 148-year-old in 2006; Schmidt et al. 2009) in the Hainich National Park, Thuringia, Central Germany. All research stands are situated at an elevation of about $350 \mathrm{~m}$ a.s.I. near the village of Weberstedt $\left(51^{\circ} 06^{\prime} \mathrm{N}, 10^{\circ} 31^{\prime} \mathrm{E}\right)$. At the Weberstedt meteorological station, the mean annual temperature is $7.5^{\circ} \mathrm{C}$, and the mean annual precipitation, $670 \mathrm{~mm}$. The soils are Luvisols with stagnic properties, developed from Pleistocene loess and are underlain by limestone (Triassic Upper Muschelkalk formation) (FAO 2006). They are characterized by high silt contents (approximately 75\%), and have a loess cover of at least $60 \mathrm{~cm}$ (Guckland et al. 2009). For the past four decades, the studied stands have developed a near-natural structure (cf. Mölder et al. 2008; Leuschner et al. 2009). Details of the stand structure are given in Table 1.

In April 2005, three stand types differing in their diversity levels (DL) of tree taxa were selected in the north-eastern part of the national park: (i) a stand type with European beech 
(Fagus sylvatica L.) as the predominating tree species (DL 1); (ii) a stand type mainly consisting of beech, lime (Tilia cordata Mill. and T. platyphyllos Scop.) and ash (Fraxinus excelsior L.) (DL 2); and (iii) a stand type with beech, lime, ash, hornbeam (Carpinus betulus L.) and maple (Acer pseudoplatanus L. and A. platanoides L.) as the dominant tree taxa (DL 3). At each diversity level (stand type), three plots of $50 \mathrm{~m} \times 50 \mathrm{~m}$ size each were selected, and fenced to exclude wild boars and other game. All plots were located within a radius of about $4 \mathrm{~km}$, and were comparable with respect to slope, physical soil conditions and climate. From the beginning of September, leaf litter was continuously sampled with litter collectors (aperture: $0.29 \mathrm{~m}^{2}$ ) that were arranged at a minimum distance of $2 \mathrm{~m}$ along three randomly positioned 30-m-long transects per plot (five collectors per transect). The bulk of the leaf litter fell from the beginning of October until mid-November. The collectors were emptied every two to three weeks from the beginning of September to the end of December 2005-2007. At all study plots, the air temperature was continuously recorded with temperature sensors $5 \mathrm{~cm}$ above the ground (HOBO RH/Temp H08-32-08; Onset Computer Corporation, Bourne, USA).

\section{Litterbag experiment}

At the beginning of November $2005,8 \mathrm{~g}$ of oven-dried $\left(25^{\circ} \mathrm{C}\right.$ for $48 \mathrm{~h}$ ) litter that had been collected in 2005 between the beginning of September until 31 October was filled into nylon bags with a surface area of $20 \mathrm{~cm}^{2}$ and a mesh size of $5 \mathrm{~mm}$. Two types of bags were prepared in this manner: (i) bags that contained litter in a mixture that was representative of the litter composition of the respective plot (MIX bags), and (ii) bags that contained litter of only one out of the five investigated tree species (Acer platanoides, Carpinus betulus, Fagus sylvatica, Fraxinus excelsior, Tilia cordata; i.e. MONO bags). The MONO-bag litter was derived from a random species-specific mixture from the plots of all DL levels, at which the respective tree species occurred. In part of the remaining litter, the initial concentrations of lignin and calcium ( $\mathrm{Ca}$ ) as well as the initial ratios of carbon to nitrogen ( $\mathrm{C}: \mathrm{N}$ ratios) and carbon to phosphorus (C:P ratios) were determined (see below). On 17 November 2005, the litterbags were placed into the upper stratum of the organic surface layer. To cover 6 sampling dates, $6 \mathrm{MIX}$ bags were incubated in each plot of all diversity levels (18 bags per DL, 6 sampling dates; 324 bags in total). In the case of the MONO bags, three bags per tree species and plot were placed in one plot at each per diversity level for being resampled on 3 dates ( 3 bags per DL, 5 species, 3 sampling dates; 135 bags in total). For the determination of mass loss on the basis of remaining litter, litterbags were removed on the following dates: 15 December 2005, 27 March 2006, 19 June 2006, 26 September 2006, 24 April 2007, and 18 September 2007. On these dates (except for sampling dates in 2007, when a large part of 
the litter mass had already decomposed), the lignin concentrations of the remaining material were analysed.

Table 1: Features of the investigated temperate deciduous forest stands differing in the diversity level $(\mathrm{DL})$ of tree species. Data are given as means \pm 1 SE $(n=3)$. Different letters indicate significant differences among DL (data compiled from Guckland et al. 2009 and Jacob et al., 2009)

\begin{tabular}{|c|c|c|c|}
\hline & DL 1 & DL 2 & DL 3 \\
\hline Fagus sylvatica (\% of canopy cover) & $96.1 \pm 1.9 \mathbf{a}$ & $67.1 \pm 3.5 \mathbf{b}$ & $21.4 \pm 13.0 \mathrm{c}$ \\
\hline Tilia spp. (\% of canopy cover) & $0.8 \pm 0.8 \mathbf{b}$ & $13.1 \pm 5.3 \mathrm{ab}$ & $40.3 \pm 11.0 \mathbf{a}$ \\
\hline Fraxinus excelsior (\% of canopy cover) & $0.5 \pm 0.5 \mathbf{a}$ & $14.2 \pm 3.9 \mathbf{a}$ & $10.7 \pm 4.3 \mathbf{a}$ \\
\hline Acer spp. (\% of canopy cover) & $0.9 \pm 0.4 \mathbf{b}$ & $4.5 \pm 1.0 \mathrm{~b}$ & $8.5 \pm 1.3 \mathbf{a}$ \\
\hline Carpinus betulus (\% of canopy cover) & $0.0 \pm 0.0 \mathbf{b}$ & $0.0 \pm 0.0 \mathbf{b}$ & $14.7 \pm 5.2 \mathbf{a}$ \\
\hline Humus type ${ }^{a)}$ & F-Mull & L-Mull & L-Mull \\
\hline $\begin{array}{l}\text { Thickness of organic surface layer, } \\
\text { annual average }(\mathrm{cm})^{\mathrm{b})}\end{array}$ & $2.8 \pm 0.1 \mathbf{a}$ & $2.4 \pm 0.1 \mathrm{~b}$ & $1.9 \pm 0.1 \mathrm{c}$ \\
\hline \multicolumn{4}{|l|}{ Soil water content in $0-10 \mathrm{~cm}$ of soil depth ${ }^{\mathrm{c})}$} \\
\hline winter 2005/2006 (Oct - Mar), range (vol.-\%) & $21.0-32.3$ & $19.1-35.4$ & $20.3-34.9$ \\
\hline summer 2006 (Apr - Sep), range (vol.-\%) & $15.5-34.2$ & $13.9-38.1$ & $13.7-37.4$ \\
\hline
\end{tabular}

\section{Chemical analyses}

In freshly fallen leaf litter and in part of the litter used for the litterbag experiment, the concentrations of lignin as well as the initial $\mathrm{Ca}$ concentration and the initial $\mathrm{C}: \mathrm{N}$ and $\mathrm{C}: \mathrm{P}$ ratios were measured. The bulk of the samples was analysed for lignin concentration using near-infrared spectroscopy (NIRS) as a rapid and accurate method for determining lignin in a large number of samples (e.g., Ono et al. 2008). To calibrate the NIRS method, the more time-consuming acetylbromide method was applied to approximately 100 samples, which had been collected at all diversity levels at all four measurement dates (November 2005 to June 2006). In about $400 \mathrm{mg}$ of dried $\left(60^{\circ} \mathrm{C}\right)$ and pulverized material per sample, lignin was chemically decomposed into soluble degradation products, whose concentrations were measured photometrically at $280 \mathrm{~nm}$ (Brinkmann et al. 2002). The measurements were calibrated using coniferyl alcohol (1 nmol coniferyl alcohol equals $180 \mathrm{mg}$ lignin). 
For the lignin determination by NIRS, dried and pulverised litter material was homogeneously filled into quartz cuvettes with a diameter of $2 \mathrm{~cm}$. In each sample, the reflectance was measured twice at wavelengths between 400 and $2500 \mathrm{~nm}$ at 2-nm increments using an NIR spectrometer (Foss NIRSystems 6500, Silver Spring, MD, USA). To minimise the effects of light scattering, the spectra were mathematically transformed to the second derivative (Brinkmann et al. 2002; Mclellan et al. 1991). Calibration was performed using the built-in WinISI software (WinISI II-software systems, Foss, Silver Spring, MD, USA) (for technical details see Tilmann 1996 and Brinkmann et al. 2002). In the samples measured by both methods, the lignin concentrations determined through the acetylbromide method and by NIRS correlated at an $R^{2}$ of 0.969 .

The $\mathrm{C}$ and $\mathrm{N}$ concentrations of the leaf litter were measured using an automated $\mathrm{C}: \mathrm{N}$ analyser (Heraeus Elementar Vario EL, Hanau, Germany). The concentrations of Ca and P were determined by ICP-AES (Spectro, Kleve, Germany) after pressure digestion with concentrated nitric acid.

\section{Data evaluation}

Decomposition rates $k$ (litter or lignin mass decomposed per $g$ initial litter mass and per day) were calculated using linear regressions from the mass losses during the first seven months of decomposition (November 2005 through June 2006; four dates of measurement). As the mass loss during this time period was approximately linear (cf. Fig. 1), we used linear regressions instead of the negative exponential decay that is often used in similar studies (Olson 1963, Bärlocher 2007). Means \pm 1 standard error are given in the presentation of the results. Differences among the diversity levels within a given tree species, and among the tree species within a given diversity level, were tested using the Kruskal Wallis test, followed by multiple pairwise Mann-Whitney Rank Sum tests ( $U$ tests) in the case of significance. Differences among the time courses of litter or lignin decomposition at the three diversity levels were tested using the Friedman test, followed by multiple pairwise comparisons using the Student-Newman-Keuls test in the case of significance. For the decomposition rates in the MONO bags, ANOVA was used for comparing the individual tree species (average values for all $\mathrm{DL}$ ) or DL (average values for all tree species), followed by post-hoc LSD in the case of significant differences. For each tree species, we tested the differences between predicted (on the basis of MONO litterbags) and measured percentages (in MIX litterbags) of the foliar litter mass remaining after seven months of incubation using the $t$ test for paired differences after having tested the differences on deviation from the normal distribution using the Kolmogorov-Smirnov test. Interrelationships between the initial $\mathrm{Ca}, \mathrm{N}$ and lignin concentrations in the litter as well as the initial $\mathrm{C}: \mathrm{N}, \mathrm{C}: \mathrm{P}$ and lignin: $\mathrm{N}$ ratios as the predictor 
variables, and the litter decomposition rate (November 2005 through June 2006) as the response variable, were tested by multiple regression. For the respective variables, we used values that had been averaged for the individual tree species at each DL $(n=12)$. The tests were performed using SPSS version 13.0.1 (SPSS Inc., Chicago, IL, USA). The significance level was $P<0.05$ in all cases.

\subsection{Results}

\section{Litter quality}

At all diversity levels (DL), the litter of Fagus sylvatica displayed the highest $\mathrm{C}: \mathrm{N}$ ratios (on average, $53 \mathrm{~g} \mathrm{~g} \mathrm{~g}^{-1}$; significant differences at DL 2 and, in the case of C:N ratios, also at DL 3) as well as the highest lignin concentrations (averaged over all DL, $85 \mathrm{mg} \mathrm{g}_{\mathrm{DM}}{ }^{-1}$ ) (Table 2). At DL 2 and DL 3, Fraxinus excelsior exhibited the lowest C:N ratios (on average of all DL, $31 \mathrm{~g} \mathrm{~g}^{-1}$ ). The $\mathrm{Ca}$ concentrations were highest in Tilia cordata (on average of all DL, $25.3 \mathrm{mg} \mathrm{g}_{\mathrm{DM}}{ }^{-1}$ ), and lowest, in Fagus (on average, $15.6 \mathrm{mg} \mathrm{g}_{\mathrm{DM}}{ }^{-1}$ ). Within a given tree species, the differences among DL were not significant.

\section{Decomposition of bulk litter}

Related to their initial values, the quantities of total dry mass and of lignin in the MIX litterbags were significantly higher at DL 1 than at DL 2 and DL 3 on the dates of resampling (Fig. 1). During the initial seven months of the experiment, the rates of litter and lignin decomposition were lowest at $\mathrm{DL} 1$, and highest, at DL 3 (Fig. 2). At given dates and time periods, the air temperatures (measured $5 \mathrm{~cm}$ above ground), which can influence the decomposition rates, were similar at all study plots (data not shown).

\section{Decomposition of litter from individual tree species}

With regard to the individual tree species (MONO bags), the masses of litter and lignin remaining after the initial seven months of the experiment (November 2005 to June 2006) were highest in Fagus (> 80\% and 76\%, respectively) and lowest in Fraxinus (less than 20\% of the initial litter and lignin) when averaged for all diversity levels (Fig. 3). The decomposition rates $(k)$ of litter and lignin from the individual tree species (MONO bags, mean values for a given DL) did not differ among DL (Fig. 4a, c). This result is in contrast to the significant differences in the $k$ values of the litter mixtures among DL (Fig. 2). Among the individual tree species, $k$ values of litter and lignin (averaged over all DL) did differ significantly: the highest values were found in Fraxinus, and the lowest, in Fagus (Fig. 4b, d). An additional KruskalWallis test performed separately for tree species and DL revealed that Fagus sylvatica was the only species whose litter (but not lignin) decomposition rates differed among DL: the $k$ 
value of Fagus litter was significantly higher at $\mathrm{DL} 1\left(0.70 \pm 0.02 \mathrm{mg} \mathrm{g}_{\mathrm{DM}}{ }^{-1} \mathrm{~d}^{-1}\right)$ than at $\mathrm{DL} 2$ and DL $3\left(0.56 \pm 0.07\right.$ and $\left.0.42 \pm 0.01 \mathrm{mg} \mathrm{g}_{\mathrm{DM}}{ }^{-1} \mathrm{~d}^{-1}\right)$.
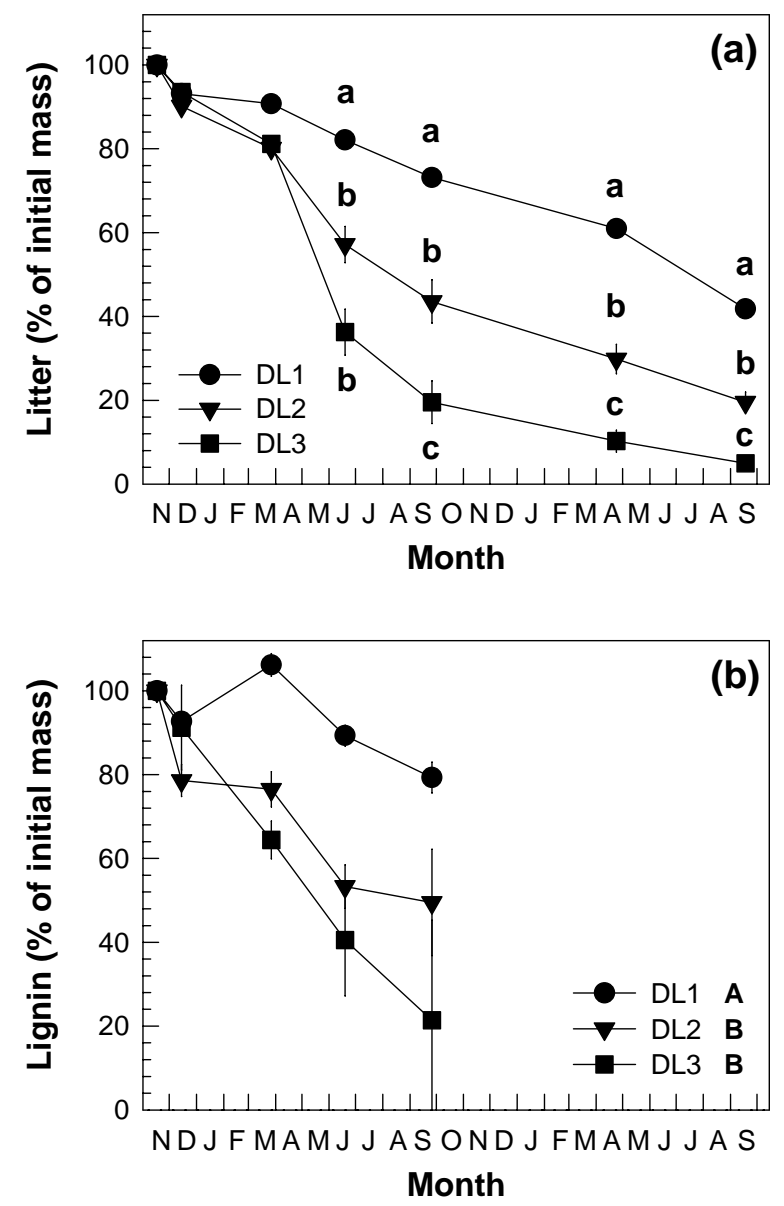

Fig. 1 Decomposition of (a) foliar litter and (b) foliar lignin in percent of their initial mass in the MIX litterbags exposed in temperate deciduous forest stands differing in tree species diversity (DL 1 DL 3) from November 2005 until (a) September 2007 (entire incubation period, 22 months) or (b) September 2006 (initial seven months of the incubation) (means \pm 1 SE). Different capital letters next to the symbol legends indicate significant differences among DL for the entire time course (Friedman test, followed by multiple pairwise comparisons using the Student-Newman-Keuls test; $P<0.05$ ). Different lower-case letters indicate significant differences among DL on a given date (Kruskal Wallis test, followed by multiple pairwise $U$ tests; $P<0.05$ ) (The latter test was not performed on the lignin values due to a lack of repetitive analyses on some dates). 

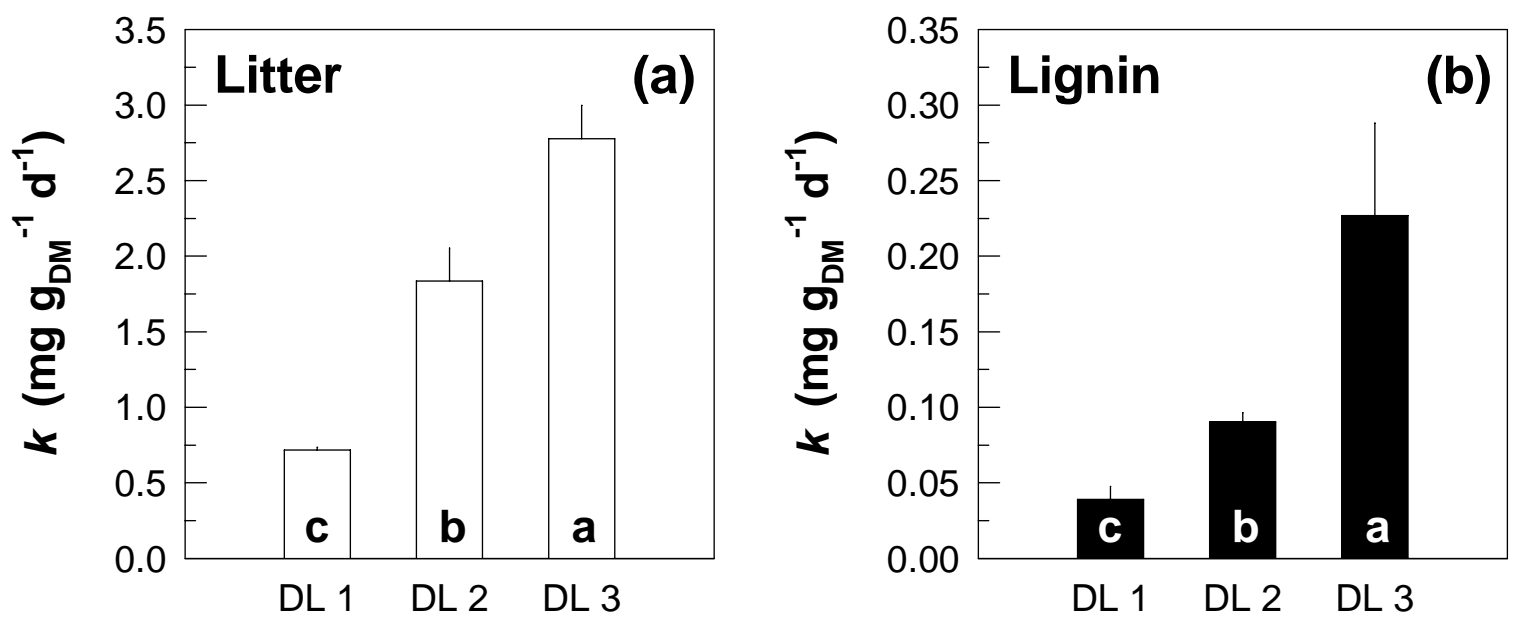

Fig. 2 Decomposition rates ( $k$; related to the initial litter mass) of (a) litter and (b) lignin in MIX litterbags incubated in temperate deciduous forest stands differing in their level of tree species diversity (DL 1 - DL 3). The rates were calculated for November 2005 - June 2006 (means \pm 1 SE). Different lower-case letters indicate significant differences among DL (Kruskal Wallis test, followed by multiple pairwise $U$ tests; $P<0.05$ )

To assess the mixture effect on the decomposition, we compared the percentage of the individual tree species' litter remaining in the MIX bags with the percentage predicted on the basis of the MONO bag data after seven months of decay in accordance with Hättenschwiler \& Gasser (2005) (Fig. 5). In Acer and Fagus, the predicted percentage of remaining litter mass on the basis of the MONO bags was tendentially higher than that measured in the mixture, which indicates a higher rate of decomposition in the mixture, whereas the opposite was true for Tilia. However, the differences between the measured and the predicted percentages were not significant in any of the species.

\section{Relationships between litter quality and decomposition rates}

The decomposition rates of the litter were significantly correlated with the initial $\mathrm{N}$ and $\mathrm{Ca}$ concentrations in the litter as well as with the initial $\mathrm{C}: \mathrm{N}, \mathrm{C}: \mathrm{P}$ and lignin:N ratios (Fig. 6). The initial lignin concentration was not significantly related to the decomposition rate. Multiple regression yielded its highest adjusted coefficient of determination $\left(R_{\mathrm{adj}}{ }^{2}\right)$ with the $\mathrm{N}$ concentration, the $C: P$ ratio and the $C: N$ ratio as predictor variables. However, with these predictor variables, the explanatory power was only slightly higher than that of a simple regression with $\mathrm{C}: \mathrm{N}$ as the sole predictor variable (Table 3). Inclusion of further variables resulted in lower $R_{\mathrm{adj}}{ }^{2}$ values, probably because of variance inflation due to multicollinearity among the variables. 
Table 2 Concentrations of calcium (Ca) and lignin, and ratios of carbon to nitrogen (C:N) and of carbon to phosphorus $(C: P)$ in tree litter freshly fallen in autumn in forest stands differing in the level of tree species diversity (DL) (mean values of 3 replicate plots $\pm 1 \mathrm{SE}$ ). Different lower-case letters indicate significant differences among tree species within a given DL (Kruskal Wallis test, $P<0.05$ ). Differences among DL within a given tree species were not significant.

\begin{tabular}{|c|c|c|c|}
\hline Tree species & DL 1 & DL 2 & DL 3 \\
\hline \multicolumn{4}{|l|}{$\mathbf{C a}\left(\mathrm{mg} \mathrm{g}_{\mathrm{DM}}{ }^{-1}\right)$} \\
\hline Fagus sylvatica & $12.5 \pm 1.1$ & $17.8 \pm 0.4 \mathbf{b}$ & $16.5 \pm 2.9$ \\
\hline Tilia cordata & - & $25.5 \pm 0.4 \mathbf{a}$ & $25.1 \pm 1.1$ \\
\hline Fraxinus excelsior & - & $23.1 \pm 0.8$ a & $23.2 \pm 1.0$ \\
\hline Acer platanoides & - & - & $21.4 \pm 0.7$ \\
\hline Carpinus betulus & - & - & $21.8 \pm 1.3$ \\
\hline \multicolumn{4}{|l|}{ Lignin (mg $\left.\mathrm{g}_{\mathrm{DM}}{ }^{-1}\right)$} \\
\hline Fagus sylvatica & $80.6 \pm 4.1$ & $86.7 \pm 1.8$ a & $88.7 \pm 4.6$ \\
\hline Tilia cordata & - & $71.6 \pm 1.7 \quad b$ & $75.7 \pm 2.9$ \\
\hline Fraxinus excelsior & - & $75.8 \pm 1.9$ b & $80.2 \pm 2.4$ \\
\hline Acer platanoides & - & - & $75.8 \pm 1.0$ \\
\hline Carpinus betulus & - & - & $80.7 \pm 3.2$ \\
\hline \multicolumn{4}{|l|}{ C:N $\left(\mathrm{g} \mathrm{g}^{-1}\right)$} \\
\hline Fagus sylvatica & $50.0 \pm 2.3$ & $52.7 \pm 1.1$ a & $57.4 \pm 3.7 \mathbf{a}$ \\
\hline Tilia cordata & - & $35.9 \pm 0.5$ b & $37.0 \pm 1.4 \mathrm{c}$ \\
\hline Fraxinus excelsior & - & $30.1 \pm 1.6$ c & $32.0 \pm 1.1 \mathrm{~d}$ \\
\hline Acer platanoides & - & - & $46.3 \pm 2.3 b$ \\
\hline Carpinus betulus & - & - & $38.6 \pm 2.2 \mathrm{c}$ \\
\hline \multicolumn{4}{|l|}{ C:P $\left(g^{-1}\right)$} \\
\hline Fagus sylvatica & $543 \pm 47$ & $717 \pm 120$ & $856 \pm 139$ \\
\hline Tilia cordata & - & $446 \pm 34$ & $517 \pm 80$ \\
\hline Fraxinus excelsior & - & $495 \pm 42$ & $532 \pm 44$ \\
\hline Acer platanoides & - & - & $580 \pm 50$ \\
\hline Carpinus betulus & - & - & $508 \pm 48$ \\
\hline
\end{tabular}


Chapter 4
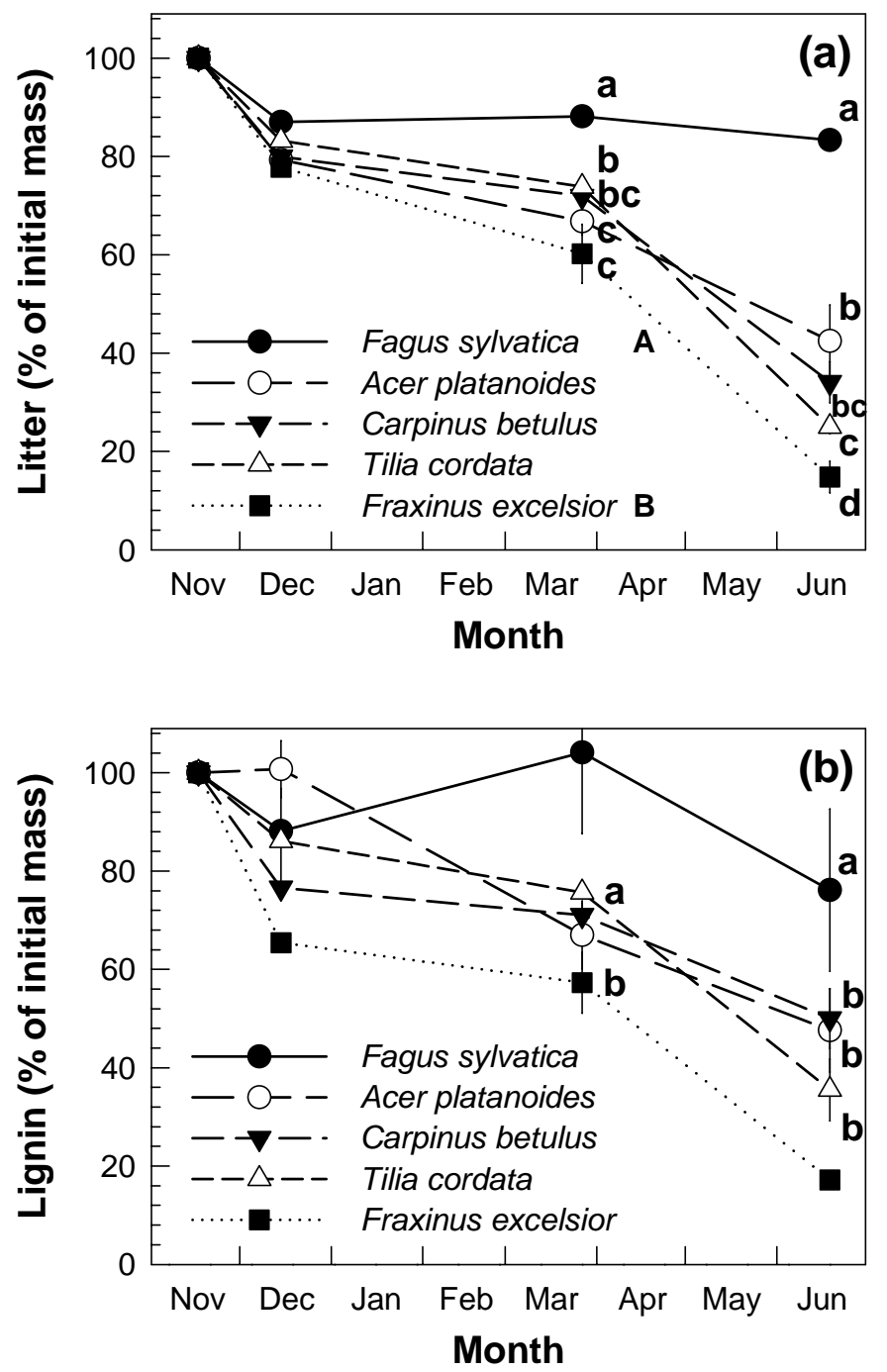

Fig. 3 Decomposition of (a) foliar litter and (b) foliar lignin in different temperate deciduous forest tree species in percent of their initial mass in MONO litterbags (average values of the three tree species diversity levels DL 1 -DL 3). The rates were calculated for November 2005 - June 2006 (means $\pm 1 \mathrm{SE}$ ). Different capital letters next to the symbol legends indicate significant differences among tree species for the entire time course (Friedman test, followed by multiple pairwise comparisons using the Student-Newman-Keuls test; $P<0.05)$. Different lower-case letters indicate significant differences among tree species on a given date (Kruskal Wallis test, followed by multiple pairwise $U$ tests; $P<0.05$ ). 
Table 3 Significant coefficients of determination $\left(R^{2}\right.$ and adjusted $\left.R^{2}\right)$ resulting from multiple regression analysis on the influence of the initial concentrations and ratios of several chemical compounds of the leaf litter from different deciduous forest tree species (Acer platanoides, Carpinus betulus, Fagus sylvatica, Fraxinus excelsior, Tilia cordata) on the decomposition rate (response variable) during the initial seven months of decomposition (November 2005 - June 2006). The analysis was performed on average values of the individual tree species (MONO litterbags) at the different diversity levels $(n=12)$.

\begin{tabular}{llll}
\hline Predictor variables & $\boldsymbol{R}^{2}$ & $\boldsymbol{R}_{\mathrm{adj}}{ }^{2}$ & $\boldsymbol{P}$ \\
\hline C:N & 0.867 & 0.853 & $<0.001$ \\
C:P, N & 0.900 & 0.877 & $<0.001$ \\
C:N, C:P, N & 0.911 & 0.878 & $<0.001$ \\
C:N, C:P, N, Ca & 0.922 & 0.877 & $<0.001$ \\
C:N, C:P, N, Ca, lignin:N & 0.927 & 0.867 & 0.002 \\
C:N, C:P, N, Ca, lignin:N, lignin & 0.929 & 0.844 & 0.010 \\
\hline
\end{tabular}
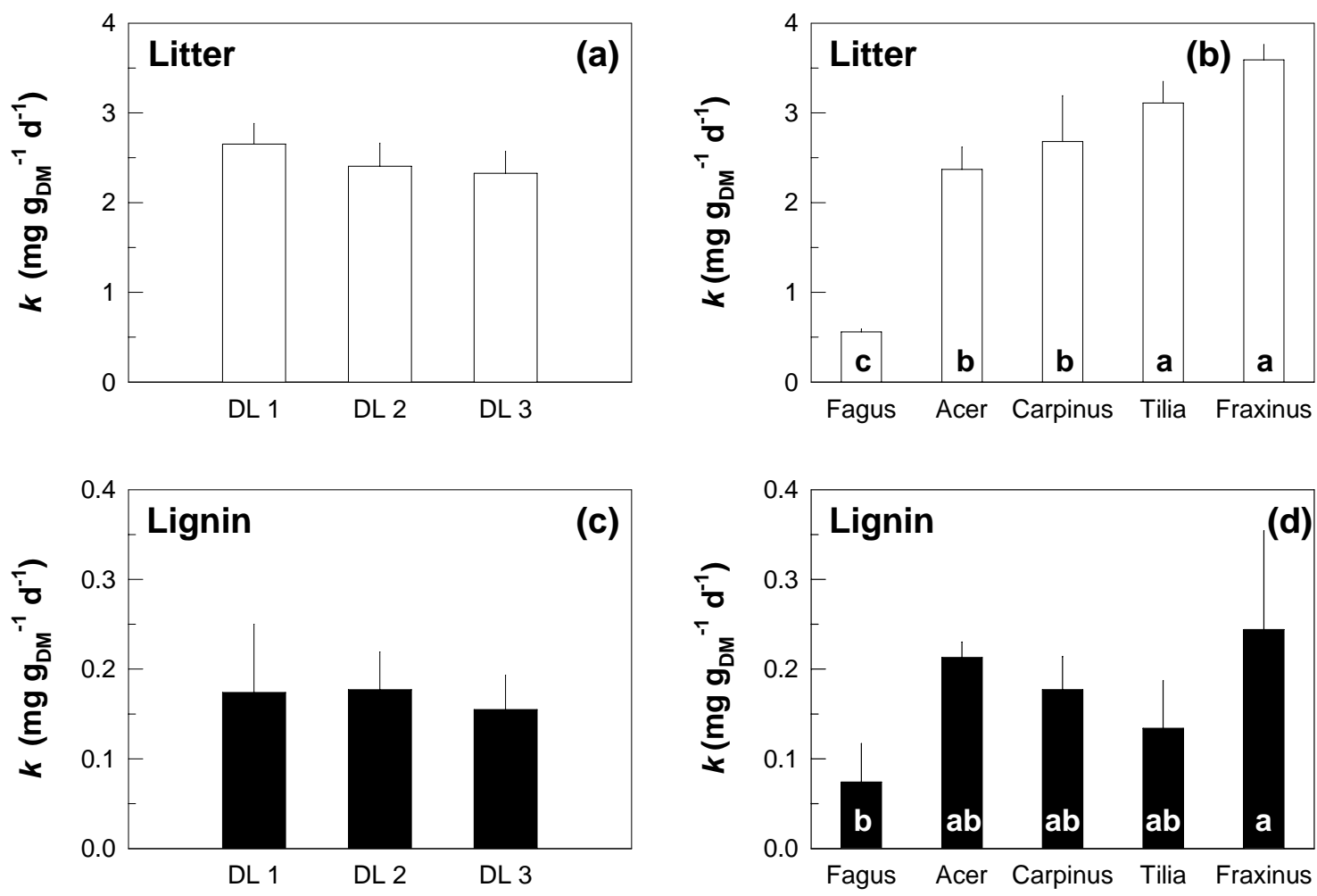

Fig. 4 Decomposition rates ( $k$; related to the initial litter mass) of litter $(\mathbf{a}, \mathbf{b})$ and lignin (c, d) in MONO litterbags incubated in temperate deciduous forest stands differing in their level of tree species diversity (DL 1 - DL 3). The rates were calculated for November 2005 - June 2006 (means \pm 1 SE). The means were averaged for a given $\mathrm{DL}$ from the litter of all tree species incubated there (Acer platanoides, Carpinus betulus, Fagus sylvatica, Fraxinus excelsior, Tilia cordata) (a, c), or over all DL (DL 1 - 3) for a given tree species (b, d). Different lower-case letters indicate significant differences among the tree species (ANOVA, followed by post-hoc LSD tests; $P<0.05$ ). Differences among DL were not significant. 


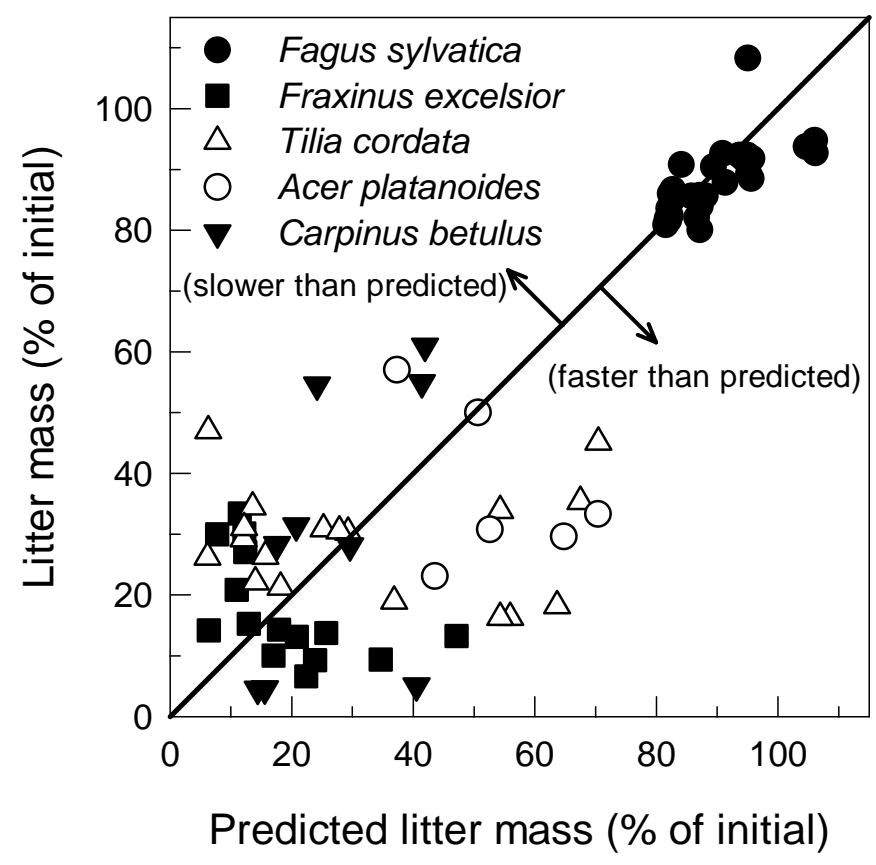

Fig. 5 Predicted (on the basis of MONO litterbags) and measured percentages (in MIX litterbags) of the different tree species foliar litter remaining after seven months of incubation in all DL (DL 1-3). The diagonal represents a 1:1 ratio. Within a given tree species, the differences between measured and predicted differences were not significant ( $t$ test for paired differences).

\subsection{Discussion}

The litter decomposition rates varied among the investigated tree species but, in most species, were neither influenced by litter mixing (i.e., by raising the litter diversity) nor by the degree of the tree species diversity at the sites of decomposition.

\section{Decomposition of litter from individual tree species}

A recent study by Kalbitz et al. (2006) on the dynamics of litter decomposition in temperate forests, including the Central-European deciduous tree species Acer pseudoplatanus and Fagus sylvatica, provided evidence of a two-phase kinetics of litter decay: a first, almost linear phase of mass loss in the initial 5-12 months, and a second, more or less saturated phase in the subsequent 15 months. Our results are in accordance with these observations and show an approximately linear course of litter degradation during the initial seven months (Fig. 1). This time course also fits the well-known general dynamics of litter decay, which exhibit a nearly linear course in the early stage of decomposition (Olson 1963; Berg 2000). Therefore, the approximation of a linear decomposition rate for the initial seven months of the experiment is justified. 

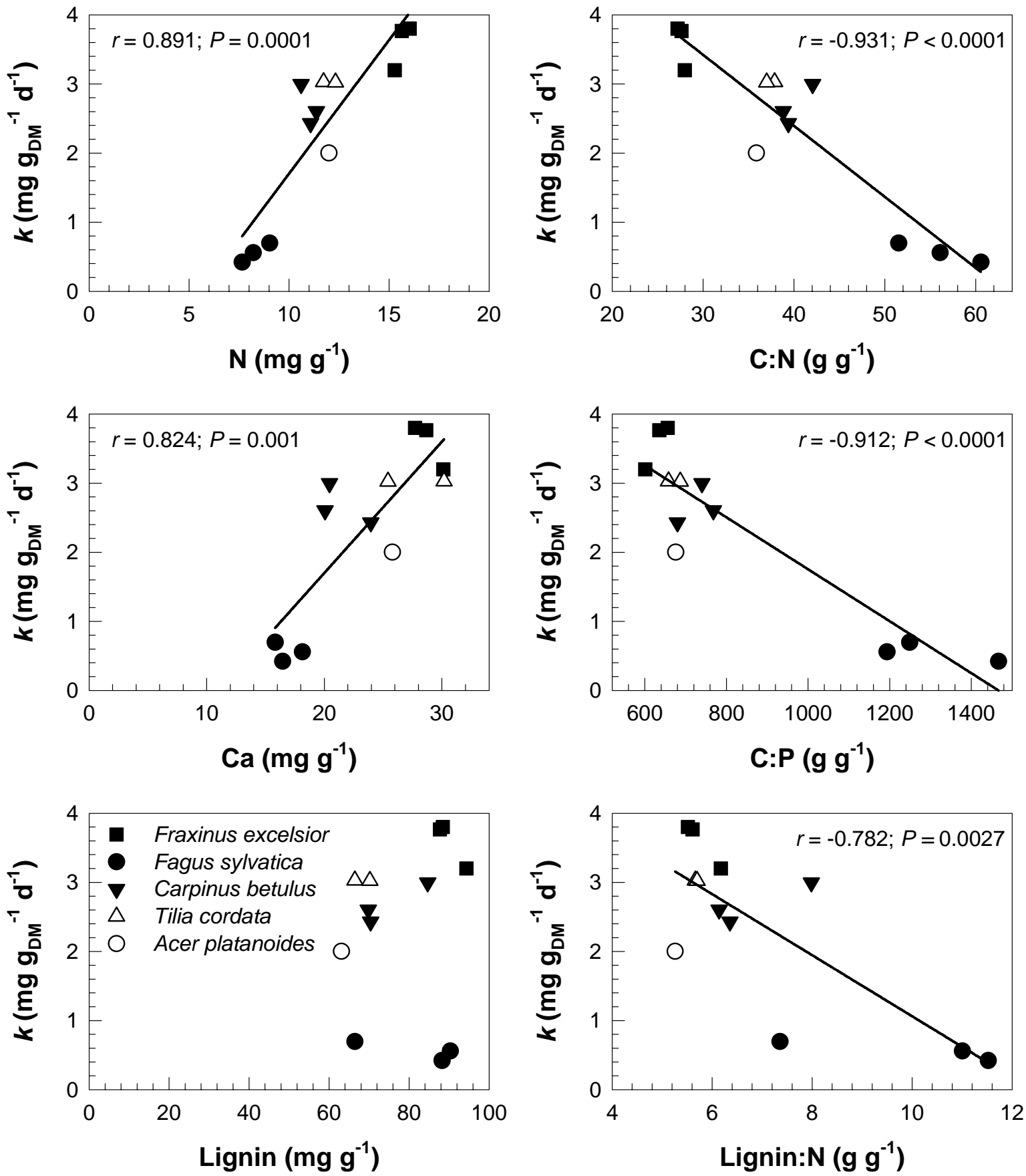

Fig. 6 Rates of litter decomposition ( $k$ ) plotted against the initial concentrations or ratios of nutrients or lignin in the litter from MONO litterbags incubated in temperate deciduous forest stands differing in the level of tree species diversity. Mean values of the diversity levels were used for each tree species. The decomposition rates were calculated for November 2005 - June 2006. In cases of significant $(P<0.05)$ Pearson correlation coefficients $(r), r$ and the respective levels of significance are given. 
Generally, the beech leaf litter exhibits only slow decomposition rates, which commonly is ascribed to its relatively high C: $\mathrm{N}$ ratio of approximately $40-60 \mathrm{~g} \mathrm{~g}^{-1}$ compared to the distinctly lower C:N ratios in the litter of ash, hornbeam and lime (e.g., Wise \& Schaefer 1994; Cotrufo et al. 2000; Hättenschwiler \& Gasser 2005; Ritter \& Bjørnlund 2005; Hobbie et al. 2006). In our study, the initial litter decomposition rates were significantly correlated with the initial $\mathrm{N}$ concentrations as well as with the initial $\mathrm{C}: \mathrm{N}$ and lignin: $\mathrm{N}$ ratios of the litter. Therefore, our results support the finding that the $\mathrm{N}$ concentrations, or the ratios of $\mathrm{N}$ to other foliar compounds, are among the principal factors affecting the rates of litter decomposition in a particular climatic region (Cornelissen 1996; Aerts 1997; Heal et al. 1997; Parton et al. 2007). The concentrations of macronutrients other than $\mathrm{N}$ in the litter can influence the decomposition. For example, in line with our study, the decomposition rates of litter from Central-European forest trees including Acer pseudoplatanus, Carpinus betulus, Fagus sylvatica and Tilia cordata were positively correlated with the Ca concentration of the litter in a common-garden experiment (Hobbie et al. 2006). However, in this context two aspects have to be considered: (i) that correlations between nutrient concentrations and litter decomposition rates do not necessarily imply that litter quality controls litter decay, and (ii) that simple extrapolations of decomposition rates from early stages of decay to long-term rates might yield erroneous results (Prescott 2005).

In contrast to other studies on temperate forest tree species (Osono \& Tadeka 2005; Hobbie et al. 2006; Madritch \& Cardinale 2007; Sariyildiz 2008), we found no significant correlation between decomposition rates and the lignin concentration of the litter. This was probably due to the relatively small range of lignin concentrations in the litter. Moreover, lignin's regulation of litter decomposition is generally not presumed to take effect before the onset of the second phase of degradation (Kalbitz et al. 2006; Berg \& McClaugherty 2008), which starts when the mass loss of litter exceeds a species-specific level. This level might not have been reached during the period for which the decomposition rates were calculated.

Due to the chemical composition of their leaves, forest trees create specific conditions that influence the decomposition of their own litter in the long-term (Reich et al. 2005; Sariyildiz \& Anderson 2005; Vivanco \& Austin 2008). Apart from affecting the chemical composition of the soil, litter that is only slowly degradable builds up thicker layers of organic matter on the soil surface, which persist over longer periods of time. The structure of the organic surface layer, in turn, can affect the rates of litter decomposition as a result of the microclimatic conditions (Sayer 2006; Sariyildiz 2008). In our study, the thicker organic surface layer in the stands dominated by Fagus sylvatica (DL 1) might have preserved a more favourable moisture regime during the decomposition process than at $\mathrm{DL} 2$ and $\mathrm{DL} 3$. At the latter $-86-$ 
diversity levels (especially at $D L 3$ ), the more rapid decomposition of the readily degradable Fraxinus and Tilia litter, which presumably is a more attractive resource to the decomposers due to its lower $\mathrm{C}: \mathrm{N}$ ratios, left behind a thinner litter layer. In late spring (seven months after the onset of decomposition), this layer consisted mainly of the more persistent Fagus litter, whose decomposition might have been further retarded by the lower moisture during the warm summer months. In the multispecific stands, this might have impeded the degradation of Fagus litter even more. The moisture regime in the litter layer and decomposer preferences might explain the finding that the decomposition rates of Fagus litter at DL 2 and DL 3 during the first seven months of decay were significantly lower than in the almost pure Fagus stands of DL 1 . However, when a longer time period (22 months) of decomposition is considered, the decomposition of Fagus litter was more rapid at DL 3 than at DL 1; (Jacob et al. 2009). On the basis of our results, we have to reject the hypothesis that, in its initial phase, Fagus litter decomposition is more rapid in the presence of more readily degradable leaf litter of other deciduous species.

\section{Decomposition across the diversity levels}

The large differences between the decomposition rates of beech litter and those of litter from the other investigated tree species also influenced the decomposition rates of the standspecific litter mixtures, which were highest at DL 3. In those stands with the highest tree diversity, tree species with low initial C:N ratios in their litter (Carpinus betulus, Fraxinus excelsior, Tilia cordata) together made up nearly two thirds of the canopy cover, whereas the species with the highest C:N ratio (Fagus sylvatica) contributed only about $21 \%$. The standspecific litter mixtures reflected the contribution of the tree species to the canopy cover. Despite distinct differences among DL in soil chemistry (Guckland et al. 2009), the nutrient concentrations and ratios of Fagus litter did not differ significantly among DL. Thus, high fractions of Fagus sylvatica in the litter mixtures were connected with lower decomposition rates of total litter and lignin. The decomposition of litter from individual tree species in litter mixtures did not differ significantly from that predicted on the basis of litter decomposed in isolation. These results are indicative of additive decomposition characteristics as opposed to non-additive ones (c.f. Gartner \& Cardon 2004). Hence, the differences among the decomposition rates of the litter mixtures from the various diversity levels were due to the specific traits of the individual tree species involved, and to their interrelations with the site factors rather than to the diversity of the litter mixtures per se. On a larger geographical scale, a similar result was found in a study investigating a transect from dry to mesic forests in Central North America including broad-leaved deciduous tree species (Madritch \& Cardinale 2007): the decomposition rates were strongly dependent on the presence or absence of few individual species, but not on leaf litter diversity itself. Generally, the 


\section{Chapter 4}

existence of species-specific traits of the trees in temperate forest ecosystems seems to make the effects of litter mixing on the decomposition rates nearly unpredictable (Hättenschwiler et al. 2005; De Deyn et al. 2008). This also seems to be true for tropical forest plantations (Scherer-Lorenzen et al. 2007), and for forest and non-forest ecosystems of chronosequences on a global scale (Wardle et al. 2009).

The annual leaf litter production of the investigated stands was 3.2-3.9 $\mathrm{Mg} \mathrm{ha}^{-1} \mathrm{yr}^{-1}$, with no significant differences among the levels of tree species diversity (Guckland et al. 2009). The higher decomposition rates in the stands with a higher tree species diversity is indicative of a faster release of nutrients and, thus, of a more rapid nutrient cycling. However, the basal area-related productivity of the beech is not higher in the mixed than in the pure ones (Jacob et al. in press). Hence, along the investigated gradient of tree species diversity, the productivity of the beech seems to be unaffected by current litter decomposition rates. This is consistent with the objection by Prescott (2005) that rates of litter decomposition may not be critical for productivity. In contrast, high rates of litter decomposition may be essential for sustaining the productivity of the stands with higher tree species diversity. These stands also harbour a more diverse herb layer (Mölder et al. 2008), which most probably influences the decomposition rates (e.g., Wise \& Schaefer 1994). Thus, the site conditions of the different stand types, in combination with the specific traits of the predominating tree species, might be more important for the rates of litter decomposition and nutrient release than tree species diversity itself.

\section{Acknowledgements}

We thank Nadine Weland (Dept. of Ecology, Johann Friedrich Blumenbach Institute of Zoology and Anthropology, Georg-August-Universität Göttingen) for providing data on the thickness of the organic surface layer; and Inga Krämer (Dept. of Tropical Silviculture and Forest Ecology, Burckhardt-Institute, Georg-August-Universität Göttingen) for providing data on the soil water content. The study was funded by the Deutsche Forschungsgemeinschaft (Graduiertenkolleg 1086). The experiments comply with the laws of Germany where they have been conducted. 


\subsection{References}

Ad-hoc-Arbeitsgruppe Boden (2005) Bodenkundliche Kartieranleitung. Schweizerbart'sche Verlagsbuchhandlung, Stuttgart

Aerts R (1997) Climate, leaf litter chemistry and leaf litter decomposition in terrestrial ecosystems: A triangular relationship. Oikos 79:439-449

Ball BA, Hunter MD, Kominoski JS, Swan CM, Bradford MA (2008) Consequences of nonrandom species loss for decomposition dynamics: experimental evidence for additive and non-additive effects. J Ecol 96:303-313

Balvanera P, Pfisterer AB, Buchmann N, He JS, Nakshizuka T, Raffaelli D, Schmid B (2006) Quantifying the evidence for biodiversity effects on ecosystem functioning and services. Ecol Letters 9:1146-1156

Bärlocher F (2007) Leaf mass loss estimated by litter bag technique. In: Graça MAS, Bärlocher F, Gessner MO (eds) Methods to Study Litter Decomposition - A Practical Guide. Springer, Dordrecht, pp 37-42

Berg B (2000) Litter decomposition and organic matter turnover in northern forest soils. For Ecol Manage 133:13-22

Berg B, McClaugherty C (2008) Plant Litter - Decomposition, Humus Formation, Carbon Sequestration, 2nd edn. Springer, Berlin

Boerjan W, Ralph J, Baucher M (2003) Lignin biosynthesis. Annu Rev Plant Biol 54:519-546

Brinkmann K, Blaschke L, Polle A (2002) Comparison of different methods for lignin determination as a basis for calibration of near-infrared reflectance spectroscopy and implications of lignoproteins. J Chem Ecol 28:2483-2501

Cornelissen JHC (1996) An experimental comparison of leaf decomposition rates in a wide range of temperate plant species and types. J Ecol 84:573-582

Cotrufo MF, Miller M, Zeller B (2000) Litter decomposition. In: Schulze E-D (ed) Carbon and Nitrogen Cycling in European Forest Ecosystems. Ecological Studies 142. Springer, Berlin etc., pp 276-296

De Deyn GB, Cornelissen JHC, Bardgett RD (2008) Plant functional traits and soil carbon sequestration in contrasting biomes. Ecol Letters 11:516-531

Ellenberg H (1996) Vegetation Mitteleuropas mit den Alpen, 5th edn. Ulmer, Stuttgart 
FAO (2006) FAO, ISRIC, ISSS World Reference Base for Soil Resources 2006. Report No. 103, World Soil Resources Reports, Rome

Gartner TB, Cardon ZG (2004) Decomposition dynamics in mixed-species leaf litter. Oikos 104:230-246

Guckland A, Jacob M, Flessa H, Thomas FM, Leuschner C (2009) Acidity, nutrient stocks, and organic-matter content in soils of a temperate deciduous forest with different abundance of European beech (Fagus sylvatica L.). J Plant Nutr Soil Sci 172:500-511

Hättenschwiler S, Gasser P (2005) Soil animals alter plant litter diversity effects on decomposition. PNAS 102:1519-1524

Hättenschwiler S, Tiunov AV, Scheu S (2005) Biodiversity and litter decomposition in terrestrial ecosystems. Annu Rev Ecol Evol Syst 36:191-218

Heal OW, Anderson JM, Swift MJ (1997) Plant litter quality and decomposition: An historical overview. In: Cadish G, Giller KE (eds) Driven by Nature: Plant litter quality and decomposition. CAB International, Wallingford, pp 3-30

Hobbie SE, Reich PB, Oleksyn J, Ogdahl M, Zytkowiak R, Hale C, Karolewski P (2006) Tree species effects on decomposition and forest floor dynamics in a common garden. Ecology 87:2288-2297

Hooper DU, Chapin III FS, Ewel JJ, Hector A, Inchausti P, Lavorel S, Lawton JH, Lodge DM, Loreau M, Naeem S, Schmid B, Setälä H, Symstad AJ, Vandermeer J, Wardle DA (2005) Effects of biodiversity on ecosystem functioning: A consensus of current knowledge. Ecol. Monogr 75:3-35

Jacob M, Weland N, Platner C, Schaefer M, Leuschner C, Thomas FM (2009) Nutrient release from decomposing leaf litter of temperate deciduous forest trees along a gradient of increasing tree species diversity. Soil Biol Biochem 41:2122-2130

Jacob M, Leuschner C, Thomas FM (2010). Productivity of temperate broad-leaved forest stands differing in tree species diversity. Ann For Sci (in press)

Kalbitz K, Kaiser K, Bargholz J, Dardenne P (2006) Lignin degradation controls the production of dissolved organic matter in decomposing foliar litter. Eur J Soil Sci57:504516 
Leuschner C, Jungkunst HF, Fleck S (2009) Functional role of forest diversity: pros and cons of synthetic stands and across-site comparisons in established forests. Basic Appl Ecol $10,1-9$

Madritch MD, Cardinale BJ (2007) Impacts of tree species diversity on litter decomposition in northern temperate forests of Wisconsin, USA: a multi-site experiment along a latitudinal gradient. Plant Soil 292:147-159

McLellan TM, Aber JD, Martin ME, Melillo JM, Nadelhoffer KJ (1991) Determination of nitrogen, lignin, and cellulose content of decomposing leaf material by near-infrared reflectance spectroscopy. Can J For Res 21:1684-1688

Meier CL, Bowman WD (2008) Links between plant litter chemistry, species diversity, and below-ground ecosystem function. PNAS 105:19780-19785

Melillo JM, Aber JD, Muratore JF (1982) Nitrogen and lignin control of hardwood leaf litter decomposition dynamics. Ecology 63:621-626

Mölder A, Bernhardt-Römermann M, Schmidt W (2008) Herb-layer diversity in deciduous forests: Raised by tree richness or beaten by beech? For Ecol Manage 256:272-281

Olson JS (1963) Energy storage and balance of producers and decomposers in ecological systems. Ecology 44:322-331

Ono K, Miki K, Amari M, Hirai K (2008) Near-infrared reflectance spectroscopy for the determination of lignin-derived compounds in the decomposed and humified litters of coniferous and deciduous temperate forests in Northern Kanto District, Central Japan. Soil Sci Plant Nutr 54:188-196

Osono T (2007) Ecology of ligninolytic fungi associated with leaf litter decomposition. Ecol Res 22:955-974

Osono T, Takeda H (2005) Decomposition of organic chemical components in relation to nitrogen dynamics in leaf litter of 14 tree species in a cool temperate forest. Ecol Res 20:41-49

Parton W, Silver WL, Burke IC, Grassens L, Harmon ME, Currie WS, King JY, Adair EC, Brandt LA, Hart SC, Fasth B (2007) Global-scale similarities in nitrogen release patterns during long-term decomposition. Science 315:361-364

Prescott CE (2005) Do rates of litter decomposition tell us anything we really need to know? For Ecol Manage 220:66-74 
Reich PB, Oleksyn J, Modrzynski J, Mrozinski P, Hobbie SE, Eissenstat DM, Chorover J, Chadwick OA, Hale CM, Tjoelker MG (2005) Linking litter calcium, earthworms and soil properties: a common garden test with 14 tree species. Ecol Letters 8:811-818

Ritter E, Bjørnlund L (2005) Nitrogen availability and nematode populations in soil and litter after gap formation in a semi-natural beech-dominated forest. Appl Soil Ecol 28:175-189

Sariyildiz T (2008) Effects of gap-size classes on long-term litter decomposition rates of beech, oak and chestnut species at high elevations in Northeast Turkey. Ecosystems 11:841-853

Sariyildiz T, Anderson JM (2005) Variation in the chemical composition of green leaves and leaf litters from three deciduous tree species growing on different soil types. For Ecol Manage 210:303-319

Sayer EJ (2006) Using experimental manipulation to assess the roles of leaf litter in the functioning of forest ecosystems. Biol Rev 81:1-31

Scherer-Lorenzen M, Bonilla JL, Potvin C (2007) Tree species richness affects litter production and decomposition rates in a tropical biodiversity experiment. Oikos 116:21082124

Scherer-Lorenzen M, Körner C, Schulze E-D (2005) The functional significance of forest diversity: a synthesis. In: Forest Diversity and Function. Ecological Studies 176. Springer, Berlin Heidelberg New York, pp 377-389

Schmidt I, Leuschner C, Mölder A, Schmidt W (2009) Structure and composition of the seed bank in monospecific and tree species-rich temperate broad-leaved forests. For Ecol Manage 257: 695-702

Schulze E-D (2000) The carbon and nitrogen cycle of forest ecosystems. In: Schulze E-D (ed) Carbon and Nitrogen Cycling in European Forest Ecosystems. Ecological Studies 142. Springer, Berlin etc., pp 3-13

Spehn EM, Hector A, Joshi J, Scherer-Lorenzen M, Schmid B, Bazeley-White E, Beierkuhnlein C, Caldeira MC, Diemer M, Dimitrakopoulos PG, Finn JA, Freitas J, Giller PS, Good J, Harris R, Hogberg P, Huss-Danell K, Jumpponen A, Koricheva J, Leadley PW, Loreau M, Minns A, Mulder CPH, O’Donovan G, Otway SJ, Palmborg C, Pereira JS, Pfisterer AB, Prinz A, Read DJ, Schulze E-D, Siamantziouras ASD, Terry AC, Troumbis AY, Woodward FI, Yachi S, Lawton JH, (2005) Ecosystem effects of biodiversity manipulations in European grasslands. Ecol Monogr 75:37-63 
Tillmann P (1996) Kalibrationsentwicklung für NIRS-Geräte - eine Einführung. CuvillierVerlag, Göttingen

Vivanco L, Austin AT (2008) Tree species identity alters forest litter decomposition through long-term plant and soil interactions in Patagonia, Argentina. J Ecol 96:727-736

Wardle DA, Bardgett RD, Walker LR, Bonner KI (2009) Among- and within-species variation in plant litter decomposition in contrasting long-term chronosequences. Funct Ecol 23:442-453

Wardle DA, Bonner KI, Nicholson KS (1997) Biodiversity and plant litter: experimental evidence which does not support the view that enhanced species richness improves ecosystem function. Oikos 79:247-258

Wise DH, Schaefer M (1994) Decomposition of leaf litter in a mull beech forest: comparison between canopy and herbaceous species. Pedobiologia 38:269-288 
- 94 - 


\section{Chapter}

5

Nutrient release from decomposing leaf litter of temperate deciduous forest trees along a gradient of increasing tree species diversity

Mascha Jacob, Nadine Weland, Christian Platner, Matthias Schaefer, Christoph Leuschner, Frank M Thomas

(Published in: Soil Biology and Biochemistry 41:2122-2130) 


\title{
Nutrient release from decomposing leaf litter of temperate deciduous forest trees along a gradient of increasing tree species diversity
}

\author{
Mascha Jacob ${ }^{\mathrm{a}}$, Nadine Weland ${ }^{\mathrm{b}, *}$, Christian Platner $^{\mathrm{b}}$, Matthias Schaefer ${ }^{\mathrm{b}}$, \\ Christoph Leuschner ${ }^{\mathrm{a}}$, Frank M. Thomas ${ }^{\mathrm{c}}$ \\ ${ }^{a}$ Plant Ecology, Albrecht von Haller Institute for Plant Sciences, Georg-August-Universität Göttingen, Untere Karspüle 2, 37073 Göttingen, Germany \\ ${ }^{\mathrm{b}}$ Ecology Group, Johann-Friedrich-Blumenbach-Institute of Zoology and Anthropology, Georg-August-Universität Göttingen, Berliner Str. 28, 37073 Göttingen, Germany \\ ' Geobotany, Faculty of Geography and Geosciences, University of Trier, Behringstr. 21, 54296 Trier, Germany
}

\section{A R T I C L E I N F O}

Article history:

Received 21 January 2009

Received in revised form

20 July 2009

Accepted 25 July 2009

Available online 4 August 2009

\section{Keywords:}

Decomposition rate

Litter decay

Soil fauna

Nutrient release

Tree species diversity

Litterbag

Litterbag

(n)

\begin{abstract}
A B S T R A C T
In the litter of six deciduous tree species (Fagus sylvatica, Tilia spp., Fraxinus excelsior, Carpinus betulus, Acer pseudoplatanus and Acer platanoides) and in stand-specific litter mixtures, we compared mass loss and nutrient release across diversity levels along a gradient of decreasing proportion of Fagus in stands with similar environmental and physical soil conditions. The litterbag studies ran over 22 months. The decomposition rate constants $(k)$ of the temperate forest species ranged from $k=0.5$ for Fagus to $k=1.5-2$ for all other tree species. In Fagus, $k$ was closely negatively correlated with the thickness of the litter layer and positively correlated with soil $\mathrm{pH}$ and isopod abundance. $k$ was significantly higher in the mixed species stands (except for Carpinus and Fraxinus) and was positively correlated with earthworm abund ance. Over the whole incubation time, nutrient amount and release rates of $\mathrm{N}, \mathrm{P}, \mathrm{K}, \mathrm{Ca}$ and $\mathrm{Mg}$ as well as C-related ratios showed significant differences between tree species but no consistent differences among the diversity levels. Initial C-related nutrient ratios of the leaf litter and abundance of mesofauna and macrofauna were correlated with the length of time lag before nutrient release. We conclude that the mere number of tree species is not the main driver of nutrient release and decomposition processes, but that key groups of the decomposer fauna as well as the characteristic traits of the individual tree species are decisive.
\end{abstract}

(c) 2009 Elsevier Ltd. All rights reserved.

\section{Introduction}

There is a vital debate about the effects of plant species diversity on ecosystem functions such as productivity, nutrient cycling and carbon storage in managed and near-natural ecosystems (e.g., Hooper et al., 2005; Hector et al., 2007). Effects of biodiversity on ecosystem functioning were mainly studied with grassland experiments. Such experiments with artificially created gradients of even-aged plants are important to detect underlying mechanisms between diversity and ecosystem processes, although they have shortcomings to transfer these results to multi-aged mature forest stands with complex stand structure and a high longevity of dominant trees (Scherer-Lorenzen et al., 2007). Therefore, observational studies in mixed forests comparing adult trees of stands with nearnatural structure, intact food web structures and nutrient cycling at a quasi steady state are indispensable (Leuschner et al., 2009). Our study aimed at investigating the effects of tree species diversity in

\footnotetext{
* Corresponding author. Tel.: +49 55139 5559; fax: +49 551395448. E-mail address: nfahren@gwdg.de (N. Weland).
}

terms of species richness on the decomposition of and the nutrient release from litter of tree leaves, which are two fundamental processes that underlie the supporting services of ecosystems. The study was performed in near-natural forest stands with beech as the main tree species as this is the predominant tree species in Central Europe.

Plant litter decomposition has long been recognized as an essential process for organic matter turnover and nutrient fluxes in most ecosystems. The subsequent release of carbon (C) and nutrients represents the primary source of nutrients for plants and microbes (e.g., Swift et al., 1979; Berg and McClaugherty, 2008). These are key processes for the functioning of ecosystems and the delivery of ecosystem goods and services (Hättenschwiler and Gasser, 2005). Rates of plant litter decomposition and nutrient mineralization are influenced mainly by three factors: (i) climate on a broad regional scale with warmer and more humid climate generally leading to faster decomposition, (ii) litter quality on a smaller scale with higher nitrogen $(\mathrm{N})$ contents mostly enhancing decomposition and (iii) nature and abundance of decomposing organisms (Côteaux et al., 1995; Jonsson and Wardle, 2008). Plant species composition affects ecosystem nutrient cycling through plant-nutrient uptake and use, 
amount and chemical composition of the leaf litter, rhizosphere interactions and microenvironmental changes (Hättenschwiler et al., 2005; Hättenschwiler and Gasser, 2005).

There is increasing interest in the interactions among litter types and their effects on decomposer-driven processes such as litter decomposition and nutrient mineralization (e.g. Blair et al., 1990; McTiernan et al., 1997; Wardle et al., 1997; reviewed by Gartner and Cardon, 2004). In recent years, studies have revealed that the rates of mixed-litter mass loss may deviate greatly from those expected from the correspondent single-species litter decomposition rates. This was ascribed to non-additive effects of mixtures on mass loss, nutrient dynamics and decomposer associations compared to lea litter of an individual species, resulting in enhanced decomposition in the mixture (e.g., Gartner and Cardon, 2004; Brandtberg and Lundkvist, 2004; Gnankambary et al., 2008; Harguindeguy et al. 2008). Studies using litterbag experiments on single- and mixedspecies litter decomposition rates often neglected the influence of the decomposer fauna (mesofauna and especially macrofauna), although the interaction of the leaf litter composition with the soil fauna has been shown to alter the decomposition rates of the litter as has been revealed by a number of studies (e.g. Seastedt, 1984; Schädler and Brandl, 2005; Hättenschwiler and Gasser, 2005). The relationship between litter-species richness and decomposition rates or nutrient dynamics is thus difficult to predict with the identity and the functional traits of the species within a mixture possibly being more important than the mere number of species.

We studied the effects of tree species richness on speciesspecific and mixed-species litter decomposition and included the influence of mesofauna and macrofauna to investigate the mechanistic effects of the leaf litter richness - decomposition effects. Ou study has been conducted in the Hainich National Park, Centra Germany, which is exceptionally rich in deciduous forest tree species regarding European standards (up to 14 tree species pe hectare) within the framework of a long-term research project (Guckland et al., 2009; Leuschner et al., 2009). Along a gradient of a decreasing proportion of the European beech (Fagus sylvatica), the predominant tree species in temperate deciduous forests of Central Europe, plots with increasing numbers of five other broad-leaved tree species (Fraxinus excelsior, Tilia spp., Acer pseudoplatanus, Acer platanoides, and Carpinus betulus) where chosen.

The increasing abundance of leaf litter with higher degradability and better litter quality along the diversity levels can promote higher soil fauna diversity and create more favourable conditions for decomposition and nutrient release. Therefore, we hypothesized that (i) in mixed-species stands, the nutrient release rates will be higher than in pure beech stands, and (ii) nutrient release rates of the individual tree species will be higher in the multispecific stands compared to monospecific beech stands.

\section{Materials and methods}

\subsection{Study area and sampling design}

We conducted the study in the Hainich National Park, Thuringia, Central Germany, in old-growth deciduous forest stands differing in tree species diversity. The forest stands are situated in the northeastern part of the National Park at an elevation of about $350 \mathrm{~m}$ a.s.l. $\left(51^{\circ} 04^{\prime} \mathrm{N}, 10^{\circ} 30^{\prime} \mathrm{E}\right)$. The mean annual temperature is $7.5^{\circ} \mathrm{C}$. The mean annual precipitation ranges from $600 \mathrm{~mm}$ to $670 \mathrm{~mm}$, with approximately $65 \%$ falling during the 7 -months vegetation period. Soils are Luvisols with stagnic properties, developed from Pleistocene loess and underlain by limestone (Triassic Upper Muschelkalk formation) (FAO, 2006). They are characterized by high silt content (about $75 \%$ ) and have a loess cover of at least $60 \mathrm{~cm}$ (Guckland et al., 2009)
Three stand types differing in the diversity level (DL) of tree taxa were selected: one stand type with European beech (F. sylvatica L., DL 1); one type of stand mainly consisting of beech, lime (Tilia cordata Mill. and Tilia platyphyllos Scop.) and ash (F. excelsior L.) (DL 2); and one stand type with beech, lime, ash, hornbeam (C. betulus L.) and maple (A. pseudoplatanus L. and A. platanoides L.) (DL 3) as the predominant tree taxa. Stand characteristics, including the proportion of the individual tree species in the canopy cover, are given in Table 1. At each diversity level (stand type), three plots with a central area of $50 \mathrm{~m} \times 50 \mathrm{~m}$ were fenced to exclude wild boar and game. All plots were comparable regarding slope, physical soil conditions and stand structure (Guckland et al., 2009). Within each plot, three 30-m transects with two randomly selected subplots $(6 \mathrm{~m} \times 5 \mathrm{~m})$ were installed for vegetation studies and zoological investigations.

\subsection{Litter collection and litterbag construction}

At each site, freshly fallen leaves were collected with litter collectors (aperture: $0.29 \mathrm{~m}^{2}$ ) during peak litterfall in October 2005 . The leaves were separated into species and oven-dried at $25^{\circ} \mathrm{C}$ for two days, or until constant mass. Two types of litterbags were prepared: small litterbags with a size of $9 \mathrm{~cm} \times 11 \mathrm{~cm}$, and large litterbags with a size of $20 \mathrm{~cm} \times 20 \mathrm{~cm}$. Both litterbag types had a mesh size of $5 \mathrm{~mm}$. This mesh size allows macrofauna to enter the litterbags and we therefore measure leaf litter disappearance instead of the mere litter decomposition from the bags. Small litterbags were filled with $2 \mathrm{~g}( \pm 0.02 \mathrm{~g}$; exact mass determined with 2 decimals) of single-species leaves of $F$. sylvatica, F. excelsior, Tilia spp., C. betulus, A. pseudoplatanus and A. platanoides (mono litterbags) sampled from all plots of the trees' occurrence. Large litterbags were filled with $8 \mathrm{~g}( \pm 0.02 \mathrm{~g}$; exact mass determined with 2 decimals) of a litter mixture representative of the leaf litter composition of the respective plot at the end of October 2005 (mixed litterbags).

A total of 1944 mono and 324 mixed litterbags were deployed on 18th of November 2005, whereas three litterbags per litterbag type were kept in the laboratory to determine the initial dry mass (oven-dried at $70^{\circ} \mathrm{C}$ ). Overall, 42 litterbags ( 6 tree species +1 mixed litterbag, for resampling on six dates) were randomly placed on each of the six subplots at the nine fenced plots. All litterbags were arranged in two rows on the litter layer surface and covered with freshly fallen leaves. Litterbags were collected in 2005 on 15th December, in 2006 on 27th March, 19th June and 26th September, and in 2007 on 24th April and 18th September. On every sampling date, six replicates of each type of litterbag were removed (one per subplot and site). Each resampled litterbag was brushed clear of external soil and litter and the litter of the mixed litterbags was separated into species. Litterbags were handled with great care during removal and each bag was carefully transported in a separate plastic bag to minimize the loss of small litter fragments from

Table 1

Stand characteristics of the three diversity levels (DL) (means $\pm 1 \mathrm{SE}$ of three plots per DL). Different letters indicate significant differences between DL; $P<0.05$.

\begin{tabular}{lrcr}
\hline & DL 1 & DL 2 & \multicolumn{1}{c}{ DL 3 } \\
\hline $\begin{array}{l}\text { Shannon index for tree genera } \\
\text { (crown area) }\end{array}$ & $0.2 \pm 0.1 \mathrm{c}$ & $1.0 \pm 0.1 \mathrm{~b}$ & $1.4 \pm 0.0 \mathrm{a}$ \\
Canopy cover Fagus sylvatica (\%) & $96.1 \pm 1.9 \mathrm{a}$ & $67.1 \pm 3.5 \mathrm{~b}$ & $21.4 \pm 13 \mathrm{c}$ \\
Canopy cover Tilia spp. (\%) & $0.8 \pm 0.8 \mathrm{~b}$ & $13.1 \pm 5.3 \mathrm{ab}$ & $40.3 \pm 11 \mathrm{a}$ \\
Canopy cover Fraximus excelsior (\%) & $0.5 \pm 0.5 \mathrm{a}$ & $14.2 \pm 3.9 \mathrm{a}$ & $10.7 \pm 4.3 \mathrm{a}$ \\
Canopy cover Acer pseudoplatanus (\%) & $0.5 \pm 0.5 \mathrm{a}$ & $2.2 \pm 0.5 \mathrm{a}$ & $3.6 \pm 2.2 \mathrm{a}$ \\
Canopy cover Acer platanoides (\%) & $0.3 \pm 0.3 \mathrm{a}$ & $2.4 \pm 1.1 \mathrm{a}$ & $4.6 \pm 2.4 \mathrm{a}$ \\
Canopy cover Carpinus betulus (\%) & $0.0 \pm 0.0 \mathrm{~b}$ & $0.0 \pm 0.0 \mathrm{~b}$ & $14.7 \pm 5.2 \mathrm{a}$ \\
Leaf biomass $\left(\mathrm{Mg} \mathrm{ha}^{-1}\right)$ & $3.3 \pm 0.0 \mathrm{a}$ & $3.7 \pm 0.1 \mathrm{a}$ & $3.5 \pm 0.2 \mathrm{a}$ \\
Thickness of litter layer (cm) & $2.8 \pm 0.1 \mathrm{a}$ & $2.4 \pm 0.0 \mathrm{~b}$ & $1.9 \pm 0.1 \mathrm{c}$ \\
Soil pH $(0-5 \mathrm{~cm})\left(\mathrm{CaCl}_{2}\right)$ & $3.9 \pm 0.1 \mathrm{c}$ & $5.0 \pm 0.0 \mathrm{~b}$ & $5.7 \pm 0.1 \mathrm{a}$ \\
Litter pH $\left(\mathrm{CaCl}_{2}\right)$ & $4.9 \pm 0.2 \mathrm{~b}$ & $6.1 \pm 0.1 \mathrm{a}$ & $6.1 \pm 0.2 \mathrm{a}$ \\
\hline
\end{tabular}




\section{Chapter 5}

the litterbags. All leaves were oven-dried at $70{ }^{\circ} \mathrm{C}$ and weighed. Mass loss was calculated as the difference between the initial dry mass and the actual dry mass of leaves at each sampling date. Due to the small sample amount, ash analysis could not be conducted. However, calculated $k$ values for carbon disappearance did not change the results obtained for whole litter (mixed litterbags as well as single litter species).

\subsection{Physico-chemical analyses and microbial activity}

For each sampling date, total carbon and nitrogen contents were determined in pulverized litter material (Siebtechnik $\mathrm{GmbH}$, TS 1000, Mühlheim an der Ruhr, Germany; $940 \mathrm{rpm}$ ) from all leaves of the litterbags ( $\max 8 \mathrm{~g}$ ) by an automated $\mathrm{C}$ and $\mathrm{N}$ analyzer (Heraeus Elementar Vario EL, Hanau, Germany). Nutrient concentrations were analyzed by ICP-AES (Spectro, Kleve, Germany) after pressure digestion with nitric acid. We used $300 \mathrm{mg}$ sample material and $3 \mathrm{ml}$ of $65 \% \mathrm{HNO}_{3}$ in $50 \mathrm{ml}$ teflon containers. The material was digested for $10 \mathrm{~h}$ at $180{ }^{\circ} \mathrm{C}$. Samples were filtered and rinsed with double distilled $\mathrm{H}_{2} \mathrm{O}$ (final total extraction fluid: $100 \mathrm{ml}$ ).

On 11th May 2005, 3rd August 2005, 23rd November 2005 and 23rd February 2006, small litter and soil samples ( $5 \mathrm{~cm}$ depth) were taken to measure $\mathrm{pH}\left(\mathrm{CaCl}_{2}\right)$, moisture content and litter depth. The moisture content was determined gravimetrically for litter and soil separately. In addition, microbial biomass was determined by substrate-induced respiration (SIR; Anderson and Domsch, 1978) using an $\mathrm{O}_{2}$ micro-compensation apparatus (Scheu, 1992). Fresh material equivalent to $0.5 \mathrm{~g}$ (L/Of) and $5.0 \mathrm{~g}$ (Ah) dry weight was analyzed. $40 \mathrm{mg}$ of glucose were added to each sample and the microbial respiratory response was measured at hourly intervals for $20 \mathrm{~h}$ at $22{ }^{\circ} \mathrm{C}$. SIR results were converted to microbial biomass carbon $\left(C_{\text {mic }}\right)$ using the formula established for the respirometer system in use (Beck et al., 1997). Temperature $5 \mathrm{~cm}$ above ground was recorded continuously with one datalogger per plot (HOBO RH/ Temp H08-32-08; Onset Computer Corporation, Bourne, USA). The annual mean was calculated for 2006.

\subsection{Soil fauna}

Soil cores (L/Of-layer plus the uppermost $5 \mathrm{~cm}$ of the mineral soil) with a diameter of $21 \mathrm{~cm}$ for the macrofauna and $5 \mathrm{~cm}$ for the mesofauna were taken from every subplot $(n=6$ per plot and soil fauna category). Each sample was separated into litter layer and mineral soil and animals were extracted by heat using a modified high-gradient canister method (Schauermann, 1982). Slowly increasing heat from above $\left(20^{\circ} \mathrm{C}\right.$ up to $50{ }^{\circ} \mathrm{C}$ (mesofauna) or $55^{\circ} \mathrm{C}$ (macrofauna) over 12 days) and steady cooling from the bottom create a temperature and desiccation gradient that drives the animals into a collecting vessel. The animals were captured in glycol and transferred to $70 \%$ alcohol after extraction. The individuals were counted and we calculated the annual mean (numbers were given in individuals per $\mathrm{m}^{2}$ ). Our focus was on Collembola and Acari, main groups of the soil mesofauna, and Isopoda and Lumbricidae, main groups of the soil macrofauna. All these groups influence decomposition processes via grazing on the microflora and macrofauna groups additionally contribute to the breakdown of leaf litter (Schaefer, 1990).

\subsection{Calculation of decomposition rates and statistical analysis}

Mass loss is expressed as the percentage of total initial dry mass, and litter chemistry data are expressed as the percentage of total leaf dry mass. We used a graphical method and modelled the best fit for each decay curve. Overall, exponential models had the highest $R^{2}$-values. However, as residuals showed no trend, the use of linear models would also be possible. We determined the decomposition rates $(k)$ for each litter species by fitting exponential curves to remaining litter mass over 1.83 years ( 22 months). For a better comparison with other studies, we calculated annual $k$-values' with $t=1$ for one year as:

$$
M_{t}=M_{0} * \mathrm{e}^{-k t} \text {. }
$$

Nutrient release in $\%$ was calculated as:

$$
\left(C_{0} \times M_{0}\right) /\left(C_{t} \times M_{t}\right) \times 100
$$

where $M_{t}$ is the dry mass of the decomposed leaf litter at time $t, M_{0}$ is the initial dry mass of the litter, $C_{0}$ is the initial concentration of the nutrient, and $C_{t}$ is the concentration of the nutrient at sampling time $t$.

Statistical analyses were conducted using SAS 9.1 (SAS Institute Inc., Cary, NC, USA), and Statistica 8.0 (StatSoft Inc., Tulsa, OK, USA). If not stated otherwise, means and standard errors of 3 plots per diversity level were calculated. To examine differences among the diversity levels (DL 1-3), we used a Kruskal-Wallis single factor analysis of variance followed by non-parametric Mann-Whitney two sample $U$-tests ( $p<0.05$ in all analyses). Relationships between the decomposition rate as the dependent variable and the predictor variables tree diversity (Shannon index), litter layer thickness, $\mathrm{pH}$ and water content of litter and soil, microbial biomass in litter and soil, earthworm abundance and woodlice (isopod) abundance were analyzed using Spearman's rank correlation. The correlation analysis was performed with mean values of the individual tree species (mono bags) from all nine plots. Correlations of the length of time lag before $\mathrm{N}$ release (days of incubation time) with initial $\mathrm{C} / \mathrm{N}, \mathrm{C} / \mathrm{P}$ and $\mathrm{N} / \mathrm{P}$ ratios and fauna abundances were conducted using data from all nine plots. We are aware that our statistical approach involves the risk of type I error inflation, and would have called for some kind of Bonferroni-correction. This is, however, under heavy discussion and may lead to overly conservative tests (García, 2004; Roback and Askins, 2005). Due to the exploratory nature of our studies, we thus used raw p-values, but discuss these with some caution.

\section{Results}

\subsection{Litter decomposition}

In the tree species studied, the litter decay exhibited a negative exponential course except for Fagus, whose litter was decomposed at an almost linear rate. After seven (mono litterbags) and ten (mixed litterbags) months of incubation, the decomposition of Fagus litter was significantly higher at DL 3 compared to DL 1 and DL 2 (Fig. 1). For the entire investigation period, Fagus had the lowest $k$ values (approximately 0.6 ), followed by Acer spp., Tilia spp.. $C$. betulus and $F$. excelsior (Fig. 1, 2). Significant differences between the different diversity levels were found for all tree species, except for $F$. excelsior, with significantly higher decomposition rates at DL 3 compared to DL 1 . The mixed-species litterbags exhibited a significantly higher mass loss at the mixed species stands DL 2 and DL 3 (Fig. 2). After 7 months, all three diversity levels differed significantly. At the end of the experiment (after 22 months), $60 \%$ of the initial litter mass at the beech-dominated DL 1 stands and $90 \%$ of the initial litter mass at the highly diverse mixed-species stands (DL 3) were decomposed or removed from the bags.

\subsection{Soil fauna and microbial biomass}

In the beech-dominated DL 1 stands, we found almost the threefold amount of mesofauna compared to DL 3 (Table 2). 
Nutrient release

M. Jacob et al. / Soil Biology \& Biochemistry 41 (2009) 2122-2130

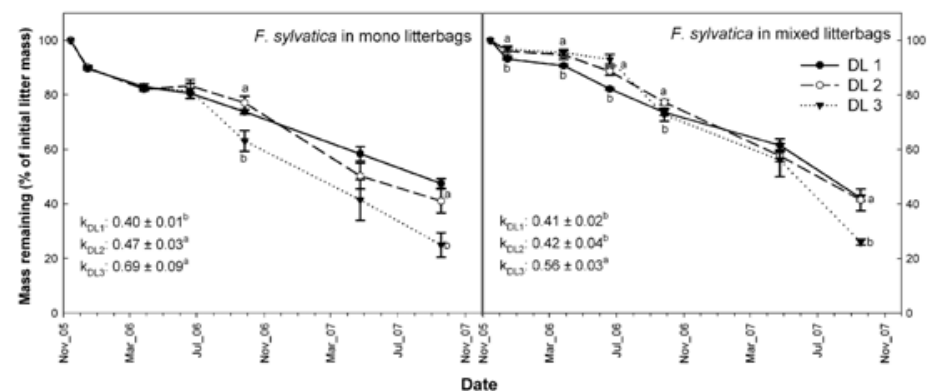

Fig. 1. Mass loss and decay constant $k\left(\mathrm{y}^{-1}\right)$ of Fagus sylvatica in mono litterbags and mixed litterbags in different diversity levels (DL) (means $\pm 1 \mathrm{SE}$ of three plots per DL). Different letters indicate significant differences between the $\mathrm{DL}(P<0.05)$,

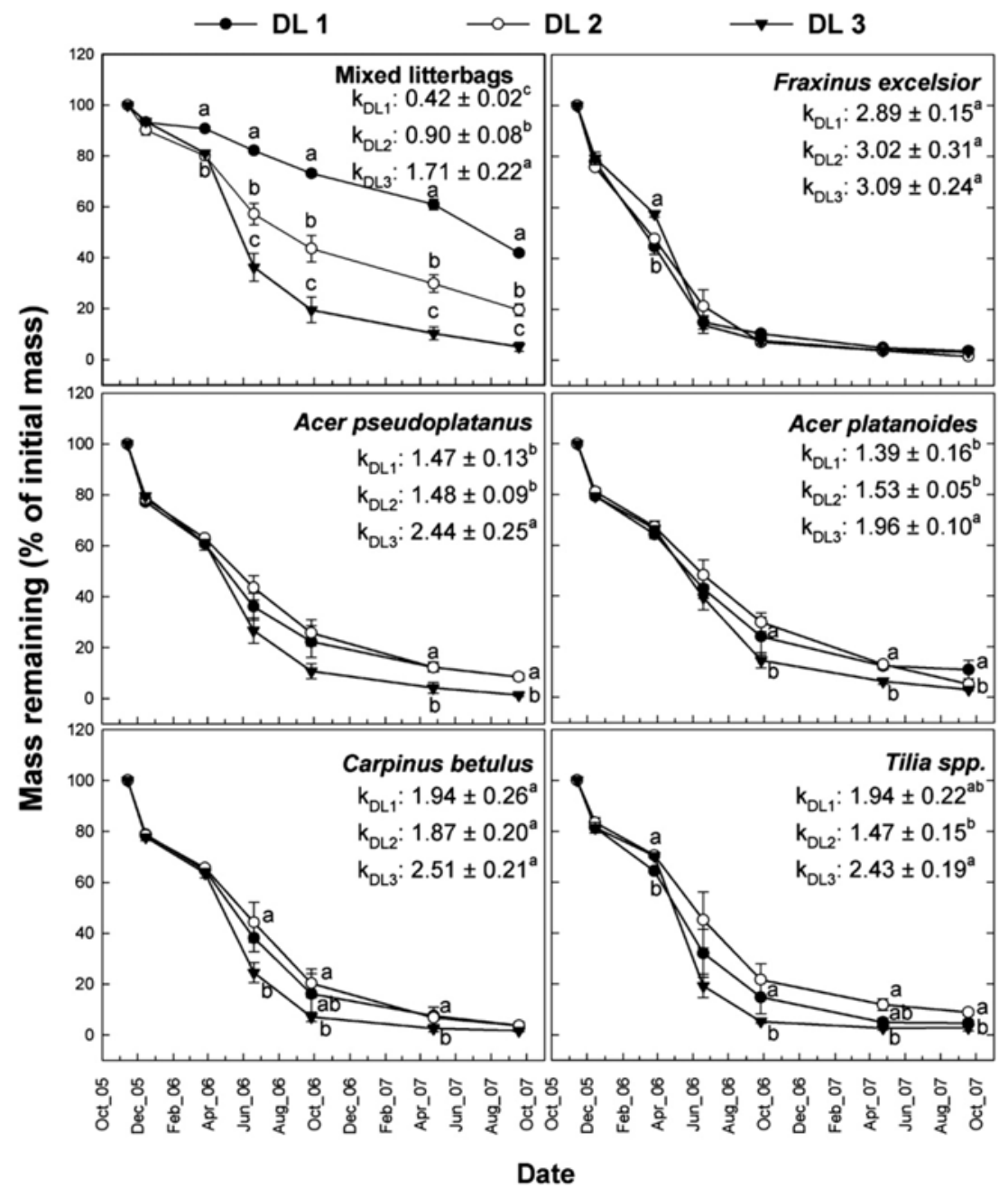

Fig. 2. Mass loss and decay constant $k\left(\mathrm{y}^{-1}\right)$ of mixed litterbags and five studied tree species in different diversity levels (DL) (means \pm 1 SE of three plots per DL). Different letters indicate significant differences between the $\mathrm{DL}(P<0.05)$. 


\section{Chapter 5}

Table 2

Microbial biomass ( $\mu \mathrm{g} \mathrm{C}_{\text {mic }} \mathrm{g}^{-1} \mathrm{dm}^{-1}$ ) and decomposer fauna abundances (individuals $\mathrm{m}^{-2}$ ). Given are annual means of three plots and standard error. Different letters indicate significant differences between diversity levels $(P<0.05)$.

\begin{tabular}{lccc}
\hline & DL 1 & DL 2 & DL 3 \\
\hline $\begin{array}{l}\text { Microflora } \\
\text { litter layer }\end{array}$ & $10020 \pm 638 \mathrm{a}$ & $10588 \pm 425 \mathrm{a}$ & $9886 \pm 307 \mathrm{a}$ \\
soil $(5 \mathrm{~cm})$ & $596 \pm 94 \mathrm{~b}$ & $886 \pm 55 \mathrm{a}$ & $1068 \pm 68 \mathrm{a}$ \\
$\begin{array}{l}\text { Mesofauna } \\
\text { Collembola }\end{array}$ & $90708 \pm 7364 \mathrm{a}$ & $52802 \pm 8125 \mathrm{~b}$ & $34167 \pm 8878 \mathrm{~b}$ \\
Acari & $123454 \pm 11690 \mathrm{a}$ & $47500 \pm 3904 \mathrm{~b}$ & $36309 \pm 2161 \mathrm{~b}$ \\
$\begin{array}{l}\text { Macrofauna } \\
\text { Isopoda }\end{array}$ & $107 \pm 36 \mathrm{~b}$ & $314 \pm 73 \mathrm{a}$ & $410 \pm 17 \mathrm{a}$ \\
Lumbricidae & $125 \pm 17 \mathrm{~b}$ & $105 \pm 15 \mathrm{~b}$ & $210 \pm 15 \mathrm{a}$ \\
\hline
\end{tabular}

In contrast, macrofauna significantly increased with increasing tree species diversity due to the double number of Lumbricidae and the fourfold number of Isopoda at DL 3 compared to DL 1 . In the uppermost $5 \mathrm{~cm}$ of the soil, microbial biomass was significantly lower in the DL 1 stands compared to the other stand types. However, microbial biomass was not different in the leaf litter layer of all stands.

\subsection{Element concentrations, element ratios and nutrient} release rates

Leaf litter of $F$. sylvatica displayed lower concentrations of most nutrients and higher C-related ratios than the other tree species (Table 3). The highest $\mathrm{N}$ and $\mathrm{P}$ concentrations of the leaf litter were found in Fraxinus. A. pseudoplatanus leaf litter was rich in $\mathrm{Ca}$ and Mg. Tilia, Carpinus and A. platanoides had intermediate nutrient concentrations, except for high $\mathrm{K}$ values in A. platanoides.

The changes in the amounts and ratios of nutrients during the 22 months of incubation time relative to the initial values are presented in Figs. 3 and 4. We do not show values for all tree species studied, as curves for $A$. platanoides and A. pseudoplatanus were very similar, and $C$. betulus showed patterns very similar to the fast decomposing Tilia species. For most nutrients and tree species, we found an exponential nutrient release right from the beginning of leaf litter decomposition. For $\mathrm{N}$ and $\mathrm{P}$, nutrient accumulation (immobilization) was found in F. sylvatica and to a smaller extent also in Tilia (Fig. 3). In Fagus, $\mathrm{N}$ and $\mathrm{P}$ amounts decreased during the first few months at DL 1 and DL 2 and increased afterwards to maximum values of 140-200\%. Finally, a decrease started 7-10 months after incubation until the values levelled off. The $\mathrm{C} / \mathrm{N}$ and $\mathrm{C} / \mathrm{P}$ ratios showed a steep linear decrease during the first year of decomposition and were almost constant in the second year. Differences between DL did not occur in Fagus, but most of the other species had lower $\mathrm{C} / \mathrm{N}$ and $\mathrm{C} / \mathrm{P}$ values in DL 1 and DL 2 stands compared to DL 3 stands. The release rates of $\mathrm{K}, \mathrm{Mg}$ and $\mathrm{Ca}$ were high in all tree species and particularly high in Fraxinus (Fig. 4).
In mixed litterbags, patterns of nutrient release were shaped by the predominant tree species. In DL 1, which consisted of almost pure beech leaf litter, patterns were similar to Fagus. DL 2 and DL 3 values decreased after four months according to their main components Tilia and Fraxinus.

\subsection{Effects of site factors, soil biota and nutrient concentrations} of the litter on litter decomposition and nutrient release

The decomposition rate constant $k$ of Fagus, A. pseudoplatanus and $A$. platanoides correlated positively with the Shannon index of the crown area, the $\mathrm{pH}$ values of the topsoil and correlated negatively with the litter layer thickness (Table 4). There was no relationship between $k$ and the $\mathrm{pH}$ value of the organic surface layer. In the litter of most tree species, $k$ was positively correlated with the abundance of Lumbricidae, but only the decay of Fagus litter was correlated with the abundance of Isopoda. Fraxinus was the only tree species whose $k$ values did not correlate with any predictor variable. In general, the high $k$ values of Fraxinus, Tilia and Carpinus did not or only weakly correlate with the predictor variables, whereas the $k$ values of the more slowly decomposing litter of A. pseudoplatanus and A. platanoides were more dependent on environmental variables. In particular, the $k$ value of the very slowly decomposing Fagus litter was also negatively correlated with the thickness and the water content of the litter layer and the microbial biomass in the soil.

In the litter of the individual tree species as well as in the litter mixtures, the temporal patterns of nutrient release were correlated with the initial C- and $\mathrm{N}$-related ratios and the abundance of Collembola, Acari, Lumbricidae and Isopoda (Table 5). In Fagus and Fraxinus, the length of the time lag before $\mathrm{N}$ release was significantly correlated with the initial $\mathrm{C} / \mathrm{N}$ and $\mathrm{C} / \mathrm{P}$ ratios of the litter (and with the initial N/P ratio in the case of Fraxinus). The other tree species showed no significant correlation between the length of the time lag before $\mathrm{N}$ release and initial nutrient ratios of the litter. In the litter mixtures, the duration of the lag phase was only correlated with the litter's initial $\mathrm{C} / \mathrm{N}$ ratio. The temporal pattern of $\mathrm{P}$ release was correlated with initial C/N, C/P and N/P ratios in Fraxinus, initial C/P and $\mathrm{N} / \mathrm{P}$ ratios in Tilia and the initial $\mathrm{C} / \mathrm{N}$ ratio of the litter mixture. With regard to P release, we found no such correlations in Fagus.

\section{Discussion}

\subsection{Species richness effects on decomposition and nutrient release}

Litterbags with stand-specific (of up to six tree species) litter mixtures decomposed significantly faster with increasing tree species richness. This finding is in accordance with about half of all mixed litterbag studies, which found rates of mass loss being higher in litter mixtures than in single-species litter despite unaltered climatic conditions and litter chemistry (Gartner and Cardon, 2004; Hättenschwiler et al., 2005). It should be noted, however, that in the

Table 3

Initial nutrient concentrations ( $\mathrm{mg} \mathrm{g}_{\mathrm{DM}}^{-1}$ ) of tree litter of all main tree species (mono litterbags, $N=1$ ) and mixed litterbags (means $\pm 1 \mathrm{SE}, N=3$ ).

\begin{tabular}{lllllllll}
\hline & $\mathrm{C} / \mathrm{N}$ & $\mathrm{C} / \mathrm{P}$ & $\mathrm{N} / \mathrm{P}$ & $\mathrm{N}$ & $\mathrm{P}$ & $\mathrm{K}$ & $\mathrm{Ca}$ \\
\hline Fagus sylvatica & 56.06 & 1303 & 23.25 & 8.30 & 0.36 & 5.67 & 16.80 \\
Fraxinus excelsior & 27.60 & 631 & 22.86 & 15.65 & 0.69 & 8.77 & 28.83 \\
Tilia spp. & 37.93 & 720 & 18.96 & 11.89 & 0.63 & 8.03 & 2.21 \\
Carpinus betulus & 40.08 & 729 & 18.22 & 11.02 & 0.61 & 6.24 & 2.87 \\
Acer pseudoplatanus & 36.40 & 921 & 25.40 & 11.72 & 0.47 & 7.30 & 21.49 & 30.15 \\
Acer platanoides & 36.53 & 684 & 18.71 & 11.78 & 0.63 & 10.45 & 2.58 \\
Mix (DL 1) & $47.70 \pm 3.33$ & $993 \pm 41$ & $21.00 \pm 1.14$ & $9.72 \pm 0.65$ & $0.46 \pm 0.02$ & $4.55 \pm 0.56$ & $14.09 \pm 0.50$ & 2.17 \\
Mix (DL 2) & $37.42 \pm 0.61$ & $791 \pm 26$ & $21.36 \pm 0.66$ & $12.29 \pm 0.16$ & $0.58 \pm 0.02$ & $7.58 \pm 0.44$ & $22.12 \pm 1.33$ & $1.75 \pm 0.08$ \\
Mix (DL 3) & $34.68 \pm 2.39$ & $705 \pm 43$ & $20.72 \pm 1.87$ & $13.21 \pm 0.85$ & $0.64 \pm 0.04$ & $6.91 \pm 0.24$ & $27.34 \pm 2.07$ & $2.38 \pm 0.33$ \\
\hline
\end{tabular}


Nutrient release

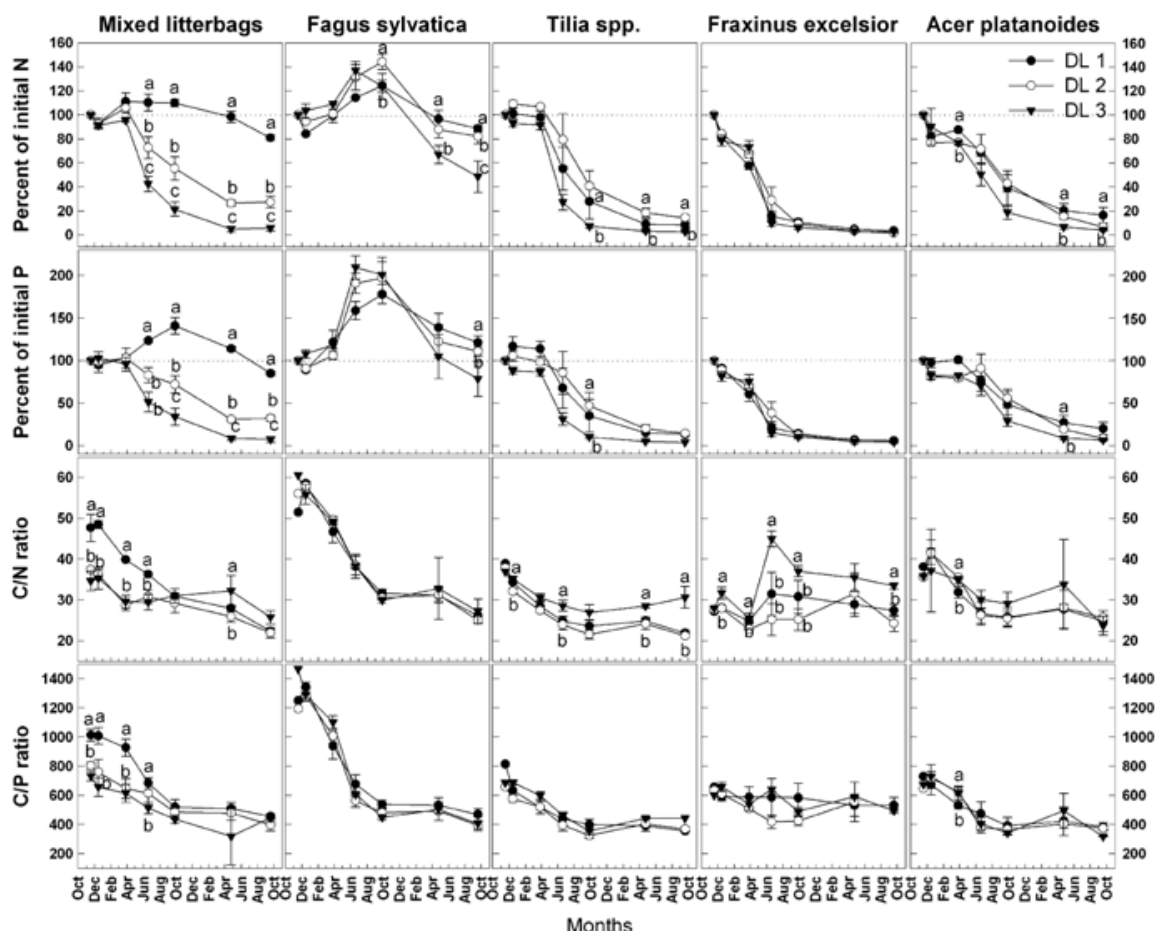

Fig. 3. Remaining amounts of $N$ and $P$ relative to the initial values, and changes in the $C / N$ and $C / P$ ratios $\left(\mathrm{g} \mathrm{g}^{-1}\right)$, in mixed and mono litterbags (containing litter of individual tree species) during decomposition (means $\pm 1 \mathrm{SE}$ of three plots per $\mathrm{DL}$ ).

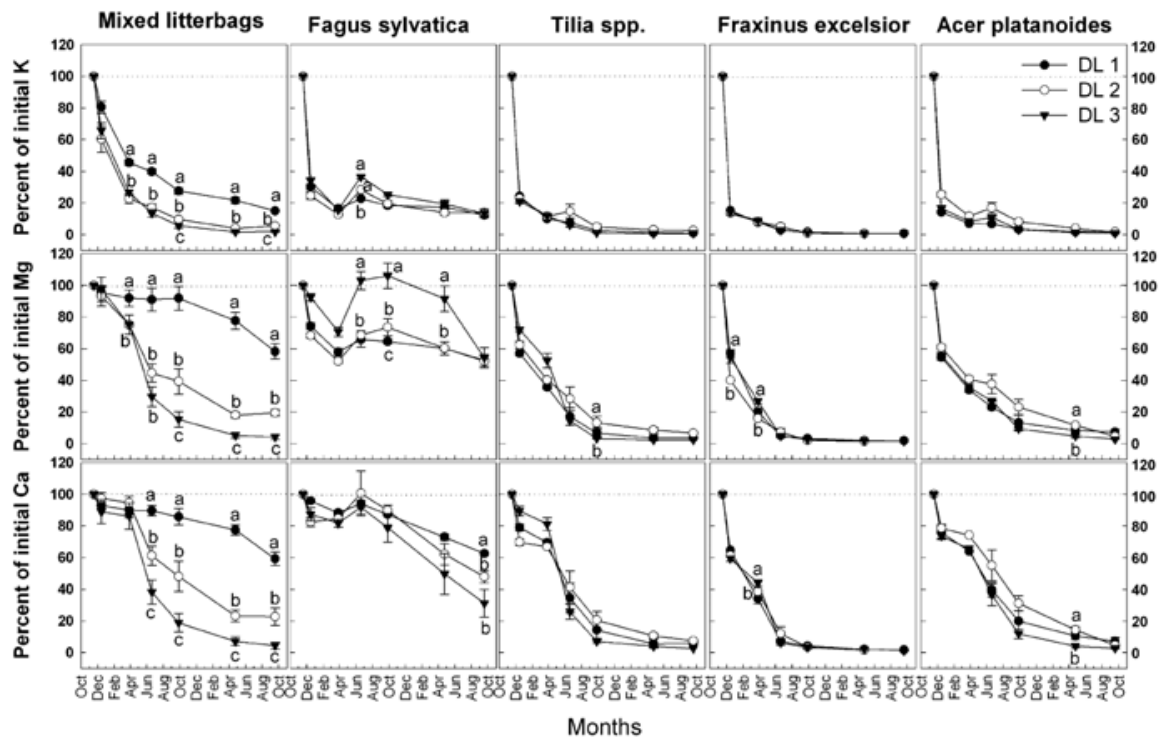

Fig. 4. Remaining amounts of $\mathrm{Na}, \mathrm{Mg}$, and Ca relative to the initial values in mixed and mono litterbags (containing litter of individual tree species) during decomposition (means $\pm 1 \mathrm{SE}$ of three plots per DL). 


\section{Chapter 5}

Table

Spearman's rank correlation coefficients (rho) for correlations between the decomposition constants $k\left(\mathrm{y}^{-1}\right)$ of the litter of individual tree species and species mixtures (response variable) and different environmental predictor variables $(N=9)$.

\begin{tabular}{|c|c|c|c|c|c|c|c|c|c|c|}
\hline & $\begin{array}{l}\text { Shannon } \\
\text { Index } \\
\text { (crown area) }\end{array}$ & $\begin{array}{l}\text { Thickness } \\
\text { litter layer } \\
(\mathrm{cm})\end{array}$ & $\begin{array}{l}\text { Litter } \\
\mathrm{pH}\end{array}$ & $\begin{array}{l}\text { Soil pH } \\
(0-5 \mathrm{~cm})\end{array}$ & $\begin{array}{l}\text { Litter layer } \\
\text { water } \\
\text { content (\%dm) }\end{array}$ & $\begin{array}{l}\text { Soil water } \\
\text { content } \\
\text { (\%dm) }\end{array}$ & $\begin{array}{l}\text { Microbial biomass } \\
\text { (litter) } \\
\left(\mu \mathrm{g} \mathrm{Cmic}^{-1} \mathrm{dm}^{-1}\right)\end{array}$ & $\begin{array}{l}\text { Microbial biomass } \\
\text { (soil) } \\
\text { ( } \mu \mathrm{g} \mathrm{Cmic} \mathrm{g}^{-1} \mathrm{dm}^{-1} \text { ) }\end{array}$ & $\begin{array}{l}\text { Lumbricidae } \\
\text { abundance } \\
\text { (ind } \mathrm{m}^{-2} \text { ) }\end{array}$ & $\begin{array}{l}\text { Isopoda abundance } \\
\text { (ind } \mathrm{m}^{-2} \text { ) }\end{array}$ \\
\hline Fagus sylvatica & $0.93^{* *}$ & $-0.93^{* *}$ & 0.62 & $0.83^{\circ}$ & $0.68^{*}$ & 0.43 & -0.18 & $0.82^{*}$ & 0.42 & $0.82^{*}$ \\
\hline Fraxinus excelsior & 0.38 & -0.38 & 0.32 & 0.15 & 0.25 & -0.28 & -0.13 & 0.05 & -0.20 & 0.13 \\
\hline Carpinus betulus & 0.53 & -0.53 & -0.05 & 0.40 & -0.10 & -0.07 & -0.18 & 0.35 & $0.75^{*}$ & 0.17 \\
\hline A. pseudoplatamus & $0.73^{\circ}$ & $-0.73^{\circ}$ & 0.23 & $0.67^{\circ}$ & 0.25 & 0.27 & -0.22 & 0.57 & $0.88^{* *}$ & 0.43 \\
\hline A. platanoides & $0.73^{\circ}$ & $-0.73^{\circ}$ & 0.25 & $0.67^{*}$ & 0.18 & 0.05 & -0.32 & 0.58 & $0.87^{* *}$ & 0.43 \\
\hline
\end{tabular}

majority of the litter mixture experiments, the mixtures are composed of equal amounts of the individual litter species, whereas in our study, we used site-representative mixtures that contained unequal amounts of litter from the individual tree species. These differences in the approach put the comparability of the results into perspective.

In a comparable study, Hättenschwiler and Gasser (2005) observed a significantly increased mass loss from litter mixtures (on average, 10\% compared with the predicted values from the corresponding monocultures) of up to six tree species that included most of the species investigated in the present study.

Previous studies in the area have shown a significant impact of tree species richness on chemical soil properties such as soil $\mathrm{pH}$, base saturation and cation exchange capacity, with lowest values in the monospecific stands (Guckland et al., 2009). These effects were correlated to the gradient of beech abundance along the forest stands.

Generally, microorganisms are important controllers of decomposition and mineralization (Lavelle and Spain, 2001), but the meso- and macrofauna affect these processes through their grazing pressure on the microflora (Schaefer, 1990; Kautz and Topp. 2000, Cragg and Bardgett, 2001). In our study, we found a lower pH, a lower microflora biomass in the upper soil, a thicker litter layer and significantly higher mesofauna abundance in the beech stands compared to the mixed-species stands. A litter layer being thicker throughout the year is an important habitat for soil fauna and keeps moisture as well as temperature rather constant. The reduced thickness of the litter layer, in combination with a high earthworm feeding activity, is probably an important reason for the low number of the mesofauna on the diverse stands (cf. Maraun et al., 2003).

Macrofauna presence can change not only litter mass loss, but most importantly, the relationship between litter mass loss and litter diversity can be strongly influenced by animals (Hättenschwiler and Gasser, 2005). Earthworms additionally influence decomposition and mineralization through structural impacts on the litter and soil matrix (Marhan and Scheu, 2006; Postma-Blaauw et al., 2006). Comparing the decomposition of different litter mixtures, Schädler and Brandl (2005) found a large influence of the fauna on decomposition, although the effect changed with litter type. The positive effects of the soil fauna on decomposition were highest in $\mathrm{N}$ rich and $\mathrm{C}$ poor litter. The significantly higher decay rate in the more diverse forest stands of our study was probably due to the combined effect of higher earthworm abundance, better litter quality and elevated soil $\mathrm{pH}$ values. The influence of litterfeeding soil animals on litter diversity could be driven by changing feeding rates as a function of litter diversity, by indirect effects on microbial or mesofauna communities, or a combination of both (Hättenschwiler and Gasser, 2005).

ncreasing species richness may not affect decomposition if litter mixtures are composed of chemically similar species. In contrast, litter mixtures composed of chemically diverse species may exhibit significant effects on decomposition, due to the positive correlation between plant species richness and increased diversity of litter compounds. Meier and Bowman (2008) found that the chemical composition of the litter mixtures was the

Table 5

Spearman's rank correlation coefficients (rho) for correlations between the temporal pattern of nitrogen $(\mathrm{N})$ and phosphorus $(\mathrm{P})$ release of the litter of individual tree species and species mixtures (response variables) and different environmental predictor variables $(N=9)$.

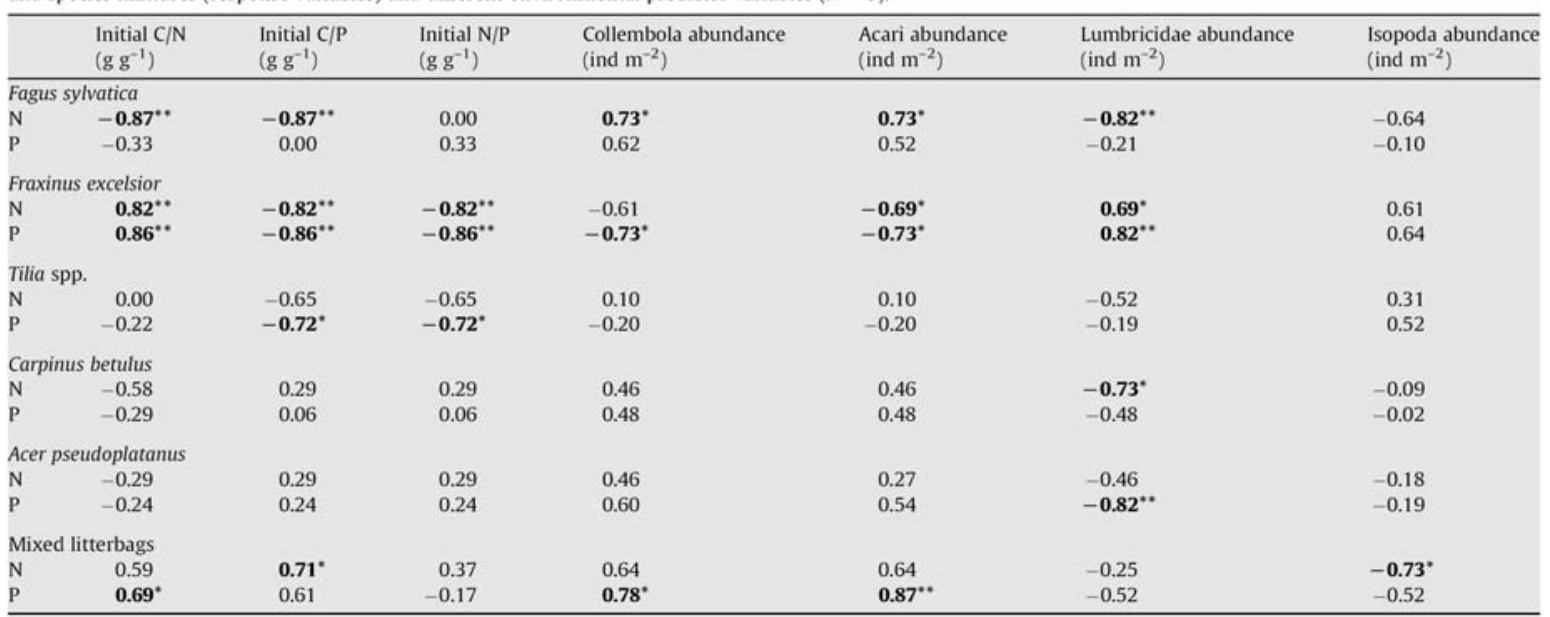


strongest predictor of soil respiration, net $\mathrm{N}$ mineralization, and microbial biomass $\mathrm{N}$. In our study, the release dynamics of all nutrients differed significantly between the diversity levels. We found lower potassium $(\mathrm{K})$ and magnesium $(\mathrm{Mg})$ release rates in the monospecific stands compared to the mixed species stands. $\mathrm{Mg}$ concentration of the leaf litter is strongly dependent on soil properties and bedrock type (Berg and Laskowski, 2006) and lower stocks of exchangeable Mg were measured in the topsoil of the DL1 stands (Guckland et al., 2009).

\subsection{Species identity effects on decomposition and nutrient release}

We found significant differences between the three diversity levels regarding the decomposition rates of the litter from individual tree species, but - in contrast to our hypothesis - not for the nutrient release rates.

In our study, the annual $k$ values of beech litter ranged from 0.4 to 0.7 and were similar to data from the literature: decomposition studies on soils with $\mathrm{pH} 3-4$ yielded annual $k$ values between 0.18 and 0.3 (e.g. Albers et al., 2004; Enriquez et al., 1993; Irmler, 2000; Hobbie et al., 2006), and rich mull sites with higher $\mathrm{pH}$ values exhibited $k$ values of $0.5-0.8$ (e.g. Seastedt, 1984; Schaefer, 1990).Hättenschwiler and Gasser (2005) found that decomposition of relatively recalcitrant litter from species such as Fagus is accelerated when other species are present, but accompanying litter species are of limited importance for changing the mass loss of more rapidly decomposing species. In Fagus, the only tree species occurring in all forest stands of this study, we found no acceleration of decomposition in mixed litterbags compared to mono litterbags.

Litter quality of the individual tree species differed particularly between the recalcitrant Fagus leaves and the fast decomposing litter of Fraxinus, Tilia and Carpinus. The typical triphasic pattern of $\mathrm{N}$ leaching, microbial immobilization and mineralization (Berg and McClaugherty, 2008) was only found in F. sylvatica and - to a small extent - in Acer species. In Tilia, Fraxinus and Carpinus, we observed an immediate $\mathrm{N}$ release after incubation and no mineralization. We possibly could not observe the initial leaching or a mineralization for fast decomposing litter, as incubation of one month for fast decomposing might be too long.

The point at which $\mathrm{N}$ release from litter begins has often been related to a particular or "critical" $\mathrm{C} / \mathrm{N}$ ratio or $\mathrm{N}$ concentration of the litter ( $\mathrm{C} / \mathrm{N}$ ratio of $25-30$, initial $\mathrm{N}$ concentration of $20 \mathrm{mg} \mathrm{g}^{-1}$ as a threshold for net accumulation or net release of $\mathrm{N}$ ) (Berg and Laskowski, 2006; Moore et al., 2006). However, critical C/N ratios appear to vary with the ecosystem and the studied tree species. Berg and McClaugherty (1987) found that $\mathrm{N}$ release can start at $\mathrm{C} / \mathrm{N}$ ratios between 29 and 80 , and concluded that the $\mathrm{C} / \mathrm{N}$ ratio is not a good predictor for the onset of net $\mathrm{N}$ release from decomposing litter. In our study, $\mathrm{N}$ release from Fagus litter started earlier in the highly diverse stands (DL 3) - with initial litter C/N ratios of about 35 in the mixed litterbags - than in the pure and intermediately diverse stands of DL 1 and DL 2 with initial C/N ratios of 40-50 in the mixed litterbags. The limited predictive power of the nutrient ratios may be due to the fact that they do not consider the quality of the $\mathrm{C}$ and $\mathrm{N}$ constituents of the litter.

In contrast to many other studies and tree species, we found no or only little accumulation of calcium (Ca) in the leaf litter but a fast Ca release from the litter of Tilia, Fraxinus and A. platanoides. Ca is known to be part of the structural plant tissue, hence its release is related to the second decomposition phase (Blair, 1988; Laskowski et al., 1995). In our study, Ca release differed between tree species but not between the diversity levels (except for Fagus after 22 months). In a previous analysis, we found decomposition rates to be positively correlated with the initial $\mathrm{Ca}$ concentration of the litter (Jacob et al., submitted for publication). In the present study, Ca release rates are also highest in the species with the highest initial Ca concentration (Fraxinus, Tilia, Acer) and slowest in Fagus, a tree species with a low initial Ca concentration of the litter.

In a recent common garden experiment with 14 different tree species (including most tree species of our study), Reich et al. (2005) found that Lumbricus terrestris was more abundant in plots of trees with a high Ca content, which, in turn, was most important for the decomposition rate. This was also found in our study, with the highest earthworm abundance, highest decomposition rates and the Ca-rich litter being present in the mixed species stands. An exclusion experiment by Staaf (1987) demonstrated the strong influence of earthworms on litter decomposition, which we could confirm in our study for all tree species studied except Fagus and Fraxinus: the decomposition rate constant $k$ of Tilia, Acer and Carpinus leaf litter as well as of the litter mixtures were positively correlated to earthworm abundance. This is consistent with findings of Hättenschwiler and Gasser (2005) showing earthworms as an important factor in determining mass loss of more rapidly decomposing leaf litter species (Tilia, Carpinus, Prumus). On the other hand, we found an overall close correlation between the decomposition rate of $F$. sylvatica litter and isopod abundance. Isopods have also been found to be positively correlated with beech litter mass loss rates in a pure beech forest. In the same study, lumbricids even showed a negative correlation to the decay rate of beech leaf litter (Irmler, 2000).

From our results, we can infer mechanistic interactions among litter quality, soil conditions, effects of soil biota and decomposition rates as follows: the European beech, which tolerates a broad range of exchangeable $\mathrm{Ca}, \mathrm{Mg}$ and $\mathrm{K}$ as well as of $\mathrm{pH}$ values in the soil (Leuschner et al., 2006), produces litter with low concentrations of $\mathrm{N}, \mathrm{Ca}$ and $\mathrm{Mg}$ and wide $\mathrm{C} / \mathrm{N}$ ratios. The resulting low litter quality prevents the establishment of large populations of lumbricids, which prefer litter with high $\mathrm{Ca}$ concentrations and small $\mathrm{C} / \mathrm{N}$ ratios. Low densities of these soil biota result in lower rates of litter decomposition and nutrient release. In combination with the low $\mathrm{Ca}$ and $\mathrm{Mg}$ concentrations of the litter, the slower release rates of these "base" cations lead to a more intense acidification of the beech stands' topsoils, which extends the decomposition process even more by affecting the species composition and the activity of the soil biota.

Thus, over decades and centuries, the European beech creates its own site conditions, which are characterized by a relatively low litter quality, a thicker litter layer, lower values of $\mathrm{pH}$ and base saturation in the topsoil (Guckland et al., 2009), and by a lower abundance of the saprophagous macrofauna that are functionally important for litter decomposition. These interactions explain the differences in the soil conditions - including the abundance and species composition of soil biota - between neighbouring mature deciduous forest stands differing in their fraction of the European beech, even if they grow on the same bedrock and under the same climatic conditions.

\subsection{Conclusion}

We could confirm the hypothesis that in the mixed species stands, the nutrient release rates are higher than in pure beech stands. Corresponding to the decomposition rates, the rates of nutrient release from the litter mixtures were significantly higher in the highly diverse DL 3 stands. On the other hand, we have to reject the hypothesis that in the mixed stands, the rates of nutrient release from the litter of the individual tree species are increased: at all levels of tree species diversity, the individual tree species exhibit similar nutrient release rates. It appears that the mere number of tree species is not the main driver for nutrient dynamics and decomposition processes. In contrast, the release of nutrients from decomposing litter seems to be largely determined by the 


\section{Chapter 5}

proportion of the European beech in the tree species composition of the stands. Owing to the chemical composition of its litter, the beech influences the chemical conditions of the soil and the composition and abundance of the soil fauna, which, in turn, interacts with the structure of the organic surface layer and the decomposition of the litter. Thus, through their species-specific traits, the presence and abundance of individual tree species appears to be more important for the dynamics of litter decomposition than the tree species diversity per se.

\section{Acknowledgements}

Funding by the Deutsche Forschungsgemeinschaft (DFG; Graduiertenkolleg 1086) is greatly acknowledged. We want to thank two anonymous reviewers for the detailed comments on previous versions of the manuscript.

\section{References}

Albers, D., Migge, S., Schaefer, M., Scheu, S., 2004. Decomposition of beech leaves (Fagus sylvatica) and spruce needles (Picea abies) in pure and mixed stands of (Fagus sylvatica) and spruce needles (Picea abies) in pure and
beech and spruce. Soil Biology \& Biochemistry 36, 155-164.

Anderson, J.P.E., Domsch, K.M., 1978. A physiological method for the quantitative measurement of microbial biomass in soils. Soil Biology \& Biochemistry 10, measurem 215 .

Beck, T., Joergensen, R.G., Kandeler, E., Makeschin, F., Oberholzer, H.R., Nuss, H.W., Scheu, S., 1997. An inter-laboratory comparison of ten different ways of measuring soil microbial biomass C. Soil Biology \& Biochemistry 29, 1023-1032. Berg. B., Laskowski, R., 2006. Litter Decomposition: A Guide to Carbon and Nutrie Turnover. Advances in Ecological Research. Elsevier, Amsterdam, pp. 421.

Berg. B., McClaugherty, C., 1987. Nitrogen release from litter in relation to the disappearance of lignin. Biogeochemistry 4, 219-224.

Berg. B., McClaugherty, C., 2008. Plant Litter - Decomposition, Humus Formation, Carbon Sequestration. Springer, Berlin, $338 \mathrm{pp}$.

Blair, J.M., 1988. Nutrient release from decomposing foliar litter of three species with special reference to calcium, magnesium and potassium dynamics. lant and Soil 110, 49-55.

Blair, J.M., Parmelee, R.W., Beare, M.H., 1990. Decay rates, nitrogen fluxes, and decomposer communities of single-species and mixed-species foliar litter. Ecology 71, 1976-1990.

Brandtberg, P.O., Lundkvist, H., 2004. Does an admixture of Betula species in Picea abies stands increase organic matter quality and nitrogen release? Scandinavian Journal of Forest Research 19, 127-141.

Côteaux, M.-M., Bottner, P., Berg. B., 1995. Litter decomposition, climate and litter quality. Tree 10, 63-66.

Cragg, R.G., Bardgett, R.D., 2001. How changes in soil faunal diversity and composition within a trophic group influence decomposition processes. Soil Biology \& Biochemistry 33, 2073-208

Enriquez, S., Duarte, C.M., Sand-Jensen, K., 1993. Patterns in decomposition rates among photosynthetic organisms: the importance of detritus $\mathrm{C}: \mathrm{N}: \mathrm{P}$ content. Oecologia 94, 457-471.

FAO, ISRIC, IUSS, 2006. World Reference Base for Soil Resources 2006. World Soil Resources Reports 103. Rome, Italy, pp. 128

García, LV . 2004. Escaping the Bonferroni iron claw in ecological studies. Oikos $105,657-663$.

Gartner, T.B., Cardon, Z.G., 2004. Decomposition dynamics in mixed-species leaf litter. Oikos 104, 230-246.

Gnankambary, Z., Bayala, J., Malmer, A., Nyberg, G., Hien, V., 2008. Decomposition and nutrient release from mixed plant litters of contrasting quality in an agroforestry parkland in the south-Sudanese zone of West Africa. utrient Cycling in Agroecosystems 82,1-13.

Guckland, A., Brauns, M., Flessa, H., Thomas, F.M., Leuschner, C., 2009. Acidity, nutrient stocks and organic matter content in soils of a temperate deciduous forest with different abundance of European beech (Fagus sylvatica L). Journal of Plant Nutrition and Soil Science. doi:10.1002/jpln.200800072.

Harguindeguy, N.P., Blundo, C.M., Gurvich, D.E., Díaz, S., Cuevas, E., 2008. More than the sum of its parts? Assessing litter heterogeneity effects on the decomposition of litter mixtures through leaf chemistry. lant Soil 303, 151-159.

Hăttenschwiler, S., Gasser, P., 2005. Soil animals alter plant litter diversity effects on decomposition. PNAS 102, 1519-1524.

Hättenschwiler, S., Tiunov, A.V., Scheu, S., 2005. Biodiversity and litter decomposition in terrestrial ecosystems. Annual Review of Ecology, Evolution, and Systematics 36, 191-218.

Hector, A., Joshi, J., Scherer-Lorenzen, M., Schmid, B., Spehn, E.M., Wacker, L. Weilenmann, M., Bazeley-White, E., Beierkuhnlein, C., Caldeira, M.C.
Dimitrakopoulos, P.G., Finn, J.A., Huss-Danell, K., Jumpponen, A., Leadley, P.W., Loreau, M., Mulder, C.P.H., Neßhöver, C., Palmborg, C., Read, D.J., Siamantziouras, A.S.D., Terry, A.C., Troumbis, A.Y., 2007. Biodiversity and ecosystem functioning: reconciling the results of experimental and observational studies. Functional Ecology 21, 998-1002.

Hobbie, S.E., Reich, P.B., Oleksyn, J., Ogdahl, M., Zytkowiak, R., Hale, C. Karolewski, P., 2006. Tree species effects on decomposition and forest floor dynamics in a common garden. Ecology 87, 2288-2297. Hooper, D.U., Chapin, F.S., Ewel, J.J., Hector, A., Inchausti, P., Lavorel, S.,
Lawton, J.H., Lodge, D.M., Loreau, M., Naeem, S., Schmid, B., Setälä, H., Symstad, A.j. Vandermeer, J., Wardle, D.A. 2005. Effects of biodiversity on Symstad, A.J.. Vandermeer, J.. Wardle, D.A., 2005. Effects of biodiversity on
ecosystem functioning: a consensus of current knowledge, cological Monographs 75, 3-35.

Irmler, U., 2000. Changes in the fauna and its contribution to mass loss and $\mathrm{N}$ release during leaf litter decomposition in two deciduous forests. Pedobiologia $44,105-118$

Jacob, M., Viedenz, K., Polle, A., Thomas, F. Leaf litter decomposition in temperate deciduous forest stands along a gradient of increasing tree species diversity. in revision.

Jonsson, M., Wardle, D., 2008. Context dependency of litter-mixing effects on decomposition and nutrient release across a long-term chronosequence. Oikos 117, 1674-1682.

Kautz, G., Topp, W., 2000. Acquisition of microbial communities and enhanced availability of soil nutrients by the isopod Porcellio scaber (Latr.) (Isopoda: Oniscidea). Biology and Fertility of Soils 31, 102-107.

Laskowski, R., Niklińska, M., Maryański, M., 1995. The dynamics of chemical elements in forest litter. Ecology 76, 1393-1406.

Lavelle, P., Spain, A.V., 2001. Soil Ecology. Kluwer Scientific Publications, Amsterdam, pp. 688 .

Leuschner, C., Jungkunst, H., Fleck, S., 2009. Functional role of forest diversity: pros and cons of synthetic stands and across-site comparisons in established forests. Basic and Applied Ecology 10,1-9.

Leuschner, C., Meier, I.C., Hertel, D., 2006. On the niche breadth of Fagus sylvatica: soil nutrient status in 50 Central European beech stands on a broad range of bedrock types. Annals of Forest Science 63, 355-368.

Maraun. M. Salamon, J.-A. Schneider, K. Schaefer, M., Scheu, S., 2003. Oribatid mite and collembolan diversity, density and community structure in a moder beech forest (Fagus sylvatica): effects of mechanical perturbations. Soil Biology \& Biochemistry 35, 1387-1394.

Marhan, S., Scheu, S., 2006. Mixing of different mineral soil layers by endogeic earthworms affects carbon and nitrogen mineralization. Biology and Fertility of Soils $42,308-314$.

McTiernan, K.B., Ineson, P., Coward, P.A., 1997. Respiration and nutrient release from tree leaf litter mixtures. Oikos 78, 527-538.

Meier, C.L., Bowman, W.D., 2008. Links between plant litter chemistry, species diversity, and below-ground ecosystem function. PNAS 105, 19780-19785.

Moore, T.R., Trofymow. J.A., Prescott, C.E., Fyles, J., Titus, B.D., CIDET Working Group. 2006. Patterns of carbon, nitrogen and phosphorus dynamics in decomposing foliar litter in Canadian forests. Ecosystems 9, 46-62.

Postma-Blaauw, M.B., Bloem, J., Faber, J.H., van Groeningen, J.W., de Groede, R.G.M. Brussaard, L., 2006. Earthworm species composition affects the soil bacterial community and net nitrogen mineralization. Pedobiologia 50, 243-256.

Reich, P.B., Oleksyn, J., Modrzynski, J., Mrozinski, P., Hobbie, S.E., Eissenstat, D.M Chorover, J., Chadwick, O.A., Hale, C.M., Tjoelker, M.G., 2005. Linking litter calcium, earthworms and soil properties: a common garden test with 14 tree species. Ecology Letters 8, 811-818.

Roback, P.J., Askins, R.A., 2005. Judicious use of multiple hypothesis tests. Conservation Biology 19, 261-267.

Schädler, M., Brandl, R., 2005. Do invertebrate decomposers affect the disappearance rate of litter mixtures. Soil Biology \& Biochemistry 37, 329-337.

Schauermann, J.. 1982. Verbesserte Extraktion der terrestrischen Bodenfauna im Vielfachgerăt modifiziert nach Kempson und Macfadyen. rbeitsberichte Sonderforschungsbereich $135,39-45$.

Schaefer, M., 1990. The soil fauna of a beech forest on limestone: trophic structure and energy budget. Oecologia 82, 128-136.

Scherer-Lorenzen, M., Schulze, E.D., Don, A., Schumacher, J., Weller, E., 2007. Exploring the functional significance of forest diversity: a new long-term experiment with temperate tree species (BIOTREE). Perspectives in Plant Ecology, Evolution and Systematics 9, 53-70.

Scheu, S., 1992. Automated measurement of the respiratory response of soil microcompartments: active microbial biomass in earthwork faeces. Soil Biology \& Biochemistry 24, 1113-1118.

Seastedt, T.R., 1984. The role of microarthropods in decomposition and mineralization processes. Annual Review of Entomology 29, 25-46.

Staaf, H., 1987. Foliage litter turnover and earthworm populations in three beech forests of contrasting soil and vegetation types. Oecologia 72, 58-64.

Swift, M.J., Heal, O.W., Anderson, J.M., 1979. Decomposition in Terrestrial Ecosystems. Blackwell, Oxford, pp. 372.

Wardle, D.A., Bonner, K.I., Nicholson, K.S., 1997. Biodiversity and plant litter: experimental evidence which does not support the view that enhanced species richness improves ecosystem function. Oikos 79, 247-258. 


\section{Chapter}

6

Nutrient stocks of five deciduous forest tree species in monospecific and mixed species forest stands

Mascha Jacob, Christoph Leuschner, Frank M Thomas 


\subsection{Abstract}

Forests are facing tremendous impacts due to the changing climate and new management schemes in European forestry. These two factors will probably lead to a more diverse tree species composition in European forests. Tree nutrition in mixtures commonly matches the nutritional status in monocultures, but nonlinear interactions can also occur and this relationship needs to be investigated. We have therefore selected forest stands with increasing tree species diversity from monocultures of European beech (diversity level 1, DL 1) to stands of beech plus two or four other deciduous tree genera ( $D L 2$ and $D L 3$ ) to investigate the concentrations of $\mathrm{N}, \mathrm{P}, \mathrm{K}, \mathrm{Mg}$ and $\mathrm{Ca}$ in the different tree compartments (stem wood, branches, stem bark, foliage and fruits) as well as the corresponding nutrient stocks.

The nutritional status in the investigated forest was good, except for P. Nutrient concentrations were generally lower in the beech compared to the other deciduous tree species. N, P, K and Mg were contained to 40-60 \% in stem wood, 10-20 \% in branches, 10$20 \%$ in stem bark, 5-15\% in fresh leaves, and 1.5-7 \% in fruits. Except for $\mathrm{N}$, the total nutrient stocks did not differ significantly among DL, although the biomasses of stem wood and branches and, therefore, the total biomass were significantly higher at $\mathrm{DL} 1$. The basal area-related stocks of all investigated nutrients and all tree compartments increased with increasing tree species diversity. They were less variable in the 'storage compartments' stem wood and branches than in the 'productivity compartments' fruits and leaves, which exhibited larger interspecific differences.

\subsection{Introduction}

Different tree species may greatly influence the biogeochemistry of forest ecosystems due to differences in nutrient uptake from the soil, litter chemistry, root activity, canopy interception and growth. Tree species composition can also influence the understory vegetation (Mölder et al. 2008), the soil nutrient status (Dijkstra, 2003), the soil acidity (Binkley and Valentine 1991, Reich et al. 2005), the composition and activity of the soil fauna and microflora (Neirynck et al. 2000, Cesarz et al. 2007), and the stocks of organic carbon and exchangeable cations (Guckland et al. 2009). Distinctive differences were found between conifers and hardwood species in affecting ecosystem biochemistry or soil chemistry (Rothe et al. 2002, Augusto et al. 2002), but even among hardwood species, remarkable differences can occur (Nordén 1994). So far, only few generalizations about the influence of tree species in mixtures, or about the interaction between environmental factors and nutritional effects can be supported by empirical studies on the nutrition of mixed-species stands (Rothe and Binkley 2001). Tree nutrition in mixtures commonly matches nutrition in monocultures, but 
other interactions can also occur and this relationship needs to be investigated (Rothe and Binkley 2001).

Natural forest vegetation in Central Europe is unique because of the widespread occurrence of beech forests (Fagus sylvatica L.) and its low tree species diversity compared to temperate zones of other continents. European beech is extraordinary among temperate tree species in forming monospecific stands in most parts of its distribution range. Against the background of climate change, which is expected to result in weather extremes and lower amounts of precipitation in the summer (Schönwiese et al. 2003), silvicultural management is promoting mixed stands consisting of beech and secondary broad-leaved tree species to ensure stable and productive forest stands (BMVEL 2001, Röhrig et al. 2006). In beech forests, management programs aim at increasing the portion of other broad-leaved tree species such as ash (Fraxinus excelsior L.), lime (Tilia spp.), maple (Acer spp.), and hornbeam (Carpinus betulus L.).

We sampled data from a range of deciduous tree species along an increasing tree diversity gradient to examine the relationship between above-ground nutrient chemistry and tree species diversity. In previous studies, we found on the one hand that the leaf production and the root biomass did not differ significantly between the mixed-species stands and the pure beech stands, although the total above-ground biomass was highest in the latter ones (Jacob et al. 2010, Meinen et al. 2009a). On the other hand, decomposition rates (Jacob et al. 2009), lumbricid abundance (Cesarz et al. 2007), litter quality and stocks of exchangeable $\mathrm{Ca}$ and $\mathrm{Mg}$ (Guckland et al. 2009) were higher in the mixed species stands than in the monospecific stands. On the basis of these results, we hypothesized that (1) total nutrient stocks are highest in monospecific beech stands due to a higher standing biomass in these stands, (2) basal area-related nutrient stocks are higher in the mixed species stands, (3) basal area-related nutrient stocks of beech are higher in the mixed stands, and (4) compared to the beech, nutrient concentrations and basal area-related nutrient stocks are higher in the tree genera that only occur in the mixed stands as leaf litter decomposition and nutrient release rates are increased in these tree species. 


\subsection{Materials and Methods}

\section{Study area}

This study was conducted in mature stands of deciduous forest trees in the Hainich National Park, Thuringia - Germany's largest semi-natural broad-leaved forest covering a total area of 16,000 ha with about 7,500 ha being protected area. All research sites are situated in the north-eastern part of the national park near the village and meteorological station of Weberstedt $\left(51^{\circ} 06^{\prime} \mathrm{N}, 10^{\circ} 31^{\prime} \mathrm{E}\right)$. The mean annual temperature is $7.5^{\circ} \mathrm{C}$ and the mean annual precipitation ranges from $600 \mathrm{~mm}$ to $670 \mathrm{~mm}$. All plots are situated at an elevation of about $350 \mathrm{~m}$ a.s.l. Soils are Luvisols, developed from Pleistocene loess underlain by limestone (Triassic Upper Muschelkalk formation) (FAO 2006). They have a loess cover of at least $60 \mathrm{~cm}$ and the texture of the mineral soil is characterised by high silt contents (Guckland et al. 2009). The area had been used for military training from the 1960s until 1990 and became a national park in December 1997. Before that time, a small-scale mosaic of forest ownership with different forest management systems from coppice with standards to multiple-aged forests has resulted in contiguous tree species-poor and tree species-rich stands (Leuschner et al. 2009).

In April 2005, three stand types differing in the diversity level (DL) of tree taxa were selected: one stand type consisted of European beech (Fagus sylvatica L.) (DL 1); one was mainly characterised by beech, lime (Tilia cordata Mill. and T. platyphyllos Scop.) and ash (Fraxinus excelsior L.) (DL 2); and one stand type was formed by beech, lime, ash, hornbeam (Carpinus betulus L.) and maple (Acer pseudoplatanum L. and A. platanoides L.) as the dominant tree taxa (DL 3). Other tree species like Quercus robur, Quercus petraea, Prunus avium, Ulmus glabra, and Sorbus torminalis are found occasionally in the mixed-species stands (DL 2 and DL 3). At each diversity level (stand type), three plots with a central area of $50 \mathrm{~m} \times 50 \mathrm{~m}$ were fenced to exclude wild boar and game. All plots were comparable regarding slope, physical soil conditions and stand structure. More details about stand structure and soil parameters are shown in Table 1 (but see also Guckland et al. 2009, Jacob et al. 2010). $\mathrm{N}$ inputs from the atmosphere were moderate with $13 \mathrm{~kg} \mathrm{ha}^{-1}$ (Mund 2004).

\section{Sampling and biomass calculation}

Production of leaf and fruit biomass was determined with 15 litter collectors (aperture: 0.29 $\mathrm{m}^{2}$ ) per plot that were arranged at a minimum distance of $2 \mathrm{~m}$ along three transects (five collectors per transect). All collectors had 8-mm holes drilled through the bottom to allow water drainage from the litter collector. Leaf litter was sampled every two to three weeks during September to December 2005 - 2007 and, additionally, once in spring and once in late summer of 2006. From all samples, leaves, twigs, fruits and flowers were assigned to the 
different tree species, oven-dried at $70{ }^{\circ} \mathrm{C}$ for $48 \mathrm{~h}$, and weighed. Tilia cordata and $T$. platyphyllos were considered one taxon as they hybridize and could not be separated into species.

From July 30 to August 1, 2006, samples of leaves from the upper and lower canopy were taken from five individual trees of six main tree species on one plot per DL. The leaves were collected from six branches per tree ( 3 branches from the upper and 3 from the lower canopy, each with about 15 leaves) by tree climbers using a two-rope climbing system. In total, 50 trees were investigated (Fagus sylvatica at DL 1; Fagus, Fraxinus excelsior, Tilia sp. at DL 2; Fagus, Fraxinus, Tilia, Carpinus betulus, Acer platanoides and Acer pseudoplatanus at DL 3).

Table 1: Stand characteristics and soil properties $(0-30 \mathrm{~cm})$ of the three investigated diversity levels. Given are means \pm 1 SD ( $n=3$ plots per diversity level). Different lower-case letters indicate significant differences between stands

DL 1 DL $2 \quad$ DL 3

\section{Stand characteristics}

Shannon index H' (tree genera, basal area)

Basal area $\left(\mathrm{m}^{2} \mathrm{ha}^{-1}\right)$

$\begin{array}{ccc}0.22 \pm 0.19 \mathrm{c} & 1.02 \pm 0.09 \mathrm{~b} & 1.44 \pm 0.07 \mathrm{a} \\ 41 \pm 4.9 \mathrm{a} & 39 \pm 6.4 \mathrm{a} & 36 \pm 4.2 \mathrm{a} \\ 148 \pm 43 \mathrm{a} & 85 \pm 11.3 \mathrm{~b} & 100 \pm 14.6 \mathrm{ab} \\ 35.7 \pm 2.6 \mathrm{a} & 28.7 \pm 1.1 \mathrm{~b} & 26.7 \pm 0.7 \mathrm{~b} \\ 6.4 \pm 0.5 \mathrm{a} & 6.9 \pm 0.5 \mathrm{a} & 7.1 \pm 0.9 \mathrm{a}\end{array}$

Mean age of canopy trees $\left(\mathrm{yr}^{-1}\right)$

Mean tree height ${ }^{a)}(\mathrm{m})$

$6.4 \pm 0.5 \mathrm{a} \quad 6.9 \pm 0.5 \mathrm{a} \quad 7.1 \pm 0.9 \mathrm{a}$

Soil properties ${ }^{\text {b) }}$

Humus type ${ }^{\text {c) }}$

Soil texture (sand/silt/clay) (\%)

F-Mull L-Mull L-Mull

3/82/15 3/72/25 2/68/30

$\mathrm{pH}\left(\mathrm{H}_{2} \mathrm{O}\right)$

$4.3 \pm 0.2 \mathrm{~b} \quad 4.8 \pm 1.2 \mathrm{a} \quad 5.7 \pm 1.1 \mathrm{a}$

Base saturation (\%)

Cation exchange capacity $\left(\mathrm{mmol}_{\mathrm{c}} \mathrm{kg}^{-1}\right)$

$15.9 \pm 2.6 \mathrm{~b} \quad 84.4 \pm 10.6 \mathrm{a} \quad 93.9 \pm 8.5 \mathrm{a}$

$65.2 \pm 6.6 \mathrm{~b} \quad 112.5 \pm 10.6 \mathrm{a} \quad 159.6 \pm 8.8 \mathrm{a}$

\footnotetext{
a) dominant \& co-dominant trees, class 1 and 2 after Kraft 1884

b) data from Guckland et al. 2009

c) according to the German classification system (Ad-hoc-AG Boden 2005)
}

Concomitantly with the leaf harvest from the canopies, samples of stem wood cores and stem bark were taken at a height of $1.3 \mathrm{~m}$ with a $5 \mathrm{~mm}$ increment corer (Suunto). In total, 140 wood and bark samples were collected from nine plots, with 5 replicates per tree species, including all trees from which canopy leaves were sampled. Acer pseudoplatanus and Acer platanoides are represented with only 10 samples at DL 3 as they occur on only two plots of this DL. 
Species-specific allometric biomass equations were used to calculate above-ground woody biomass of the trees (c.f. Jacob et al. 2010). Biomass of stem bark and branches was estimated with the program SILVA 2.1 (Meschederu 1997). Leaf biomass was derived from litter sampling. The nutrient stocks of the different tree compartments were computed by multiplying biomass with nutrient concentration. Nutrient concentrations of branches were not available. Therefore, we calculated stem wood concentration times branch biomass to obtain branch nutrient stocks. However, this approach can only be an approximation as branch nutrient concentrations usually increase with decreasing diameter and are higher than those of stem wood (André and Ponette 2003, Augusto et al 2000). Stand nutrient stocks were computed as the sum of nutrient stocks of all nutrient compartments.

\section{Chemical analyses}

Total $\mathrm{C}$ and $\mathrm{N}$ contents were determined in pulverized leaf, fruit, wood, and bark material by an automated $\mathrm{C}$ and $\mathrm{N}$ analyzer (Heraeus Elementar Vario EL, Hanau, Germany). The concentrations of $\mathrm{Ca}, \mathrm{K}$ and $\mathrm{Mg}$ in green leaves, fruits, leaf litter, stem wood and stem bark were analyzed by ICP-AES (Spectro, Kleve, Germany) after pressure digestion (10 h, 180 ${ }^{\circ} \mathrm{C}$ ) with $65 \% \mathrm{HNO}_{3}$. Beech fruits were analysed in equal amounts of nuts and capsules per sample.

Soil $\mathrm{pH}$ was measured in $1 \mathrm{M} \mathrm{KCl}$. Organic $\mathrm{C}(\mathrm{SOC})$ and total $\mathrm{N}\left(\mathrm{N}_{\mathrm{t}}\right)$ contents of soil and forest floor samples were determined by an automated $\mathrm{C}$ and $\mathrm{N}$ analyzer (Heraeus Elementar Vario EL, Hanau, Germany) after grinding the samples (all samples were free of carbonates). Cation exchange capacity (CEC) of mineral soil samples were calculated as the equivalent sum of the exchangeable $\mathrm{Na}, \mathrm{K}, \mathrm{Ca}, \mathrm{Mg}, \mathrm{Mn}, \mathrm{Fe}, \mathrm{Al}$ and $\mathrm{H}$ ions after leaching the soil samples with $100 \mathrm{ml}$ of $1 \mathrm{M}$ ammonium chloride $\left(\mathrm{NH}_{4} \mathrm{Cl}\right)$. Base saturation was defined as the sum of base cation equivalents ( $\mathrm{Na}, \mathrm{K}, \mathrm{Ca}$ and $\mathrm{Mg}$ ) in percent of $\mathrm{CEC}$ (Guckland et al. 2009).

\section{Statistical analyses}

Statistical data analysis was conducted using the software R, version 2.9.1 (R Development Core Team, Vienna, Austria, 2008) with the package nparcomp. We used a non-parametric multiple comparison procedure after Hothorn et al. (2008), implemented for Tukey-contrasts, to detect differences between the three diversity levels and between tree species. Significance was assumed for two-sided $p$-values $<0.05$ in all cases. 


\subsection{Results}

\section{Nutrient concentrations in tree compartments of different tree species}

We found significant differences between the tree genera for all tree compartments and all nutrients (Table 2). Green leaves of Fagus had significantly lower nutrient concentrations in its foliage than the other tree species. Fraxinus had the highest concentrations of the cations $\mathrm{Ca}, \mathrm{K}, \mathrm{Mg}$ and Tilia exhibited significantly higher $\mathrm{N}$ and $\mathrm{P}$ concentrations. Stem wood nutrient concentrations showed no consistent pattern for the five tree species. Acer and Fraxinus exhibited high concentrations of $\mathrm{K}$ and $\mathrm{Mg}$ and low values of $\mathrm{N}$ and $\mathrm{P}$. Carpinus and Tilia stem wood was rich in $\mathrm{N}, \mathrm{P}$, and $\mathrm{Ca}$ and low in $\mathrm{Mg}$ and $\mathrm{K}$. In the stem bark, Carpinus had significantly higher concentrations of all nutrients (except for $\mathrm{K}$ ) than all other tree species. In contrast, Fraxinus had comparatively low nutrient concentrations in the stem bark, but significantly higher $\mathrm{K}$ values. Very high concentrations of all nutrients were found in Acer fruits. Fruits of Fagus and Carpinus had significantly lower nutrient concentrations.

The nutrient concentrations differed distinctly between the tree compartments (Table 2). In stem wood, all macronutrient concentrations were lowest. Green leaves and fruits exhibited higher concentrations than stem bark and stem wood. The only exception was the $\mathrm{Ca}$ concentration in stem bark, which, in all tree species, was higher than in the other tree compartments.

\section{Nutrient concentrations of Fagus sylvatica along a tree-species diversity gradient}

Except for green leaves and the Ca concentrations in stem wood, Fagus trees showed lower 'base cation' concentrations in the monospecific stands (DL 1) than in the more diverse ones (Table 3). The concentrations of $\mathrm{K}$ and $\mathrm{Mg}$ in stem wood as well as those of $\mathrm{Ca}, \mathrm{K}$, and $\mathrm{Mg}$ in the stem bark were lowest at DL 1. Except for $\mathrm{K}$, the beech trees of DL 2 exhibited significantly higher nutrient concentrations in their fruits than the monospecific stands and, in part, the DL 3 stands. No difference was found in the $\mathrm{N}$ concentrations between the diversity levels in all tree compartments. At DL 1, the concentrations of $\mathrm{P}$ in green leaves were significantly higher, but the $\mathrm{P}$ concentrations in stem wood were lower compared to the other diversity levels (Table 3). 
Table 2: Mean nutrient concentration and standard deviation of five main tree genera ( $\left.\mathrm{mg} \mathrm{g}^{-1} \mathrm{dm}\right)$. All data from 2006 . Different lower-case letters indicate significant differences between tree species within a tree compartment $(p<0.05)$.

\begin{tabular}{|c|c|c|c|c|c|c|c|c|c|c|c|c|c|c|c|c|c|}
\hline & $\mathbf{N}$ & sd & & $\mathbf{P}$ & & sd & & $\mathrm{Ca}$ & sd & & $\mathrm{K}$ & & sd & & Mg & sd & \\
\hline \multicolumn{18}{|c|}{ Fresh leaves } \\
\hline Acer & $22.49 \pm$ & 2.94 & $b$ & 1.53 & \pm & 0.37 & $b$ & $13.12 \pm$ & 3.63 & $b$ & 14.44 & \pm & 4.02 & $a$ & $2.09 \pm$ & 0.70 & $\mathrm{~b}$ \\
\hline Fagus & $22.78 \pm$ & 1.52 & $b$ & 1.29 & \pm & 0.32 & $b$ & $11.06 \pm$ & 4.24 & $\mathrm{~b}$ & 8.50 & \pm & 2.55 & $\mathrm{~b}$ & $1.73 \pm$ & 0.68 & $b$ \\
\hline Fraxinus & $21.79 \pm$ & 2.37 & $\mathrm{~b}$ & 1.52 & \pm & 0.37 & $\mathrm{~b}$ & $17.03 \pm$ & 6.00 & $\mathrm{a}$ & 15.16 & \pm & 3.57 & $a$ & $3.23 \pm$ & 0.88 & $\mathrm{a}$ \\
\hline Carpinus & $20.73 \pm$ & 2.62 & $b$ & 1.44 & \pm & 0.33 & $b$ & $10.58 \pm$ & 2.59 & $\mathrm{~b}$ & 7.75 & \pm & 1.65 & $\mathrm{~b}$ & $2.13 \pm$ & 0.57 & $a b$ \\
\hline Tilia & $26.87 \pm$ & 2.06 & $\mathrm{a}$ & 1.89 & \pm & 0.37 & $\mathrm{a}$ & $13.36 \pm$ & 2.47 & $\mathrm{~b}$ & 14.36 & \pm & 4.61 & $\mathrm{a}$ & $2.02 \pm$ & 0.61 & $\mathrm{~b}$ \\
\hline \multicolumn{18}{|l|}{ Fruits } \\
\hline Acer & $21.32 \pm$ & 4.81 & $\mathrm{a}$ & 2.60 & & 0.59 & $\mathrm{a}$ & $13.37 \pm$ & 2.72 & $\mathrm{a}$ & 10.93 & & 2.11 & $\mathrm{a}$ & $1.77 \pm$ & 0.14 & $\mathrm{a}$ \\
\hline Fagus & $13.91 \pm$ & 3.20 & $b$ & 1.20 & \pm & 0.23 & c & $4.87 \pm$ & 0.79 & $d$ & 6.37 & \pm & 0.74 & $\mathrm{C}$ & $0.92 \pm$ & 0.15 & $d$ \\
\hline Fraxinus & $20.95 \pm$ & 1.41 & $\mathrm{a}$ & 2.13 & \pm & 0.18 & $b$ & $5.96 \pm$ & 0.48 & $\mathrm{c}$ & 8.14 & \pm & 1.29 & $\mathrm{~b}$ & $1.35 \pm$ & 0.17 & $c$ \\
\hline Carpinus & $12.52 \pm$ & 2.20 & bc & 1.05 & \pm & 0.16 & $d$ & $7.81 \pm$ & 0.71 & $b$ & 4.48 & \pm & 0.84 & $d$ & $1.28 \pm$ & 0.21 & $c$ \\
\hline Tilia & $11.62 \pm$ & 3.04 & c & 0.98 & \pm & 0.37 & $d$ & $13.55 \pm$ & 1.71 & $a$ & 4.85 & \pm & 1.34 & $d$ & $1.54 \pm$ & 0.22 & $\mathrm{~b}$ \\
\hline \multicolumn{18}{|c|}{ Stem wood } \\
\hline Acer & $1.11 \pm$ & 0.30 & $b$ & 0.10 & & 0.02 & $\mathrm{bc}$ & $1.41 \pm$ & 0.78 & $\mathrm{a}$ & 1.22 & \pm & 0.69 & $a b$ & $0.31 \pm$ & 0.17 & $\mathrm{a}$ \\
\hline Fagus & $1.21 \pm$ & 0.16 & $b$ & 0.08 & \pm & 0.02 & $c$ & $0.96 \pm$ & 0.33 & $b$ & 1.17 & \pm & 0.39 & $b$ & $0.22 \pm$ & 0.10 & $\mathrm{a}$ \\
\hline Fraxinus & $1.21 \pm$ & 0.15 & $b$ & 0.08 & \pm & 0.03 & c & $0.90 \pm$ & 0.15 & $b$ & 1.39 & \pm & 0.23 & $a$ & $0.21 \pm$ & 0.04 & $a$ \\
\hline Carpinus & $1.60 \pm$ & 0.22 & $\mathrm{a}$ & 0.10 & \pm & 0.02 & $b$ & $1.20 \pm$ & 0.15 & $\mathrm{a}$ & 1.03 & \pm & 0.21 & $\mathrm{~b}$ & $0.14 \pm$ & 0.05 & $b$ \\
\hline Tilia & $1.35 \pm$ & 0.16 & $b$ & 0.13 & \pm & 0.03 & $a$ & $1.16 \pm$ & 0.21 & $a$ & 0.77 & \pm & 0.21 & $\mathrm{C}$ & $0.14 \pm$ & 0.06 & $\mathrm{~b}$ \\
\hline \multicolumn{18}{|c|}{ Stem bark } \\
\hline Acer & $7.25 \pm$ & 1.41 & $a b c$ & 0.49 & & 0.04 & $\mathrm{a}$ & $34.74 \pm$ & 4.81 & $b$ & 3.18 & \pm & 0.19 & $b$ & $0.73 \pm$ & 0.17 & $a b$ \\
\hline Fagus & $6.84 \pm$ & 0.43 & $b$ & 0.31 & \pm & 0.02 & $b$ & $27.49 \pm$ & 3.69 & $\mathrm{C}$ & 2.31 & \pm & 0.28 & $\mathrm{C}$ & $0.56 \pm$ & 0.13 & $c$ \\
\hline Fraxinus & $6.05 \pm$ & 0.77 & c & 0.32 & \pm & 0.02 & $b$ & $23.64 \pm$ & 2.94 & $d$ & 5.52 & \pm & 0.82 & $a$ & $0.62 \pm$ & 0.09 & bc \\
\hline Carpinus & $8.95 \pm$ & 0.81 & $\mathrm{a}$ & 0.41 & \pm & 0.07 & $\mathrm{a}$ & $43.14 \pm$ & 1.99 & $\mathrm{a}$ & 1.99 & \pm & 0.23 & $\mathrm{C}$ & $1.01 \pm$ & 0.15 & $\mathrm{a}$ \\
\hline Tilia & $6.02 \pm$ & 0.40 & c & 0.47 & \pm & 0.07 & $\mathrm{a}$ & $22.81 \pm$ & 4.36 & $\mathrm{~d}$ & 3.54 & \pm & 0.53 & $\mathrm{~b}$ & $0.58 \pm$ & 0.15 & bc \\
\hline
\end{tabular}

\section{Nutrient stocks along a diversity gradient}

Total nutrient stocks did not differ significantly between the three diversity levels (except for $\mathrm{N}$ ), although the biomasses of stem wood, branches and therefore total biomass were significantly higher at DL 1 (Table 4). However, basal area-related nutrient stocks increased with increasing tree species diversity. This holds true for all nutrients and all tree compartments (Table 5).

The stocks of most nutrients exhibited a similar distribution pattern across the individual tree compartments. N, P, K and Mg contents were contained to $40-60 \%$ in stem wood, $10-20 \%$ in branches, 10-20 \% in stem bark, 5-15\% in green leaves, and 1.5-7\% in fruits. Ca stocks were an exception with only $30 \%$ in stem wood, $10 \%$ in branches and $50 \%$ in stem bark (Tables 4, 5). 
Basal area-related $\mathrm{N}$ stocks of Fagus were significantly higher in the stem wood, branches, stem bark, and in the total stocks of the monospecific stand DL 1 than in the mixed stands (Table 6). Green leaves, fruits, and stem bark showed no differences between the diversity levels (except for $\mathrm{N}$ in stem bark). All other nutrients did not show significant differences along the gradient of tree species diversity.

Table 3: Mean annual nutrient concentrations (+/- 1 SD) in different tree compartments of Fagus sylvatica at three diversity levels $(D L)$. Different lower-case letters indicate differences between the $D L(p<0.05)$.

\begin{tabular}{|c|c|c|c|c|c|c|c|c|c|c|}
\hline & $\mathbf{N}$ & sd & $\mathbf{P}$ & sd & $\mathrm{Ca}$ & sd & $\mathbf{K}$ & sd & Mg & sd \\
\hline \multicolumn{11}{|c|}{ Fresh leaves } \\
\hline DL 1 & $23.77 \pm$ & $0.32 \mathrm{a}$ & $1.38 \pm$ & $0.05 \mathrm{a}$ & $10.79 \pm$ & $0.49 \mathrm{a}$ & $8.81 \pm$ & $0.69 a b$ & $1.79 \pm$ & $0.15 \mathrm{a}$ \\
\hline DL 2 & $22.52 \pm$ & $0.47 \mathrm{a}$ & $1.11 \pm$ & $0.03 \mathrm{~b}$ & $9.77 \pm$ & $0.90 \mathrm{a}$ & $7.15 \pm$ & $0.42 \mathrm{~b}$ & $1.59 \pm$ & $0.14 \mathrm{a}$ \\
\hline DL 3 & $23.16 \pm$ & $0.48 a$ & $1.21 \pm$ & $0.17 b$ & $14.39 \pm$ & $2.30 \mathrm{a}$ & $10.00 \pm$ & $1.30 \mathrm{a}$ & $2.04 \pm$ & $0.29 \mathrm{a}$ \\
\hline \multicolumn{11}{|c|}{ Fruits } \\
\hline DL 1 & $11.73 \pm$ & 0.64 b & $1.05 \pm$ & $0.03 \mathrm{~b}$ & $4.04 \pm$ & $0.11 \mathrm{c}$ & $6.16 \pm$ & $0.18 \mathrm{a}$ & $0.80 \pm$ & $0.02 \mathrm{~b}$ \\
\hline DL 2 & $15.62 \pm$ & $0.64 a$ & $1.35 \pm$ & $0.04 \mathrm{a}$ & $5.43 \pm$ & $0.15 \mathrm{a}$ & $6.59 \pm$ & $0.14 a$ & $0.97 \pm$ & $0.02 \mathrm{a}$ \\
\hline DL 3 & $13.82 \pm$ & $0.55 b$ & $1.17 \pm$ & $0.05 \mathrm{~b}$ & $4.94 \pm$ & $0.09 \mathrm{~b}$ & $6.31 \pm$ & $0.17 \mathrm{a}$ & $0.97 \pm$ & $0.04 a$ \\
\hline \multicolumn{11}{|c|}{ Stem wood } \\
\hline DL 1 & $1.27 \pm$ & $0.12 \mathrm{a}$ & $0.07 \pm$ & $0.01 \mathrm{~b}$ & $0.88 \pm$ & $0.07 \mathrm{a}$ & $0.91 \pm$ & $0.19 \mathrm{~b}$ & $0.15 \pm$ & $0.04 \mathrm{~b}$ \\
\hline DL 2 & $1.17 \pm$ & $0.09 \mathrm{a}$ & $0.08 \pm$ & $0.01 \mathrm{ab}$ & $1.10 \pm$ & $0.27 \mathrm{a}$ & $1.32 \pm$ & $0.26 \mathrm{a}$ & $0.25 \pm$ & $0.08 \mathrm{a}$ \\
\hline DL 3 & $1.19 \pm$ & $0.07 \mathrm{a}$ & $0.09 \pm$ & $0.02 a$ & $0.90 \pm$ & $0.16 a$ & $1.27 \pm$ & $0.14 a$ & $0.25 \pm$ & $0.04 a$ \\
\hline \multicolumn{11}{|c|}{ Stem bark } \\
\hline DL 1 & $6.96 \pm$ & $0.18 a$ & $0.31 \pm$ & $0.02 \mathrm{a}$ & $24.73 \pm$ & $0.64 \mathrm{~b}$ & $2.13 \pm$ & $0.05 \mathrm{~b}$ & $0.51 \pm$ & $0.01 \mathrm{~b}$ \\
\hline DL 2 & $6.75 \pm$ & $0.29 \mathrm{a}$ & $0.32 \pm$ & $0.01 \mathrm{a}$ & $30.69 \pm$ & $1.40 \mathrm{a}$ & $2.38 \pm$ & $0.22 \mathrm{ab}$ & $0.47 \pm$ & $0.03 \mathrm{~b}$ \\
\hline DL 3 & $6.81 \pm$ & $0.27 \mathrm{a}$ & $0.31 \pm$ & $0.01 \mathrm{a}$ & $26.83 \pm$ & $2.49 a b$ & $2.47 \pm$ & $0.06 \mathrm{a}$ & $0.78 \pm$ & $0.01 \mathrm{a}$ \\
\hline
\end{tabular}

\section{Nutrient stocks of different tree species}

Fraxinus had significantly higher nutrient stocks in the stem bark and relatively low basal area-related nutrient stocks in the stem wood compared to the other tree species (Table 7). The opposite was true for Fagus: high basal area-related nutrient stocks were found in the stem wood and comparatively low stocks in stem bark and green leaves. Carpinus had large stocks of all nutrients in green leaves. In Tilia, we found significantly lower nutrient stocks in fruits.

The basal area-related nutrient stocks were less variable in the 'storage compartments' stem wood and branches. Species-specific differences increased within the 'productivity compartments' green leaves and fruits for all nutrients. 


\section{Chapter 6}

Table 4: Mean aboveground biomass and nutrient stocks in different tree compartments. $\mathrm{N}=3$ at each diversity level (DL). Different lower-case letters indicate significant differences between the $\mathrm{DL}(\mathrm{p}<0.05)$.

\begin{tabular}{|c|c|c|c|c|c|c|c|c|c|c|c|c|c|c|}
\hline & DL & Biomass & & $\begin{array}{l}\% \text { of } \\
\text { total }\end{array}$ & $\mathbf{N}$ & & $\mathbf{P}$ & & $\mathrm{Ca}$ & & $\mathbf{K}$ & & $\mathrm{Mg}$ & \\
\hline & & $\mathrm{Mg} \mathrm{ha}^{-1}$ & & biomass & & & & & $\mathrm{kg} \mathrm{ha}^{-1}$ & & & & & \\
\hline \multirow[t]{3}{*}{ Stem wood } & 1 & 316 & $\mathrm{a}$ & 70.0 & 401.4 & $\mathrm{a}$ & 21.7 & $a b$ & 281.8 & $\mathrm{a}$ & 286.8 & $\mathrm{a}$ & 47.1 & $a$ \\
\hline & 2 & 228 & $b$ & 69.4 & 269.5 & $\mathrm{~b}$ & 19.0 & $b$ & 245.7 & $a b$ & 281.9 & $\mathrm{a}$ & 51.6 & $\mathrm{a}$ \\
\hline & 3 & 202 & $\mathrm{~b}$ & 68.6 & 265.3 & $b$ & 21.4 & $a$ & 220.7 & $b$ & 213.1 & $a$ & 38.7 & $a$ \\
\hline \multirow[t]{3}{*}{ Branches } & 1 & 114.84 & $\mathrm{a}$ & 25.3 & 145.9 & $\mathrm{a}$ & 7.9 & $a b$ & 102.2 & $\mathrm{a}$ & 104.1 & $\mathrm{a}$ & 17.2 & $a$ \\
\hline & 2 & 78.26 & $b$ & 23.8 & 92.3 & $\mathrm{~b}$ & 6.6 & $\mathrm{~b}$ & 85.1 & $a$ & 96.2 & $a$ & 17.8 & $a$ \\
\hline & 3 & 75.24 & $b$ & 25.4 & 98.7 & $b$ & 7.9 & $a$ & 81.7 & $\mathrm{a}$ & 79.5 & $\mathrm{a}$ & 14.4 & $\mathrm{a}$ \\
\hline \multirow[t]{3}{*}{ Stem bark } & 1 & 14.79 & $\mathrm{a}$ & 3.27 & 102.5 & $\mathrm{a}$ & 4.6 & $\mathrm{a}$ & 363.9 & $\mathrm{a}$ & 32.3 & $b$ & 7.5 & $\mathrm{~b}$ \\
\hline & 2 & 15.22 & $\mathrm{a}$ & 4.62 & 100.1 & $\mathrm{a}$ & 5.1 & $\mathrm{a}$ & 405.8 & $\mathrm{a}$ & 52.2 & $\mathrm{a}$ & 8.0 & $a b$ \\
\hline & 3 & 12.85 & $a$ & 4.33 & 86.4 & $a$ & 4.8 & $a$ & 355.8 & $a$ & 46.8 & $a b$ & 8.4 & $a$ \\
\hline \multirow[t]{3}{*}{ Fresh leaves } & 1 & 3.79 & $a$ & 0.75 & 91.0 & $a$ & 5.4 & $\mathrm{a}$ & 41.3 & c & 35.5 & $\mathrm{a}$ & 6.7 & $\mathrm{~b}$ \\
\hline & 2 & 3.76 & $a$ & 1.14 & 86.4 & $a$ & 4.8 & $a$ & 50.1 & b & 38.5 & $a$ & 8.1 & $a$ \\
\hline & 3 & 3.58 & $\mathrm{a}$ & 1.21 & 79.6 & $a$ & 4.7 & $a$ & 58.1 & a & 45.5 & $a$ & 8.5 & $\mathrm{a}$ \\
\hline \multirow[t]{3}{*}{ Fruits } & 1 & 2.84 & $a b$ & 0.63 & 32.2 & $a$ & 2.8 & $a$ & 11.7 & $a$ & 17.4 & $\mathrm{a}$ & 2.3 & $\mathrm{a}$ \\
\hline & 2 & 2.97 & $a b$ & 0.98 & 48.3 & $a b$ & 4.3 & $a b$ & 17.2 & $\mathrm{a}$ & 20.3 & $a b$ & 3.0 & $\mathrm{a}$ \\
\hline & 3 & 1.31 & $b$ & 0.45 & 18.8 & $\mathrm{~b}$ & 1.7 & $\mathrm{~b}$ & 10.8 & $\mathrm{a}$ & 8.1 & $b$ & 1.8 & $\mathrm{a}$ \\
\hline \multirow{3}{*}{$\begin{array}{l}\text { Total above-ground } \\
\text { biomass }\end{array}$} & 1 & 453 & $\mathbf{a}$ & 100 & 773 & $\mathbf{a}$ & 42 & $\mathbf{a}$ & 801 & $\mathbf{a}$ & 476 & $\mathbf{a}$ & 81 & $\mathbf{a}$ \\
\hline & 2 & 328 & b & 100 & 597 & b & 40 & $\mathbf{a}$ & 804 & $\mathbf{a}$ & 489 & $\mathbf{a}$ & 89 & $\mathbf{a}$ \\
\hline & 3 & 295 & b & 100 & 549 & b & 41 & $\mathbf{a}$ & 727 & $\mathbf{a}$ & 393 & $\mathbf{a}$ & 72 & $\mathbf{a}$ \\
\hline \multirow[t]{3}{*}{ Soil $(0-30 \mathrm{~cm})^{a, b)}$} & 1 & & & & $3252^{c)}$ & b & $862^{\text {b) }}$ & $\mathbf{a}$ & $612^{a)}$ & b & $212^{\mathrm{c})}$ & b & $66^{\text {a) }}$ & c \\
\hline & 2 & & & & $5512^{c)}$ & $\mathbf{a}$ & $1336^{\mathrm{b})}$ & $\mathbf{a}$ & $6653^{a)}$ & $\mathbf{a}$ & $392^{c)}$ & a & $270^{\mathrm{a})}$ & b \\
\hline & 3 & & & & $5771^{c)}$ & $\mathbf{a}$ & $1353^{\text {b) }}$ & $a$ & $9645^{a)}$ & $\mathbf{a}$ & $524^{c)}$ & $\mathbf{a}$ & $864^{\mathrm{a})}$ & $\mathbf{a}$ \\
\hline \multirow[t]{3}{*}{ Total } & 1 & & & & 4025 & b & 904 & $a$ & 1413 & b & 688 & $\mathbf{a}$ & 146 & c \\
\hline & 2 & & & & 6109 & $\mathbf{a}$ & 1376 & $\mathbf{a}$ & 7456 & $\mathbf{a}$ & 881 & $\mathbf{a}$ & 359 & b \\
\hline & 3 & & & & 6319 & $\mathbf{a}$ & 1394 & $\mathbf{a}$ & 10372 & $\mathbf{a}$ & 917 & $\mathbf{a}$ & 936 & $a$ \\
\hline
\end{tabular}

a) data from Guckland et al. 2009, ${ }^{\text {b) }}$ data after Talkner et al. 2009

c) Guckland, personal communication 
Table 5: Mean aboveground biomass and nutrient stocks related to plot basal area (BA) [\%] in different tree compartments. $\mathrm{N}=3$ at each diversity level $(\mathrm{DL})$. Different lower-case letters indicate significant differences between the $D L(p<0.05)$.

\begin{tabular}{|c|c|c|c|c|c|c|c|c|c|c|c|c|c|c|}
\hline & \multirow[t]{2}{*}{ DL } & \multicolumn{2}{|c|}{ Biomass } & \multirow{2}{*}{$\begin{array}{l}\% \text { of total } \\
\text { stand } \\
\text { biomass }\end{array}$} & \multicolumn{2}{|l|}{$\mathbf{N}$} & \multicolumn{4}{|c|}{$\mathrm{Ca}$} & \multicolumn{2}{|l|}{$\mathrm{K}$} & \multicolumn{2}{|l|}{$\mathrm{Mg}$} \\
\hline & & & & & & & & & $\mathrm{ha}^{-1} \mathrm{~m}^{-2}$ & $2_{\text {basal }}$ & & & & \\
\hline \multirow[t]{3}{*}{ Stem wood } & 1 & 4.89 & c & 70.0 & 61.06 & c & 3.79 & c & 45.95 & c & 43.73 & c & 7.12 & $\mathrm{C}$ \\
\hline & 2 & 8.94 & $\mathrm{~b}$ & 69.4 & 110.12 & $b$ & 8.61 & b & 94.78 & $b$ & 104.09 & $b$ & 18.36 & $b$ \\
\hline & 3 & 11.43 & a & 68.6 & 148.16 & a & 11.70 & a & 126.22 & $\mathrm{a}$ & 129.15 & a & 23.76 & $\mathrm{a}$ \\
\hline \multirow[t]{3}{*}{ Branches } & 1 & 1.70 & C & 25.4 & 21.23 & C & 1.30 & c & 15.85 & c & 15.16 & c & 2.48 & $c$ \\
\hline & 2 & 2.98 & $b$ & 23.8 & 36.73 & $b$ & 2.92 & $b$ & 31.94 & b & 34.08 & $\mathrm{~b}$ & 6.09 & $b$ \\
\hline & 3 & 4.12 & $a$ & 25.4 & 53.59 & $a$ & 4.21 & $a$ & 45.55 & a & 46.42 & a & 8.55 & $a$ \\
\hline \multirow[t]{3}{*}{ Stem bark } & 1 & 0.31 & $b$ & 3.27 & 20.86 & $\mathrm{C}$ & 1.09 & $\mathrm{C}$ & 74.86 & c & 8.21 & $b$ & 1.55 & $c$ \\
\hline & 2 & 0.66 & $a$ & 4.62 & 42.12 & $b$ & 2.38 & $b$ & 160.19 & $b$ & 26.10 & a & 3.66 & $b$ \\
\hline & 3 & 0.78 & $a$ & 4.33 & 52.53 & $a$ & 2.95 & $a$ & 232.41 & a & 29.55 & a & 5.63 & $\mathrm{a}$ \\
\hline \multirow[t]{3}{*}{ Fresh leaves } & 1 & 0.06 & $b$ & 0.75 & 14.93 & $\mathrm{~b}$ & 0.93 & $\mathrm{~b}$ & 6.73 & c & 7.00 & $b$ & 1.00 & $\mathrm{~b}$ \\
\hline & 2 & 0.16 & $\mathrm{a}$ & 1.14 & 36.55 & $\mathrm{a}$ & 2.23 & $\mathrm{a}$ & 23.10 & $b$ & 19.26 & a & 3.63 & $\mathrm{a}$ \\
\hline & 3 & 0.20 & $a$ & 1.21 & 36.96 & $a$ & 2.09 & $a$ & 37.23 & $a$ & 20.89 & a & 4.79 & $a$ \\
\hline \multirow[t]{3}{*}{ Fruits } & 1 & 0.04 & $b$ & 0.63 & 5.15 & $\mathrm{~b}$ & 0.46 & $\mathrm{~b}$ & 2.90 & $\mathrm{~b}$ & 2.68 & $\mathrm{~b}$ & 0.43 & $b$ \\
\hline & 2 & 0.08 & $a b$ & 0.98 & 12.79 & $\mathrm{a}$ & 1.18 & $\mathrm{a}$ & 5.38 & $a b$ & 5.32 & $a b$ & 0.88 & $a b$ \\
\hline & 3 & 0.09 & $a$ & 0.45 & 13.29 & $a$ & 1.26 & $\mathrm{a}$ & 7.03 & $\mathrm{a}$ & 5.63 & $\mathrm{a}$ & 1.19 & $\mathrm{a}$ \\
\hline \multirow[t]{3}{*}{ Total } & 1 & 7 & c & & 123 & C & 8 & C & 146 & c & 77 & c & 13 & c \\
\hline & 2 & 13 & b & & 238 & b & 17 & b & 315 & b & 189 & b & 33 & b \\
\hline & 3 & 17 & $\mathbf{a}$ & & 305 & $\mathbf{a}$ & 22 & a & 448 & a & 232 & a & 44 & $\mathbf{a}$ \\
\hline
\end{tabular}

\subsection{Discussion}

In this study on nutrient concentrations and nutrient stocks along a tree diversity gradient, we found significantly increasing basal area-related nutrient stocks with increasing tree species diversity. Nutrient concentrations were generally lower in beech compared to the other deciduous tree species. The nutritional status in the investigated forest stands was good, except for $P$.

\subsubsection{Nutrient status of the investigated forest stands}

The nutrient concentration of green leaves is a good indicator of the actual nutrient supply of forest trees (EC-UN/ECE 1997). In the investigated forest stands, the supply of all nutrients can be expected to be very good as the trees grow on nutrient-rich soils developed from loess over limestone (Guckland et al. 2009). The concentrations of most nutrients were in an intermediate to optimum range when compared to literature data (van den Burg 1990, Krauß 
and Heinsdorf 2005). In the beech, very high concentrations of $\mathrm{Ca}$ and $\mathrm{Mg}$ were found; in Acer, $\mathrm{N}$ and $\mathrm{P}$ concentrations were low to intermediate (van den Burg 1990, EC-UN/ECE 1997). However, not all of the nutrient concentrations were in their optimum range: phosphorus had low concentrations in Fagus leaves and low-to-intermediate concentrations in Carpinus, Acer and Fraxinus leaves according to the classification of van den Burg (1990). Only the $\mathrm{P}$ concentration of Tilia leaves can be assigned to the intermediate range (Van den Burg 1990).

Table 6: Nutrient stocks of Fagus sylvatica related to plot basal area (\%) in different tree compartments at the three diversity levels (DL). Different lower-case letters indicate significant differences between DL $(p<0.05)$.

\begin{tabular}{|c|c|c|c|c|c|c|c|c|c|c|c|}
\hline \multirow{2}{*}{$\begin{array}{l}\text { Tree } \\
\text { compartment } \\
\text { DL }\end{array}$} & \multirow{2}{*}{$\begin{array}{c}\text { Biomass } \\
\left(\mathrm{Mg} \mathrm{ha}^{-1} \mathrm{~m}^{-2} \text { basalarea }\right)\end{array}$} & \multirow{2}{*}{\multicolumn{2}{|c|}{$\mathbf{N}$}} & \multirow[t]{2}{*}{$\mathbf{P}$} & & \multicolumn{2}{|l|}{$\mathrm{Ca}$} & \multicolumn{2}{|l|}{$\mathbf{K}$} & \multicolumn{2}{|l|}{$\mathrm{Mg}$} \\
\hline & & & & & \multicolumn{5}{|c|}{$\mathrm{kg} \mathrm{ha}^{-1} \mathrm{~m}_{\text {basal area }}^{-2}$} & & \\
\hline \multicolumn{12}{|l|}{ Stem wood } \\
\hline 1 & 3.21 & 40.70 & & 2.17 & $a$ & 28.38 & $\mathrm{a}$ & 29.25 & $a$ & 4.81 & b \\
\hline 2 & 2.36 & 27.54 & $b$ & 1.91 & $\mathrm{a}$ & 25.89 & $a b$ & 31.10 & $\mathrm{a}$ & 5.96 & $a$ \\
\hline 3 & 2.28 & 27.17 & $\mathrm{~b}$ & 2.11 & $a$ & 20.54 & $b$ & 28.83 & $a$ & 5.59 & $b$ \\
\hline \multicolumn{12}{|l|}{ Branches } \\
\hline 1 & 1.17 & 14.90 & $a$ & 0.80 & $\mathrm{a}$ & 10.39 & $\mathrm{a}$ & 10.70 & $\mathrm{a}$ & 1.76 & $\mathrm{~b}$ \\
\hline 2 & 0.86 & 10.09 & $\mathrm{~b}$ & 0.70 & $\mathrm{~b}$ & 9.48 & $a b$ & 11.39 & $\mathrm{a}$ & 2.18 & a \\
\hline 3 & 0.84 & 10.00 & $\mathrm{~b}$ & 0.78 & $a b$ & 7.57 & $\mathrm{~b}$ & 10.62 & $a$ & 2.06 & $a b$ \\
\hline \multicolumn{12}{|l|}{ Stem bark } \\
\hline 1 & 0.14 & 9.80 & $\mathrm{a}$ & 0.43 & $\mathrm{a}$ & 34.81 & $\mathrm{a}$ & 3.00 & $\mathrm{a}$ & 0.72 & $\mathrm{a}$ \\
\hline 2 & 0.12 & 8.16 & $a b$ & 0.39 & $\mathrm{a}$ & 37.08 & $\mathrm{a}$ & 2.87 & $\mathrm{a}$ & 0.57 & $\mathrm{a}$ \\
\hline 3 & 0.10 & 7.02 & $\mathrm{~b}$ & 0.32 & $a$ & 27.62 & a & 2.54 & $a$ & 0.80 & $\mathrm{a}$ \\
\hline \multicolumn{12}{|l|}{ Fresh leaves } \\
\hline 1 & 0.03 & 7.92 & $\mathrm{a}$ & 0.46 & $\mathrm{a}$ & 3.60 & $\mathrm{a}$ & 2.94 & $\mathrm{a}$ & 0.60 & $\mathrm{a}$ \\
\hline 2 & 0.04 & 8.04 & $a$ & 0.40 & $\mathrm{a}$ & 3.48 & $\mathrm{a}$ & 2.55 & $\mathrm{a}$ & 0.57 & $\mathrm{a}$ \\
\hline 3 & 0.03 & 6.50 & $a$ & 0.34 & $a$ & 4.04 & $a$ & 2.80 & $a$ & 0.57 & $a$ \\
\hline \multicolumn{12}{|l|}{ Fruits } \\
\hline 1 & 0.03 & 3.48 & $a$ & 0.31 & $a$ & 1.20 & $a$ & 1.83 & $a$ & 0.24 & $a$ \\
\hline 2 & 0.04 & 6.47 & $a$ & 0.56 & $\mathrm{a}$ & 2.25 & $a$ & 2.73 & $a$ & 0.40 & $\mathrm{a}$ \\
\hline 3 & 0.03 & 3.83 & $a$ & 0.32 & $\mathrm{a}$ & 1.37 & $a$ & 1.75 & $a$ & 0.27 & $\mathrm{a}$ \\
\hline \multicolumn{12}{|l|}{ Total } \\
\hline 1 & 4.59 & 77 & $\mathbf{a}$ & 4.2 & $\mathbf{a}$ & 78 & $\mathbf{a}$ & 48 & $\mathbf{a}$ & 8.1 & b \\
\hline 2 & 3.42 & 60 & b & 3.9 & $\mathbf{a}$ & 78 & $\mathbf{a}$ & 51 & $\mathbf{a}$ & 9.7 & $a$ \\
\hline 3 & 3.27 & 55 & b & 3.9 & $\mathbf{a}$ & 61 & $\mathbf{a}$ & 47 & a & 9.3 & $a b$ \\
\hline
\end{tabular}


Table 7: Nutrient stocks and biomass related to plot-specific basal area of five tree genera at the mixed species stands (DL 3). Different lower-case letters indicate significant values between the tree genera $(p<0.05)$.

\begin{tabular}{|c|c|c|c|c|c|c|c|c|c|c|c|}
\hline \multirow[t]{2}{*}{ Tree species } & \multirow{2}{*}{$\frac{\text { Biomass }}{\left(\mathrm{Mg} \mathrm{ha}^{-1}\right)}$} & \multicolumn{2}{|l|}{$\mathbf{N}$} & \multicolumn{2}{|l|}{$\mathbf{P}$} & \multicolumn{2}{|l|}{$\mathrm{Ca}$} & \multicolumn{2}{|l|}{$\mathbf{K}$} & \multicolumn{2}{|l|}{ Mg } \\
\hline & & & & & & $(\mathrm{kg} \mathrm{h}$ & $\left.a^{-1}\right)$ & & & & \\
\hline \multicolumn{12}{|l|}{ Stem wood } \\
\hline Fagus & $2.28 \quad \mathrm{a}$ & 27.17 & $a b$ & 2.11 & a & 20.54 & $a b$ & 28.83 & a & 5.59 & a \\
\hline Fraxinus & $1.77 \mathrm{c}$ & 21.46 & $b$ & 1.60 & b & 15.69 & $\mathrm{~b}$ & 23.89 & $\mathrm{~b}$ & 3.66 & $\mathrm{~b}$ \\
\hline Tilia & $1.98 \mathrm{bc}$ & 27.41 & $a b$ & 2.55 & $\mathrm{a}$ & 23.09 & $\mathrm{a}$ & 15.36 & c & 2.88 & $\mathrm{c}$ \\
\hline Acer & $2.06 \mathrm{abc}$ & 22.95 & $a b$ & 2.01 & $a b$ & 29.06 & $\mathrm{a}$ & 25.15 & $a b c$ & 6.30 & $\mathrm{a}$ \\
\hline Carpinus & $2.10 a b$ & 33.73 & $a$ & 2.18 & $\mathrm{a}$ & 25.15 & $\mathrm{a}$ & 21.75 & $\mathrm{~b}$ & 3.04 & $\mathrm{bc}$ \\
\hline \multicolumn{12}{|l|}{ Branches } \\
\hline Fagus & $0.84 \mathrm{a}$ & 10.00 & $b$ & 0.78 & $a b c$ & 7.57 & $a b$ & 10.62 & a & 2.06 & a \\
\hline Fraxinus & $0.55 a b$ & 6.68 & $a b$ & 0.50 & $\mathrm{c}$ & 4.88 & $\mathrm{~b}$ & 7.44 & $a b c$ & 1.14 & $b$ \\
\hline Tilia & $0.72 \mathrm{~b}$ & 9.98 & $\mathrm{~b}$ & 0.93 & a & 8.40 & $a b$ & 5.59 & c & 1.05 & $c$ \\
\hline Acer & $0.77 \mathrm{ab}$ & 8.52 & $a b$ & 0.75 & $a b c$ & 10.79 & $\mathrm{a}$ & 9.34 & $a b c$ & 2.34 & $a b$ \\
\hline Carpinus & $0.78 a b$ & 12.51 & $a$ & 0.81 & $\mathrm{~b}$ & 9.33 & $\mathrm{a}$ & 8.07 & $\mathrm{~b}$ & 1.13 & $\mathrm{~b}$ \\
\hline \multicolumn{12}{|l|}{ Stem bark } \\
\hline Fagus & $0.103 \mathrm{~b}$ & 7.02 & $c$ & 0.32 & $b$ & 27.62 & $d$ & 2.54 & bc & 0.80 & $b$ \\
\hline Fraxinus & $0.232 \mathrm{a}$ & 13.35 & $\mathrm{a}$ & 0.75 & $\mathrm{a}$ & 58.01 & $\mathrm{a}$ & 13.98 & $\mathrm{a}$ & 1.54 & $\mathrm{a}$ \\
\hline Tilia & 0.106 b & 6.54 & $\mathrm{C}$ & 0.45 & $b$ & 25.04 & d & 3.35 & $\mathrm{~b}$ & 0.61 & $b$ \\
\hline Acer & $0.098 \mathrm{~b}$ & 7.10 & $\mathrm{bc}$ & 0.48 & b & 34.02 & $\mathrm{c}$ & 3.12 & b & 0.71 & $\mathrm{~b}$ \\
\hline Carpinus & $0.103 \mathrm{~b}$ & 9.20 & $\mathrm{~b}$ & 0.42 & $b$ & 44.36 & $b$ & 2.04 & c & 1.04 & $b$ \\
\hline \multicolumn{12}{|l|}{ Fresh leaves } \\
\hline Fagus & $0.028 \mathrm{~b}$ & 6.50 & $a b$ & 0.34 & c & 4.04 & $\mathrm{~b}$ & 2.80 & b & 0.57 & $\mathrm{~b}$ \\
\hline Fraxinus & $0.036 \mathrm{ab}$ & 7.65 & $a b$ & 0.43 & c & 6.82 & $\mathrm{a}$ & 6.21 & $a$ & 1.26 & $a b$ \\
\hline Tilia & $0.033 \mathrm{~b}$ & 8.85 & $\mathrm{~b}$ & 0.54 & $b$ & 4.17 & $\mathrm{~b}$ & 4.81 & $\mathrm{a}$ & 0.70 & $\mathrm{~b}$ \\
\hline Acer & $0.030 \mathrm{~b}$ & 6.72 & $c$ & 0.41 & c & 4.17 & $b$ & 4.47 & a & 0.63 & $b$ \\
\hline Carpinus & $0.052 \mathrm{a}$ & 11.32 & $\mathrm{a}$ & 0.63 & $\mathrm{a}$ & 6.01 & $\mathrm{a}$ & 4.35 & a & 1.29 & $\mathrm{a}$ \\
\hline \multicolumn{12}{|l|}{ Fruits } \\
\hline Fagus & $0.028 a$ & 3.83 & $\mathrm{a}$ & 0.32 & a & 1.37 & $a b$ & 1.75 & a & 0.27 & $a b c$ \\
\hline Fraxinus & $0.010 \mathrm{~b}$ & 2.10 & $a b$ & 0.22 & $\mathrm{a}$ & 0.59 & $\mathrm{~b}$ & 0.79 & $a b$ & 0.15 & $a b c$ \\
\hline Tilia & 0.007 b & 0.76 & $b$ & 0.06 & $b$ & 0.92 & $b$ & 0.30 & $b$ & 0.11 & $\mathrm{c}$ \\
\hline Acer & $0.011 b$ & 2.29 & $\mathrm{a}$ & 0.28 & $\mathrm{a}$ & 1.45 & $a b$ & 1.19 & $\mathrm{a}$ & 0.20 & $b$ \\
\hline Carpinus & $0.027 \mathrm{a}$ & 3.42 & $a$ & 0.29 & $a$ & 2.13 & $a$ & 1.22 & a & 0.35 & $a$ \\
\hline \multicolumn{12}{|l|}{ Total } \\
\hline Fagus & $3.27 \mathrm{a}$ & 55 & b & 3.9 & $a b$ & 61 & b & 47 & $a b$ & 9.3 & a \\
\hline Fraxinus & $2.61 \mathrm{~b}$ & 51 & $a b$ & 3.5 & b & 86 & $\mathbf{a}$ & 52 & $\mathbf{a}$ & 7.7 & b \\
\hline Tilia & $2.85 \mathrm{~b}$ & 54 & b & 4.5 & $\mathbf{a}$ & 62 & C & 29 & d & 5.3 & C \\
\hline Acer & $2.97 a b$ & 48 & $a b$ & 3.9 & $a b$ & 79 & $a b$ & 43 & $a b c$ & 10.2 & $a b$ \\
\hline Carpinus & $3.07 \mathrm{ab}$ & 70 & $\mathbf{a}$ & 4.3 & $a b$ & 87 & $a$ & 37 & C & 6.8 & bc \\
\hline
\end{tabular}


Overall, the highest foliar nutrient concentrations were measured in Tilia and Fraxinus, and were similar to data published in other studies on deciduous tree species (Hagen-Thorn et al. 2004, Hagemeier 2002). In particular, high N concentrations were found in Tilia and Carpinus compared to Fagus, Quercus and Betula (Hagemeier 2002). Tilia and Carpinus also were the tree species with the highest leaf area-related $\mathrm{N}$ concentrations in the sun leaves compared to shade leaves of the same species (Hagemeier 2002). With regard to the $\mathrm{N}$ concentrations, we found no distinct difference between sun and shade leaves of all tree species occurring at different diversity levels. Compared to other deciduous forest tree species, beech exhibited low or even the lowest foliar nutrient concentrations on different types of soil (sandy soils, Hagen-Thorn et al. 2004, Hagemeier 2002; eutric Cambisols, Hagen-Thorn et al. 2004; Luvisols, this study).

\subsubsection{Nutrient concentrations in different tree compartments}

In the investigated forest stands, differences between species in the nutrient concentrations of the stem wood only partly corresponded to the differences in foliar concentrations. Stem wood (sapwood and heartwood) generally has lower nutrient concentrations than all other tree compartments (Jacobsen et al. 2003, Augusto et al. 2000). In our study, the stem wood concentrations of all nutrients represented the integrated inter-specific differences across heart- and sapwood at dbh level. The formation of heartwood and the possible differences between species in nutrient resorption from senescing sapwood may strongly influence the total nutrient content of the sampled stem wood core (Augusto and Bert 2005, Meerts 2002). In the beech, we found significantly lower concentrations of most elements in the stem wood of the monospecific stands. This might be due to the elevated tree height and tree age of the beech trees in the pure stands or to a lower nutrient availability in the soils of these stands (Guckland et al. 2009) compared to beech trees in the DL 3 stands. The P and base cation concentrations of sun and shade leaves were correlated with the tree diversity, whereas the $\mathrm{N}$ concentrations were similar on all plots and diversity levels.

The Ca concentrations of the stem bark were exceptionally high in all tree species. This result can be explained by weathering of the calcareous bedrock. High values were also found in other studies on a range of soils, with Ca concentrations in oak stem bark of about 30 to 50 times higher than in the sapwood of trees growing on podzol to dystrochrept soil (André and Ponette 2003, Whittaker et al 1979), and about 20-30 $\mathrm{mg} \mathrm{g}^{-1}$ on fertilized cambic podzols and dystric cambisols in Fagus sylvatica in southern Sweden (Jönsson 2000). In our study, Fagus sylvatica showed significantly higher Ca concentrations in the stem bark with increasing tree species diversity and increasing exchangeable Ca stocks in the soil.

As hypothesized, most nutrient concentrations of beech were lower compared to other genera that only occurred in the mixed species stands. 


\subsubsection{Are nutrient stocks higher in the monospecific stands?}

For most nutrients, we could not confirm our first hypothesis that nutrient stocks are highest in the monospecific stands. We expected the absolute nutrient stocks generally to be higher in these stands due to their significantly higher biomass (Jacob et al. 2010). This was not true for the $\mathrm{Ca}, \mathrm{Mg}, \mathrm{K}$ and $\mathrm{P}$ stocks as they did not show any significant differences between the forest stands. However, there was one exception: the $N$ stocks were significantly higher in the pure beech stands compared to the mixed species stands.

The finding that the total nutrient stocks of $\mathrm{Ca}, \mathrm{Mg}, \mathrm{K}$ and $\mathrm{P}$ were similar at all diversity levels was due to (1) higher nutrient concentrations $(P, K, M g)$ in the stem wood of beech trees in the mixed species stands compared to beech growing in monospecific stands and (2) higher nutrient concentration of most tree species occurring only in the mixed species stands compared to the beech.

The higher nutrient concentrations in beech stem wood in the mixed species stands can be explained by higher nutrient stocks in the soil. In a previous study, Guckland et al. (2009) found that deciduous tree species diversity along a gradient of beech abundance positively influenced the stocks of $\mathrm{Ca}, \mathrm{Mg}$ and organic carbon in the upper $30 \mathrm{~cm}$ of the mineral soil. The soils of DL1 stands had a lower effective cation exchange capacity and base saturation than those of DL2 and DL3 stands. Hence, the trees could take up more 'base' cations in the mixed species stands than in the pure beech stands and this in turn resulted in higher contents of base cations in stands with higher tree species diversity. The P stocks in the soil did not differ significantly between the forest stands but the stock of organic $P$ was significantly higher in the mixed species stands. This might explain the higher $\mathrm{P}$ concentrations in the stem wood of the beech in the mixed species stands (Talkner et al. 2009).

The higher total $\mathrm{N}$ stocks (sum of stem wood, branches, stem bark, green leaves and fruits) in the pure beech stands can be related to the significantly higher biomass of the tree compartments at DL 1 . Stem wood and branches had significantly higher biomasses and N stocks in the pure stands, whereas $N$ stocks of green leaves and stem bark were similar at all diversity levels. We therefore can conclude that stem wood biomass exerts the largest effect on the total nutrient stocks. In contrast to the concentrations of $\mathrm{P}, \mathrm{Mg}$ and $\mathrm{K}$, we did not find higher $\mathrm{N}$ concentrations in the stem wood of the beech in the mixed species stands compared to the pure beech stands. In most terrestrial ecosystems, an increase in N supply will result in increased biomass production rather than in $\mathrm{N}$ accumulation in structural compartments of the plants (Jacobsen et al. 2003). However, in previous studies we found significantly higher biomass and wood productivity in the pure beech stands compared to the mixed stands (Jacob et al. 2010). This could be due to the species-specific trait of beech to 


\section{Chapter 6}

produce comparably more wood than leaf biomass. This reverse was true for Tilia - one of the main tree species in the mixed species stands (Jacob et al. 2010).

\subsubsection{Do nutrient stocks increase along the tree diversity gradient?}

Contrary to our third hypothesis, basal area-related nutrient stocks in the beech did not differ significantly between diversity levels for most nutrients and tree compartments. In the beechdominated stands, the basal area-related $\mathrm{N}$ stocks are the only nutrient stocks that were significantly higher than in the mixed-species stands.

We could confirm our hypothesis by finding an increase in basal area-related nutrient stocks from pure beech stands to mixed species forest stands for all nutrients and in all tree compartments.

In theory, the relatively higher nutrient stocks in mixed species stands could be due to spatial niche complementarity of resource use in the rhizosphere by means of species-specific architecture of the root system and, consequently, differences among species in the root distribution in the soil. This might result in a higher nutrient flux into the trees in the mixed stands than in the beech-dominated stands. However, Meinen et al. (2009b) found no indication of a vertical or horizontal niche-partitioning of tree roots of the different tree species in the mixed compared to monospecific stands.

\section{Acknowledgements}

We would like to thank the ,Deutsche Forschungsgemeinschaft' (DFG) for funding of the Graduiertenkolleg 1086. We thank Helmut Schwengels (Zweigwerk - Baumpflege) for his professional assistance with climbing our trees and collecting the fresh leaf samples. Valuable help with the laboratory work was provided by Alena Vacátková, Nicolai Brock, Hawa Kamara, Johanna Ropertz, and Alexander Kraft. 


\subsection{References}

Ad-hoc-Arbeitsgruppe Boden (2005) Bodenkundliche Kartieranleitung. Schweizerbart'sche Verlagsbuchhandlung, Stuttgart

André F, Ponette Q, 2003. Comparison of biomass and nutrient content between oak (Quercus petraea) and hornbeam (Carpinus betulus) trees in a coppice-with-standards stand in Chimay (Belgium). Ann. For. Sci 60, 489-502.

Augusto L, Bert D, 2005. Estimating stemwood nutrient concentration with an increment borer: a potential source of error. Forestry 78,451-455.

Augusto, L, Ranger J, Binkley D, Rothe A, 2002. Impact of several common tree species of European temperate forests on soil fertility. Ann. For. Sci. 59, 233-253.

Augusto L, Ranger J, Ponette Q, Rapp M, 2000. Relationship between forest tree species, stand production and stand nutrient amount. Ann. For. Sci. 57, 313-324.

Binkley D, Valentine D, 1991. Fifty-year biogeochemical effects of green ash, white pine and Norway spruce in a replicated experiment. For. Ecol. Manage. 40, 13-25.

BMVEL (Bundesministerium für Verbraucherschutz, Ernährung und Landwirtschaft) (Ed.), 2001. Gesamtwaldbericht der Bundesregierung. BMVEL, Bonn.

Cesarz S, Fahrenholz N, Migge-Kleian S, Platner C, Schaefer M, 2007. Earthworm communities in relation to tree diversity in a deciduous forest. European Journal of Soil Biologie 43, S61-S67

Dijkstra FA, 2003. Calcium mineralization in the forest floor and surface soil beneath different tree species in the northeastern US. For. Ecol. Manage. 175, 185-194.

EC-UN/ECE, Stefan K, Fürst A, Hacker R, Bartels U, 1997. Forest Foliar Condition in Europe - Results of large-scale foliar chemistry surveys 1995, EC,UN/ECE, 207 pp.

FAO, ISRIC, ISSS World Reference Base for Soil Resources 2006. Report No. 103, World Soil Resources Reports, Rome

Guckland A, Jacob M, Flessa H, Thomas FM, Leuschner C, 2009. Acidity, nutrient stocks, and organic-matter content in soils of a temperate deciduous forest with different abundance of European beech (Fagus sylvatica L.). J Plant Nutr Soil Sci 172:500-511 
Chapter 6

Hagemeier M, 2002. Funktionale Kronenarchitektur mitteleuropäischer Baumarten am Beispiel von Hängebirke, Waldkiefer, Traubeneiche, Hainbuche, Winterlinde und Rotbuche. Berlin, Dissertationes Botanicae, Bd. 361

Hagen-Thorn A, Armolaitis K, Callesen I, Stjernquist I, 2004. Macronutrients in tree stems and foliage: a comparative study of six temperate forest species planted at the same sites. Ann For Sci, 61, 489-498.

Hothorn T, Bretz F, Westfall P, 2008. Simultaneous inference in general parametric models. Biometric Journal 50, 346-363

Jacob M, Leuschner C, Thomas FM, 2010. Productivity of temperate broad-leaved forest stands differing in tree species diversity. Ann For Sci (in press)

Jacob M, Weland N, Leuschner C, Schaefer M, Thomas FM, 2009: Nutrient release from decomposing leaf litter of temperate deciduous forest trees along a gradient of increasing tree species diversity. Soil Biology and Biochemistry, 41: 2122-2130

Jacobsen C, Rademacher P, Meesenburg H, Meiwes KJ, 2003. Gehalte chemischer Elemente in Baumkompartimenten. Literaturstudie und Datensammlung. Forschungzentrum Waldökosysteme, Göttingen, B, 69, 81 pp.

Jönsson AM, 2000. Mineral nutrients of beech (Fagus sylvatica) bark in relation to frost sensivity and soil treatments in southern Sweden. Ann For Sci 57, 1-8.

Kraft G., 1884. Beiträge zur Lehre von den Durchforstungen, Schlagstellungen und Lichtungshieben. Klindworth's Verlag, Hannover.

Krauß H-H, Heinsdorf D, 2005. Ernährungsstufen für wichtige Wirtschaftsbaumarten. Beiträge für Forstwirtschaft \& Landschaftsökologie, 39, 172-179.

Leuschner C, Jungkunst $\mathrm{H}$, Fleck S, 2009. Functional role of forest diversity: pros and cons of synthetic stands and across-site comparisons in established forests. Basic and Applied Ecology 10, 1-9.

Meerts $P, 2002$. Mineral nutrient concentrations in sapwood and heartwood: a literature review. Ann. For. Sci. 59, 713-722

Meinen C, Hertel D, Leuschner C, 2009a. Biomass and morphology of fine roots in temperate broad-leaved forests differing in tree species diversity: is there evidence of below-ground overyielding? Oecologia 161:99-111 
Meinen C, Leuschner C, Ryan NT, Hertel D, 2009b. No evidence of spatial root system segregation and elevated fine root biomass in multi-species temperate broad-leaved forests. Trees 23:941-950

Meschederu M, 1997. Bilanzierung von Biomassen, Kohlenstoff und Stickstoffgehalten mit dem Wuchsmodell SILVA 2.1. Jahrestagung der Sektion Ertragskunde (DVFFil1 in Grünberg. 35-44

Mölder A, Bernhardt-Römermann M, Schmidt W (2008) Herb-layer diversity in deciduous forests: Raised by tree richness or beaten by beech? For Ecol Manage 256:272-281

Mund M, 2004. Carbon pools of European beech forests (Fagus sylvatica) under different silvicultural management. Forschungszentrum Waldökosysteme, Reihe A, 189

Neirynck J, Mirtcheva S, Sioen G, Lust N, 2000. Impact of Tilia platyphyllos Scop., Fraxinus excelsior L., Acer pseudoplatanus L., Quercus robur L. and Fagus sylvatica L. on earthworm biomass and physico-chemical properties of a loamy soil. For. Ecol. Manage. 133, 8 275-286.

Nordén, U., 1994. Influence of tree species on acidification and mineral pools in deciduous forest soils of South Sweden. Water Air Soil Poll. 76, 363-381.

Reich PB, Oleksyn J, Modrzynski J, Mrozinski P, Hobbie SE, Eissenstat DM, Chorover J, Chadwick OA, Hale CM, Tjoelker MG (2005) Linking litter calcium, earthworms and soil properties: a common garden test with 14 tree species. Ecol Letters 8:811-818

Röhrig E, Bartsch N, Lüpke B von, 2006. Waldbau auf ökologischer Grundlage. Ulmer, Stuttgart

Rothe A, Binkley D, 2001. Nutritional interactions in mixed species forests: a synthesis. Can. J. For. Res. 31, 1855-1870.

Rothe A, Kreutzer K, Küchenhoff H, 2002. Influence of tree species composition on soil and soil solution properties in two mixed spruce-beech stands with contrasting history in Southern Germany. Plant Soil 240, 47-56.

Schönwiese CD, Bader S, Böhm R, Claussen M, Cubasch U, Fischer H, Gärtner U, GraßI H, Rahmstorf S, Südermann J , Claussen M, Kromp-Kolb H, Richner H, 2003 . Klimastatement 2003 der Deutschen Meteorologischen Gesellschaft (DMG), der Österreichischen Gesellschaft für Meteorologie (ÖGM) und der Schweizerischen 
Chapter 6

Gesellschaft für Meteorologie (SGM).

http://www.dMgev.de/gesellschaft/aktivtaeten/pdf//limastatement_2003

Talkner U, Jansen M, Beese FO, 2009. Soils phosphorus status and turnover in centralEuropean beech forest ecosystems with differing tree species diversity. European Journal of Soil Science 60: 338-346.

Van den Burg J, 1990. Foliar analysis for determination of tree nutrient status - a compilation of literature data. 2. Literature 1985-1989. 'De Dorschkamp', Institute for Forestry and Urban Ecology Wageningen, the Netherlands Rapport 591, 220 pp.

Whittaker RH, Likens GE, Bormann FH, Easton JS, Siccama TG, 1979. The Hubbard Brook ecosystem study: Forest nutrient cycling an element behavior. Ecology 60, 203-220. 


\section{Chapter}

7

Synopsis 


\subsection{Differ monospecific stands from mixed species stands in ecosystem}

\section{functions?}

\section{Biomass and productivity}

Above-ground biomass decreased significantly with increasing Shannon diversity of the tree layer $\left(200-480 \mathrm{Mg} \mathrm{ha}^{-1}\right)$. Similar results were obtained in a variety of unmanaged forest stands in the Czech Republic, Poland and Slovakia with one to eight tree species, within a range of above-ground biomass (169 - $536 \mathrm{Mg} \mathrm{ha}^{-1}$ ) (Szwagrzyk and Gazda 2007).

In this study, total above-ground production did not differ significantly between the different forest stands, but exhibited a decreasing tendency with decreasing beech abundance (9.0, 8.5 and 7.1 Mg ha-1). Leaf production and LAl (leaf area index) were comparable in all investigated forest stands. We observed higher wood production than leaf production in the monospecific stands. These findings are in contrast of synthetic grasslands, where an increase in biomass production with increasing plant diversity has been observed in many studies (e.g. Tilman et al. 1997, Hector et al. 1999, Caldeira et al. 2001, van Ruijven and Berendse 2003, Roscher et al. 2005, Hooper et al. 2005). The diversity-productivity relationship in forests seems to be much more ambiguous, field studies revealed either no differences (Vilà et al. 2003, this study), a significant increase of wood production with increasing tree species diversity (Vilà et al. 2007) or a range from decrease to increase of mixed stands, compared to monospecies stands (e.g. Pretzsch 2005).

We found no evidence of complementary resource use associated with above-ground biomass production (see Chapter 2). These findings suggest that above-ground net primary production is more under the control of climate and edaphic factors than dependent on tree species diversity. Furthermore, characteristic physiological, morphological and architectural traits, which control productivity, seem to be more influential than the mere number of species present.

\section{Leaf litter decomposition and nutrient release}

We could confirm the hypothesis that in the mixed species stands, leaf litter and lignin decomposition rates are higher than in pure beech stands. Correspondingly, rates of nutrient release from the litter mixtures were significantly higher in the highly diverse DL 3 stands. Annual decomposition rate constants $\mathrm{k}$ of the litter mixtures were similar to literature data of central-European tree species (e.g. Irmler 2000, Hobbie et al. 2006, Seastedt 1984, Schaefer 1990). For all DL and tree species, the litter decomposition rates were positively correlated with the initial $\mathrm{N}$ and $\mathrm{Ca}$ concentrations of the litter, Shannon index of tree genera and crown area, soil pH and macro- and mesofauna abundance and negatively, with the initial $\mathrm{C}: \mathrm{N}$ ratio (which explained almost $90 \%$ of the total variance), $\mathrm{C}: \mathrm{P}$, lignin: $\mathrm{N}$, and the thickness of the litter layer. We conclude that - besides chemical composition of the litter - the structure of the 
organic surface layer and the associated meso- and macrofauna abundance, influenced litter decomposition rates.

Higher decomposition and nutrient release rates indicated faster nutrient cycling in the mixed species stands. However, basal area-related productivity is not higher in the mixed than in the pure stands. Hence, along the investigated gradient of tree species diversity, productivity seems to be unaffected by current litter decomposition rates. In contrast, high rates of litter decomposition may be essential for sustaining productivity and nutrient storage of the stands with higher tree species diversity.

\section{Nutrient stocks}

Our study revealed higher basal area-related nutrient storage of $\mathrm{K}, \mathrm{Mg}, \mathrm{Ca}, \mathrm{N}$, and $\mathrm{P}$ in mixed species stands compared to monospecific stands. Absolute total nutrient stocks did not differ significantly between the forest stands (except for nitrogen). This was surprising, as total biomass was significantly higher in the beech stands (factor 1.5 compared to the mixed species stands) and nutrient concentrations varied in an expected range. Consequently, basal area-related nutrient stocks are higher in the mixed species forest stands. The latter applies for all nutrients and in all tree compartments (stem wood, branches, foliage, fruits). As shown before, higher leaf litter decomposition and nutrient release rates, did not result in increased above-ground productivity. We could not confirm the theory, that the relatively higher nutrient stocks in the mixed species stands could be explained by spatial niche complementarity of resource use in the rhizosphere and a higher nutrient flux into the trees. Meinen (2008) found no different vertical or horizontal niche-partitioning of tree roots of different species in mixed compared to monospecific beech stands.

\subsection{Do tree species differ regarding their ecosystem functions?}

\section{Above-ground biomass and productivity}

Most differences observed in above-ground biomass production among forest stands differing in tree species richness could be attributed to species-specific traits or contrasting site conditions (Kerr et al. 1992, Vilà et al. 2003, Pretzsch 2005). We found distinct differences between the main tree species of our study regarding total and seasonal production of biomass (Chapter 2): Fraxinus exhibited the highest wood production of all species (up to $0.6 \mathrm{Mg} \mathrm{ha}^{-1} \mathrm{yr}^{-1} \mathrm{~m}^{-2}$ basal area), and reached $60-80 \%$ of its annual increment in basal area already at the end of June. Stem wood production in Fagus exceeded its leaf mass production and basal area-related stem wood production was higher than in the cooccurring tree species Carpinus, Tilia and Acer. Seasonal growth dynamics of Tilia seemed to be more dependent on the prevailing climatic conditions. The stem wood increment was slow in the cool and moist spring of 2006, but much faster in the warm spring of 2007. In 
Tilia, Carpinus and Acer, leaf production exceeded stem wood production by factors of 4 to 1.5.

However, differential seasonal growth patterns among the species did not result in increased productivity at the plot level compared to the monospecific stands. Tilia, Acer and Carpinus betulus invest more carbon into the production of foliage and, thus, enhance carbon cycling in mixed species stands, whereas the production of stem wood in Fagus trees exceeds leaf production and results in longer carbon storage in plants in monospecific stands. Our data suggest that above-ground net primary production is more under the control of tree specific traits than dependent on tree species diversity.

\section{Influence of litter quality on species-specific litter decomposition and nutrient release}

Fagus leaf litter exhibited slowest decomposition rates $(k=0.5)$ of the investigated tree species, whereas Fraxinus leaf litter decomposed fastest $(k=2)$. After 6 months of exposure, leaf litter decomposition of Tilia and Carpinus ranges between 55 and $70 \%$ (Bocock and Gilbert, 1957, Cornelissen, 1996), and Fraxinus litter decay usually reaches more than $80 \%$ (Bocock et al., 1960, Cornelissen, 1996). This is in accordance with the results of our study, in which a mass loss of $80 \%$ was found at the mixed species stands with significant fractions of Carpinus, Fraxinus and Tilia in the tree species composition.

Generally, slower decomposition rates of beech litter is ascribed to its relatively high C:N ratio of about 40 - 60 compared to the noticeably lower C:N ratios in the litter of ash, hornbeam and lime (Cotrufo et al. 2000; Hättenschwiler and Gasser 2005; Hobbie et al. 2006; Wise and Schaefer 1994). In this study, litter decomposition rates were positively correlated with initial $\mathrm{N}$ concentrations and negatively with the initial $\mathrm{C}: \mathrm{N}, \mathrm{C}: \mathrm{P}$ and lignin:N ratios of the litter. The initial C: $\mathrm{N}$ ratio of the litter explained almost $90 \%$ of the total variance. Our results support the finding that within a particular climatic region, $\mathrm{N}$ concentrations, or ratios of $\mathrm{N}$ to other foliar compounds, belong to the main factors that influence the rates of litter decomposition (Aerts 1997; Cornelissen 1996; Parton et al. 2007).

Nitrogen release patterns from the leaf litter differed between tree species and can also be related to initial $\mathrm{N}$ content in leaves. In Tilia, Fraxinus and Carpinus, we observed an immediate $\mathrm{N}$ release after incubation. However, Fagus, showed typical triphasic pattern of $\mathrm{N}$ leaching, microbial immobilization and mineralization (Berg and McClaugherty, 2008). N immobilization has often been related to initial litter $\mathrm{N}$ concentration, the influence of these values is best explained by the growth of fungal hyphae into the litter and their need for $\mathrm{N}$. Macronutrients other than $\mathrm{N}$ in the litter can influence decomposition as well. We found a positive correlation between litter decomposition rates and initial calcium concentration of the litter, which was observed by other studies (Hobbie et al. 2006). 
In contrast to many other studies and tree species, we found no or only little accumulation of calcium $(\mathrm{Ca})$ in the leaf litter but a fast Ca release from the litter of Tilia, Fraxinus and Acer platanoides. $\mathrm{Ca}$ is known to be part of the structural plant tissue, hence its release is related to the second decomposition phase (Blair, 1988, Laskowski et al., 1995).

In contrast to other studies on temperate forest tree species (Hobbie et al. 2006; Madritch and Cardinale 2007; Osono and Takeda 2005; Sariyildiz 2008), we found no significant correlation between decomposition rates and lignin concentration of the litter. This could be because lignin has not yet passed the second phase of degradation (Berg and McClaugherty 2008; Kalbitz et al. 2006), which starts when the mass loss of litter exceeds a speciesspecific level.

The large differences between the decomposition rates of beech litter and those of litter from the other investigated tree species influenced the decomposition rates of the stand-specific litter mixtures, which were highest at mixed forest stands. In these stands, tree species with low initial $\mathrm{C}: \mathrm{N}$ ratios in their litter (Carpinus betulus, Fraxinus excelsior, Tilia cordata) together formed nearly two thirds of the canopy cover. On the other hand, high fractions of Fagus sylvatica in the canopy cover were connected with lower decomposition rates of total litter and lignin. Thus, the decomposition and also nutrient rates were strongly dependent on the presence or absence of few individual species, but not on leaf litter diversity per se.

\section{Interrelation between soil fauna, leaf litter decomposition and nutrient dynamics}

Comparing the decomposition of different litter mixtures, a large influence of the fauna on decomposition is found, although the effect changed with litter type (e.g. Schädler and Brandl 2005). The positive effects of the soil fauna on decomposition were highest in $\mathrm{N}$ rich and $\mathrm{C}$ poor litter. Higher leaf litter decay rate in mixed species forest stands was probably due to the combined effect of higher earthworm abundance, better litter quality and elevated soil $\mathrm{pH}$ values. The decomposition rate constant k of Tilia, Acer and Carpinus leaf litter as well as of the litter mixtures were positively correlated to earthworm abundance. On the other hand, we found an overall close correlation between the decomposition rate of Fagus sylvatica litter and isopod abundance.

Soil fauna can be effective in reducing nutrient immobilization by accelerating decomposition rates (Anderson, 1973, Staaf 1987, Joergensen, 1991). Soil fauna abundances in our study were correlated with the length of time lag before $\mathrm{N}$ and $\mathrm{P}$ release of almost all tree species studied. Similar findings for $\mathrm{N}$ release in beech showed a positive correlation to earthworm biomass (Irmler 2000). 


\section{Nutrient concentrations and stocks in different tree compartments}

We found the highest foliar concentration in Tilia (N, P, K) and Fraxinus (Ca, K, Mg). These two species differ in leaf $\mathrm{N}$ concentration: linden had the highest $\mathrm{N}$ concentration, ash lower values compared to all tree species. Low $\mathrm{N}$ concentration of ash could be explained with low concentration in petioles, which Hagen-Thorn et al. (2004) found to be less than one third of leaflets. A possible explanation for the high $\mathrm{N}$ contents in lime is its significantly higher $\mathrm{N}$ concentration in sun leaves per leaf area, measured by Hagemeier (2002).

Differences between species foliage nutrient concentrations only partly corresponded to differences in species stem wood concentration. Ash had the highest foliage concentrations of $\mathrm{S}$ and the 'base' cations $(\mathrm{Ca}, \mathrm{K}, \mathrm{Mg}$ ) but showed only relatively high concentrations of $\mathrm{K}$ and $\mathrm{Mg}$ in the stem wood. Lime had highest foliage $\mathrm{N}$ and $\mathrm{P}$ concentration, but in stem wood only $\mathrm{P}$ concentration was significantly higher than in all other tree species.

Beech foliage and leaf litter had the lowest nutrient concentrations compared to the other deciduous tree species. Rather constant $\mathrm{N}$ concentration of beech litter and comparably low concentrations of beech foliage were found in Fagus stands across a soil fertility gradient (Meier et al. 2005), from sandy soils (Hagemeier 2002), eutric cambisols (Hagen-Thorn et al. 2004) and nutrient rich luvisols on loess over limestone (this study).

Ca concentration, which is known to be soil dependent (Jacobsen et al. 2003) accumulated in leaf litter compared to foliage concentration. This finding was confirmed and was similar for all tree species. Stem bark concentration of $\mathrm{Ca}$ were exceptionally high, which can be explained by the calcareous bedrock of our study area. Fraxinus concentrated $67 \%$ of its total $\mathrm{Ca}$ amount in the stem bark. Fraxinus had relatively low basal area-related stem wood and higher stem bark nutrient stocks of all nutrients compared to the other tree species.

The reverse was true for Fagus, the basal area-related nutrient amounts in stem wood were high (Mg reached a maximum with $60 \%$ of the total Mg content stored in stem wood), and comparatively low basal area-related nutrient amounts in stem bark, green leaves and leaf litter.

The variation of all nutrient stocks is within the factors of 1.3 to 1.9 in lime, 1.4 to 3.4 in hornbeam (except P) and 2.5 to 5.75 in beech. This matches to the observation of Augusto et al. (2000), in which literature data show linear relationships between total 'arial biomass' and nutrient content for different species. The basal area-related nutrient stocks were less variable in the 'storage compartments' stem wood and branches and species-specific differences increased for the more easily decomposable 'compartments' fine roots, leaf litter and fruits for all nutrients. 


\subsection{Differences between beech trees in pure compared to mixed species forest stands}

Fagus sylvatica trees produced similar amounts of leaves, fruits or wood independently of tree diversity. At the same time the tendency towards a higher biomass accumulation in the F. sylvatica stands are not due to a better nutrient supply: compared to the mixed forest stands. F. sylvatica stands exhibited significantly lower soil $\mathrm{pH}$ and base saturation, and tended towards lower cation exchange capacity and higher C:N ratios (Guckland et al. 2009). It was suggested that this soil nutrient deficiency of the beech stands were mainly the result of Fagus leaf and root litter effects.

Generally, Fagus leaf litter had high $\mathrm{C}: \mathrm{N}$ ratios and low nutrient concentrations in their foliage, which led to less degradability compared to other tree species. Beech litter had significantly higher $\mathrm{N}, \mathrm{P}, \mathrm{S}$ and lower $\mathrm{Ca}$ and $\mathrm{Mg}$ concentrations in the monospecific forest stands. Annual litter $\mathrm{N}$ input and $\mathrm{N}$ storage in the organic layer and in the mineral soil increased with increasing tree species diversity and decreasing beech abundance (Guckland et al. 2009 and pers. comm.). Litter decomposition of Fagus is enhanced in mixed species stands. Nutrient release rates of $\mathrm{N}$ in beech started earlier and were significantly higher in mixed species stands. Higher beech leaf litter decay rates in mixed species forest stands were probably due to the higher earthworm abundance and elevated soil $\mathrm{pH}$ values.

Significantly lower concentrations of most elements were found in beech stem wood in monospecific stands (except $\mathrm{N}$ and $\mathrm{Ca}$ ). Phosphorus in beech revealed higher concentration in beech stem wood in the mixed stands and high beech foliage concentration in pure stands. P stocks in different tree compartment however, differed only in branches between the diversity levels. Differences in total basal area-related nutrients stocks of $\mathrm{N}, \mathrm{Mg}$ and $\mathrm{S}$ were related to significant differences in nutrient amounts of stem wood and branches.

\subsection{Interactions between tree species and soil parameters}

We found distinct differences in surface soil acidification, stocks of exchangeable base cations and carbon accumulation in the humus layer of temperate broad-leaved mixed forest stands on loess over limestone. Subsoil clay content and differences in litter composition were identified as important factors that contributed to the variability of these soil properties.

Deciduous tree species litter diversity positively influenced stocks of calcium, magnesium and organic carbon in the upper $30 \mathrm{~cm}$ of the mineral soil. This is due to the high nutrient contents in lime, ash, hornbeam and maple leaf litter and the lower leaf litter concentration of base cations within a beech. The soils of the mixed specific beech stands had higher effective cation exchange capacity and base saturation than the beech dominated stands. Elevated Ca concentration in leaf litter, higher Ca release rates of litter and the increased Ca 
nutrient stocks in the soil, were favourable for the abundance of Lumbricus terrestris, which, in turn, was most important for the enhanced decomposition rates of all tree species litter.

Magnesium ( $\mathrm{Mg}$ ) dynamics are comparable to those of $\mathrm{Ca}$. $\mathrm{Mg}$ is a rather mobile element with concentration in leaves strongly dependent on soil properties and bedrock type (Berg and Laskowski, 2006). Talkner et al. (2009) found higher leaching rates of $\mathrm{K}^{+}, \mathrm{Ca}^{2+}$ and $\mathrm{Mg}^{2+}$ from the foliage of mixed species stands. Hence, higher potential of leaf litter for the redistribution of nutrients via litter fall and foliage leaching was suggested to be due to species-specific differences in cation cycling.

The differences in soil clay content between the three diversity levels could explain higher exchangeable $\mathrm{Ca}$ and $\mathrm{Mg}$ stocks in the soil and subsequently, the relatively higher nutrient stocks in trees in the mixed species stands. However, a study conducted with a higher spatial resolution at the investigated stands had shown that beech abundance is clearly the most influencing factor on soil acidification and the nutrient status of the mineral soil (Guckland 2009, Holzwart pers. comm.).

Annual litter $\mathrm{N}$ input and $\mathrm{N}$ storage in the organic layer and in the mineral soil increased with increasing tree species diversity and decreasing beech abundance (Guckland et al. pers. comm.). Litter $N$ turnover is faster in the organic layer (2-13 years) (Guckland et al. pers. comm.) and leaf litter decomposition is much faster at the mixed species stands (Jacob et al. 2009).

Fagus had higher $\mathrm{P}$ concentrations in stem wood and total basal area-related $\mathrm{P}$ stocks in the diverse stands. These stands had higher stocks of organic $P$ and 5 times shorter $P$ turnover times in the organic surface layers, which were explained by Talkner et al. (2009) with differences in tree species litter quality.

Our results suggest that the process of "biological pumping" of base cations, the uptake by tree roots of different tree species in different soil depth, increased with decreasing abundance of beech. In addition, beech abundance influenced litter decomposition rate and nutrient accumulation in the organic surface layer and above-ground biomass. Thus, the conversion of quasi monospecific beech forests to mixed stands of beech with other broadleaved species appeared to increase the intensity of soil-tree cation cycling and as a consequence it can influence the rate of soil acidification and nutrient stocks in the surface soil. The results suggest that at sites that allow production of broadleaf tree species with nutrient-rich, easily decomposable foliage the establishment and promotion of these species is an important silvicultural tool to counteract natural or anthropogenic soil acidification and to maintain soil productivity. 


\subsection{References}

Aerts R, 1997. Climate, leaf litter chemistry and leaf litter decomposition in terrestrial ecosystems: A triangular relationship. Oikos 79: 439-449.

Anderson JM, 1973. The breakdown and decomposition of sweet chestnut (Castanea sativa Mill.) and beech (Fagus sylvatica L.) leaf litter in two deciduous woodland soils. 1. Breakdown, leaching and decomposition. Oecologia 12: 251-274.

Augusto L, Ranger J, Ponette Q, Rapp M, 2000. Relationship between forest tree species, stand production and stand nutrient amount. Ann. For. Sci. 57: 313-324.

Berg B, Laskowski R, 2006. Litter decomposition: A guide to carbon and nutrient turnover. Advances in Ecological Research, Elsevier, Amsterdam, 421 pp.

Berg B, McClaugherty C, 2008. Plant litter - decomposition, humus formation, carbon sequestration. Springer, Berlin, $338 \mathrm{pp}$.

Blair JM, 1988. Nutrient release from decomposing foliar litter of three species with special reference to calcium, magnesium and potassium dynamics. Plant and Soil 110: 49-55.

Bocock KL, Gilbert OJW, 1957. The disappearance of leaf litter under different woodland conditions. Plant and Soil 9: 179-185.

Burschel P, Huss J, 1987. Grundriß des Waldbaus. Paul Parey, Hamburg.

Caldeira MC, Ryel RJ, Lawton JH, Pereira JS, 2001. Mechanisms of positive biodiversityproduction relationships: insights provided by $\delta 13 \mathrm{C}$ analysis in experimental Mediterranean grassland plots. Ecology Letters 4: 439-443.

Cornelissen JHC, 1996. An experimental comparison of leaf decomposition rates in a wide range of temperate plant species and types. The Journal of Ecology 84: 573-582.

Cotrufo MF, Miller M, Zeller B, 2000. Litter decomposition. In: Schulze E-D (Ed.), Carbon and nitrogen cycling in European forest ecosystems, Springer, Berlin, Vol. 142, pp. 276-296.

Guckland A, Jacob M, Flessa H, Thomas FM, Leuschner C, 2009. Acidity, nutrient stocks, and organic-matter content in soils of a temperate deciduous forest with different abundance of European beech (Fagus sylvatica L.). Journal of Plant Nutrition and Soil Science, 172: 500-511. 
Hagemeier M, 2002. Funktionale Kronenarchitektur mitteleuropäischer Baumarten am

Beispiel von Hängebirke, Waldkiefer, Traubeneiche, Hainbuche, Winterlinde und Rotbuche. Berlin, Dissertationes Botanicae, Bd. 361

Hagen-Thorn A, Armolaitis K, Callesen I, Stjernquist I, 2004. Macronutrients in tree stems and foliage: a comparative study of six temperate forest species planted at the same sites. Ann For Sci 61: 489-498.

Hättenschwiler S, Gasser P, 2005. Soil animals alter plant litter diversity effects on decomposition. PNAS 102: 1519-1524.

Hector A, Schmid B, Beierkuhnlein C, Caldeira MC, Diemer M, Dimitrakopoulos PG, Finn JA, Freitas H, Giller PS, Good J, Harris R, Högberg P, Huss-Danell K, Joshi J, Jumpponen A, Körner C, Leadley PW, Loreau M, Minns A, Mulder CPH, O'Donovan G, Otway SJ, Pereira JS, Prinz A, Read DJ, Scherer-Lorenzen M, Schulze ED, Siamantziouras ASD, Spehn EM, Terry AC, Troumbis AY, Woodward FI, Yachi S, Lawton JH, 1999. Plant diversity and productivity experiments in European grasslands. Science 286: 1123-1127.

Hobbie SE, Reich PB, Oleksyn J, Ogdahl M, Zytkowiak R, Hale C, Karolewski P, 2006. Tree species effects on decomposition and forest floor dynamics in a common garden. Ecology 87: 2288-2297.

Hooper DU, Chapin FS, Ewel JJ, Hector A, Inchausti P, Lavorel S, Lawton JH, Lodge DM, Loreau M, Naeem S, Schmid B, Setälä H, Symstad AJ, Vandermeer J, Wardle DA, 2005. Effects of biodiversity on ecosystem functioning: A consensus of current knowledge. Ecological Monographs 75: 3-35.

Irmler $\mathrm{U}, 2000$. Changes in the fauna and its contribution to mass loss and $\mathrm{N}$ release during leaf litter decomposition in two deciduous forests. Pedobiologia 44: 105-118.

Jacob M, Weland N, Platner C, Schaefer M, Leuschner C, Thomas Frank M, 2009. Nutrient release from decomposing leaf litter of temperate deciduous forest trees along a gradient of increasing tree species diversity. Soil Biology \& Biochemistry 41: 2122-2130.

Joergensen RG, 1991. Organic matter and nutrient dynamics of the litter layer on a forest rendzina under beech. Biology and Fertility of Soils 11: 163-169.

Kalbitz K, Kaiser K, Bargholz J, Dardenne P, 2006. Lignin degradation controls the production of dissolved organic matter in decomposing foliar litter. Eur J Soil Sci 57: 504516. 
Kerr G, Nixon CJ, Matthews RW, 1992. Silviculture and yield of mixed-species stands: the UK experience. Cannell MGR, Malcolm DC, Robertson PA, eds. The ecology of mixedspecies stands of trees. Oxford: Blackwell Oxford, p35-51.

Laskowski R, Niklińska M, Maryański M, 1995. The dynamics of chemical elements in forest litter. Ecology 76: 1393-1406.

Madritch MD, Cardinale BJ, 2007. Impacts of tree species diversity on litter decomposition in northern temperate forests of Wisconsin, USA: a multi-site experiment along a latitudinal gradient. Plant Soil 292: 147-159.

Meier IC, Leuschner Ch, Hertel D, 2005. Nutrient return with leaf litter fall in Fagus sylvatica forests across a soil fertility gradient. Plant Ecology 177: 99-112.

Meinen C, 2008. Fine root dynamics in broad-leaved deciduous forest stands differing in tree species diversity. http://webdoc.sub.gwdg.de/diss/2008/meinen/meinen.pdf

Osono T, Takeda H, 2005. Decomposition of organic chemical components in relation to nitrogen dynamics in leaf litter of 14 tree species in a cool temperate forest. Ecol Res 20: 41-49.

Parton,W, Silver WL, Burke IC, Grassens L, Harmon ME, Currie WS, King JY, Adair EC, Brandt LA, Hart SC, Fasth B, 2007. Global-scale similarities in nitrogen release patterns during long-term decomposition. Science 315: 361-364.

Pretzsch H, 2005. Diversity and productivity in forests: evidence from long-term experimental plots. Scherer-Lorenzen M, Körner Ch, Schulze ED, editors. Forest Diversity and Function - Temperate and Boreal Systems. Ecological Studies 176. Berlin: Springer Berlin. p41-64.

Roscher C, Temperton VM, Scherer-Lorenzen M, Schmitz M, Schumacher J, Schmid B, Buchmann N, Weisser WW, Schulze ED, 2005. Overyielding in experimental grassland communities - irrespective of species pool or spatial scale. Ecology Letters 8: 419-429.

Sariyildiz T, 2008. Effects of gap-size classes on long-term litter decomposition rates of beech, oak and chestnut species at high elevations in Northeast Turkey. Ecosystems 11: 841-853.

Schädler M, Brandl R, 2005. Do invertebrate decomposers affect the disappearance rate of litter mixtures? Soil Biology \& Biochemistry 37: 329-337. 


\section{Chapter 7}

Schaefer M, 1990. The soil fauna of a beech forest on limestone: trophic structure and energy budget. Oecologia 82: 128-136.

Seastedt TR, 1984. The role of microarthropods in decomposition and mineralization processes. Annual Review of Entomology 29: 25-46.

Staaf $H, 1987$. Foliage litter turnover and earthworm populations in three beech forests of contrasting soil and vegetation types. Oecologia 72: 58-64.

Szwagrzyk J, Gazda A. 2007. Above-ground standing biomass and tree species diversity in natural stands of Central Europe. Journal of Vegetation Science 18: 555-562.

Talkner U, Jansen M, Beese FO, 2009. Soils phosphorus status and turnover in centralEuropean beech forest ecosystems with differing tree species diversity. European Journal of Soil Science, 60: 338-346.

Tilman D, Knops J, Wedin D, Reich P, Ritchie M, Sieman E, 1997. The influence of functional diversity and composition on ecosystem processes. Science 277: 1300-1302.

Van Ruijven J, Berendse F, 2003. Positive effects of plant species diversity on productivity in the absence of legumes. Ecology Letters 6: 170-175.

Vilà M, Vayreda J, Gracia C, Ibáñez JJ, 2003. Does tree diversity increase wood production in pine forests? Oecologia 135: 299-303.

Vilà M, Vayreda J, Comas L, Ibáñez JJ, Mata T, Obón B, 2007. Species richness and wood production: a positive association in Mediterranean forests. Ecology Letters 10: 241-250.

Wise DH, Schaefer M, 1994. Decomposition of leaf litter in a mull beech forest: comparison between canopy and herbaceous species. Pedobiologia 38: 269-288 


\section{Acknowledgements}

I would like to thank my supervisors, Prof. Dr. Frank Thomas and Prof. Dr. Christoph Leuschner, to whom I owe an interesting research topic, constant support, encouragement, creating an enjoyable work environment and for sharing their enthusiasm about science. Many thanks to the Hainich National Park management, for the permission to conduct research in this most beautiful forest: I would like to thank the DFG (German Research Foundation) for funding.

A wonderful experience was working with all members of the Graduiertenkolleg 1086. Thank you for the great time in forests (and bars) worldwide and for such a harmonious cooperation in data sharing and at the intense field work. A special thank to all members of the Institute of Plant Sciences and for such a friendly working environment, technical support and help in establishing and maintenance of our study plots.

The extensive field work and endless hours of leaf sorting, grounding and lab work, would not have been possible without the help from: Kristina Stapefeld, Dorothea Schölling, Gabi Krisinger, Hawa Kamara, Nickolai Brock, Alena Vacátková, Dr. Nadine Weland, Dr. Inga Mölder, Dr. Andreas Mölder and Sven Jacob.

I want to thank my roommates Dr. Inga Mölder and Dr. Tobias Gebauer for lots of fun, discussions, the aquarium and for saving my plants from severe drought stress. I also want to thank Dr. Catharina Meinen for constant support and for wonderful coffee breaks, Dr. Nadine Weland for her enthusiasm about small little animals and parts of our statistical analysis, and Dr. Sandra Korn and Dr. Jasmin Lendzion for the 'happy hours'. I thank Dr. Hermann Jungkunst for fast reviewing of parts of my thesis, his support and for understanding a geoecologist view about biology.

Without the love and trust of my parents Martin Brauns and Karin Engel-Brauns, I would not be the same person today. Thank you for supporting and believing in me at all times of my life. A very big hug goes to the best sister of all, Bentje Brauns! And to my wonderful granddad, who taught me never to give up laughter and hope. A very special thank for the number one in my life: Sven Jacob. Without his never-ending love, trust, support and constant chocolate supply, I would not have been able to fulfill the dream of my 'first published book' with so much joy. 
- 138 - 


\section{Curriculum vitae}

\section{Personal data}

$\begin{array}{cc}\text { Name } & \text { Mascha Jacob } \\ \text { Date of birth } & \text { 14.05.1978 } \\ \text { Place of birth } & \text { Wilhelmshaven } \\ \text { Nationality } & \text { German }\end{array}$

Education

Apr 05 - Mar $09 \quad$ University of Göttingen, Germany;

PhD study "Biodiversity and Ecology"

PhD degree (Dr. rer nat)

Oct 97 - Aug 04 Technical University of Braunschweig, Germany

Study of Geoecology

Degree obtainded: Diplom - Geoökologin

Jun 88 - Jul 97 Theodor-Heuss-Gymnasium (high school), Göttingen, Germany High school diploma: Abitur. 
Editorial Board for Biodiversity and Ecology Series

Prof. Dr. Hermann Behling, Dept. of Palynology and Climate Dynamics

Prof. Dr. Erwin Bergmeier, Dept. of Vegetation Analysis and Phytodiversity

Prof. Dr. Susanne Bögeholz, Dept. of Didactics of Biology

Prof. Dr. Norbert Elsner, Dept. of Neurobiology

Prof. Dr. Thomas Friedl, Dept. of Experimental Phycology

Prof. Dr. Gerhard Gerold, Dept. of Landscape Ecology

Prof. Dr. S. Robbert Gradstein, Dept. of Systematic Botany

Prof. Dr. Bernd Herrmann, Dept. of Historical Anthropology and Human Ecology

Prof. Dr. Peter Kappeler, Dept. of Sociobiology

Prof. Dr. Christoph Leuschner, Dept. of Plant Ecology and Ecosystems Research

Prof. Dr. Michael Mühlenberg, Dept. of Conservation Biology

Prof. Dr. Joachim Reitner, Dept. of Geobiology

Prof. Dr. Matthias Schaefer, Dept. of Animal Ecology

Prof. Dr. Wolfgang Schmidt, Dept. of Silviculture of the Temperate Zones and Forest

Ecology

Prof. Dr. Henner Simianer, Dept. of Animal Breeding

Prof. Dr. Teja Tscharntke, Dept. of Agroecology

Prof. Dr. Stefan Vidal, Dept. of Agroentomology

Prof. Dr. Rainer Willmann, Dept. of Animal Morphology, Systematics and Evolutionary

Biology

Prof. Dr. Gert Wörheide, Dept. of Geobiology

Members of the Göttingen Centre for Biodiversity and Ecology

Coloured cover images by Göttingen Centre for Biodiversity and Ecology

(legend top to bottom)

1 Mixed deciduous forest in the Hainich region (Central Germany)

2 Different insect taxa on the flowers of a thistle (Cirsium sp.)

3 Glomeris sp., a member of the decomposing soil fauna in forest ecosystems

4 Pleodorina californica (Chlorophyceae), colony-forming freshwater phytoplankton species

5 Grasshopper Tettigonia cantans, distributed from the Pyrenees to Northeastern China

6 Microcebus berthae (Cheirogaleidae), the smallest extant Primate species (Madagascar)

7 Tropical rain forest (Greater Daintree, Australia)

8 Lethocolea glossophylla (Acrobolbaceae), a liverwort of alpine mountain ranges in South America

9 Part of a coral reef in the Red Sea 